\title{
Sporomorphs from the Jackson Group (Upper Eocene) and Adjacent Strata of Mississippi and Western Alabama
}

GEOLOGICAL SURVEY PROFESIONAL PAPER 1084

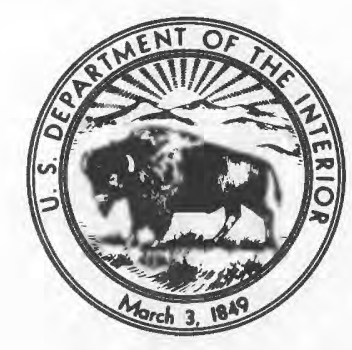





\section{Sporomorphs from the Jackson Group (Upper Eocene) and Adjacent Strata of Mississippi and Western Alabama}

By NORMAN O. FREDERIKSEN

GEOLOGICAL SURVEY PROFESSIONAL PAPER 1084

Taxonomy and stratigraphic ranges

of 174 types of spores

and pollen grains

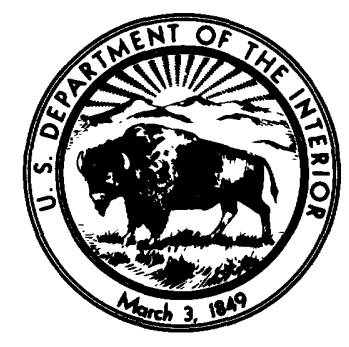

UNITED STATES GOVERNMENT PRINTING OFFICE, WASHINGTON : 1980 


\title{
UNITED STATES DEPARTMENT OF THE INTERIOR
}

\author{
CECIL D. ANDRUS, Secretary
}

\section{GEOLOGICAL SURVEY}

H. William Menard, Director

\footnotetext{
Library of Congress Cataloging in Publication Data

Frederiksen, Norman 0

Sporomorphs from the Jackson Group (upper Eocene) and adjacent strata of Mississippi and western Alabama.

(Geological Survey professional paper; 1084)

Bibliography: $p$.

Supt. of Docs. no.: I 19.16:1084

1. Palynology-Mississippi. 2. Palynology-Alabama. 3. Paleobotany-Eocene. I. Title. II. Series: United States. Geological Survey. Professional paper; 1084.

$78-606149$
}

For sale by the Superintendent of Documents, U.S. Government Printing Office Washington, D.C. 20402

Stock Number 024-001-3258-9 


\section{CONTENTS}

Metric-English equivalents-

Abstract-

Introduction-

Previous studies - -

Acknowledgments -

Stratigraphy

Claiborne Group

Jackson Group-

Vicksburg Group

Jackson Group contacts

Claiborne-Jackson contact

Jackson-Vicksburg contact

Correlation with standard microfossil zones

Palynology

Methods

Sampling and preparation -_

Type specimens

Methods of analysis

Distribution of the sporomorphs

Systemátic descriptions

Genus Laevigatosporites

Laevigatosporites haardtii

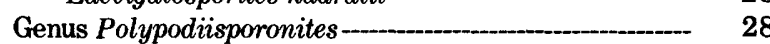

Polypodiisporonites afavus _-_______ 28

Polypodiisporonites alienus _________ 28

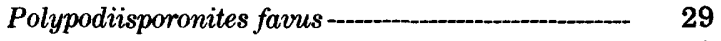

Genus Microfoveolatosporis -______________ 29

Microfoveolatosporis pseudodentata -._-_._- 29

Genus Schizaea Schizaea tenuistriata

Genus Concavisporites -____ $\quad 29$

Concavisporites discites

Genus Cyathea __________ 29

Cyathea? stavensis _.______________ 29

Genus Gleicheniidites-_-_._- 29

Gleicheniidites senonicus _.____________ 29

Genus Lygodium - $\quad 30$

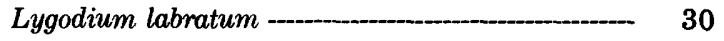

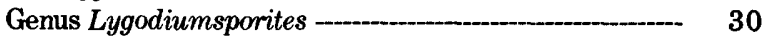
Lygodiumsporites adriennis --_..- 30 Lygodiumsporites? cf. L. adriennis - - 30

Genus Toroisporis ______ 30

Toroisporis aneddenii -___________ 30

Toroisporis longitora -_._._._._._._._. 30

Toroisporis postregularis -___________ 30

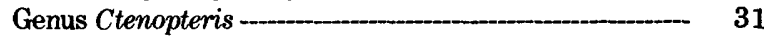

Ctenopteris? elsikii 31

Genus Undulatisporites _____________________ 31

Undulatisporites concavus _-_______ 31

Undulatisporites $\mathrm{sp}$

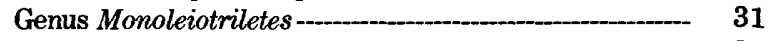

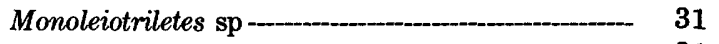

Genus Punctatisporites -________- 31

Punctatisporites microadriennis
Palynology-Continued

Systematic descriptions-Continued

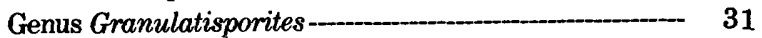

Granulatisporites luteticus-_____________ 31

Genus Osmunda _-_____________ 31

Osmunda primaria _._._._._._._. 31

Genus Pteris -

Pteris dentata -._._________ 32

Genus Bullasporis-_-________ 32

Bullasporis sp-___ 32

Genus Cicatricosisporites

Cicatricosisporites dorogensis -___________ 32

Cicatricosisporites embryonalis -_.__ 32

Cicatricosisporites paradorogensis _-_______ 32

Genus Lycopodium

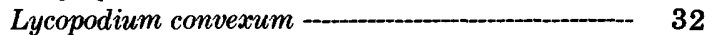

Lycopodium hamulatum -_________- 32

Lycopodium heskemensis -

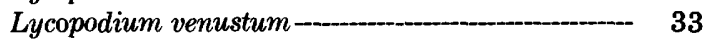

Genus Selaginella - 33

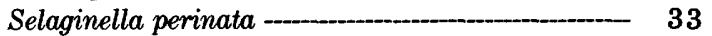

Selaginella sp. A - 33

Selaginella sp. B -_._._._._._. 33

Genus Sphagnum - 34

Sphagnum antiquasporites -_..____ 34

Sphagnum australum 34

Sphagnum stereoides -.____________ 34

Sphagnum triangularum -___________._._._._._. 34

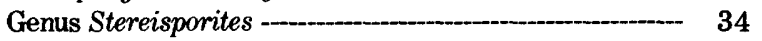

Stereisporites megastereoides - 34

Stereisporites woelfersheimensis_-________ 34

Genus Podocarpus -._- 34

Podocarpus? cappulatus __________ 34

Podocarpus maximus -___________ 35

Genus Pityosporites -_-_-_-_._- 35

Pityosporites longifoliaformis-_______ 35

Genus Pinus --.-_- 35

Pinus cembraeformis -_-____-_ 35

Pinus labdaca - 35

Pinus tenuextima - 36

Genus Picea - 36

Picea grandivescipites-___ 36

Genus Cedrus

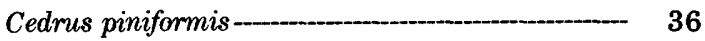

Genus Tsuga-_______- 36

Tsuga ignicula -____________ 36

Genus Sequoiapollenites -._-_._-_._- 36

Sequoiapollenites lapillipites _________ 36

Genus Cupressacites --_._- 36

Cupressacites hiatipites _-__________ 36

Genus Ephedra-_- 36 Ephedra claricristata_____________ 36

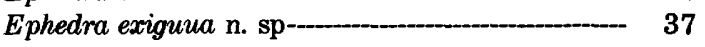

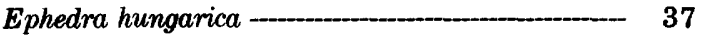

Ephedra? laevigataeformis____________ 37 
Palynology—Continued

Systematic descriptions-Continued

Genus GraminiditesGraminidites gramineoides

Genus Milfordia

Milfordia incerta

Milfordia minima

Genus Aglaoreidia

Aglaoreidia pristina - _._-_._-_._. 38

Genus Momipites

Momipites comyloides

Momipites microfoveolatus -...-_____-_ $\quad 39$

Genus Platycarya -

Platycarya sp-_-_- 39

Genus Triporopollenites -

Triporopollenites? maternus-___________________ $\quad 39$

Genus Ludurigia - 39

Luduigia oculus-noctis -..- 39

Genus Proteacidites -______- 40

Proteacidites? laxus -

Genus Casuarinidites -.._-____-_ 40

Casuarinidites discrepans

Casuarinidites cf. C. granilabratus --_-_-_-_- 40

Genus Triatriopollenites -_._- 40

Triatriopollenites? aff. T. aroboratus -..-_..-..- 40

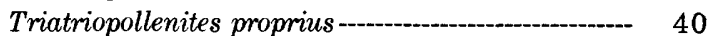

Genus Trivestibulopollenites --._- 41

Trivestibulopollenites engelhardtii -._-_._-_._- 41

Genus Betula -

Betula? sp -.._- 41

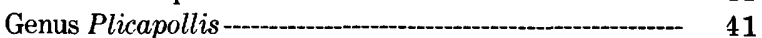

Plicapollis spatiosa -

Genus Thomsonipollis--_-_.- 41

Thomsonipollis magnifica --_- 41

Genus Carya -

Carya simplex-1.-- 42

Carya veripites --_-_-_- 42

Genus Alnus - - 42

Alnus vera --_- 42

Genus Planera - -

Planera? thompsoniana -

Genus Myriophyllum - 42

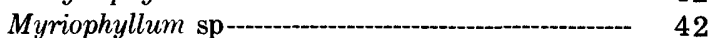

Genus Pterocarya - - 43

Pterocarya stellata -

Genus Juglans -.-- 43 Juglans nigripites -

Genus Juglanspollenites -._-_._-_.-_ 43

Juglanspollenites infrabaculatus--.-_-_-_-_-_-_ 43

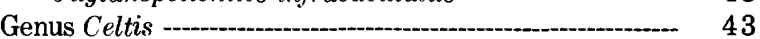

Celtis tschudyi -..- 43

Genus Parsonsidites -._-_._- 43

Parsonsidites conspicuus -.._- 43

Genus Malvacipollis -_- 44 Malvacipollis tschudyi -

Genus Anacolosidites --_-_-_-_- 44

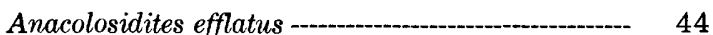
Anacolosidites sp --..- 44

Genus Chenopodipollis --._-_-_-_-_.-- 44 Chenopodipollis $\mathrm{sp}$ - 44

Genus Lymingtonia -

Lymingtonia cf. L.rhetor --_-_-_-_-_-_-_ 44

Genus Monosulcites -.-- 44

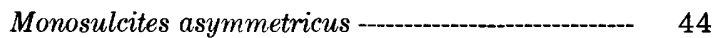

Palynology-Continued Page

Systematic descriptions-Continued

Genus Confertisulcites - - 45

Confertisulcites fusiformis --_-_-_- 45

Genus Monocolpopollenites -._-_._- 45 Monocolpopollenites tranquillus -_._-__ 45

Genus Sabal-_-_. 45

Sabal cf. S. granopollenites-_-_- 45

Genús Arecipites - - 45 Arecipites columellus-_-_ 45

Genus Calamuspollenites -_-___- 45 Calamuspollenites eocenicus -_.___._- 46

Genus Liliacidites - - 46 Liliacidites tritus Liliacidites vittatus -

Genus Nypa---_- 46

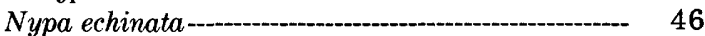

Genus Dicolpopollis Dicolpopollis sp---_-_-_-_- 46

Genus Cupuliferoidaepollenites -_-_-_-_- 46 Cupuliferoidaepollenites liblarensis -_._-____-_ 46 Cupuliferoidaepollenites cf. C. selectus -_-___- 47

Genus Cassia - - 47 Cassia certa-_-__-_ 47

Genus Foveotricolpites -......- 47 Foveotricolpites prolatus -___-_._- 47

Genus Quercoidites --_- 47 Quercoidites inamoenus --_a 47

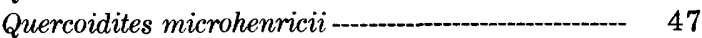

Genus Fraxinoipollenites --_on Fraxinoipollenites medius --_on 48 Fraxinoipollenites cf. $F$. scoticus Fraxinoipollenites variabilis ---_-_-_-_--- 48 Fraxinoipollenites $\mathrm{spp}-$

Genus Platanus - - 48

Platanus occidentaloides $\mathrm{n}$. sp-_-_-_ 48

Genus Salixipollenites Salixipollenites parvus n. sp--_-_- 49

Genus Fraxinus-_-__- 49 Fraxinus? pielii $\mathrm{n}$. sp

Genus Rousea -_-__-_ 49 Rousea araneosa Rousea monilifera $\mathrm{n}$. $\mathrm{sp}$

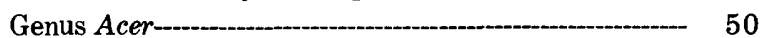
Acer? striatellum - 50

Genus Striatopollis Striatopollis terasmaei -_-___-_ 50

Genus Polycolpites --___ 50 Polycolpites sp- 50

Genus Cupuliferoipollenites -..._-_._- 50 Cupuliferoipollenites spp

Genus Chrysophyllum-_- 51 Chrysophyllum brevisulcatum -._._-_._- 51

Genus Cyrillaceaepollenites -_-_._- 51 Cyrillaceaepollenites kedvesii n. sp-____ 51 Cyrillaceaepollenites megaexactus -______- 51 Cyrillaceaepollenites? ventosus-_-___-___-_ 51

Genus Siltaria -_-_._-_-_ 52

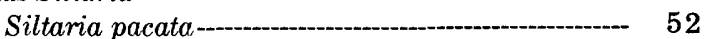
Siltaria cf. S. scabriextima - 52

Genus Araliaceoipollenites -______- 52 Araliaceoipollenites granulatus --_._-__-__-_ $\quad 52$ Araliaceoipollenites megaporifer $\mathrm{n}$. sp----_---- 52 Araliaceoipollenites profundus n. sp - - 53 
Palynology—Continued

Systematic descriptions-Continued

Genus Foveotricolporites--

Foveotricolporites $\mathrm{sp}$

Genus Ilex

Ilex infissa $\mathrm{n} . \mathrm{sp}-$

Ilex media-1- 53

Genus Verrutricolporites-_--- 54

Verrutricolporites cruciatus n. sp--_-_- 54

Verrutricolporites ovalis --.-- 54

Verrutricolporites tenuicrassus n. sp --_-_-_- 54

Genus Nuxpollenites - 54

Nuxpollenites $\mathrm{sp}$-.._- 54

Genus Nyssa -

Nyssa kruschii--.-.-_- 54

Genus Nyssapollenites -

Nyssapollenites pulvinus -

Genus Rhoipites --.-. 55

Rhoipites angustus $\mathrm{n} . \mathrm{sp}-\mathrm{C}_{-}$

Rhoipites latus n. sp-- $\mathbf{5 5}$

Rhoipites subprolatus $\mathrm{n}$. sp-_-_-_ 56

Genus Horniella

Horniella genuina -._-__-_ 56

Horniella modica -

Horniella sp. A--.-- 56

Horniella $\mathrm{spp}$-._-_-_-_.-. 57

Genus Caprifoliipites …_..._. 57

Caprifoliipites incertigrandis n. sp--_-_- 57

Caprifoliipites tantulus n. sp -

Genus Lonicerapollis _._____-_... 57

Lonicerapollis sp- 57

Genus Ailanthipites --

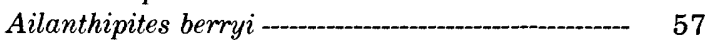

Genus Retitrescolpites -

Retitrescolpites $\mathrm{sp}$--_--- 58

Genus Alangiopollis

Alangiopollis sp- 58

Genus Myrtaceidites --.-- 58

Myrtaceidites parvus
Palynology-Continued

Systematic descriptions-Continued

Genus Cupanieidites --.--.-- 58

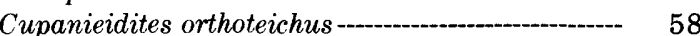

Genus Boehlensipollis -._-_-_- 59

Boehlensipollis hohlii-_-_- 59

Genus Gothanipollis-_- 59

Gothanipollis cockfieldensis --_-_ 59

Genus Bombacacidites-1-_- 59

Bombacacidites nacimientoensis -_._____._. 59

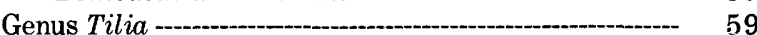

Tilia instructa --_-_-_- 59

Genus Intratriporopollenites --._-_._-_-_-_ 59

Intratriporopollenites stavensis $\mathrm{n}$. sp------- $\quad 59$

Genus Reticulataepollis ---.--.----- 60

Reticulataepollis reticlavata n.sp-_-_-_-_ 60

Reticulataepollis ef. $R$. intergranulata--_-_-- 60

Genus Symplocos -

Symplocos arcuata n. sp--aro

Symplocos ceciliensis

Symplocos contracta $n . \mathrm{sp}-1$

Symplocos gemmata n. sp--_-_-_-_-_- 61

Symplocos jacksoniana - 62

Symplocos tecta $\mathrm{n} . \mathrm{sp}-\mathrm{-}_{-}$

Symplocos? thalmannii -________-_ 62

Symplocos sp-_-_- 62

Genus Nudopollis --_-_- 62

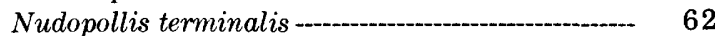

Genus Tetracolporopollenites --a-_-- 63

Tetracolporopollenites brevis $\mathrm{n} . \mathrm{sp}-\mathrm{B}_{-}$

Tetracolporopollenites lesquereuxianus --_-_--- 63

Tetracolporopollenites megadolium -

Tetracolporopollenites $\mathrm{sp}-\mathrm{-}_{-}$

Genus Foveostephanocolporites - - 64

Foveostephanocolporites bellus $\mathrm{n}$. sp-_.__- 64

Genus Ericipites--.-- 64

Ericipites aff. $E$. ericius -

Ericipites redbluffensis $\mathrm{n}$. $\mathrm{sp}$

References cited----_--- 65

Index - -

\section{ILLUSTRATIONS}

[Plates follow index]

Plates 1-3. Pteridophyte spores.

4. Bryophyte and pteridophyte spores and gymnosperm pollen grains.

5-6. Gymnosperm pollen grains.

7. Gymnosperm and angiosperm pollen grains.

8-16. Angiosperm pollen grains.

FIGURE 1. Correlation diagram showing stratigraphic and geographic positions of sampled sections

2. Map showing the sampling localities in Mississippi and western Alabama

3. Chart showing the relative positions of standard microfossil zones at Little Stave Creek, Clarke County, Ala -

4. Chart showing maximum observed ranges of selected sporomorph species in the Jackson Group and adjacent strata of Mississippi and western Alabama--

5-8. Charts showing relative-frequency distribution of:

5. Cupuliferoipollenites spp

6. Momipites coryloides

7. Quercoidites microhenricii

8. Quercoidites inamoenus 


\section{TABLES}

TABLE 1. Published studies on sporomorphs from the upper part of the Claiborne, the Jackson, and the lower part of the Vicksburg Groups of the gulf coast

CONVERSION FACTORS

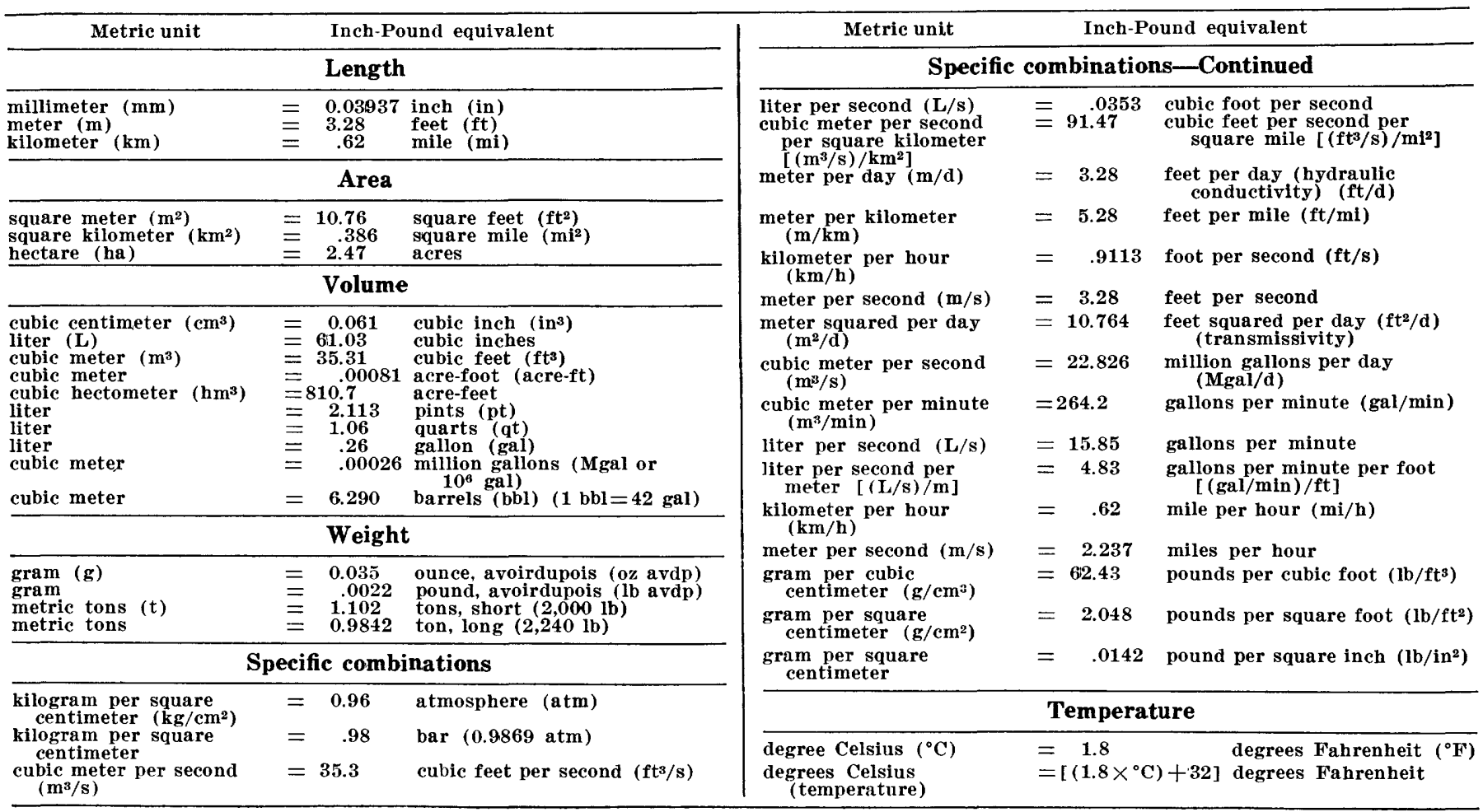




\title{
SPOROMORPHS FROM THE JACKSON GROUP (UPPER EOGENE) AND ADJACENT STRATA OF MISSISSIPPI AND WESTERN ALABAMA
}

\author{
By Norman O. Frederiksen
}

\begin{abstract}
This palynological study is based on 71 outcrop and core samples of the Jackson Group and adjacent strata from the type area of the group in western Mississippi and also from eastern Mississippi and western Alabama. The Jackson Group consists entirely of marine strata in the region of study. It includes the fossiliferous greensands of the Moodys Branch Formation at the base and the calcareous Yazoo Clay at the top.
\end{abstract}

One hundred seventy-four sporomorph (spore and pollen) types are known from the Jackson Group and adjacent strata in the area of study; all but four of them were observed by the writer. The 174 types are assigned to 74 form genera, 37 modern genera, and 25 new species.

Eleven species of pollen grains appear to have accurately determined restricted stratigraphic ranges within the sequence studied. Parsonsidites conspicuus Frederiksen and Ericipites aff. $E$. ericius (Potonié) Potonie have first occurrences (range bottoms) at the base of the Jackson Group. Aglaoreidia pristina Fowler has its first occurrence near the top of the Jackson. Eight species have last occurrences at or just below the top of the Jackson Group. These are Casuarinidites ef. $C$. granilabratus (Stanley) Srivastava, Chrysophyllum brevisulcatum (Frederiksen) n. comb., Cupanieidites orthoteichus Cookson and Pike, Symplocos gemmata n. sp., Nudopollis terminalis (Pflug and Thomson) Elsik, Sabal cf. S. granopollenites Rouse, Caprifoliipites tantulus n. sp., and Nypa echinata (Muller) n. comb.

From the upper part of the Claiborne Group up through most of the Jackson, the dominant sporomorph types are Cupuliferoipollenites spp., Momipites coryloides Wodehouse, Cupuliferoidaepollenites liblarensis (Thomson) Potonié, Momipites microfoveolatus (Stanley) Nichols, Quercoidites microhenricii (Potonié) Potonié, and Araliaceoipollenites granulatus (Potonié) n. comb. All these were probably produced by trees of the Juglandaceae and Fagaceae. Relative frequencies of each of these pollen types fluctuate little within the interval from the upper part of the Claiborne to near the top of the Jackson. Near the top of the Jackson Group, there is a rapid rise to dominance or near dominance of the sporomorph assemblages by Quercoidites inamoenus (Takahashi) n. comb. (Fagaceae, Dryophyllum or Quercus). This remains the dominant sporomorph species through the lower part of the Vicksburg Group.

On the basis of these range and relative-frequency data for spores and pollen grains, the Jackson Group is divided into two zones. Zone I includes the upper part of the Claiborne Group and all but the uppermost part of the Jackson Group; zone II includes the uppermost part of the Yazoo Clay and extends into the overlying Vicksburg Group. The two zones and the boundary between them can be traced from western Mississippi to western Alabama. Sporomorph data support evidence from physical stratigraphy and from other fossils that only a minor disconformity is present between the Claiborne and Jackson Groups in this region. In western Mississippi, the zone I-zone II boundary is below the minor disconformity separating the open marine Yazoo Clay from the uppermost lagoonal part of that formation. Sporomorph data agree with faunal evidence that no unconformity is between the Jack- son and Vicksburg Groups in eastern Mississippi. No sporomorph-bearing samples were available from the uppermost part of the Yazoo Clay at Little Stave Creek in western Alabama; however, samples from above and below the uppermost part of the Yazoo show that the zone I-zone II boundary either coincides with, or is slightly below, the unconformity separating the Jackson and Vicksburg Groups there.

The information on sporomorph ranges and relative frequencies suggests that the flora and the vegetation of southeastern North America changed little from late middle Eocene time until almost the end of the late Eocene. Then, perhaps because of a change in climate, some species disappeared from the regional flora, and one or several species of the Dryophyllum-Quercus complex (represented by the pollen species Quercoidites inamoenus) became dominant members of the coastalplain forest.

\section{INTRODUCTION}

The Jackson Group includes most or all of the upper Eocene strata on the gulf coast. This study is concerned with the Jackson in its type area of western Mississippi and from there eastward into western Alabama. Facies changes along the coast make detailed correlations difficult within the group, and it was hoped that investigation of the sporomorphs might provide new biostratigraphic information. The strata immediately underlying and overlying the Jackson were also studied to determine whether the Jackson differs palynologically from the adjacent strata.

The specific purposes of the investigation were to identify and illustrate the sporomorph species present in the Jackson Group and adjacent strata, to describe and name the new species, to determine the geologic ranges of the species and their relative frequencies at different levels within the sequence studied, and to use the range and relative-frequency data to zone the Jackson Group and to differentiate it from the underlying and overlying units, if possible.

\section{PREVIOUS STUDIES}

Tschudy (1973, p. B2-B3) discussed many of the previous studies on the Eocene palynology of the gulf coast. Papers, excluding abstracts, that have the most relevance to the present work are listed in table 1 . Photomicrographs of the Eocene sporomorphs appear in many papers, but little taxonomic work has been published on late Eocene and Oligocene sporomorphs from the gulf 
TABLE 1.-Published studies on sporomorphs from the upper part of the Claiborne, the Jackson, and the lower part of the Vicksburg Groups of the gulf coast

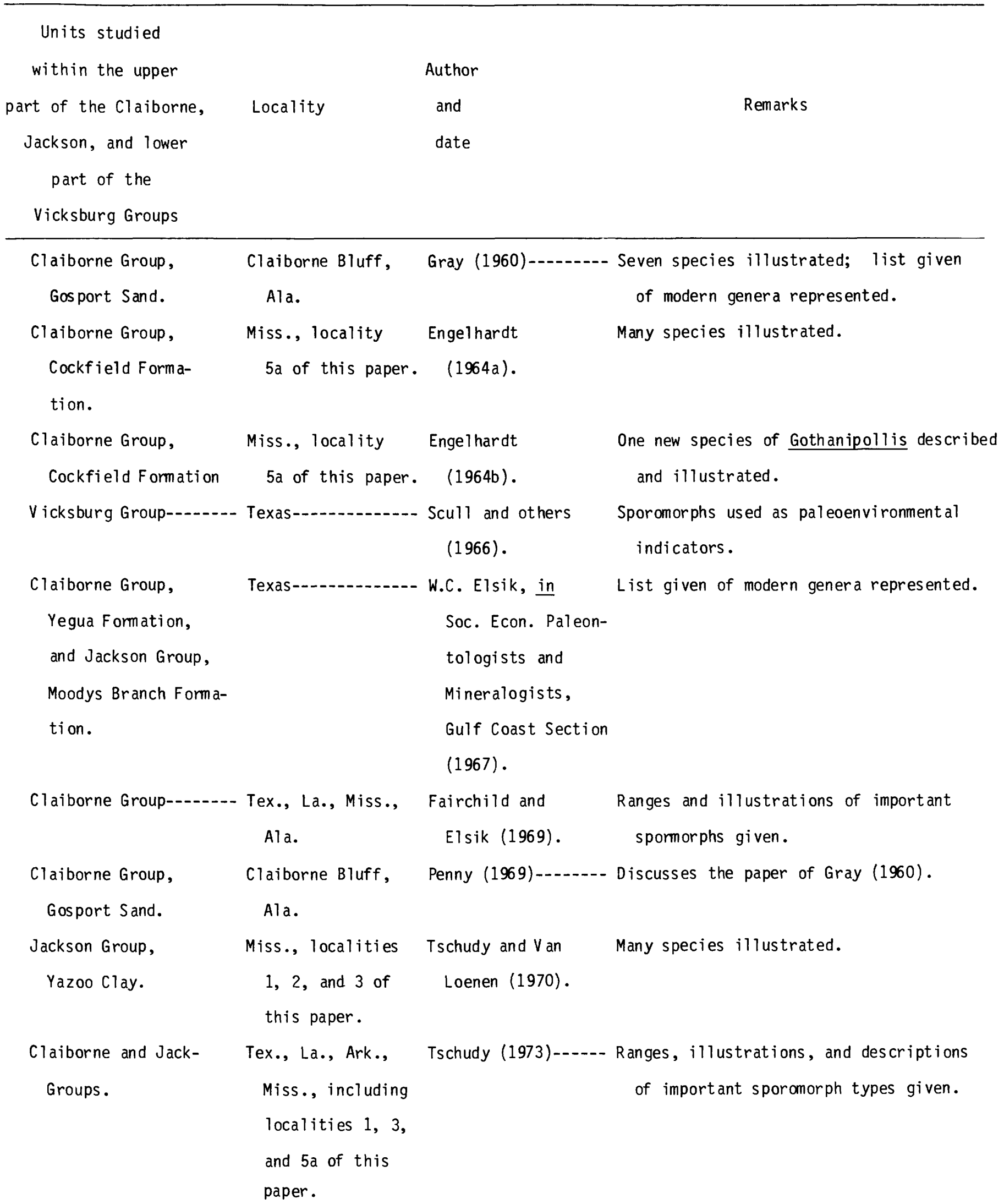


TABLE 1.-Published studies on sporomorphs from the upper part of the Claiborne, the Jackson, and the lower part of the Vicksburg Groups of the gulf coast-Continued

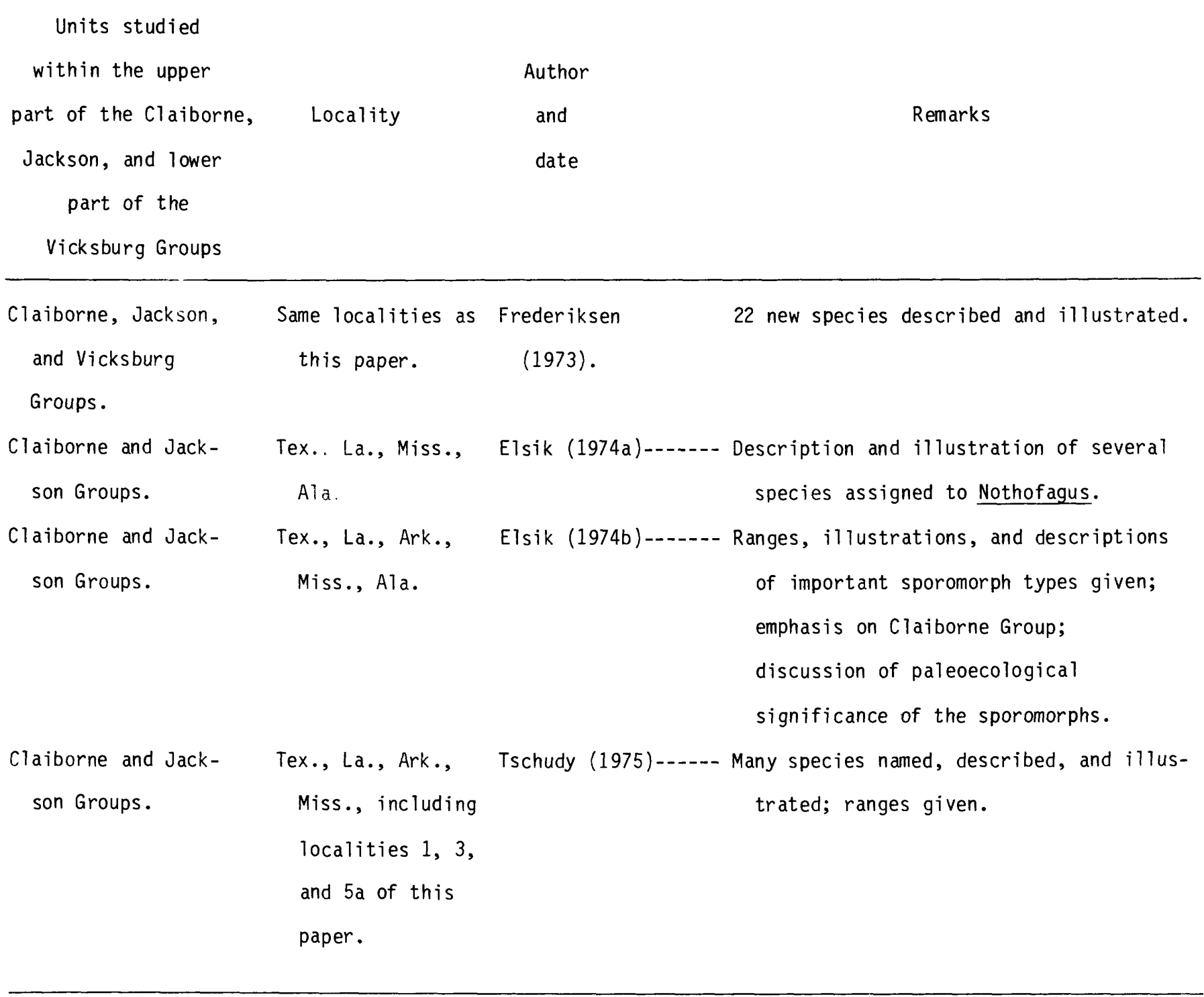

coast; except for Tschudy's (1973, fig. 2) range chart, no previous attempt has been made to zone the sequence from the upper part of the Claiborne Group to the lower part of the Vicksburg.

\section{ACKNOWLEDGMENTS}

Much of this work was completed at the University of Wisconsin and submitted as a doctoral dissertation under the supervision of Dr. L. J. Maher, Jr. I am grateful to Dr. Maher for his encouragement and counsel. The fieldwork, much of the sample preparation, and the computer analyses were supported by the Mobil Research and De- velopment Corporation while I was employed at Mobil's Field Research Laboratory, Dallas, Tex. Gratitude is expressed to the Mississippi Geological Survey for making core material available to me. I thank R. H. Tschudy, U.S. Geological Survey, and Alfred Traverse, J. W. Bebout, and H. T. Ames, all of Pennsylvania State University, for critically reading the manuscript.

\section{STRATIGRAPHY}

From Mississippi to Florida, the Jackson Group represents deposition during a single transgression of the sea that probably lasted throughout late Eocene time 


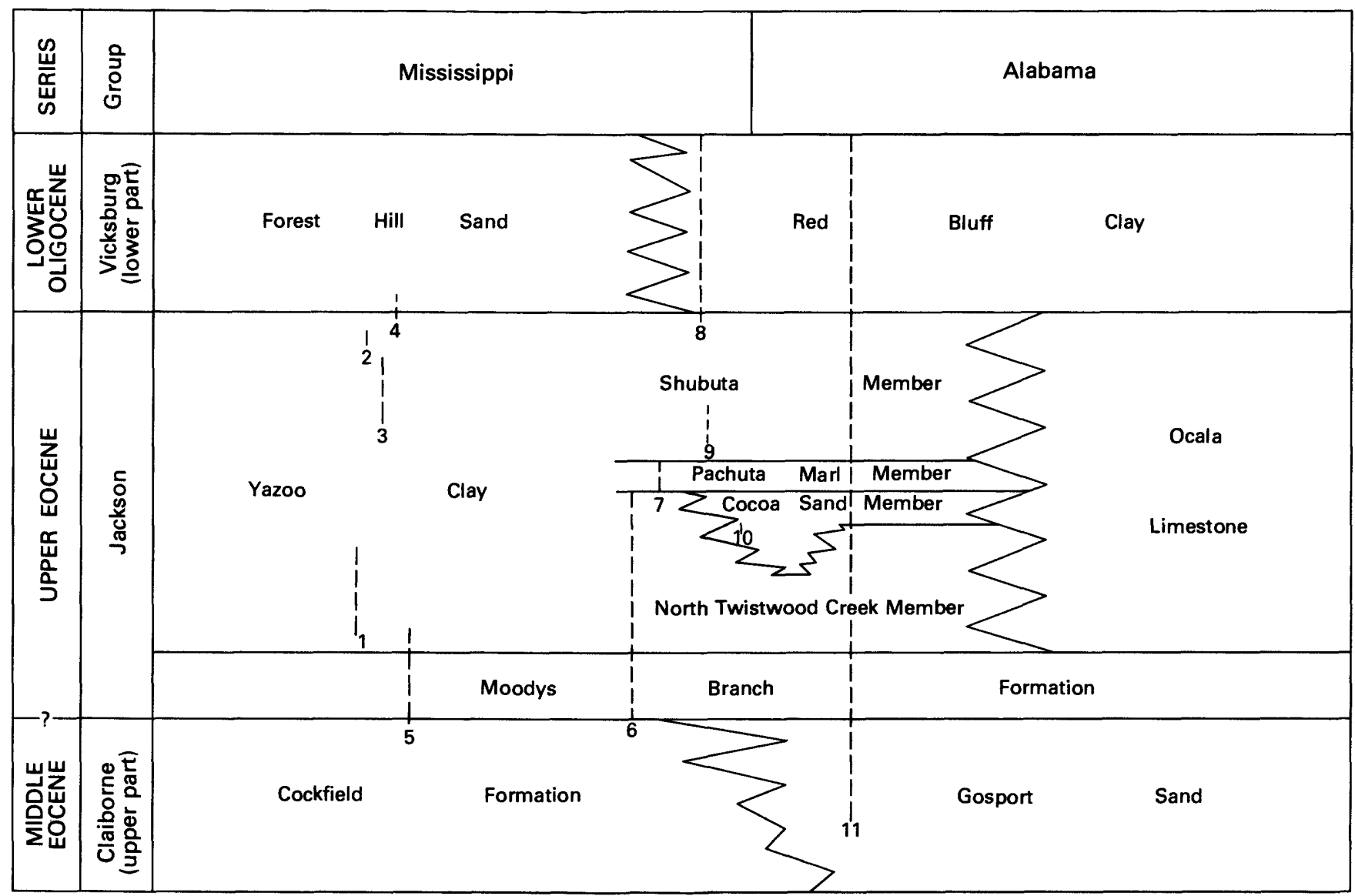

FIGURE 1.-Correlation diagram showing stratigraphic and geographic positions of sampled sections (see also fig. 2). Locality numbers correspond to those in the Locality Register. Thicknesses of units not to scale.

(Toulmin, 1955; Fisher, 1964). The Jackson sediments covered those of the upper part of the Claiborne Group, which consist mainly of nonmarine deltaic and coastalplain deposits (Cockfield Formation) from Texas to eastern Mississippi and of correlative, nearshore marine to nonmarine sediments (Gosport Sand) in eastern Mississippi and Alabama (fig. 1). The sea became generally deeper during Jackson time along the present outcrop belt of Mississippi and western Alabama (Huff, 1970). As the sea retreated at the beginning of Vicksburg time, the Forest Hill deltaic and coastal-plain sediments were deposited in Mississippi and western Alabama, and Red Bluff marine clays and marls were deposited in eastern Mississippi and Alabama.

The Claiborne Group is approximately equivalent to the middle Eocene of Europe, the Jackson Group to the upper Eocene, and the Vicksburg Group to the lower Oligocene (the ages are discussed in the section, Correlation with Standard Microfossil Zones).
The Jackson strata become generally less clastic and more calcareous from Texas, where they are largely sand, to Florida, where they are all carbonates (Murray, 1961). This change is due to increasing distance eastward from the rivers supplying the clastic sediments. This pattern in deposition, however, cannot be observed in all places. In the Mississippi-Alabama area, the late Tertiary central Alabama uplift caused erosion of the normal outcrops and exposed downdip (more calcareous) facies of the Jackson and other strata in the new outcrop belts (Toulmin, 1955). The Little Stave Creek section in southwestern Alabama (loc. 11, figs. 1-2) is on the upthrown side of the Jackson fault, and the section exposed there is about $24-32 \mathrm{~km}$ southwest of the normal outcrop belt of the Jackson Group. Similarly, exposures of the lower part of the group on the Jackson dome in Jackson, Miss. (loc. 5) are $32-40 \mathrm{~km}$ downdip from the normal outcrops of these strata and from where they were sampled at Yazoo City (loc. 1). 


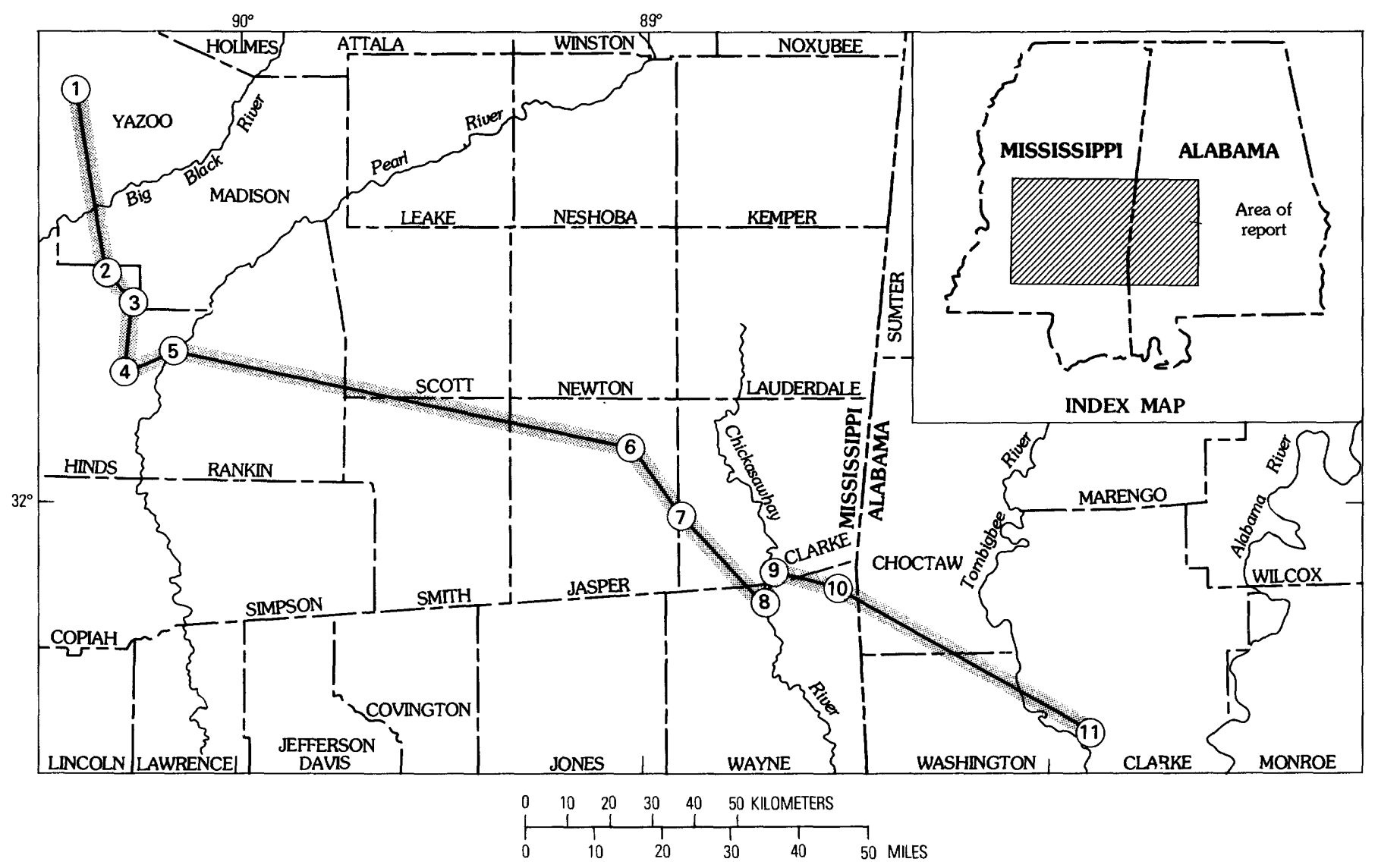

FIGURE 2.-Map showing the sampling localities in Mississippi and western Alabama. Locality numbers correspond to those in the Locality Register.

\section{CLAIBORNE GROUP}

In Mississippi and Alabama, the upper part of the Claiborne Group consists of the Cockfield Formation on the west and the Gosport Sand on the east; these two formations are at least partly time equivalents.

Cockfield Formation.-Typical Cockfield Formation consists of gray to brown, carbonaceous, limonitic, poorly sorted clay, shale, silt and sand, and thin lignite beds. The sediments of all lithologies contain plant material; Chawner (1936, p. 78) noted the abundance of palm leaves in the Cockfield at its type locality in Louisiana. Local variations in both thickness and lithology are the rule, and the sequence appears to represent a typical deltaic and coastal-plain deposit according to Rainwater (1960, fig. 7).

Thin marine interbeds and lenses appear in the upper part of the Cockfield at several localities in eastern Texas and western Louisiana and also in eastern Mississippi. This interval is interpreted as consisting of delta-top and brackish-water to marine bay, lagoon and coastal marsh deposits (Hendy, 1948, p. 26; Treadwell, 1954). A Cockfield facies has been traced into Alabama in the form of nonmarine interbeds into the Gosport Sand. The Cockfield is about $240 \mathrm{~m}$ thick in western and central Texas, 69-168 m thick in western Mississippi, and about 15$31 \mathrm{~m}$ thick in eastern Mississippi (Tourtelot, 1944; Horstman and Gardner, 1960, p. 10; Murray, 1961, fig. 6.41; Moore, 1965, fig. 6).

Gosport Sand.-The Gosport is recognized as a formation only in Alabama and Georgia. The upper greensand part of the Claiborne interfingers with nonmarine lignitic clay and sand in eastern Mississippi and in western to central Alabama; by convention, the whole upper part of the Claiborne complex is termed Cockfield Formation in Mississippi and Gosport Sand in Alabama. The Gosport is $7.6-12.2 \mathrm{~m}$ thick in westernmost Alabama and thins to $1.5-6.1 \mathrm{~m}$ just to the east in Clarke and Monroe Counties (Blanpied and Hazzard, 1938, p. 312314; Chawner, 1952; Toulmin, 1955, fig. 4, and 1962, p. 20 ; Ivey, 1957, p. 54 ). 
The Gosport Sand of western and central Alabama consists of several lithofacies bodies (Blanpied and Hazzard, 1938; Tourtelot, 1944; MacNeil, 1946, p. 34-36; Toulmin and others, 1951, p. 103-104, 109-119). They are listed below in descending order:

Thickness

3. Finely interbedded marine and nonmarine strata---_-

2. Fossiliferous greensand-

1. Nonmarine, Cockfield-type clay and sand

(meters)

$0-6.1$

$0.9-12.2$

$0-13.4$

Lithofacies 3 pinches out eastward in Monroe County, Ala. (Ivey, 1957, p. 54), and both lithofacies 1 and 3 pinch out downdip. At Little Stave Creek, only the greensand (lithofacies 2) is present; the latter is considered to be a beach and nearshore marine deposit (Gardner, 1957, p. 583-584).

\section{JACKSON GROUP}

In Mississippi and western Alabama, the Jackson Group includes, in ascending order, the Moodys Branch Formation and the Yazoo Clay; the Yazoo Clay is divided into four members in eastern Mississippi and western Alabama (fig. 1). The type section of the Jackson Group is in Jackson, Miss. (loc. 5); exposures in eastern Mississippi and western Alabama form a reference section.

Moodys Branch Formation. - The Moodys Branch Formation consists of a mixture of quartz sand, glauconite, and fossils in a marl matrix. The lower part of the formation is a greenish-gray, fine- to coarse-grained, marly, very glauconitic sand; the upper part is lighter colored, more marly, finer grained, and less glauconitic. The Moodys Branch is as much as $13.7 \mathrm{~m}$ thick in western Mississippi, but it thins to $1.8 \mathrm{~m}$ over the Jackson dome (Moore, 1965, fig. 6). It is $3.0-6.1 \mathrm{~m}$ thick in most of eastern Mississippi and western Alabama (Toulmin and others, 1951, p. 121; Huff, 1970, p. 21). The formation has a gradational contact with the Yazoo Clay in Mississippi; the boundary is placed where the sand, glauconite, and macrofossil contents of the Moodys Branch become small. The contact is sharper but still conformable in western and central Alabama.

Yazoo Clay.-The Yazoo Clay in western Mississippi consists of greenish-gray, slightly to very calcareous, slightly sandy and micaceous clay. The clay is largely nonbedded, but some thin lamination is present. Several ledge-forming marl or limestone bands are present. The Yazoo varies from sparsely to very fossiliferous (mostly thin-shelled pelecypods and gastropods). The equivalents of the Yazoo Clay are $300 \mathrm{~m}$ thick in the Rio Grande embayment, are 120-150 m thick in Louisiana and western Mississippi, and thin to $46 \mathrm{~m}$ at the Mississippi-Ala- bama line; the formation generally maintains this thickness of $46 \mathrm{~m}$ until it merges into the Ocala Limestone in central Alabama (Murray, 1961, fig. 6.44).

The formation is divided into four members in eastern Mississippi and western Alabama. In ascending order, these are the North Twistwood Creek, Cocoa Sand, Pachuta Marl, and Shubuta Members.

North Twistwood Creek Member.-Fresh strata of this member have been cored in eastern Mississippi (locs. 6 and 7). These cores show that the member varies from a marl to a calcareous clay and is yellowish- to greenishgray, slightly silty to sandy, sparingly glauconitic, and slightly to very micaceous. The member contains foraminifers, fragments of thin-shelled pelecypods, and fish scales. Bedding is lacking or irregular. The member remains very much the same in western Alabama, although marl and limestone bands appear in the unit at the Alabama River. The North Twistwood Creek is 6-18 m thick in eastern Mississippi and 15-18 m thick in western Alabama; it thins to $12.5 \mathrm{~m}$ at Little Stave Creek and to about $9 \mathrm{~m}$ at the Alabama River (Toulmin and others, 1951, p. 121; Chawner, 1952; Toulmin, 1962, p. 18; Huff, 1970 , p. 40-46).

Cocoa Sand Member.-The Cocoa Sand Member is a massive, bluish-gray sand that ranges from very fine grained to medium grained. It is clayey, micaceous, calcareous, and fossiliferous. Glauconite is present at some localities (for example, at Shubuta Hill and Little Stave Creek). At Little Stave Creek, the member is a very sandy, glauconitic marl. The fossils appear to be of two assemblages, (1) mostly echinoids, and some bryozoans and corals, and (2) pelecypods, gastropods, and fish teeth. The Cocoa is a lenticular body. It is $18.3 \mathrm{~m}$ thick in the type area of westernmost Alabama, is $7.6 \mathrm{~m}$ thick in south-central Clarke County, Miss., and either lenses out westward or becomes very clayey and merges with the North Twistwood Creek Member in western Clarke County, Miss. (Hendy, 1948, p. 26; Toulmin and others, 1951, p. 121; Toulmin, 1955, fig. 4). The member also thins rapidly southward and eastward from the type area; it is $1.8 \mathrm{~m}$ thick at Little Stave Creek.

Pachuta Marl Member. - This member is quite uniform in lithology throughout eastern Mississippi and western Alabama. It is a massive, light yellowish-, bluish-, or greenish-gray marl that is quite sandy, slightly to very glauconitic, and very fossiliferous; fossils contained are Chlamys spillmani (Gabb), bryozoans, and fucoids. A sandy, glauconitic, fossiliferous limestone band marks the base of the member. The Pachuta ranges from 1.5 to $7.6 \mathrm{~m}$ in thickness in eastern Mississippi and western Alabama (locs. 6, 7, 9, 11, this report; Cheetham, 1963 , p. 7; Huff, 1970 , p. 56-57). The member has been traced as a calcareous band as far west as Yazoo County, 
Miss., where it apparently is about $25.9 \mathrm{~m}$ above the base of the Yazoo Clay (Thomas, 1948, p. 18; Murray, 1961, fig. 6.44).

Shubuta Member.-In eastern Mississippi and westernmost Alabama, the Shubuta is a greenish-gray clay that is silty to sandy, glauconitic, slightly micaceous, and calcareous; most of the quartz sand and glauconite grains are near the base. The member becomes more calcareous and glauconitic eastward in Alabama. At Little Stave Creek, it is mostly a greenish-gray marl that is sandy, fossiliferous, and very glauconitic. The member is a limestone in Monroe County, Ala., and to the east (MacNeil, 1946, p. 43). The Shubuta contains an exceptionally diverse fauna of ostracodes and foraminifers, rather abundant bryozoans and pectens, and a species of small coral (Flabellum sp.). This fauna suggests deeper water than during Cocoa-Pachuta time (Gardner, 1957, p. 585; Deboo, 1965, p. 12; Huff, 1970, p. 65).

The Shubuta Member is $25.6 \mathrm{~m}$ thick at the type locality in eastern Mississippi (loc. 9) and thins rapidly to 8$11 \mathrm{~m}$ near the Mississippi-Alabama State line and to 2.1 $m$ in Monroe County, Ala. (Mississippi Geol. Soc., 1948, opposite p. 32; Hendy, 1948, p. 27; Toulmin and others, 1951, p. 122; Deboo, 1965, p. 20). Toward the west it thickens rapidly; the Shubuta equivalent is 107-122 m thick in western Mississippi and makes up the great bulk of the Yazoo Clay in that part of the State (Murray, 1961, fig. 6.44).

\section{VICKSBURG GROUP}

The lower part of the Vicksburg Group in Mississippi and Alabama consists of the Forest Hill Sand on the west and the Red Bluff Clay on the east; these formations are at least partly correlative with each other.

Forest Hill Sand. - The Forest Hill Sand is very similar to the Cockfield Formation in its lithology and depositional environment. It is also very much like the Cockfield because it intertongues with marine strata in eastern Mississippi and western Alabama.

The Forest Hill consists of gray to brown sandy clay, silt, and silty, very fine grained to fine-grained sand. Virtually all the sediments are micaceous and carbonaceous; lignite is present as beds as much as $0.9 \mathrm{~m}$ thick (MacNeil, 1944, p. 1318) and also as interlaminae with clay, silt, and sand. Calcareous streaks are present but are probably rare in various parts of the formation in western Mississippi (Monroe, 1954, p. 71-74; MacNeil, 1944 and 1946). Rather rare marine to brackish-water phytoplankton occur in at least the lower part of the Forest Hill (Frederiksen, 1969). The formation appears to be a deltaic and coastal-plain complex.

The Forest Hill is generally $23-46 \mathrm{~m}$ thick across the whole width of Mississippi. The formation, especially in its lower part, interfingers with the Red Bluff Clay in eastern Mississippi; the Forest Hill then thins rapidly near the Mississippi-Alabama State line as it wedges out over the Red Bluff, reflecting the progradation of the Forest Hill deltaic and coastal plain during early Vicksburg time (MacNeil, 1944, p. 1318-1321; Monsour, 1948, p. 8; Luper, in Luper and others, 1972, p. 29-31; May, 1974 , p. 63-64). The formation is $15 \mathrm{~m}$ thick in westernmost Alabama (Tourtelot, 1944), and is $3 \mathrm{~m}$ thick in northeastern Washington County (Deboo, 1965, p. 21); it is absent $13 \mathrm{~km}$ to the east-southeast at Little Stave Creek.

Red Bluff Clay.--In eastern Mississippi and westernmost Alabama, the Red Bluff is a greenish-gray clay that is silty, glauconitic, calcareous, and very fossiliferous; fossils contained are mainly mollusks and bryozoans, but foraminifers, ostracodes, and plant fragments are also abundant. In the area of the Tombigbee River, the Red Bluff is a yellowish-gray glauconitic marl. The formation is 3-9 $\mathrm{m}$ thick in easternmost Mississippi (May, 1974, $\mathrm{p}$. 58 ), reaches a maximum thickness of about $11 \mathrm{~m}$ in westernmost Alabama (MacNeil, 1944, p. 1321), and thins, as it becomes more calcareous, to $4.0 \mathrm{~m}$ at Little Stave Creek.

\section{JACKSON GROUP CONTACTS}

The lower and upper contacts of the Jackson Group are important to this palynological study in several ways. First, some question exists whether the Jackson is bounded at its top and base by unconformities; palynological evidence may contribute toward answering this question. Secondly, the study may help to clarify whether palynomorphs were reworked from the Claiborne Group into the Jackson, or from the Jackson Group into the Vicksburg Group, that is, whether the recorded ranges of some of the palynomorph species may be too long.

\section{CLAIBORNE-JACKSON CONTACT}

From eastern Texas to southeastern Alabama, the contact between the Claiborne and Jackson Groups is at the base of the Moodys Branch Formation. This contact is thought by many stratigraphers to represent a regional disconformity marking the base of deposits formed during a regional marine transgression.

Many features characterize the boundary between the Moodys Branch and the underlying formations at outcrops along the northern gulf coast.

1. In Mississippi, the contact of the Cockfield with the Moodys Branch is normally between two different lithotypes, the underlying nonmarine to marginal marine dark-gray clay of the Cockfield and the overlying greensand of the Moodys Branch. In Alabama, both 
the Gosport Sand and the Moodys Branch Formation are composed mainly of greensand, and different workers have placed the formation boundary, and thus the group boundary, at different levels within the greensand sequence. However, at some localities, clay interbeds are present in the Gosport, whereas they are absent from the Moodys Branch.

2. The contact is wavy to very irregular. The unevenness of the contact suggests erosion; however, irregular bedding planes are also present within the Gosport and the Moodys Branch, and only minor scouring may be responsible for the undulation.

3. Burrows extend from the Moodys Branch down into the Cockfield and Gosport at almost every outcrop where the contact is exposed. At locality $5 \mathrm{~b}$, the borehole at Riverside Park, Jackson, Miss., the upper 3.0 $\mathrm{m}$ of Cockfield Formation is completely contaminated with burrow fillings of Moodys Branch material. For that reason, the Cockfield at Riverside Park was sampled from the outcrop (loc. 5a). Burrows are also common within both the Gosport and the Moodys Branch; thus, they are not only a contact phenomenon (Thomas, 1942, p. 81; Stenzel, 1952a, p. 31).

4. Phosphatic nodules are characteristic of the basal part of the Moodys Branch.

5. Fossils have not been very useful in defining the Claiborne-Jackson boundary along the northern gulf coast. Where the uppermost part of the Cockfield Formation contains marine interbeds, the megafaunas and microfaunas of these strata are distinctly Jackson in aspect, and probably the only reason for any faunal change across the contact is the change of facies from brackish-water sediments below to normal marine strata above (Blanpied and Hazzard, 1938, p. 313; Stenzel, 1940 , p. $871-894$, and 1952 b, p. 38 ; Hendy, 1948, p. 26; Blake, 1950, p. 174; Treadwell, 1954, p. 2314$2315,2319)$. Similar evidence comes from plant megafossils; Berry $(1924$, p. 29) stated that the flora of the Cockfield Formation was very similar to that of the Jackson Group.

Swift (1968, p. 444) pointed out that "Unconformities of transgressive sequences commonly occur within the basal beds of the sequences, not below them. Such unconformities, called ravinements, separate basal marsh, lagoon, estuarine, and beach deposits from overlying marine sands." The lower contact of the Jackson Group is an excellent example of a ravinement. Slightly deeper erosion probably accompanied the Moodys Branch transgression where marginal marine beds are lacking from the uppermost part of the Cockfield (for instance, at locs. 5, 6, and 7) than where they are present. Fragments of Cockfield clay are abundant in the lower part of the Moodys Branch, and the basal sands of the Moodys Branch probably were derived largely from eroded and winnowed uppermost sediments of the Cockfield (Rainwater, 1964, p. 220; Huddlestun, 1966, p. 41). However, faunal and megafloral evidence suggests that only a diastem or minor disconformity is present at the ClaiborneJackson contact.

\section{JACKSON-VICKSBURG CONTACT}

The Yazoo Clay-Forest Hill Sand contact varies from sharp to gradational in Mississippi. At many localities, no upper sediments of the Yazoo are present that would represent deposition during withdrawal of the Jackson sea. In these places, a minor disconformity must exist between the middle to outer neritic part of the Yazoo and the nonmarine part of the Forest Hill. Where a transition interval consisting of regressive, shallow-marine, or lagoonal sediments (as at loc. 4) exists at the top of the Yazoo, the Yazoo-Forest Hill contact is probably conformable, but a minor intraformational disconformity is probably present between these regressive Yazoo sediments and the typical Yazoo below.

Evidence exists that a disconformity is between the Yazoo Clay and the Red Bluff Clay in some areas:

1. The contact is very irregular at some localities, especially in eastern Mississippi and western Alabama, for instance at locality 8 . However, similar erosion surfaces also are present within the Red Bluff, and in much of Alabama and Florida, no obvious unconformity separates the two formations (Toulmin, 1969, p. 477).

2. Evidence from a variety of fossils suggests the presence of a faunal discontinuity between the Yazoo Clay and the Red Bluff Clay at locality 11, Little Stave Creek; furthermore, the upper part of the Shubuta Member appears to be missing here, and the lower part of the Red Bluff appears to be present (Cheetham, 1957, p. 93, footnote; MacNeil, 1966, p. 2355; Levin and Joerger, 1967; R. W. Barker, in Blow, 1969, fig. 25; Hazel, 1970). This faunal discontinuity corresponds to the Eocene-Oligocene boundary on the gulf coast. In eastern Mississippi, probably no faunal break exists between the Shubuta and the Red Bluff (R. W. Barker, in Blow, 1969, fig. 25; Hazel, 1970, p. 3247; Howe and Howe, 1971 and 1973, p. 630).

3. Reworked Yazoo Clay microfossils and even megafossils have been reported by many workers as being in at least the lower half of the Red Bluff Clay at several localities in eastern Mississippi and western Alabama. Thus, at least some erosion must have taken place at the end of Yazoo time, and reworked Yazoo palyno- 
morphs should be present in the lower part of the Red Bluff just as reworked late Claiborne palynomorphs should be expected in the lower part of the Moodys Branch Formation.

\section{CORRELATION WITH STANDARD MICROFOSSIL ZONES}

Figure 3 shows the planktonic foraminiferal and calcareous nannoplankton zones that have been reported to be in the upper part of the Claiborne, in the Jackson, and

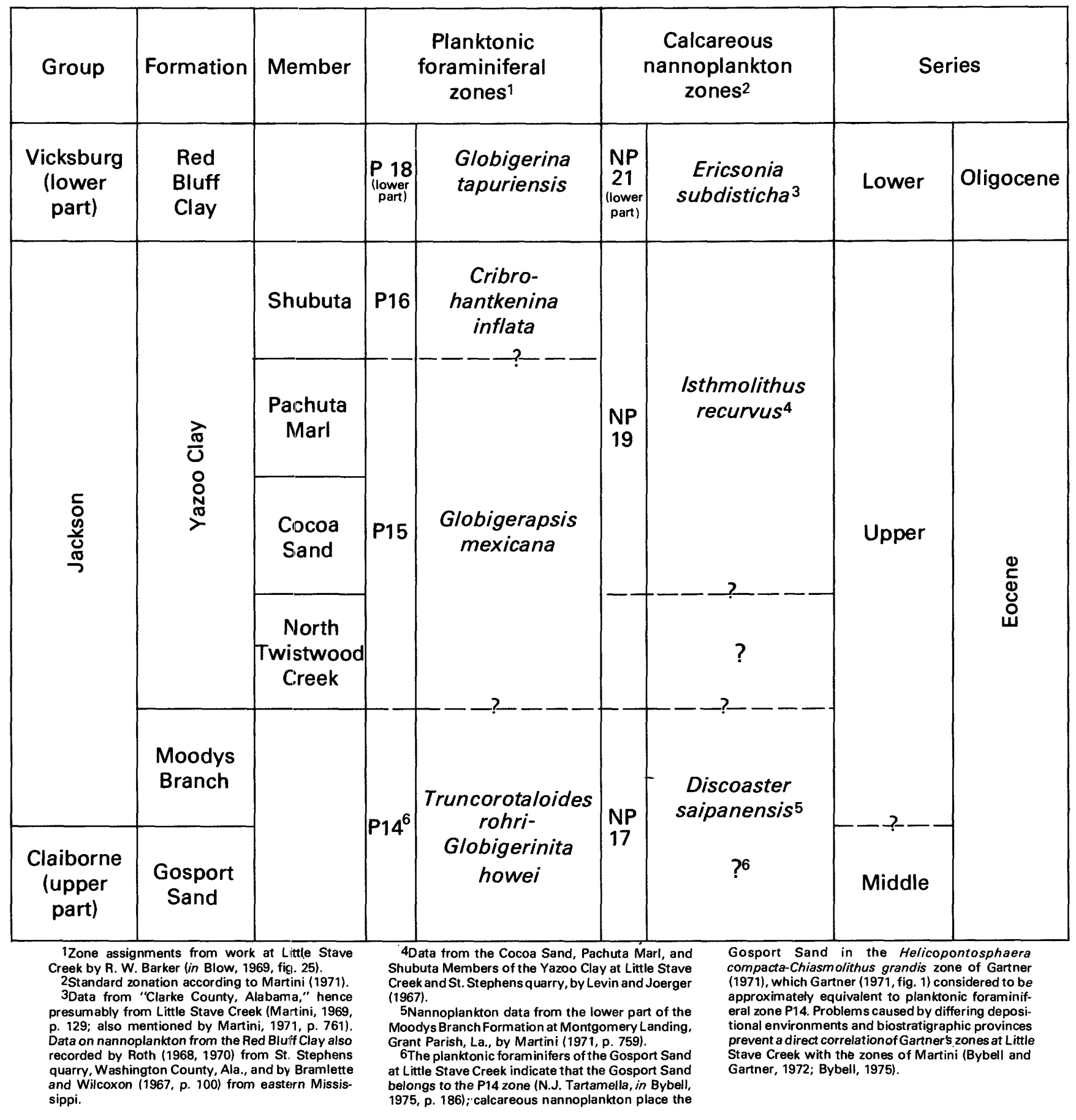

FigurE 3.-Chart showing the relative positions of standard microfossil zones at Little Stave Creek, Clarke County, Ala. Thicknesses of units not to scale. 
in the lower part of the Vicksburg sequence at locality 11, Little Stave Creek, Ala. The correlation of these zones with Tertiary series and stages of Europe is from Martini (1971) and Berggren (1972).

The boundary between the middle and upper Eocene is uncertain even in the type region of northwestern $\mathrm{Eu}$ rope, the age of the Auversian Stage or Substage being the chief bone of contention (Davies and others, 1975, p. 186-187). Berggren (1972, fig. 5) considered zones P 14 and NP 17 to be late middle Eocene in age; Martini (1971, p. 759) noted that the reference (type) sample for NP 17 is from the type section of the Bartonian of England, considered by most workers to be late Eocene in age. It is quite possible that both P 14 and NP 17 straddle the middle-upper Eocene boundary (Blow, 1969, p. 207; Martini, 1971 , table 1). The top of zone P 14 may be within the North Twistwood Creek Member of the Yazoo Clay instead of at its base (R. W. Barker, in Blow, 1969, fig. 25). The top of NP 17 on the gulf coast is unknown, because nannoplankton representing this zone have been reported to be found only in the lower part of the Moodys Branch Formation of Louisiana (Martini, 1971); nannoplankton from the lower part of the Yazoo Clay of Louisiana have been described by Gartner and Smith (1967), but unfortunately their sample contained only long-ranging species. In short, the boundary between the middle and upper Eocene may fall at the base of the Jackson Group, or it may be within the lower part of the Jackson, somewhere below the base of the Cocoa Sand Member of the Yazoo.

An unconformity exists between the Yazoo Clay and Red Bluff Clay at Little Stave Creek, Ala., but this sequence appears to be continuous in eastern Mississippi. Planktonic foraminiferal zone $\mathrm{P} 17$ is present in the upper part of the Shubuta Member of the Yazoo at its type locality (loc. 9; R. W. Barker, in Blow, 1969, fig. 25). Berggren (1972, fig. 3) correlated the P 17-P 18 boundary with the Eocene-Oligocene boundary of Europe, but this correlation may not be exactly correct; Blow (1969, p. 211) stated that the Eocene-Oligocene boundary may be within the upper part of $\mathrm{P} 17$ or within the lower part of $P$ 18. Evidence also exists that the upper part of the Shubuta Member at its type locality may belong to calcareous nannoplankton zone NP 21, which would mean that the Eocene-Oligocene boundary would fall within the Shubuta and not at its top (Stefan Gartner, in Howe and Howe, 1973, p. 630). This determination is based on negative evidence, that is, the lack of the Eocene marker Discoaster barbadiensis Tan Sin Hok in the upper part of the Shubuta (Gartner, 1971, p. 105). In short, it is not yet clear whether the Eocene-Oligocene boundary is within the Shubuta Member or at the top of the member in eastern Mississippi. No studies have been published on the position of the Eocene-Oligocene boundary in western Mississippi.

\section{PALYNOLOGY}

\section{METHODS}

\section{SAMPLING AND PREPARATION}

Sampling. - Samples were collected from six outcrop localities and from cores taken at six localities (figs. 12; Locality Register). Both outcrop and core material were collected from one of the sites, Riverside Park in Jackson, Miss. Outcrop samples were collected after the outcrop had been cut back several centimeters to expose a fresh surface. The individual samples were about fist size or somewhat larger, depending on how hard it was to get a sample. In fairly hard material like the marls at Little Stave Creek, the best method was to cut out a block by driving in a chisel all around the block until it could be pried out. The cores were sampled in wafers about $2-5 \mathrm{~cm}$ thick.

Locality Register.-The individual localities and sections are described in the Locality Register. For most purposes in this study, the sections have been grouped into three long sections, each including the whole Jackson. The western and eastern Mississippi sections are composites; the western Alabama section is a continuous one from locality 11 at Little Stave Creek in Clarke County (see figs. 1, 5-8).

Maceration and slide-making procedures.-The samples were processed with cold concentrated $\mathrm{HCl}$, then with 70 percent $\mathrm{HF}$; they were washed several times with solutions of Darvan $4^{1}$ or Joy household detergent to break down and remove fine organic matter, treated briefly with concentrated $\mathrm{HNO}_{3}$, or with $\mathrm{HNO}_{3}$, plus $\mathrm{KClO}_{3}$, washed several times with weak $\mathrm{NH}_{4} \mathrm{OH}$, and centrifuged twice in $\mathrm{ZnCl}_{2}$ solution (specific gravity, 1.65-2.0). The float fraction was stained with Safranin $O$ and mounted on cover slips with Clearcol or Natrosol. The cover slips were cemented to slides by Paraplex or Elvacite 2044.

\section{TYPE SPECIMENS}

The slide designations show the sample number, the maceration letter (some of the samples were processed several times to get the best results), and the slide number. For example, the slide designation 10558 A-1 indicates sample 10558 , maceration $\mathrm{A}$, and slide 1 . The coordinates listed in the holotype descriptions and the plate

\footnotetext{
${ }^{1}$ Any trade names in this publication are used for descriptive purposes only and do not constitute endorsement by the U.S. Geological Survey.
} 
[M.G.S., Mississippi Geological Survey]

$\begin{array}{lll}\text { Loc. } & \text { Location } & \text { Depth below top } \\ \text { No. } & \text { and sample numbers } & \text { tion to sample } \\ & \text { or to top of } \\ & \text { unit } \\ & \text { Feet Meters }\end{array}$

1 Yazon City.

M.G.S.

horehole,

$\mathrm{SEE}_{\frac{1}{4}} \mathrm{SW}_{\frac{1}{4}} \mathrm{SE}^{\frac{1}{4}}$

sec. 32,

T. $12 \mathrm{~N}$. ,

R. 2 W.,

Yazoo

County, Miss.
Jackson Group

$$
\text { Yazoo Clay-....... } 30
$$$$
10672 \ldots \ldots \ldots
$$$$
\text { 10675-_-_...- } 70.5
$$$$
10676 \text {-........ } 100
$$

10678 -........ 140

$10680-\ldots-\ldots$

Moodys Branch

Formation-.......- 188

Claiborne Group

Cockfield Formation 214

Jackson Group

Yazoo Clay-......-. 8

$10863-\ldots \ldots-\ldots$

$10864 \ldots \ldots-12$

of east-west

gravel road in

$\mathrm{SW}_{\frac{1}{4}} \mathrm{SE}^{\frac{1}{4}} \mathrm{NW} \frac{1}{4} \mathrm{sec}$.

5, T. 7 N., R.

1 W., Hinds

County, Miss.

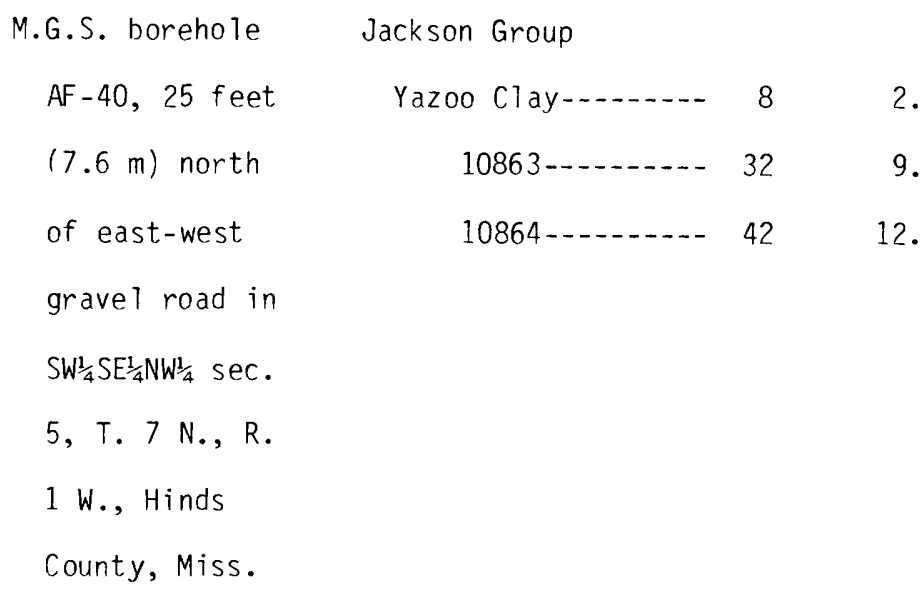

Type locality of the Yazoo Clay,

9.1 which in this area is about

9.8500 feet $(152 \mathrm{~m})$ thick (Mellen,

21.51940, p. 19-20). Electric log

30.5 reproduced by Moore and others

42.7 (1964, fig. 4).

54.9

57.3

65.2
Cores were described by Moore

2.4 (1965, p. 132). The Yazoo

9.8 Clay is here about 485 feet

$12.8(148 \mathrm{~m})$ thick, and the cored

Yazoo begins within 10 feet

$(3.0 \mathrm{~m})$ of the Yazoo Clay-Forest

Hi11 Sand contact (Monroe, 1954,

pт. 2; Bicker, 1965, p. 4). 


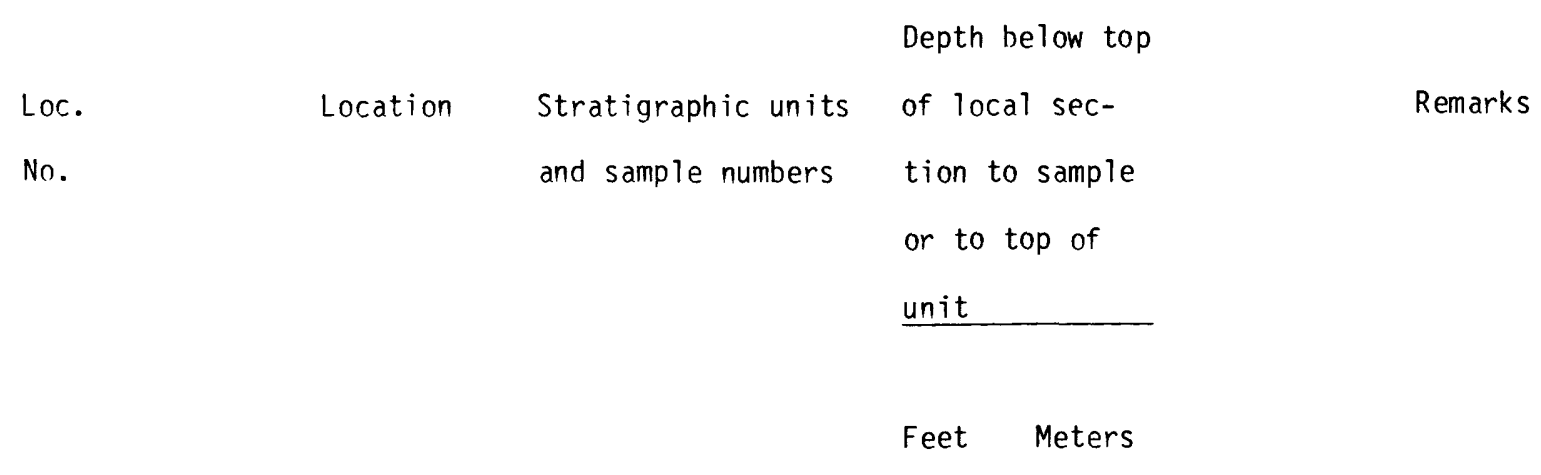

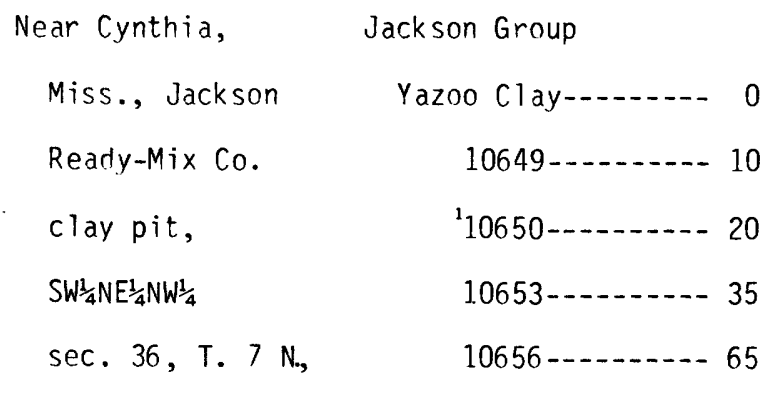

R. 1 W., Hinds

County, Miss.

\begin{abstract}
Forest Hill.
M.G.S. borehole

AF -8 ,

$\mathrm{SE}^{\frac{1}{4}} \mathrm{SE}^{\frac{1}{4}} \mathrm{NE}^{\frac{1}{4}} \mathrm{sec}$.

22, T. 5 N.,

R. 1 W., Hinds

County, Miss.
\end{abstract}

Vicksburg Group

Byram Formation

Glendon Limestone

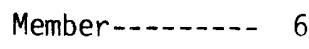

Marianna Limestone

Mint Spring Mar 1

Member-..--.-- ?

Forest Hill Sand--- 18

'10620-_......-. 27
The top of the pit is probably about

0

3.0

50 feet $(15.2 \mathrm{~m})$ below the Yazoo

Clay-Forest $\mathrm{Hill}$ Sand contact;

6.1 the Yazoo Clay is here $380-400$

10.7 feet (116-122 $\mathrm{m})$ thick

19.8 (Monroe, 1954, pl. 2; Bicker, 1965,

pl. 4). Photographs and descrip-

tions of the locality were provided by Priddy (1960, figs. 9, 27, 29), Geor. Soc. America, Southeastern

Sec. (1964, p. 8), Moore (1965,

figs. 11, 14), and Parks (1965,

figs. 6-7).

Type locality of the Forest $\mathrm{Hill}$

Sand. The electric log, a photo-

graph of the cores, and a

1.8 description of the section in the hole appeared in Moore (1965,

figs. 16,17, p. 117).

5.5

8.2 


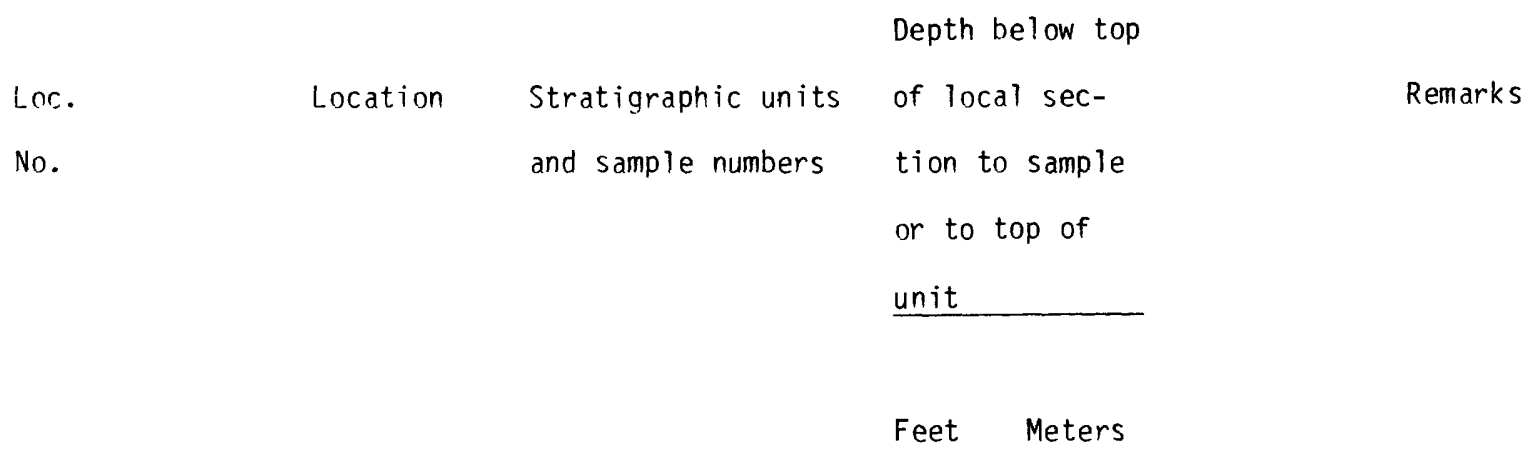

Vicksburg Group--Con.

Forest Hill Sand-Con.

$10625 \ldots \ldots 2$

$10627 \ldots \ldots \ldots$

Jack son Group

\begin{tabular}{|c|c|}
\hline Yazoo Clay-_...- 69 & 21.0 \\
\hline $10629 \ldots \ldots 9$ & 21.0 \\
\hline${ }^{1} 10630 \ldots \ldots$ & 21.6 \\
\hline $10631 \ldots 72$ & 22.0 \\
\hline $10632 \ldots \ldots 7$ & 23. \\
\hline
\end{tabular}

5a Riverside Park expo- Jackson Group

sure $N W_{\frac{1}{4}} N W^{\frac{1}{4}} \mathrm{Sec}$.

Yazoo Clay--.-.-. 0

36 , T. 6 N.,

Moodys Branch

R. 1 E., Hinds

Formation-.....- 10

County, Miss.

$$
\begin{aligned}
& \text { Claiborne Group } \\
& \text { Cockfield Forma- } \\
& \text { tion-........- } 26 \\
& 14958 \ldots \ldots \\
& 14959
\end{aligned}
$$

$5 b$

Riverside Park.

M.G.S. borehole

$A F-17,800$ feet

(244 m) from west

line and 750 feet
Jackson Group

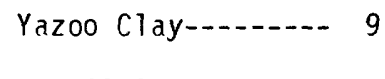

$10635-\ldots 19$

$10637 \ldots \ldots-\ldots 29$

10639

39
15.9

19.2

21.0

21.0

21.6

22.0

23.5

0

3.0

Reference locality for

the Moodys Branch Formation. The section was described by $E$. $H$. Rainwater (in Soc. Econ. Paleontologists, Mineralogists, Gulf Coast Section, 1960) and Huff

7.9 (1970, p. 22-23).

8.8

9.8

The electric log and sample descrip-

2.7 tions were given by Moore (1965,

5.8 fig. 9 and p. 122).

8.8

11.9 


\begin{tabular}{|c|c|c|c|c|}
\hline \multirow[t]{2}{*}{$\begin{array}{l}\text { Loc. } \\
\text { No. }\end{array}$} & \multirow[t]{2}{*}{ Location } & $\begin{array}{l}\text { Stratigraphic units } \\
\text { and sample numbers }\end{array}$ & \multicolumn{2}{|c|}{$\begin{array}{l}\text { Depth below } \\
\text { of local sec } \\
\text { tion to samp } \\
\text { or to top of } \\
\text { unit }\end{array}$} \\
\hline & & . & $\mathrm{Fee}$ & \\
\hline & \multicolumn{4}{|c|}{ Jackson Group--Con. } \\
\hline & $(229 \mathrm{~m})$ from north & Moodys Branch & & \\
\hline & line of $\mathrm{sec} .36$ & Formation--.-..- & & 13.1 \\
\hline & T. 6 N., R. 1 E., & $10641 \ldots \ldots$ & & 14.9 \\
\hline & Jackson, Hinds & '10642 & 4 & 16.5 \\
\hline & \multirow[t]{4}{*}{ County, Miss. } & $10643-\ldots$ & & 17.7 \\
\hline & & Claiborne Group-...-. & 5 & 19.8 \\
\hline & & Cockfield Formation & 8.5 & 17.8 \\
\hline & & ${ }^{1} 10645 \ldots$ & & 19.8 \\
\hline
\end{tabular}

6 Near Rose Hill, Jackson Group

$0.5 \mathrm{mi}(0.8 \mathrm{~km})$ southwest of the type locality of the North

M.G.S. borehole

Yazoo Clay

Pachuta Marl

Member-_..-.. 0 ? 0 ?

North Twistwood

Creek Member-.- 17

10657

10658

10659

10660

10661

Twistwood Creek Member of the

Yazoo Clay. The electric log was reproduced by Huff (1970, fig. 7)

5.2 and the cores were described by

6.1-6.6 W. H. Moore (in Huff, 1970,

9.1-9.6 p. 255).

Moodys Branch

$$
\begin{array}{rl}
\text { Formation-a. } 64 & 19.5 \\
10662 \ldots-\ldots-71.5 & 21.3-21.8 \\
10663 \ldots \ldots-81.5 & 24.4-24.8
\end{array}
$$




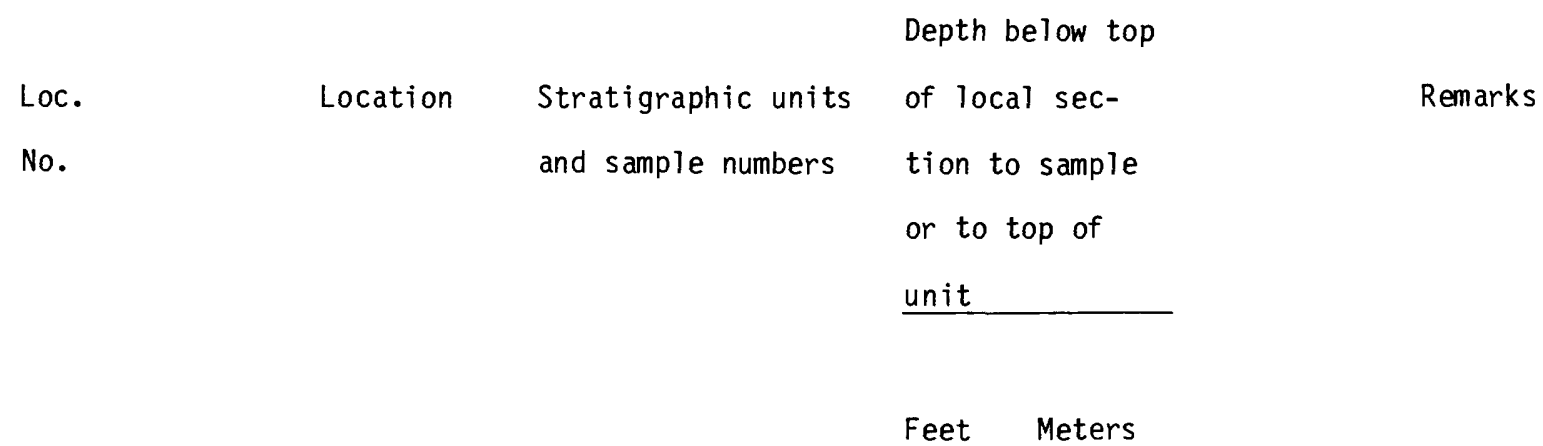

Claiborne Group

Cockfield Formation 88

7 Barnett. M.G.S. Jackson Group

borehole in SW $\frac{1}{4} N^{\frac{1}{4}} \quad$ Yazoo Clay

sec. 30, T. 2 N.,

R. 14 E., Clarke

County, Miss.

Shubuta Member---

3.5

Pachuta Mar 1

Member-...-..-.- 11

$14974-\ldots 18-20$

North Twistwood

Creek Member--- 22

10690

'10692-_-

Moodys Branch Forma-

tion-_........ 81

10696

Claiborne Group

Cockfield Formation 95

8
Near Hiwannee, expo- Vicksburg Group

sure in the cut-

bank on the east

Red Bluff Clay----- 12

$10525 \ldots \ldots-\ldots$

$10529-\ldots$

$10530 \ldots \ldots-28$

as awhay River,

$\mathrm{NW}^{\frac{1}{4}} \mathrm{SW}^{\frac{1}{4}} \mathrm{sec} .28, \quad$ Jackson Group

T. 10 N., R. 7 W., Yazoo Clay

Wavne County,

Shubuta Member--- 30

Miss.
10531 - 31

26.8

$2.5 \mathrm{mi}(4.0 \mathrm{~km})$ south-southwest of the type locality of the Pachuta

1.1 Marl Member of the Yazoo Clay.

3.4 The electric $\log$ and partial section description appeared in Huff

5.5-6.1 (1970, p. 256-257 and fig. 12).

6.7

14.0

17.1

24.7

26.2

29.0

Reference locality for the Red Bluff

3.7 Clay. The section was illustrated

4.3 and described by the Mississippi

7.9 Geological Society (1948, stop 9,

8.5 opposite p. 34), by B. W. Brown

and W. J. Huff (in Soc. Econ.

Paleontologists and Mineralogists,

9.1 Gulf Coast Section, 1963) and by

9.5 Huff $(1970$, p. 61, 63). 


\begin{tabular}{lll} 
& & \\
Loc. & Lecth below top & Stratigraphic units \\
No. & of local sec- \\
& tion to sample \\
& or to top of \\
& unit numbers \\
& Feet Meters \\
\hline
\end{tabular}

9 Shubuta Hill, expo- Vicksburg Group, sure in $\mathrm{N}_{\frac{1}{2}} \mathrm{NW}^{\frac{1}{4}}$ Red Bluff clay--.-- 0

0

sec. 10, T. 10 N., Jackson Group

R. 7 W., Clarke Yazoo Clay County, Miss. Shubuta Member--- 11 $10512--\ldots-0-71$ $10513-\cdots+-76$

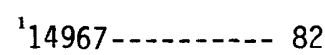

$$
10515
$$

Pachuta Marl

Member-_-_-_-.- 95

$14971---0-100$

Cocoa Sand

Member-_._-_-101

10

$$
\begin{array}{cr}
\text { Shiloh Creek, expo- } & \text { Jackson Group } \\
\text { sure in SW } \frac{1}{4} \mathrm{sec} . & \text { Yazoo Clay } \\
18, \text { T. } 10 \mathrm{~N} ., & \text { Cocoa Sand } \\
\text { R. } 5 \text { W., Wayne } & \text { Member }- \\
\text { County, Miss. } & 14972-
\end{array}
$$

0

9.5
30.8

3.4

21.6

23.2

25.0

27.0

29.0

30.5

0

Type locality of the Shubuta Member of the Yazoo Clay. The section was described and illustrated by the Mississippi Geological Society (1948, stop 8, opposite p. 32) and by Huff (1970, p. 60-61 and figs. $15,16)$.

.0

.


Loc.

No.
Location Stratigraphic units and sample numbers
Depth below top

of local sec-

tion to sample

or to top of

unit

Feet Meters
Remarks

27.4 See also Smith and others (1944)

27.7 and Bandy (1949, figs. 1, 2).

28.4

29.0

30.8

Jackson Group

Yazoo Clay

Shubuta Member---103 31.4

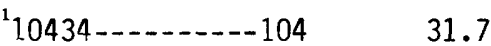

$14962-\ldots-110 \quad 33.5$

$14963 \ldots \ldots-\ldots$

Pachuta Marl

Member-a--_---120 36.6

${ }^{1} 10433-\ldots-\ldots$

$14964 \ldots \ldots \ldots$

Cocoa Sand

Member-_-_-_---125 38.1

$14965-\ldots \ldots+39$

North Twistwood

Creek Member---131 39.9

10542 -._-_-_-136 41.5

$10544 \ldots \ldots \ldots$

${ }^{1} 10545 \ldots \ldots$

$10546-\ldots-157 \quad 47.9$

$10547-\ldots-\ldots-0-169 \quad 51.5$ 


$\begin{array}{ll}\text { Location } & \begin{array}{l}\text { Depth below top } \\ \text { Stratigraphic units of local sec- } \\ \text { and sample numbers tion to sample } \\ \text { or to top of } \\ \text { unit }\end{array} \\ & \text { Feet Meters }\end{array}$

Jackson Group--Con.

Moodys Branch

Formation---.-.-172

$10548-\ldots-175$

$10549-\ldots-185$

$10551-\ldots-193$

$10553-200$

$10555-\ldots-204$

Claiborne Group

Gosport Sand--.---206

$10556-\ldots-207$

$10557-\ldots-210$

${ }^{1} 10558 \ldots \ldots-216$

Lisbon Formation---217

Tallahatta

Formation-.-.---364
52.4

53.3

56.4

58.8

61.0

62.2

62.8

63.1

64.0

65.8

66.1

111.0

\footnotetext{
${ }^{1}$ Sample not fully analyzed.
}

explanations locate the specimens on the Zeiss micro- $\mid$ dinates for the center point of a 25.4- by 76.2-mm (1- by scope that I used at Mobil Research and Development 3 -in.) standard microscope slide are $38.6 \times 118.1 \mathrm{~mm}$ Corporation, Dallas, Tex. On this microscope, the coor- $\quad$ (horizontal $\times$ vertical axes); the horizontal coordinates 
decrease toward the right edge of the slide and the vertical coordinates decrease toward the bottom edge of the slide. The coordinates can be converted, and the specimens can be located easily on any microscope having standard millimeter stage scales. The slides are on file at the National Center of the U.S. Geological Survey, Reston, $\mathrm{Va}$.

\section{METHODS OF ANALYSIS}

One hundred fifty-six samples were collected. All these were processed, and 56 were fully analyzed. Additional data about the occurrence of species were also obtained from 15 more samples; information is based largely on photographed specimens. Analyzed samples were about 3-12 $\mathrm{m}$ apart through most of the sections, but some samples were less than $1 \mathrm{~m}$ apart, especially where the individual units are thin as at Little Stave Creek.

At least one complete slide of each sample was scanned at about $200 \times$ to establish the presence of the rarer species so that more reliable range data could be obtained. The data on species presence are biased because the slides containing very abundant specimens have more species represented than the slides containing relatively few specimens. This bias is not too important for purposes of the present study, however. The ranges are based on so many samples that the number of species in each sample does not matter very much, and most rare species are not important in characterizing the palynomorph assemblages. Moreover, most of the slides contain thousands of grains each.

Counts were made to determine the relative frequency of each species in each sample. Oil-immersion objectives were used, providing a total magnification of $675 \times$ or $1,250 \times$. For most samples, at least three traverses were made across different parts of the cover slip on one slide; for a few samples, traverses were made across more than one slide. All specimens were identified if possible and recorded until at least 100 (for most samples, 150-200) identified spores and pollen grains had been counted; sample 10632, from the upper part of the Yazoo Clay at locality 4, contained only 57 grains. Probably the number of pollen grains and spores that could not be identified was 5 percent or less of the total pollen-spore count. The relative frequencies are expressed in terms of categories such as "infrequent" and "occasional" to emphasize that they are only rough estimates of the true relative frequencies of each species in the samples; the categories are defined in table 2. However, on figures $5-8$, the relative-frequency data are presented in the form of 0.95 confidence intervals for the true relative frequencies, calculated according to the formulas of Mosimann (1965; see also Maher, 1972).
TABLE 2.-Relative-frequency categories
Definition
(to nearest
Designation
whole percent)

$\begin{array}{ll}<1 & \text { "Infrequent" } \\ 1-5 & \text { "Occasional" } \\ 6-20 & \text { "Common" } \\ 21-40 & \text { "Abundant" } \\ >40 & \text { "Very abundant" }\end{array}$

Ranges and relative frequencies of the sporomorph taxa are based on data presented in my dissertation (Frederiksen, 1969, available from University Microfilms). In evaluating the accuracy of ranges, one needs to know the proportion of samples within the observed range in which the taxon was observed; in this paper, the information is provided in the Occurrence sections of the Systematic Descriptions as, for example, 9/41, meaning the taxon was observed in 9 out of 41 counted samples within the taxon's range.

Very little modern pollen contamination was observed in the slides. Only about a dozen modern grains were recognized altogether; these included one grain of Gramineae and one of Chenopodiaceae, and the rest were Compositae.

\section{DISTRIBUTION OF THE SPOROMORPHS}

The observed geologic range of each taxon found in this study is given in the Systematic Descriptions section. It was virtually impossible to distinguish between reworked specimens and indigenous ones except by knowing the ranges given in published studies of the 
taxa. Some species that were observed in the Jackson Group and adjacent strata have been reported to be present within the interval of Cretaceous to lower middle Eocene but not in the middle of the middle Eocene or higher. Some of these species were seen in samples in this study, and it is still not clear whether they were reworked or not. Species that are more likely than others to be represented by reworked specimens include Monoleiotriletes sp., Ephedra? laevigataeformis (Bolkhovitina) n. comb., Casuarinidites discrepans (Frederiksen) n. comb., Casuarinidites ef. C. granilabratus (Stanley) Srivastava, Plicapollis spatiosa Frederiksen, Thomsonipollis magnifica (Pflug) Krutzsch, and Symplocos? thalmannii (Anderson) n. comb.

Figure 4 shows the observed stratigraphic distributions of species that appear to have restricted ranges and that were observed in a reasonable number of counted samples. All these species are also present in some of the uncounted samples. Aglaoreidia pristina Fowler has its first occurrence near the top of the Jackson. Nypa echinata (Muller) n. comb. has not been observed in samples from strata higher than about the middle of the Shubuta Member of the Yazoo. I observed the species in only eight samples (and Tschudy and Van Loenen (1970) also reported finding it in two samples of the Yazoo Clay), but its observed last occurrence (range top) may be close to the true one; in Europe, Nypa died out late in the Eocene or early in the Oligocene (Tralau, 1964, p. 24). Parsonsidites conspicuus Frederiksen, Casuarinidites cf. C. granilabratus (Stanley) Srivastava, and Caprifoliipites tantulus $\mathrm{n}$. $\mathrm{sp}$. were recorded as being from a higher percentage of counted samples than the other species whose ranges are shown in figure 4 , and their observed ranges are probably accurate estimates of the true ranges. $P$. conspicuus has been also found by Tschudy (1973, p. B17) to have its first occurrence at the base of the Jackson Group. Another group of species whose ranges are plotted in figure 4 consists of Ericipites aff. $E$. ericius (Potonié) Potonié, Chrysophyllum brevisulcatum (Frederiksen) n. comb., Cupanieidites orthoteichus Cookson and Pike, Symplocos gemmata n. sp., Nudopollis terminalis (Pflug and Thomson) Elsik, and Sabal cf. S. granopollenites Rouse. These six species were observed in a smaller percentage of counted samples than species of the previously mentioned group. Therefore, the plotted ranges for species of the group of six may not be exactly the true ranges for these species. However, the pattern of all species ranges shown in figure 4 indicates that the main floral break in the sequence from the upper part of the Claiborne Group to the lower part of the Vicksburg is at or near the top of the Jackson Group, and that the floral break at the base of the Jackson apparently is minor. The sporomorph assem- blages within the upper part of the Claiborne group change (Tschudy, 1973), but this change is less marked than the change at or near the top of the Jackson. Tschudy (1973, fig. 2) reported that five pollen types have last occurrences in the upper part of the Claiborne; I have found that four of these range at least to the top, or nearly to the top, of the Jackson. These four pollen types are Nudopollis terminalis (Pflug and Thomson) Elsik; Porocolpopollenites spp. (psilate-microreticulate) of Tschudy, which is synonymous at least in part with Symplocos contracta n. sp.; Quercoidites microhenricii (Potonié) Potonié; and Porocolpopollenites spp. (verrucate) of Tschudy, which is synonymous at least in part with Symplocos gemmata n. sp.

Figure 4 also implies that most late Eocene sporomorph species in Mississippi and Alabama have long ranges. In fact, of the total 112 species that occur in 8 or more of the 71 counted and uncounted samples, 89 or 90 species are known to range at least from the upper part of the Claiborne to the lower part of the Vicksburg, inclusive. Of the 22/112 species apparently having restricted ranges within the sequence studied, only those whose ranges are shown in figure 4 were observed in enough samples that the ranges were considered reasonably likely to be accurate.

Two sporomorph zones have been identified in the sequence from the upper part of the Claiborne to the lower part of the Vicksburg. Zone I includes all the strata from the upper part of the Claiborne to near the top of the Jackson. Zone II includes the uppermost part of the Yazoo Clay, at least the lower part of the Forest Hill Sand, and the entire Red Bluff Clay.

Listed in order of decreasing mean relative frequency per sample, the most abundant sporomorph types in zone I are:

Cupuliferoipollenites spp.

Momipites coryloides Wodehouse

Cupuliferoidaepollenites liblarensis (Thomson) Potonié

Momipites microfoveolatus (Stanley) Nichols

Quercoidites microhenricii (Potonié)

Potonié

Araliaceoipollenites granulatus (Potonié) n. comb.

All these species of pollen grains were probably produced by trees of Fagaceae and Juglandaceae. The changes in the relative frequencies of the sporomorph types within zone I are not regular or consistent; figures 5-7 show the data for three representative taxa, $\mathrm{Cu}$ puliferoipollenites spp., Momipites coryloides, and Quercoidites microhenricii. The calculated relative frequency of a given species does vary within the zone, but 
PALYNOLOGY

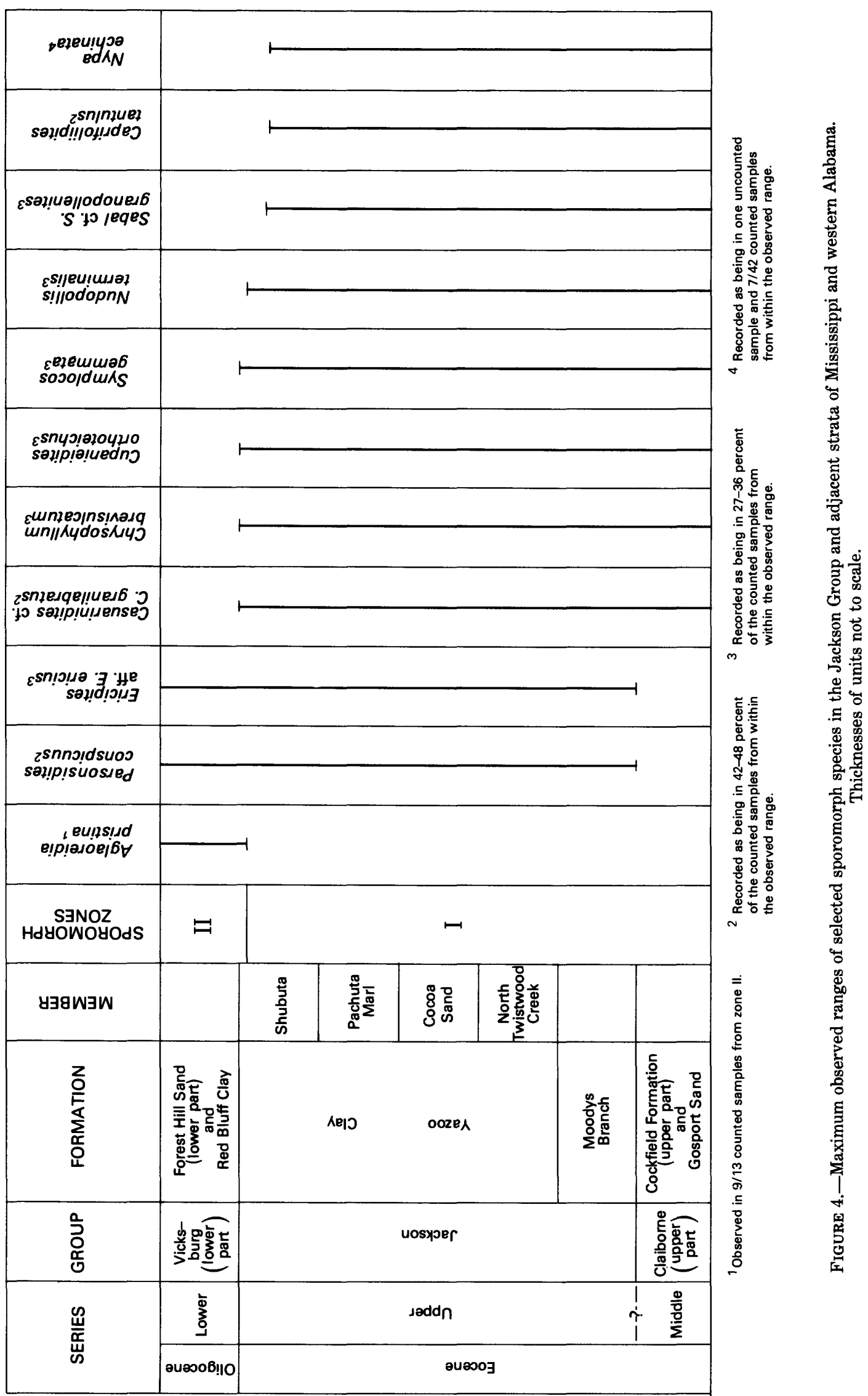


many of these variations are not statistically significant, as shown by the overlap of the confidence interval bars. Where fluctuations are significant, they do not form patterns of maxima or minima that can be correlated from one area to another. The variations from sample to sample within stratigraphic units are greater than the variations from unit to unit. Furthermore, no significant last occurrences and only two significant first occurrences of sporomorph species are within the zone (fig. 4). For these reasons, sporomorphs cannot be used for correlations within zone I, for instance, of the Pachuta Marl Member of the Yazoo from eastern Mississippi westward across the State.

Two pollen species are important in defining zone II. One of these, Aglaoreidia pristina Fowler, is restricted to the zone II part of the sequence (fig. 4). The species is never more than 2 percent of any sample assemblage, but it has been observed in $9 / 13$ of the counted samples from the zone. Additional data on the distribution of Aglaoreida spp. appear in the discussion of this genus in the Systematic Descriptions section. Quercoidites inamoenus (Takahashi) n. comb. is the most abundant constituent of, and best marker for, zone II. It is "infrequent" to "occasional" (rarely "common") in most samples of zone I, whereas it is mostly "abundant" to "very abundant" in zone II (fig. 8).

The first and last occurrences of species and the changes in the sporomorph relative frequencies coincide only in part with unconformities present between the Jackson and Vicksburg Groups or within the upper part of the Jackson (see the section, "Jackson-Vicksburg Contact"). The lowermost stratigraphic level known for zone II is about $13.7 \mathrm{~m}$ below the top of the Yazoo Clay in western Mississippi (loc. 2, sample 10864). In this area, the unconformity is between the open marine shelf deposits of the upper part of the Jackson (loc. 2, samples 10864 and 10863) and the overlying lagoonal deposits (loc. 4, samples 10632 and 10631) immediately below the Forest Hill Sand. Here the zone I-zone II boundary is placed below the unconformity, at the base of sample 10864, which has the lowermost occurrence of Aglaoreidia pristina in this area; however, the relative frequency of Quercoidites inamoenus is only slightly higher in samples 10864 and 10863 than in the samples below (fig. 8). In eastern Mississippi, the upper two-thirds of the Shubuta Member is represented by only one sample, which is from the very top of the member and which belongs to zone II; thus, no sporomorph samples are available from the uppermost part of zone I from eastern Mississippi, and the position of the zone I-zone II boundary here is unknown. Nevertheless, the zone boundary in this area is definitely below the contact between the Jackson and Vicksburg Groups, and sporomorph data agree with faunal evidence that no unconformity exists between the groups there. At Little Stave Creek in western Alabama (loc. 11), evidence from other fossils indicates that the upper part of the Shubuta Member is missing. The unconformity is not obvious from inspection of figure 8 , where the relative frequency of Quercoidites inamoenus is seen to rise gradually from the upper part of zone I into zone II. The zone boundary was placed somewhat arbitrarily at the base of the "bluegray clay" of Smith and others (1944). The only sample available from the upper $2.1 \mathrm{~m}$ of the Shubuta Member at Little Stave Creek (sample 10434) was nearly barren of palynomorphs. Thus, zone II may be present here at the very top of the preserved Yazoo Clay.

It was impossible to determine how many, if any, of the sporomorphs recovered from the lower part of the Jackson Group had been reworked from the upper part of the Claiborne. Few, if any, species make a last appearance in the lower or middle part of the Jackson, suggesting that if any Claiborne sporomorphs were reworked into Jackson sediments, they were of species that range into the Jackson anyway, or else they were of species that continued to be contributed to the sediments throughout Jackson time. Whether significant numbers of Jackson sporomorphs were redeposited in the lower part of the Vicksburg Group is also unknown. As mentioned in the section Jackson-Vicksburg Contact, calcareous microfossils reworked from the Yazoo Clay are common in the lower part of the Red Bluff Clay in eastern Mississippi and western Alabama. Redeposited calcareous microfossils have not been recognized in the Forest Hill Sand to my knowledge.

Below is a list of the 21 species that occur in the Jackson Group and in the Red Bluff Clay, but that have not been observed in the Forest Hill Sand. It is possible that some or all of these species were reworked into the Red Bluff Clay, and that their true range tops are in the upper part of the Yazoo Clay.

Lycopodium heskemensis (Pflanzl) n. comb.

Podocarpus? cappulatus n. name

Sequoiapollenites lapillipites (Wils. and Webst.) Krutzsch

Milfordia minima Krutzsch

Proteacidites? laxus Fred.

Thomsonipollis magnifica (Pflug) Krutzsch

Carya veripites Wils. and Webst.

Malvacipollis tschudyi (Fred.) n. comb.

Cupuliferoidaepollenites cf. C. selectus (Pot.) n. comb.

Cassia certa (Fred.) n. comb.

Foveotricolpites prolatus Fred.

Siltaria pacata (Pflug) n. comb.

Siltama cf. S. scabriextima Trav. 
Araliaceoipollenites granulatus (Pot.) n. comb. Araliaceoipollenites megaporifer $\mathrm{n} . \mathrm{sp}$.

Araliaceoipollenites profundus n. sp.

Verrutricolporites ovalis (Pot.) n. comb.

Horniella genuina (Pot.) n. comb.

Horniella modica (Mamczar) n. comb.

Ailanthipites berryi Wodeh.

Symplocos tecta n. sp.

However, there are several reasons to believe that many of the above-mentioned species may actually range into the Vicksburg Group. First, sporomorph data are available from only two counted samples and one uncounted sample of Forest Hill Sand; thus, many of these species may be found to occur in the Forest Hill when more samples of the formation are examined. Second, the fact that a number of species have been observed to have last appearances at or near the top of the Jackson Group (fig. 4) shows that these species at least were not redeposited in the Vicksburg.

In summary, the sporomorph species range and relative-frequency data support evidence from physical stratigraphy and from other fossils in suggesting that there was little or no break in deposition from the late middle Eocene to the early late Eocene in Mississippi and western Alabama. Several new angiosperm pollen types made first appearances at the beginning of Jackson time, but in general there was little apparent change in either the flora or the vegetation of southeastern North America from the late middle Eocene until almost the end of the Eocene. A change in the flora (species present) began late in Jackson time and apparently was completed before the beginning of Vicksburg time. It was marked almost entirely by the loss of species, either by emigration or extinction; little evidence exists for the introduction of new species, either by immigration or evolution. The change in the vegetation (the plant communities) also began late in Jackson time. The main event was the rapid rise in abundance of a species of Quercus or Dryophyllum (represented by pollen of Quercoidites inamoenus), which apparently became a dominant member of the coastal-plain forest in southeastern North America by early in Vicksburg time.

\section{SYSTEMATIC DESCRIPTIONS}

This section deals with the taxonomy of the sporomorphs and summarizes the occurrence of each type in my material. Synonymies listed under the specific and subspecific names include only the most important references, that is, those where different names were used or where the description was emended. Also listed among the synonymies are references to specimens previously reported from the Jackson Group and adjacent strata of the gulf coast.

Each new name is based on at least ten specimens unless otherwise noted. In the descriptions, the word "design" is used to designate the pattern on the exine that one sees in plan view. For instance, many tegillate exines appear punctate or granulate in plan view even though the surface of the exine may be smooth (grana are smaller than coni, verrucae, etc., but larger than puncta, and they give an LO-effect; puncta are $<0.5 \mu \mathrm{m}$ in diameter and give an LO- and (or) an OL-effect). The appearance of the exine in optical section is also described. The grain sizes are mostly averages of several measurements made on each grain. For triangular grains, the three axes of the triangle were measured and averaged; for round or nearly round grains, the long and short axes were averaged. For oval grains, "size" means the length of the long axis. The size measurement includes the ornamentation unless otherwise stated.

One hundred seventy-four sporomorph types are listed in this section. These include $\mathbf{1 1 6}$ previously named species, 25 new species, and 33 sporomorph types that are not given formal specific names mainly because so few specimens have been found. One of the previously named species, Podocarpus andiniformis Zaklinskaya, 1957, is given a new name, $P$.? cappulatus. Four of the 174 sporomorph types were not observed by me but were recorded by Engelhardt (1964a) as being present in the Cockfield Formation of western Mississippi and (or) by Tschudy and Van Loenen (1970) as being present in the Yazoo Clay of western Mississippi.

Following is a list of the new species named in this paper:

Ephedra exiguua n. sp.

Platanus occidentaloides $\mathrm{n}$. $\mathrm{sp}$.

Salixipollenites parvus $\mathrm{n}$. sp.

Fraxinus? pielii n. sp.

Rousea monilifera $\mathrm{n}$. sp.

Cyrillaceaepollenites kedvesii $\mathrm{n}$. $\mathrm{sp}$.

Araliaceoipollenites megaporifer $\mathrm{n}$. sp.

Araliaceoipollenites profundus n. sp.

Ilex infissa n. sp.

Verrutricolporites cruciatus $\mathrm{n}$. sp.

Verrutricolporites tenuicrassus n. sp.

Rhoipites angustus $\mathrm{n}$. sp.

Rhoipites latus n. sp.

Rhoipites subprolatus $\mathrm{n}$. sp.

Caprifoliipites incertigrandis n. $\mathrm{sp}$.

Caprifoliipites tantulus n. sp.

Intratriporopollenites stavensis $\mathrm{n} . \mathrm{sp}$.

Reticulataepollis reticlavata $\mathrm{n}$. $\mathrm{sp}$.

Symplocos arcuata n. sp. 


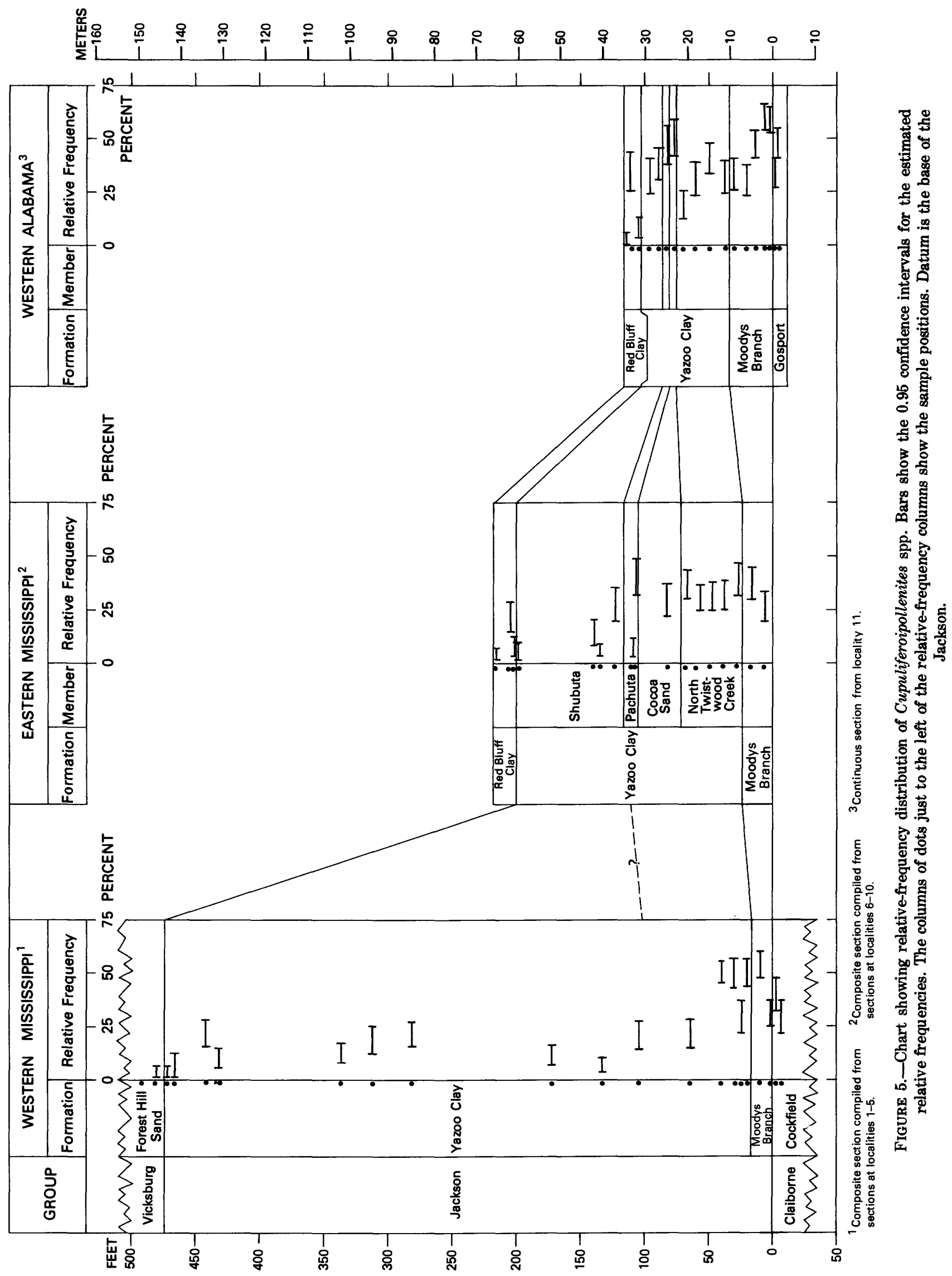


PALYNOLOGY

萜造

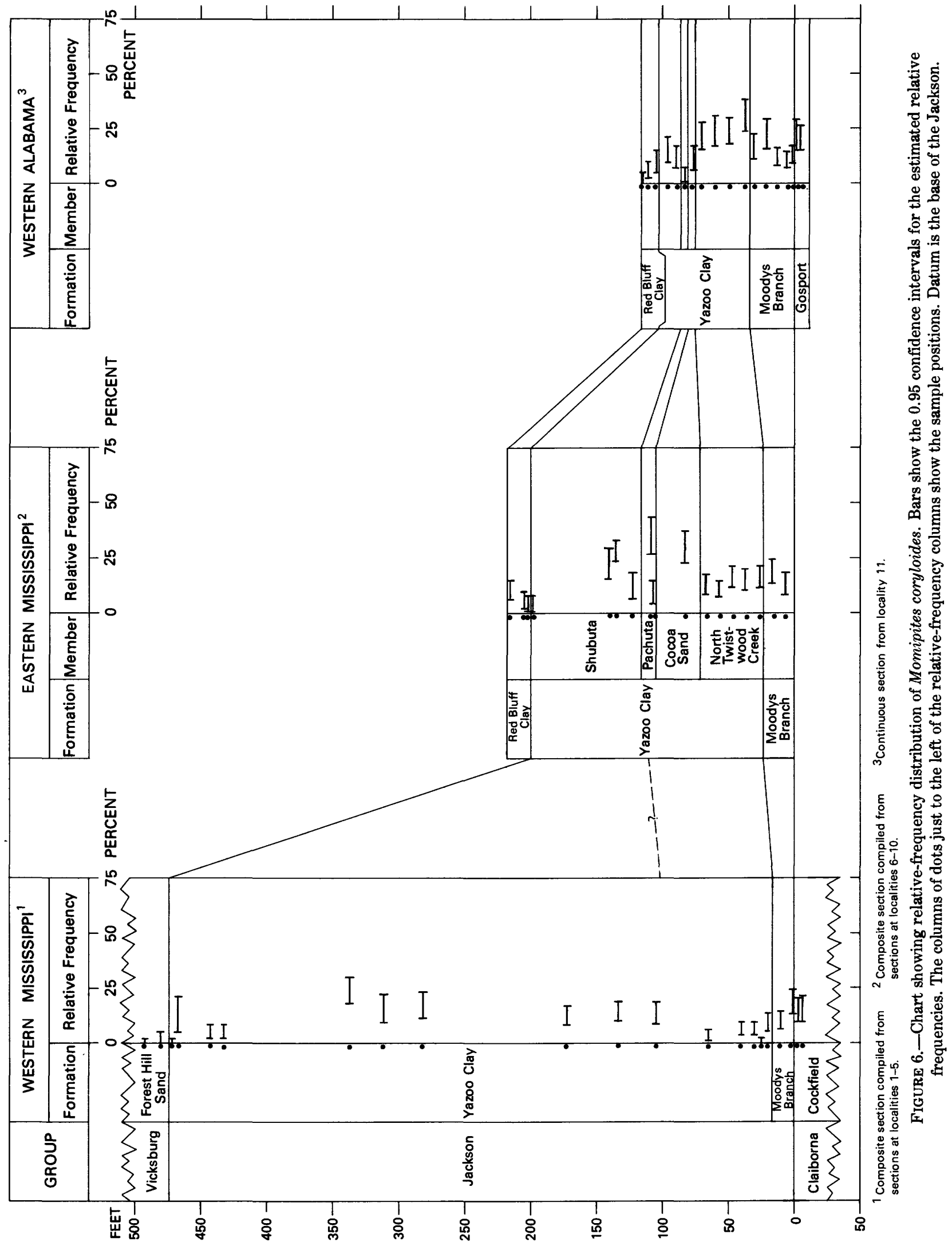


SPOROMORPHS, JACKSON GROUP AND ADJACENT STRATA, MISSISSIPPI AND ALABAMA

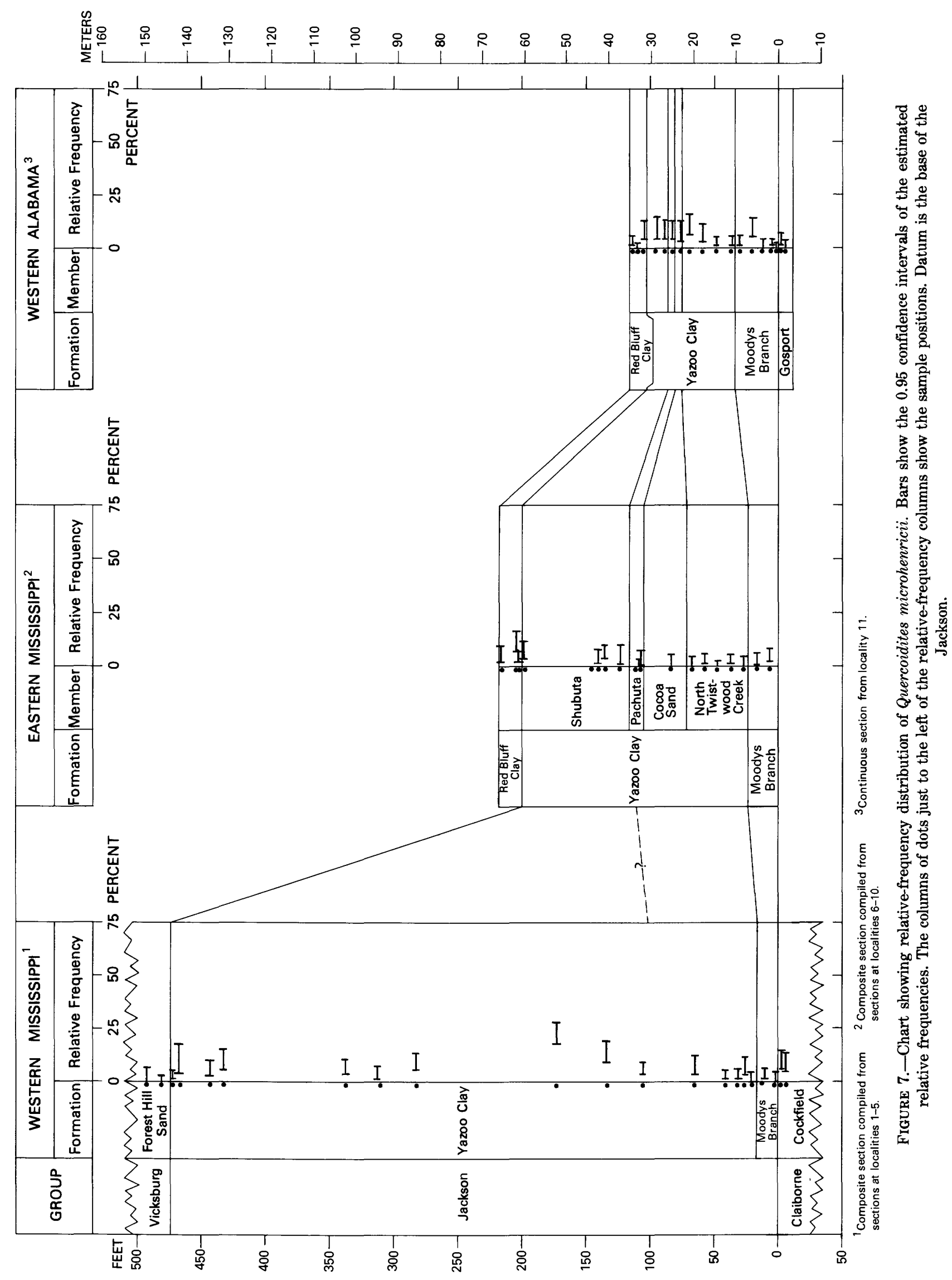


PALYNOLOGY

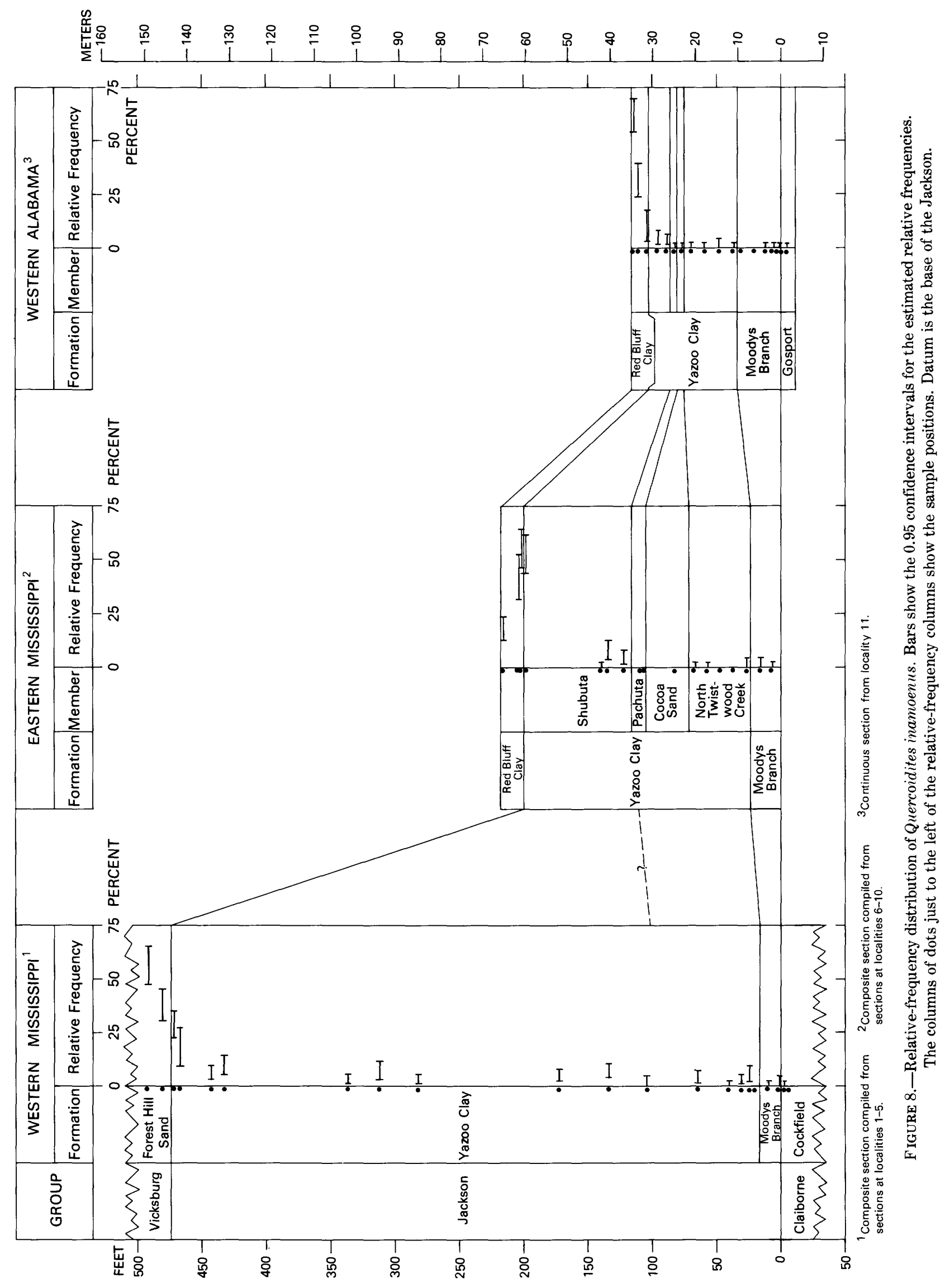


Symplocos contracta $\mathrm{n} . \mathrm{sp}$.

Symplocos gemmata n. sp.

Symplocos tecta n. sp.

Tetracolporopollenites brevis $\mathrm{n}$. sp.

Foveostephanocolporites bellus n. sp.

Ericipites redbluffensis n. sp.

The 174 species and subgeneric groups are assigned to 111 genera, 74 of them being form genera and 37 being modern genera. By assigning a species of Eocene sporomorphs to a modern genus, I indicate that the fossils are very similar to modern sporomorphs of that genus and are quite different from sporomorphs of any other genus as far as I know. For example, the pollen of modern Ephedra is completely distinctive as far as known, and I have assigned the Eocene Ephedra-like pollen grains to that genus. In using modern generic names within reason, I follow the lead of paleobotanists who routinely assign fossil leaves, fruits, and other plant organs to modern genera (for instance, in Graham, 1972). An important reason for using names of modern genera where possible is that it is difficult to use sporomorphs in interpreting paleoecology and paleoclimatology unless the sporomorphs can be linked to modern genera whose ecological and climatological requirements and limits are known. Some paleobotanists (for instance, Hughes, 1963; Dilcher, 1973, p.16) claim that the use of modern generic names makes a fossil flora appear more modern than it actually is, and that evaluating the true history of a genus is difficult if misidentifications of sporomorphs are published. Thus, when botanists and paleobotanists compile lists of occurrences of modern genera in ancient floras, they must annotate each occurrence so that the reader can determine which kind of organ was used to identify the genus, when and by whom the genus was identified, and whether a published illustration or description by which the reader can verify the identification is available. Otherwise, lists of modern genera (or lists of fossil genera and species, for that matter) are impossible to evaluate. Obviously, a generic identification is more likely to be correct if it is based on several kinds of organs than if it is based on only one.

One taxonomic problem that could not be dealt with here is the question of when if ever the genus Pollenites became valid. In common with nearly all previous authors, I assume that this genus was valid in all the 1931 papers of Potonié, even though this may not be strictly true if it is decided that the genus was never properly described. According to the International Code of Botanical Nomenclature (Stafleu and others, 1972, Art. 43), a species is not validly published if the genus to which it is assigned was not valid at the same time or previously.
Genus LAEVIGATOSPORITES Ibrahim, 1933

Laevigatosporites haardtii (Potonié and Venitz) Thomson and Pflụg

Plate 1, figure 1

Sporites haardti Potonié and Venitz, 1934, p. 13, pl. 1, fig. 13. Laevigatosporites haardti (Potonié and Venitz) Thomson and Pflug, 1953 , p. 59, pl. 3, figs. 27-38.

Laevigatosporites sp. Tschudy and Van Loenen, 1970, pl. 1, fig. 1.

Affinity.-This species could well represent spores from any or all of the following fern families: Aspidiaceae, Aspleniaceae, Blechnaceae, Gleicheniaceae, Lomariopsidaceae, Polypodiaceae, Pteridaceae.

Occurrence.-Very widespread stratigraphically (at least Cretaceous to Holocene) and ecologically; in my material, the species is present in nearly all samples and is "infrequent" to "common."

\section{Genus POLYPODISPORONITES Potonié, 1931c}

Polypodii(?)-sporonites Potonié, 1931c, p. 556.

Polypodiidites Ross, 1949, p. 33.

Verrucatosporites Thomson and Pflug, 1953, p. 59.

Polypodiisporites Potonié, 1956, p. 78.

Remarks.—Jansonius and Hills (1976, card 2104) considered that Polypodiisporonites is a valid generic name despite the peculiar way in which it was first written. Potonié (1966, p. 103) united Polypodiidites, Verrucatosporites, and Polypodiisporites, considering them to be synonyms; Polypodiisporites and Polypodiisporonites have the same type species, $P$. favus Potonié, 1931c.

Polypodiisporonites afavus (Krutzsch) n. comb.

Plate 1, figure 5

Verrucatosporites afavus Krutzsch, 1959a, p. 209-210, pl. 41, figs. 460-462 (basionym).

Verrucatosporites sp. Tschudy and Van Loenen, 1970, pl. 1, fig. 2.

Remarks. -What Thomson and Pflug (1953, p. 60, pl. 3 , figs. 52-55; pl. 4, figs. 1-4) called Verrucatosporites favus (Potonié) Thomson and Pflug is not really $V$. favus but is probably Polypodiisporonites afavus. In $P$. afavus the verrucae are much smaller than in $P$. alienus ( $\mathrm{P}_{0}-$ tonié, 1931c) n. comb. and in $P$. favus Potonié, 1931c.

Affinity.-Probably Polypodiaceae, for instance, $M i$ crogramma.

Occurrence._- "Infrequent" in 33/56 counted samples from the upper part of the Claiborne Group to the lower part of the Vicksburg Group.

\section{Polypodiisporonites alienus (Potonié) n. comb.}

Plate 1, figure 2

Sporonites alienus Potonié, 1931c, p. 556, fig. 1 (basionym).

Verrucatosporites alienus (Potonié) Thomson and Pflug, 1953, p. 60, pl. 3, figs. 46-51. 
Polypodiisporites ef. P. favus R. Potonié, 1934. Engelhardt, 1964a, p. 70 , pl. 1 , fig. 7.

Polypodiumsporites sp. Fairchild and Elsik, 1969, p. 83, pl. 37, fig. 1. Verrucatosporites sp. Tschudy and Van Loenen, 1970, pl. 1, figs. 4-6. Verrucatosporites spp. Tschudy, 1973, p. B16, pl. 3, figs. 23-24.

Remarks. - In this species, the verrucae are high and pointed, and there is little or no negative reticulum; in Polypodiisporonites favus Potonié, 1931c, the verrucae are low and broadly rounded, and a negative reticulum is present.

Affinity.-Similar spores occur in Oleandraceae (for instance, Nephrolepis), Polypodiaceae (for instance, Phlebodium), and Pteridaceae.

Occurrence.-Present in 49/56 counted samples from the upper part of the Claiborne Group to the lower part of the Vicksburg Group; mostly "infrequent," but "occasional" in a few samples from the lower and middle parts of the Yazoo Clay. This species evidently ranges down to the lower part of the Claiborne Group but is more consistently present in the upper part of the Claiborne and above (Fairchild and Elsik, 1969, p. 83; Tschudy, 1973, p. B16).

\section{Polypodiisporonites favus Potonié}

Plate 1, figure 3.

Polypodii(?)-sporonites favus Potonié, 1931c, p. 556, fig. 3.

Verrucatosporites favus (Potonié) Thomson and Pflug, 1953, p. 60, pl. 3 , figs. 52-55; pl. 4, figs. $1-4$ [misidentified].

Polypodiisporites favus (Potonié) Potonié, 1956, p. 78.

Reticuloidosporites favus (Potonié) Krutzsch, 1959a, p. 215, pl. 42, figs. $467-470$.

Affinity.-Probably Polypodiaceae s. 1.

Occurrence._- "Infrequent" to "occasional" in $37 / 56$ counted samples from the upper part of the Claiborne Group to the lower part of the Vicksburg Group.

\section{Genus MICROFOVEOLATOSPORIS Krutzsch, 1959a}

Microfoveolatosporis pseudodentata Krutzsch

Plate 1, figure 4

Microfoveolatosporis pseudodentatus Krutzsch, 1959a, p. 212, pl. 41, figs. $463-466$.

Microfoveolatosporis ef. M. pseudodentatus Krutzsch, 1959. Engelhardt, 1964a, p. 69-70, pl. 1, fig. 6.

Microfoveolatosporis cf. M. pseudodentatus Engelhardt, 1964. Tschudy and Van Loenen, 1970, pl. 1, fig. 3.

Affinity.-Similar to Psilotum (Psilotaceae) according to Kedves (1969, p. 15, pl. 1, fig. 8) and Schizaea pusilla Pursh (Schizaeaceae) according to Engelhardt (1964a, p. 70).

Occurrence._- "Infrequent" in $27 / 56$ counted samples from the upper part of the Claiborne Group to the lower part of the Vicksburg Group. This species ranges down into the Paleocene (Elsik, 1968a, pl. 7, fig. 5).
Genus SCHIZAEA J. E. Smith

Schizaea tenuistriata (Pflanzl) n. comb.

Plate 1, figure 6

Cicatricososporites pseudodorogensis tenuistriatus Pflanzl, 1956, p. 239, pl. 16, fig. 5 (basionym).

Remarks. - The holotype of Cicatricososporites pseudodorogensis (pl. 4, fig. 13 in Thomson and Pflug, 1953) does not appear to have the forked lirae that are characteristic of S. tenuistriata. Krutzsch (1959a, p. 224) suggested that $C$. pseudodorogensis tenuistriatus be raised to species level.

Affinity.-Very similar to spores of Schizaea laevigata Mett. and S. penicillata Kunth.

Occurrence.-One specimen observed from the Moodys Branch Formation of eastern Mississippi.

Genus CONCAVISPORITES Phug in Thomson and Pflug, 1953

Concavisporites discites Pflug

Plate 1, figure 9

Concavisporites discites Pflug in Thomson and Pflug, 1953, p.49, pl. 1, fig. 24.

Affinity.-Possibly Gleicheniaceae.

Occurrence.-One specimen observed from the upper part of the Yazoo Clay of western Mississippi.

\section{Genus CYATHEA Smith}

Cyathea? stavensis (Frederiksen) n. comb.

Plate 1, figure 7

Concavisporites stavensis Frederiksen, 1973, p. 69, pl. 1, figs. 1-4 (basionym).

Remarks. - In this species, the inner surface of the exine has an irregular network of grooves, usually including one that is parallel to the outline.

Affinity. - Very similar in all respects to spores of $C y$ athea hildebrandtii Kühn illustrated by Tardieu-Blot (1966, p. 115, pl. 9, fig. 9).

Occurrence._- "Infrequent" in 16/56 counted samples from the upper part of the Claiborne Group to the lower part of the Vicksburg Group.

\section{Genus GLEICHENIIDITES Ross, 1949 emend. Skarby, 1964}

\section{Gleicheniidites senonicus Ross, 1949 emend. Skarby, 1964}

Plate 1, figure 8

Gleicheniidites senonicus Ross, 1949, p. 31, pl. 1, fig. 3

Gleicheniidites senonicus Ross, 1949, emend. Skarby, 1964, p. 65-67, text-fig. 1, pls. 1-3.

Gleicheniidites senonicus Ross, 1949. Engelhardt, 1964a, p. 69, pl. 1, fig. 2.

Gleicheniidites sp. Tschudy and Van Loenen, 1970, pl. 1, fig. 11. 
Affinity.-Gleicheniaceae, Gleichenia or Dicranopteris (Skarby, 1964, p. 62).

Occurrence._- "Infrequent" in 9/56 counted samples from the upper part of the Claiborne Group to the lower part of the Vicksburg Group, mostly in western Mississippi. The species ranges down into the Cretaceous (Ross, 1949).

\section{Genus LYGODIUM Swartz}

Lygodium labratum Frederiksen

Plate 1, figures 10-11

Lygodium? labratum Frederiksen, 1973, p. 69, pl. 1, figs. 5-10.

Remarks. - The exine in L. labratum is foveolate, and the rays have prominent labra.

Affinity.-No genus other than Lygodium (Schizaeaceae) appears to have spores of this type.

Occurrence.- "Infrequent" in 8 or $9 / 56$ counted samples from the upper part of the Claiborne Group to the lower part of the Vicksburg Group; not observed in samples from eastern Mississippi.

\section{Genus LYGODIUMSPORITES Potonié, 1956}

Lygodiunssporites adriennis (Potonié and Gelletich) Potonié

Plate 1, figures 12-13

Punctati-sporites adriennis Potonié and Gelletich, 1933, p. 521, pl. 2, figs. 14-15.

Lygodiumsporites adriennis (Potonié and Gelletich) Potonié, 1956, p. 19.

Leiotriletes adriennis (Potonie and Gelletich) Krutzsch, 1959a, p. 57.

Remarks.-Lygodiumsporites adriennis is a variable species and is here interpreted rather broadly as was done by Krutzsch (1959a). No attempt was made to break it into subspecies except for the form described as Lygodiumsporites? cf. L. adriennis.

Affinity.-Probably mainly Lygodium (Schizaeaceae). Occurrence.-Counted together with Lygodiumsporites? cf. L. adriennis, but $L$. adriennis makes up the great bulk of the specimens and is by far the most abundant of the psilate, trilete forms in the section studied; "infrequent" to "common" in nearly all samples.

Lygodiunisporites? cf. L. adriennis (Potonié and Gelletich, 1933) Potonié, 1956

Plate 1, figure 14

Cyathidites minor Couper, 1953 [misidentified]. Engelhardt, 1964a, p. $68-69$, pl. 1, fig. 1 .

Cyathidites sp. Tschudy and Van Loenen, 1970, pl. 1, fig. 7.

Description.-Size 34-55 $\mu \mathrm{m}$, mean $45 \mu \mathrm{m}$. Outline triangular, with slightly concave sides and broadly rounded corners; one side is often straight or slightly convex. Trilete; sutures open or closed; labra narrow if present at all; rays straight, $1 / 2-3 / 4$ radius, typically $2 / 3$ ra- dius. Exine about $1.5 \mu \mathrm{m}$ thick, on some specimens only $1 \mu \mathrm{m}$ thick; endexine very thin. Exine psilate to infrapunctate. Some specimens have a large infra?-punctate to infra?-granulate contact area (pl. 1, fig. 14).

Remarks.-In shape and length of rays, Lygodiumsporites? cf. L. adriennis has similarities to Lygodiumsporites adriennis, Cyathidites minor Couper, 1953, and Cardioangulina diaphana (Wilson and Webster, 1946) Stanley, 1965. Cyathidites minor has slightly more concave sides and longer rays on the average. Cardioangulina diaphana has shorter rays. Typical Lygodiumsporites adriennis has straight to slightly convex sides. It is difficult to distinguish consistently between Lygodiumsporites? cf. L. adriennis and L. adriennis, however, and both types were counted together.

Affinity.-Probably Cyatheaceae and (or) Lygodium (Schizaeaceae).

Occurrence. - Counted together with Lygodiumsporites adriennis, which is by far the more abundant species of the two. Lygodiumsporites? cf. L. adriennis appears to be more conspicuous in the lower part of the section studied (Cockfield, Gosport, Moodys Branch) than in the upper part. Few specimens were observed in the Forest Hill Sand, although typical $L$. adriennis is quite abundant in this formation.

\section{Genus TOROISPORIS Krutzsch, 1959a}

Toroisporis aneddenii Krutzsch

Plate 2, figure 1

Toroisporis aneddeni Krutzsch, 1959a, p. 98, pl. 10, figs. 75-76.

Remarks. - This species has a thick exine, rather narrowly rounded corners, and gently concave sides. In contrast, Toroisporis longitora Krutzsch, 1959a, has more or less straight sides and much more broadly rounded corners. In T. postregularis Krutzsch, 1959a, the tori wrap around the ends of the rays.

Affinity.-Adiantum (Adiantaceae), Gleichenia (Gleicheniaceae), and Cheiropleuria (Cheiropleuriaceae) all have similar spores.

Occurrence.-Two specimens observed from the Gosport Sand at Little Stave Creek.

\section{Toroisporis longitora Krutzsch}

Plate 2, figures $2-3$

Toroisporis longitorus Krutzsch, 1959a, p. 99-100, pl. 10, figs. 8084.

Affinity.-Unknown.

Occurrence. - "Infrequent" in 8/56 counted samples; observed only in the Yazoo Clay and Forest Hill Sand.

\section{Toroisporis postregularis Krutzsch}

Plate 2, figure 4

Toroisporis postregularis Krutzsch, 1959a, p. 98, pl. 10, figs. 77-78. 
Affinity.-Possibly Dicksonia (Cyatheaceae). Occurrence.-One specimen observed from the Moodys Branch Formation of eastern Mississippi.

\section{Genus CTENOPTERIS Blume}

Ctenopteris? elsikii (Frederiksen) n. conıb.

Plate 2, figure 5

Undulatisporites sp. Elsik, 1968a, p. 294, pl. 8, fig. 4; pl. 10, fig. 6.

Undulatisporites elsikii Frederiksen, 1973, p. 69-70, pl. 1, figs. 1112,18 (basionym).

Affinity. - The outline (convex to slightly concave sides and narrowly rounded corners) and the long, sinuous rays, with high, closed lips, are both very similar to spores of several species of Ctenopteris (Grammitidaceae) illustrated by Tardieu-Blot $(1966$, pl. 6 , figs. 1, 3). Modern Ctenopteris is typically verrucate to scabrate, though often only weakly so.

Occurrence. - "Infrequent" in 10 or $11 / 56$ counted samples from the upper part of the Claiborne Group to the lower part of the Vicksburg Group. Also reported by Elsik (1968a) from the Paleocene of Texas.

Genus UNDULATISPORITES Pflug in Thonison and Pflug, 1953

Undulatisporites concavus Kedves

Plate 2, figure 6

Undulatisporites concavus Kedves, 1961, p. 134, pl. 7, figs. 3-7.

Affinity.-Unknown.

Occurrence.- "Infrequent" to "occasional" in $8 / 56$ counted samples; observed only in the Yazoo Clay and Forest Hill Sand.

\section{Undulatisporites sp. \\ Plate 2, figure 7}

Description.-Size $30-37 \mu \mathrm{m}$ (two specimens). Outline round. Trilete, sutures closed; labra wavy, $0.5 \mu \mathrm{m}$ wide and $4 \mu \mathrm{m}$ high, extending $1 / 2-2 / 3$ radius. Exine about $1.5 \mu \mathrm{m}$ thick, densely though somewhat indistinctly granulate to verrucate.

Remarks.-Undulatisporites sp. is distinguished by its rather short rays and granulate to verrucate exine.

Affinity.-Unknown.

Occurrence.-Two specimens observed, one from the Yazoo Clay and one from the Forest Hill Sand of western Mississippi.

\section{Genus MONOLEIOTRILETES Krutzsch, 1959a}

Monoleiotriletes sp.

Plate 2, figure 8

Description.-Size $23 \times 24 \mu \mathrm{m}$ (one specimen). Outline more or less round. Trilete, rays about $1 / 3$ radius, bordered by slight lips. Exine $0.5 \mu \mathrm{m}$ thick, much folded, psilate.
Remarks.-Monoleiotriletes angustus Krutzsch, 1959a, is larger; $M$. gracilis Krutzsch, 1959a, is triangular in outline. Monoleiotriletes sp. is morphologically very similar to Paleozoic spores placed in Calamospora, but it does not look reworked.

Affinity.-Unknown.

Occurrence.-One specimen observed from the upper part of the Yazoo Clay of western Mississippi.

\section{Genus PUNCTATISPORITES Ibrahim, 1933}

Punctatisporites nicroadriennis (Krutzsch) n. comb.

Plate 2, figure 9

Leiotriletes microadriennis Krutzsch, 1959a, p. 61-62, pl. 1, figs. 37 (basionym).

Remarks._Krutzsch (1959a, p. 66-67) restricted Punctatisporites to punctate spores, that is, to spores having a rough or finely pitted outer surface of the exine. He placed smooth, round to triangular spores in Leiotriletes. I prefer to follow the custom established by Potonié and Kremp $(1954$, p. 120, 123), according to which round, psilate to punctate spores are placed in Punctatisporites and triangular, psilate to punctate spores are placed in Leiotriletes.

Affinity.-Unknown.

Occurrence. - "Infrequent" in 8/56 counted samples; observed only from the Moodys Branch Formation to the Forest Hill Sand of western and eastern Mississippi; may also occur in the Cockfield Formation.

\section{Genus GRANULATISPORITES Ibrahini, 1933 eniend. Potonié and} Kremp, 1954

Granulatisporites luteticus (Krutzsch) n. conb.

Plate 2, figure 13

Punctatisporites luteticus Krutzsch, 1959a, p. 68, pl. 4, figs. 25-26 (basionym).

Remarks. - The exine is granulate, not punctate, and thus the species belongs to Granulatisporites.

Affinity.-Very similar to spores of Acrostichum aureum L. (Pteridaceae) illustrated by Nayar and others (1964, pl. 1, fig. 65) and Kremp (1967, pl. 1, fig. 8).

Occurrence.-One specimen observed from the upper part of the Yazoo Clay of western Mississippi.

\section{Genus OSMUNDA Linnaeus}

Remarks. - The transfer of Baculatisporites primarius (Wolff, 1934) Thomson and Pflug, 1953, to Osmunda results in the genus Baculatisporites Pflug and Thomson (in Thomson and Pflug, 1953; type species B. primarius) becoming a synonym of Osmunda.

\section{Osnuunda prinıaria (Wolff) n. conb.}

Plate 2, figure 10

Sporites primarius Wolff, 1934, p. 66, pl. 5, fig. 8 (basionym). 
Baculatisporites primarius (Wolff) Thomson and Pflug, 1953, p. 56, pl. 2, figs. 49-53.

Osmundacidites wellmanii Couper, 1953 [misidentified]. Engelhardt, 1964a, p. 69, pl. 1, fig. 3 .

Osmundacidites sp. Tschudy and Van Loenen, 1970, pl. 1, figs. 8a-b.

Occurrence.- "Infrequent" in two samples of Yazoo Clay from western and eastern Mississippi, respectively. Also reported as being present in the Cockfield Formation and the Yazoo Clay of western Mississippi by Engelhardt (1964a) and Tschudy and Van Loenen (1970), respectively.

\section{Genus PTERIS Linnaeus \\ Pteris dentata (Nagy) n. comb.}

Plate 3, figures 5-6

Ornatisporites dentatus Nagy, 1963a, p. 146, 148, pl. 1, figs. 3-6 (basionym).

Affinity.-Similar to spores of a number of species of Pteris illustrated by Tardieu-Blot (1963, pls. 4, 6, 9).

Occurrence.-One specimen observed from the Yazoo Clay of western Mississippi.

\section{Genus BULLASPORIS Krutzsch, 1959a}

\section{Bullasporis sp. \\ Plate 2, figures 11-12}

Description.-Size including bullae 48-57 $\mu \mathrm{m}$ (two specimens). Outline triangular with convex sides and rather pointed corners. Trilete, rays somewhat indistinct, sutures closed, labra $0.5-1 \mu \mathrm{m}$ wide, rays slightly wavy, extending $2 / 3$ to nearly full radius. Exine about 0.5 $\mu \mathrm{m}$ thick, wrinkled on both faces, psilate on proximal face. Distal face and equator densely covered with anastomosing, thick bullae 3-17 $\mu \mathrm{m}$ in diameter and 8-11 $\mu \mathrm{m}$ high.

Remarks.-Bullasporis sp. is distinguished by the fact that both the distal face and the equator are covered by many bullae.

Affinity.-Unknown.

Occurrence. - Two specimens observed, one each from the Moodys Branch Formation of eastern Mississippi and the upper part of the Yazoo Clay of western Mississippi.

Genus CICATRICOSISPORITES Potonie and Gelletich, 1933 emend. Potonié, 1966

Cicatricosisporites dorogensis Potonié and Gelletich

Plate 3, figure 1

Cicatricosisporites dorogensis Potonié and Gelletich, 1933, p. 522, pl. 1, figs. 1-5.

Cicatricosisporites dorogensis R. Potonié and Gelletich, 1933. Engelhardt, 1964a, p. 69, pl. 1, fig. 4.

Remarks. - This species name has traditionally been used for spores in which the lirae are continuous, whereas
C. paradorogensis Krutzsch, 1959a, has been applied to similar spores in which the lirae are coarsely foveolate. Affinity.-Anemia or Mohria (Schizaeaceae).

Occurrence.- "Infrequent" to "common" in 40/56 counted samples from the upper part of the Claiborne Group to the lower part of the Vicksburg Group.

Cicatricosisporites embryonalis Krutzsch

Plate 3, figures 2-3

Cicatricosisporites embryonalis Krutzsch, 1959a, p. 174, pl. 36, figs. 376-378.

Remarks. - Spores of this species are smaller than those of $C$. dorogensis Potonié and Gelletich, 1933, and C. paradorogensis Krutzsch, 1959a, and the lirae are less distinct. Krutzsch (1959a, p. 174) pointed out that at least some fossil spores assigned to $C$. embryonalis may be immature.

Affinity.-Anemia or Mohria (Schizaeaceae).

Occurrence. - "Infrequent" in four counted samples from the Yazoo Clay of Mississippi and Alabama.

\section{Cicatricosisporites paradorogensis Krutzsch}

Plate 3, figure 4

Cicatricosisporites paradorogensis Krutzsch, 1959a, p. 172, pl. 35, figs. 366-371; pl. 36, figs. 372-373.

Cicatricosisporites cf. C. paradorogensis Krutzsch, 1959. Engelhardt, 1964 a, p. 69 , pl. 1 , fig. 5 .

Affinity.-Anemia or Mohria (Schizaeaceae).

Occurrence.- "Infrequent" to "common" in $44 / 56$ counted samples from the upper part of the Claiborne Group to the lower part of the Vicksburg Group.

\section{Genus LYCOPODIUM Linnaeus}

Lycopodium convexum (Frederiksen) n. comb.

Plate 3, figures 7-8

Favoisporis convexa Frederiksen, 1973, p. 70 and 72, pl. 1, figs. 1317 (basionym).

Affinity.-In its outline, smooth proximal face, and broken negative reticulum on the distal face, this species is very similar to spores of Lycopodium phlegmaria $\mathrm{L}$. illustrated by Nayar and Lata (1965, fig. 5).

Occurrence.- "Infrequent" in five counted samples from western Mississippi; the species ranges from the base to the top of the Yazoo Clay.

\section{Lycopodium hamulatum (Krutzsch) n. comb.}

Plate 3, figures 9-10

Hamulatisporis hamulatis Krutzsch, 1959a, p. 157-158, pl. 29, figs. 326-328 (basionym).

Camarozonosporites hamulatis (Krutzsch) Krutzsch, 1963, p. 23. 
Remarks. - This species has an exine of uniform thickness, whereas in L. heskemensis (Pflanzl in Mürriger and Pflanzl, 1955) n. comb., the exine is thicker along the sides than at the corners. L. hamulatum is the type species of the genus Hamulatisporis Krutzsch, 1959a (which was reduced to subgeneric rank under the genus Camarozonosporites Potonié, 1956, by Krutzsch, 1963); therefore, with the transfer of Hamulatisporis hamulatum [or Camarozonosporites (Hamulatisporis) hamulatum] to Lycopodium, Hamulatisporis becomes a synonym of Lycopodium.

Affinity.-Similar to Lycopodium inundatum $\mathrm{L}$.

Occurrence.- "Infrequent" in a sample of Gosport Sand from Little Stave Creek and a sample of Moodys Branch Formation from western Mississippi.

Lycopodium heskemensis (Pflanzl) n. comb.

Plate 3, figures 12-13

Cingulatisporites heskemensis Pflanzl in Mürriger and Pflanzl, 1955, p. 87 , pl. 5, figs. 1-3 (basionym).

Camarozonosporites heskemensis (Pflanzl) Krutzsch, 1959a, p. 187188, pl. 38, figs. 413-421.

Affinity.-Very similar to Lycopodium cernuum L.

Occurrence.- "Infrequent" in 21 or 22/56 counted samples from the upper part of the Claiborne Group to the lower part of the Vicksburg Group. In eastern Mississippi and western Alabama, the species occurs mostly in the Gosport Sand, Moodys Branch Formation, and lower part of the Yazoo Clay.

\section{Lycopodium venustum Frederiksen}

Plate 3, figure 11

Lycopodium venustum Frederiksen, 1973, p. 72, pl. 1, figs. 19-21.

Remarks.-The distinguishing features of this species are the delicate continuous muri and the very small triangular thickenings at the intersections of the muri.

Occurrence. - "Infrequent" in seven counted samples from the lower part of the Yazoo Clay to the lower part of the Vicksburg Group.

\section{Genus SELAGINELLA Beauvoís}

Selaginella perinata (Krutzsch and others) n. comb.

\section{Plate 3, figures 14-15}

Lusatisporis perinatus Krutzsch and others, 1963, p. 98, pl. 30, figs. 10-11 (basionym).

Selaginella sinuites Martin and Rouse, 1966, p. 185-186, pl. 1, figs. $7-8$.

Remarks.-In this species a loose, much-folded, granulate "saccus" having distinct trilete rays surrounds a psilate "central body."
Occurrence.- "Infrequent" to "occasional" in $35 / 56$ counted samples from the upper part of the Claiborne Group to the lower part of the Vicksburg Group.

\section{Selaginella sp. A \\ Plate 4, figures 2-6}

Description.-Size excluding ornamentation, 24-30 $\mu \mathrm{m}$ (three specimens). Outline rounded triangular; trilete, sutures closed, labra 0.7-1.5 $\mu \mathrm{m}$ wide, wavy to nearly straight, extending $2 / 3-3 / 4$ radius. Exine probably about $1 \mu \mathrm{m}$ thick on proximal and distal faces, having irregular thickened zone (cingulum) $1-3 \mu \mathrm{m}$ wide around equator. Proximal and distal faces densely punctate to granulate. Distal face also with scattered, thick clavae, short baculae, and tuberculae, the elements $1.5-3 \mu \mathrm{m}$ in diameter and 1-4 $\mu \mathrm{m}$ high. Scattered coni (10-20 of them) project from the equator; they are $1-3 \mu \mathrm{m}$ in diameter and 0.5-1.5 $\mu \mathrm{m}$ high.

Remarks. - Selaginella sp. A differs from similar, previously described form species that have been placed in the form genus Muerrigerisporis Kurtzsch and others, 1963 , by having mainly rounded elements (clavae, etc.) rather than spines and coni, and by the fact that these elements are only on the distal face and not on both faces.

Affinity.-Similar to spores of Selaginella biformis Al. Braun and S. flagellata Spring, illustrated by Erdtman (1957, figs. 176, 178).

Occurrence.-Known only from the Gosport Sand and the Yazoo Clay.

\section{Selaginella sp. B}

Plate 4, figures 7-10

Description.-Size 35-42 $\mu \mathrm{m}$ (two specimens). Outline triangular with convex to nearly straight sides. Trilete, sutures closed, labra $0.5-1 \mu \mathrm{m}$ thick and 1.5-3 $\mu \mathrm{m}$ high, straight to slightly wavy, extending $2 / 3-3 / 4$ radius. Exine 3-4 $\mu \mathrm{m}$ thick, distinctly infrabaculate in optical section; proximal face punctate to indistinctly reticulate in design and lacking coni; distal face distinctly reticulate, with lumina about $1 \mu \mathrm{m}$ in diameter and muri about $0.5 \mu \mathrm{m}$ wide; distal face also with scattered, pointed to rounded, pitted coni $2.5-5.5 \mu \mathrm{m}$ in diameter and $2-3 \mu \mathrm{m}$ high; equator thickly set with a ring of spines which vary from pointed to blunt to clavate, $\mathbf{3}-\mathbf{5 . 5} \mu \mathrm{m}$ in diameter and 4-6.5 $\mu \mathrm{m}$ high, slightly bulbous and pitted near the base.

Remarks.—Selaginella sp. B is similar to previously described form species placed in the form genus Pustechinosporis Krutzsch, 1959a, but it is distinguished by its triangular to rounded triangular outline and lack of coni on the proximal face.

Occurrence.-Two specimens observed in a sample from the upper part of the Yazoo Clay of western Mississippi. 
Genus SPHAGNUM (Dill.) Ehrh.

Sphagnum antiquasporites Wilson and Webster

Plate 4, figure 11

Sphagnum antiquasporites Wilson and Webster, 1946, p. 273, fig. 2. "Triletes psilatus" Ross, 1949, p. 32, pl. 1, fig. 12.

Stereisporites psilatus Ross ex Thomson and Pflug, 1953, p. 53, pl. 1, figs. $75-80$.

Sphagnumsporites antiquasporites (Wilson and Webster) Potonié, 1956, p. 17.

Remarks.-Spores of Sphagnum antiquasporites are small and have a narrow cingulum and short rays.

Occurrence.-Counted together with Sphagnum australum, S. stereoides, and Stereisporites woelfersheimensis. Sphagnum antiquasporites is "infrequent" in scattered samples; it probably ranges from the upper part of the Claiborne Group to the lower part of the Vicksburg Group.

\section{Sphagnum australum (Cookson) $n$. comb.}

Plate 4, figure 12

Triletes australis Cookson, 1947, p. 136, pl. 15, figs. 58-59 (basionym).

Sphagnites australis (Cookson) Cookson, 1953, p. 464.

Sphagnumsporites australis (Cookson) Potonié, 1956, p. 17, pl. 1, fig. 8.

Stereisporites australis (Cookson) Krutzsch, 1959a, p. 71.

Remarks. Sphagnum australum, Sphagnum stereoides (Potonié and Venitz, 1934) Martin and Rouse, 1966, Stereisporites megastereoides Pflug in Thomson and Pflug, 1953, and Stereisporites woelfersheimensis Krutzsch, 1959a, are all about the same size and all have long rays, but the cingulum in the latter two species is broad, that in Sphagnum australum is intermediate in width, and Sphagnum stereoides has a narrow cingulum.

Occurrence.-Counted together with Sphagnum antiquasporites, S. stereoides, and Stereisporites woelfersheimensis. Sphagnum australum is "infrequent" in scattered samples probably from the upper part of the Claiborne Group to the lower part of the Vicksburg Group. It is less common than Sphagnum antiquasporites.

\section{Sphagnum stereoides (Potonié and Venitz) Martin and Rouse}

Plate 4, figure 13

Sporites stereoides Potonié and Venitz, 1934, p. 11-12, pl. 1, figs. 4-5. Stereisporites stereoides (Potonié and Venitz) Thomson and Pflug, 1953 , p. 53, pl. 1, figs. 64-73.

Sphagnumsporites stereoides (Potonié and Venitz) Potonié, 1956, p. 17. Sphagnum stereoides (Potonié and Venitz) Martin and Rouse, 1966, p. 184, pl. 1, fig. 3 .

Occurrence.-Counted together with Sphagnum antiquasporites, S. australum, and Stereisporites woelfersheimensis. Sphagnum stereoides is rather rare in my material and is known definitely only from the Forest Hill Sand.

\section{Sphagnum triangularum (Mamczar) n. comb.}

Plate 4, figure 14

cf. Sphagnum-Sporites stereoides forma triangularis Mamczar, 1960, p. 196, pl. 1, fig. 3 (basionym).

Stereisporites triangularis (Mamczar) Krutzsch and others, 1963, p. 54, pl. 9, figs. 15-19.

Remarks. -This species is distinguished from Sphagnum antiquasporites Wilson and Webster, 1946, by having a triradiate thickening on the distal side.

Occurrence.- "Infrequent" in 6/56 counted samples; known only from the Moodys Branch Formation to the Forest Hill Sand in western and eastern Mississippi.

\section{Genus STEREISPORITES Pflug in Thomson and Pflug, 1953}

Remarks. - The synonymy of this genus was discussed by Krutzsch and others (1963, p. 9).

\section{Stereisporites megastereoides Pflug}

Plate 4, figure 1

Stereisporites megastereoides Pflug in Thomson and Pflug, 1953, p. 53, pl. 1, fig. 74 .

Sphagnumsporites megastereoides (Pflug) Potonié, 1956, p. 17.

Occurrence.- "Infrequent" in two samples of Yazoo Clay from western Mississippi.

\section{Stereisporites woelfersheimensis Krutzsch}

Plate 4, figure 15

Stereisporites woelfersheimensis Krutzsch, 1959a, p. 72.

Stereisporites stictus woelfersheimensis (Krutzsch) Krutzsch and others, 1963 , p. 50, pl. 7, figs. 13-16.

\section{Affinity.-Possibly Sphagnum.}

Occurrence.-Counted together with Sphagnum antiquasporites, S. australum, and S. stereoides. In my material, Stereisporites woelfersheimensis is rather rare and is definitely known only from the Yazoo Clay of western Mississippi.

\section{Genus PODOCARPUS Persoon \\ Podocarpus? cappulatus n. name Plate 4, figures $17-18$}

Podocarpus andiniformis Zaklinskaya, 1957, p. 105, pl. 2, figs. 3-7 (basionym), not Podocarpus andiniformis Bolkhovitina, 1956.

ef. Podocarpus forma libella Doktorowicz-Hrebnicka, 1960, pl. 29, fig. 59.

cf. Podocarpus forma unica Doktorowicz-Hrebnicka, 1960, pl. 29, fig. 60.

Podocarpus sp. Rouse, 1962, p. 201, pl. 1, fig. 18.

Abietineaepollenites ef. A. microalatus (R. Potonié, 1934) R. Potonié, 1951. Engelhardt, 1964a, p. 70, pl. 1, fig. 9.

Abietineaepollenites sp. (Diploxylon type). Tschudy and Van Loenen, 1970, pl. 2, ?fig. 9. 
Remarks. - In this species, the body wall is thin; the wings are only slightly wider than the body and nearly meet each other at the equator. Kremp and others (1960, p. 10-157) pointed out that Podocarpus andiniformis Zaklinskaya, 1957, is a homonym of $P$. andiniformis Bolkhovitina, 1956. Podocarpus? cappulatus is here proposed as a new name for Zaklinskaya's species. The name refers to the well developed cappula in these grains.

Affinity.-In the arrangement and the relative sizes of body and wings, this species is similar to Podocarpus standleyi Buchh. and Gray and P. acutifolius T. Kirk. However, in these and in most other species of Podocarpus, the body sexine is very thick, whereas it is unusually thin in P.? cappulatus. In pollen grains of Cedrus, the wings are slightly wider than the body but are set rather far apart; as in Podocarpus, the body sexine is thick. In short, an affinity with Podocarpus is more likely than with Cedrus, bit. because of the thin body exine in the fossil species, it cannot be assigned with certainty to Podocarpus.

Occurrence.- "Infrequent" in $24 / 56$ counted samples from the upper part of the Claiborne Group to the lower part of the Vicksburg Group.

\section{Podocarpus maximus Stanley}

Plate 4, figure 16

Podocarpus maximus Stanley, 1965, p. 281, pl. 41, figs. 1-8.

Remarks. -This species has wings that are sylvestroid and considerably wider than the body. The sexine of the body is cavate and wrinkled, the wrinkles forming rugulate patterns in plan view.

Affinity.-The wrinkled body sexine and the large size of the wings relative to the body are typical of many species of Podocarpus. In Cedrus, the body exine is also thick, but it is not cavate. Furthermore, in Cedrus grains, the proximal roots of the wings characteristically merge with the body sexine; that is, no sylvestroid indentation is present at the proximal roots as in $P$. maximus.

Occurrence. - "Infrequent" in 23/56 counted samples from the upper part of the Claiborne Group to the lower part of the Vicksburg Group.

Genus PITYOSPORITES Seward, 1914 emend. Manum, 1960

Pityosporites Seward, 1914, p. 23-24, pl. 8, fig. 45.

Pinus-pollenites Raatz, 1937, p. 15-16, pl. 1, fig. 12.

Pityosporites Seward emend. Potonié and Klaus, 1954, p. 534-536, pl. 10 , figs. $6-10$.

Pinuspollenites Raatz ex Potonié, 1958, p. 62, pl. 8, figs. 75-76.

Pityosporites Seward emend. Manum, 1960, p. 14-15, pl. 1.

Pityosporites longifoliaformis (Zaklinskaya) Krutzsch

Plate 5, figures 1-2

Pinus longifoliaformis Zaklinskaya, 1957, p. 153, pl. 13, figs. 7-9.

Pinus ponderosaeformis Zaklinskaya, 1957, p. 153-154, pl. 13, figs. 10-14.
Abietineaepollenites (Diploxylon type). Tschudy and Van Loenen, 1970, pl. 2, fig. 14.

Pityosporites longifoliaformis (Zaklinskaya) Krutzsch, 1971, p. 16. Pityosporites ponderosaeformis (Zaklinskaya) Krutzsch, 1971, p. 17.

Remarks.-Zaklinskaya's species Pinus longifoliaformis and $P$. ponderosaeformis are very similar to each other and intergrade. In this species, the wings are distinctly sylvestroid but are only slightly wider than the body; the sexine of the body is verrucate but not cavate as in Podocarpus maximus Stanley, 1965.

Affinity.-Probably Pinus; possibly Podocarpus. In Cedrus, the wings are slightly wider than the body and are set rather far apart as in these fossils, but no sylvestroid notch is present at the proximal contacts of the body and wings. In Keeteleria, the wings are set far apart and are distinctly sylvestroid, but they are less wide than the body, and the overall length of the grain is about $140 \mu \mathrm{m}$, much larger than the fossils; grains of Keeteleria are most similar to those of Abies.

Occurrence.- "Infrequent" in 15/56 counted samples from the upper part of the Claiborne Group to the lower part of the Vicksburg Group.

\section{Genus PINUS Linnaeus}

Pinus cembraeformis Zaklinskaya

Plate 5, figures $3-4$

Pinus cembraeformis Zaklinskaya, 1957, p. 142-143, pl. 10, figs. 813.

Pityosporites cembraeformis (Zaklinskaya) Krutzsch, 1971, p. 16.

Remarks. - The body exine in this species is verrucate but thinner than in Pityosporites longifoliaformis (Zaklinskaya, 1957) Krutzsch, 1971, and the wings are haploxylonoid to very slightly sylvestroid.

Occurrence. - "Infrequent" in $8 / 56$ counted samples from the upper part of the Claiborne Group to the lower part of the Vicksburg Group.

\section{Pinus labdaca (Potonié) n. comb.}

Plate 5, figure 6

Pollenites labdacus Potonié, 1931b, p. 5, fig. 32 (basionym).

Pityosporites labdacus (Potonié) Thomson and Pflug, 1953, p. 68, pl. 5 , figs. $60-62$.

Abietineaepollenites sp. (Diploxylon type). Tschudy and Van Loenen, 1970, pl. 2, fig. 7 .

Remarks.-In Pinus labdaca, the wings are distinctly sylvestroid, only slightly wider than the body; the cappula is wide, and the body exine is punctate and rather thin.

Occurrence._-Infrequent" to "occasional" in 51/56 counted samples. 


\section{Pinus tenuextima Traverse}

Plate 5, figure 5

Pinus tenuextima Traverse, 1955, p. 41, fig. 8 (13-14).

Remarks. - This form is haploxylonoid, and the body exine is thin and punctate.

Occurrence. - "Infrequent" to "common" in 53/56 counted samples.

\section{Genus PICEA A. Dietrich}

\section{Picea grandivescipites Wodehouse}

Plate 5, figure 7; plate 6, figure 1

Picea grandivescipites Wodehouse, 1933, p. 488, fig. 10. ?Piceapollis grandivescipites (Wodehouse) Krutzsch, 1971, p. 22.

Occurrence._- "Infrequent" in 16 or $17 / 56$ counted samples from the upper part of the Claiborne Group to the lower part of the Vicksburg Group.

\section{Genus CEDRUS Trew}

\section{Cedrus piniformis Zaklinskaya}

Plate 6, figures $2-3$

Cedrus piniformis Zaklinskaya, 1957, p. 134, pl. 9, figs. 1-4. Abietineaepollenites sp. (Diploxylon type). Tschudy and Van Loenen, 1970 , pl. 2, figs. ?4, 8 .

Cedripites piniformis (Zaklinskaya) Krutzsch, 1971, p. 24.

Remarks. - In this species, the wings are slightly less wide than the body and are set far apart.

Occurrence. - "Infrequent" in 8/56 counted samples; observed in samples only from the Moodys Branch Formation to the lower part of the Vicksburg Group of western and eastern Mississippi.

\section{Genus TSUGA Carriere \\ Tsuga ignicula (Potonié) n. comb. \\ Plate 6, figures 4-5}

Sporonites igniculus Potonié, 1931c, p. 556, fig. 2 (basionym).

Zonalapollenites igniculus (Potonié) Thomson and Pflug, 1953, p. 6667, pl. 4, figs. 75-79.

Tsugaepollenites igniculus (Potonié) Potonié, 1958, p. 48, pl. 6, fig 51.

Affinity. - “Tsuga diversifolia-Typ" of Rudolph (1936, p. 256, pl. 3, figs. 8-9).

Occurrence. - "Infrequent" in two samples of Yazoo Clay from western Mississippi.

\section{Genus SEQUOIAPOLLENITES Thiergart, 1938}

\section{Sequoiapollenites lapillipites (Wilson and Webster) Krutzsch}

Plate 6, figure 7

Sequoia lapillipites Wilson and Webster, 1946, p. 275, fig. 9. Sequoiapollenites lapillipites (Wilson and Webster) Krutzsch, 1971, p. 45.

Affinity. - This species could represent Sequoia, Metasequoia, or Cryptomeria. (Taxodiaceae).
Occurrence. - "Infrequent" in three counted samples; observed only in samples from the Moodys Branch Formation to the lower part of the Vicksburg Group in western and eastern Mississippi.

\section{Genus CUPRESSACITES Bolkhovitina, 1956}

Cupressacites hiatipites (Wodehouse) Krutzsch

Plate 6, figure 6

Taxodium hiatipites Wodehouse, 1933, p. 493, fig. 17.

Taxodiaceaepollenites hiatus (R. Potonié, 1931) Kremp, 1949 [misidentified]. Engelhardt, 1964a, p. 71, pl. 1, fig. 10.

Inaperturopollenites ef. I. hiatus (R. Potonié) Thomson and Pflug 1953. Tschudy and Van Loenen, 1970, pl. 2, figs. 5-6.

Cupressacites hiatipites (Wodehouse) Krutzsch, 1971, p. 41.

Remarks.-This species includes the grains that most authors have assigned to Inaperturopollenites hiatus (Potonié, 1931b) Thomson and Pflug, 1953. Originally, Potonié (1931b, p. 5) described Pollenites hiatus as being granulate to weakly reticulate, but the holotype appears to have a smooth surface. In later publications, Potonié (1934, p. 47, pl. 1, fig. 30, pl. 6, fig. 4; Potonié and Venitz, 1934 , p. 69 , pl. 5, fig. 29) emphasized that although the grains were flecked in design, the surface was smooth. Therefore I agree with Krutzsch $(1971$, p. 202) that the common, rough-surfaced, split taxodiaceous grains of the Upper Cretaceous and Cenozoic do not belong to I. hiatus. However, by assigning Pollenites hiatus to Inaperturopollenites, Krutzsch implied that grains of that species have a ligula. No evidence exists in the papers of Potonié (1931b, 1934; Potonié and Venitz, 1934) that a ligula is present, and therefore, Pollenites hiatus, like Taxodium hiatipites, should be assigned to Cupressacites.

Affinity.-Probably Taxodium or Glyptostrobus (Taxodiaceae).

Occurrence. - "Infrequent" to "occasional" in 18 or 19/56 counted samples from the upper part of the Claiborne Group to the lower part of the Vicksburg Group.

\section{Genus EPHEDRA Linnaeus}

\section{Ephedra claricristata Shakhmundes}

Plate 7, figures 2-3

Ephedra claricristata Shakhmundes, 1965, p. 226-227, fig. 10.

Ephedra eocenica Shakhmundes, 1965, p. 219-220, figs. 2-3.

Ephedripites (Distachyapites) tertiarius Krutzsch, 1970a, p. 156, 158, fig. 20; pl. 44, figs. 1-21.

Gnetaceaepollenites eocenipites (Wodehouse, 1933) R. Potonié, 1958 [misidentified]. Engelhardt, 1964a, p. 70, pl. 1, fig. 8.

Ephedra sp. (distachya-type). Fairchild and Elsik, 1969, p. 83, pl. 37, fig. 2.

Ephedra sp. (type A of Steeves and Barghoorn 1959). Tschudy and Van Loenen, 1970, pl. 1, fig. 13.

Ephedra type A of Steeves and Barghoorn, 1959. Tschudy, 1973, p. B17, pl. 4, figs. 22-23.

Remarks.-Krutzsch (1970a, p. 160) combined two of the species of Shakhmundes (1965)-Ephedra eocenica 
and $E$. claricristata-and considered the latter to be the senior synonym. He gave a size range of $33-45 \mu \mathrm{m}$ for this enlarged species. He then described a new species, Ephedripites tertiarius, which appears to differ from the redescribed Ephedra claricristata only in having a size range of $45-55 \mu \mathrm{m}$. However, according to the original definitions of Shakhmundes (1965), Ephedra claricristata and $E$. eocenica had size ranges of $33-38 \mu \mathrm{m}$ and 40-52 $\mu \mathrm{m}$, respectively. The size of Ephedripites tertiarius is within the size range of the enlarged species $E$. claricristata, and therefore I consider all three species to be synonyms of each other. My specimens range from 30 to $56 \mu \mathrm{m}$ in length and have four to six ribs. Ephedra eocenipites Wodehouse, 1933, is larger and has a size range of $57-74 \mu \mathrm{m}$. Some specimens that I counted as $E$. claricristata have a length:width ratio of considerably more than 2:1 (the illustrated specimen of Tschudy and Van Loenen (1970, pl. 1, fig. 13) has a length:width ratio of 2.6:1, and that of Engelhardt (1964a, pl. 1, fig. 8) has a ratio of $3: 1$, and theoretically these specimens should be assigned to Ephedra fusiformis Shakhmundes, 1965.

Occurrence._"Infrequent" to "occasional" in $48 / 56$ counted samples from the upper part of the Claiborne Group to the lower part of the Vicksburg Group. This species has the base of its range in the lower part of the Claiborne (Fairchild and Elsik, 1969, p. 83), but it probably does not become consistently present until the top of the Claiborne (Tschudy, 1973, p. B17).

\section{Ephedra exiguua n. sp.}

Plate 7, figure 1

Gnetaceaepollenites sp. (Ephedra distachya type). Engelhardt, 1964a, p. 70 , pl. 1, fig. 11 .

Description.-This species is identical with Ephedra cheganica Shakhmundes, 1965, except that the latter is 56-59 $\mu \mathrm{m}$ in size, whereas $E$. exiguua is $26-40 \mu \mathrm{m}$ (holotype, $26 \mu \mathrm{m}$ ). Like $E$. cheganica, the specimens from the Jackson Group and adjacent strata are thick walled and unfolded, and the grooves have secondary branches. It is also characteristic of the gulf coast specimens that the secondary grooves from adjacent furrows meet at the tops of the ridges, so that the crests of the ridges are never flat but are cut by a series of notches formed by the secondary grooves.

Holotype.-Plate 7, figure 1, slide 10556 A-1, coordinates $25.3 \times 113.6$, Gosport Sand at Little Stave Creek, Clarke County, Ala.

Remarks. - The specific epithet is Latin for "small." Ephedripites lusaticus Krutzsch, 1961, is thin walled but similar in other respects.

Occurrence._-"Infrequent" in 19 or 20/56 counted samples from the upper part of the Claiborne Group to the lower part of the Vicksburg Group.
Ephedra hungarica (Nagy) n. comb.

Plate 7, figure 4

Ephedripites hungaricus Nagy, 1963b, p. 278, figs. 1-3, 12A (basionym).

Remarks. - The ridges, furrows, and fine grooves in this species range from straight to slightly undulating. Nagy found one specimen measuring $19 \times 47 \mu \mathrm{m}$. My specimens are 28-55 $\mu \mathrm{m}$ in length, and their length:width ratios range from $1.9: 1$ to $3.0: 1$.

Occurrence. - "Infrequent" to "occasional" in 16/56 counted samples from the upper part of the Claiborne Group to the lower part of the Vicksburg Group.

Ephedra? laevigataeformis (Bolkhovitina) n. comb.

Plate 7, figure 5

Schizaea laevigataeformis Bolkhovitina, 1961, p. 29-30, pl. 6, figs. 1a-e (basionym).

Ephedra voluta Stanley, 1965, p. 284-285, pl. 40, figs. 10-11.

Occurrence. - "Infrequent" in 5/56 counted samples; observed only from the Moodys Branch Formation and Yazoo Clay of western and eastern Mississippi. Possibly these specimens are reworked, because the species has previously been reported mainly from the Upper Cretaceous and Paleocene. Fairchild and Elsik (1969, p. 84) reported that the species "ranges from the Upper Cretaceous up through the Lower Tertiary [of the gulf coast]. It is most common in the uppermost Cretaceous and Midway and lower Wilcox sequence."

\section{Genus GRAMINIDITES Cookson, 1947}

Remarks. -According to Krutzsch (1970a, p. 12), little if any difference exists between the genera Monoporopollenites Meyer, 1956, and Graminidites.

Graminidites gramineoides (Meyer) Krutzsch

Plate 7, figure 6

Monoporopollenites gramineoides Meyer, 1956, p. 111, pl. 4, fig. 29. Graminidites gramineoides (Meyer) Krutzsch, 1970a, p. 15.

Graminidites spp. Tschudy, 1973, p. B17, pl. 4, figs. 34-35.

Description.-Size of my specimens (mean of long and short dimensions), 19-36 $\mu \mathrm{m}$, mean $30 \mu \mathrm{m}$. Exine, 0.3$0.5 \mu \mathrm{m}$ thick, considerably folded, usually crushed to an oval shape; nearly psilate but faintly punctate, granulate, or verrucate; outline nearly smooth. Diameter of pore (of average-sized specimens) $1.7-2.5 \mu \mathrm{m}$; width of annulus $2.5-3 \mu \mathrm{m}$.

Remarks.-Krutzsch (1970a, p. 15) pointed out that the original description and photomicrograph of Graminidites gramineoides are not clear enough to be sure of the morphology of the species. However, the Jackson specimens are more like Meyer's species than any other and could well be conspecific. Graminidites gracilis Krutzsch, 1970a, is smaller and more sharply punctate. 
Affinity.-Gramineae.

Occurrence. - "Infrequent" in 8/56 counted samples from the upper part of the Claiborne Group to the lower part of the Vicksburg Group.

Genus MILFORDIA Erdtman, 1960 eniend. Krutzsch, 1970a

Milfordia Erdtman, 1960, p. 46.

Monulcipollenites Fairchild in Stover and others, 1966, p. $2-3$.

Restioniidites Elsik, 1968a, p. 313.

Milfordia Erdtman emend. Krutzsch, 1970a, p. 18.

Milfordia incerta (Pflug and Thomison) Krutzsch

Plate 7, figure 7

Inaperturopollenites incertus foveolatus Pflug and Thomson in Thomson and Pflug, 1953, p. 66, pl. 5, figs. 31-35.

Milfordia hypolaenoides Erdtman, 1960, p. 46-47, pl. 1, fig. a.

Milfordia incerta (Pflug and Thomson) Krutzsch, 1961, p. 325.

Restionaceae. Fairchild and Elsik, 1969, p. 83, pl. 37, fig. 5.

Remarks.-Taxonomy of this species was discussed by Krutzsch (1961, p. 325 and 1970 a, p. 72, 74). In contrast to the ulcus in Milfordia minima Krutzsch, 1970a, and in M. hungarica (Kedves, 1965) Krutzsch, 1970a, the ulcus in this species is highly irregular in shape and has rough or even beaded edges.

Affinity.-Centrolepis (Centrolepidaceae) or Restionaceae.

Occurrence._-"Infrequent" to "occasional" in nine counted samples; it ranges from the Gosport Sand only to the top of the Yazoo Clay. Reported from the Claiborne Group by Fairchild and Elsik (1969, p. 83).

\section{Milfordia mininia Krutzsch}

Plate 7, figure 8

Milfordia minima Krutzsch, 1970a, p. 76, pl. 10, figs. 4-34.

Monulcipollenites ef. $M$. confossus Fairchild in Stover, Elsik and Fairchild 1966. Tschudy and Van Loenen, 1970, pl. 2, figs. 12a-b.

Restio sp. Machin, 1971, pl. 2, fig. 14.

Remarks.-This species is smaller than Milfordia hungarica (Kedves, 1965) Krutzsch, 1970a; my specimens are $21-32 \mu \mathrm{m}$ in size.

Affinity.-Joinvillea (Flagellariaceae) and several genera of the Restionaceae have similar pollen grains.

Occurrence. - "Infrequent" in 5/56 counted samples; observed only in samples from the Moodys Branch Formation to the lower part of the Vicksburg Group.

Genus AGLAOREIDIA Erdtman, 1960, emend. Fowler, 1971

\section{Aglaoreidia cyclops Erdtman}

Plate 7, figures 9-10

Aglaoreidia cyclops Erdtman, 1960, p. 47, pl. 1, figs. b-c. Monoporopollenites sp. A. Machin, 1971, pl. 2, fig. 15.

Remarks.-The photomicrograph does not show it well, but a fine reticulum does wrap around the ends of the grain in the specimen from my material (pl. 7, figs.
9-10). In Aglaoreidia cyclops, the reticulum is coarse over much of the poriferous face and fine elsewhere, whereas in A. pristina Fowler, 1971, the maximum size of the lumina is found at the ends of the grain.

Affinity.-Monocotyledonous, possibly Ruppiaceae or Potamogetonaceae according to Machin (1971, p. 856).

Occurrence.-Counted together with Aglaoreidia pristina Fowler; refer to that species.

\section{Aglaoreidia pristina Fowler}

Plate 7, figure 11

Aglaoreidia pristina Fowler, 1971, p. 141-142, pl. 1, figs. 1-2. Monoporopollenites sp. B. Machin, 1971, pl. 2, fig. 16.

Occurrence.-In my samples containing Aglaoreidia, the genus does not have a relative frequency of more than $1 / 100$, and in most samples, its relative frequency is less than $1 / 10,000$ (no more than a few specimens on a rich slide). Aglaoreidia cyclops and A. pristina were originally counted together. Later, specimens of the genus were relocated; 10 of these were from zone II, and all 10 were of $A$. pristina. The single specimen from below zone II was from the Gosport Sand at Little Stave Creek and proved to be $A$. cyclops. This stratigraphic distribution is interesting because Fowler (1971) showed that in southern England the local range zone of $A$. $c y$ clops is above that of $A$. pristina; both are within the upper Eocene. The opposite seems to be true in the gulf coast, where $A$. pristina ranges from the uppermost Eocene into the Oligocene and $A$. cyclops has been definitely recorded as being from only the upper middle Eocene.

Genus MOMIPITES Wodehouse, 1933, emend. Nichols, 1973

\section{Momipites coryloides Wodehouse \\ Plate 7, figures 12-14}

Momipites coryloides Wodehouse, 1933, p. 511, fig. 43.

Engelhardtia sp. Fairchild and Elsik, 1969, p. 83, pl. 37, figs. 8-9.

?Momipites sp. (See M. coryloides Wode. 1933, in Engelhardt 1964). Tschudy and Van Loenen, 1970, pl. 2, fig. 15.

Triatriopollenites sp. Tschudy and Van Loenen, 1970, pl. 3, figs. 1-2.

Triatriopollenites $\mathrm{sp}$. of the T. coryphaeus type $(20 \mu-30 \mu)$. Tschudy, 1973 , p. B16, pl. 4, figs. 12-13.

Remarks. - In most samples from the upper part of the Claiborne Group to the lower part of the Vicksburg Group, about 5-30 percent of the specimens of Momipites coryloides have one, or sometimes two, white streaks across the grain (pl. 7, figs. 13-14) that look superficially like the pseudocolpi in grains of Platycarya. However, in $M$. coryloides, the white streaks are generally less numerous than in Platycarya, and the streaks are usually short, only half the grain's diameter or less. Furthermore, the white streaks are almost always bordered by folds, and at least in some grains, the white line next to a fold is an optical phenomenon like a Becke line and is 
not really a thin streak. Such a phenomenon appears, for instance, in the photomicrograph of the holotype of $E n$ gelhardtia spackmaniana Traverse (1955, fig. 9 (27)) and in the illustration of Pollenites coryphaeus tetraexituum in Potonié and Venitz (1934, pl. 2, fig. 35).

Affinity.-Engelhardtia group of the Juglandaceae (Engelhardtia, Oreomunnea, Alfaroa, and extinct but related genera). Most grains of Momipites coryloides are more like the Oreomunnea type than the Engelhardtia s. $s$. or Alfaroa types (refer to Kuprianova, 1965, pls. 27-28).

Occurrence._- "Infrequent" to "abundant" in every sample; relatively less abundant in the uppermost part of the Yazoo Clay, Forest Hill Sand, and Red Bluff Clay than lower in the section studied here.

\section{Momipites microfoveolatus (Stanley) Nichols \\ Plate 7, figures 15-16}

Engelhardtioidites ef. E. microcoryphaeus (R. Potonié, 1931) Potonié, Thomson, and Thiergart, 1950. Engelhardt, 1964a, p. 76-77, pl. 4, fig. 44.

Engelhardtia microfoveolata Stanley, 1965, p. 300-301, pl. 45, figs. 813.

Triatriopollenites sp. of the T. coryphaeus type $(13 \mu-18 \mu)$. Tschudy, 1973, p. B16, pl. 4, figs. 1-3.

Momipites microfoveolatus (Stanley) Nichols, 1973, p. 107.

Remarks.-Tschudy and Van Loenen (1970, pl. 3, figs. $3-7,21$ ) illustrated a variety of small triatriate grains, all of which are of types that I have included in $M . m i$ crofoveolatus. Jackson grains assigned to this species are small (14-25 $\mu \mathrm{m}$, rarely larger than $22 \mu \mathrm{m})$, and most have straight to concave sides; most grains of Momipites coryloides Wodehouse from the same strata are larger $(20-34 \mu \mathrm{m}$, rarely smaller than $23 \mu \mathrm{m})$ and have convex sides. Momipites microfoveolatus is infragranulate rather than finely pitted as stated by Stanley $(1965$, p. 301). Elsik (1968b, p. 602) also pointed out that Engelhardtiatype pollen grains are "never punctate or foveolate except in degraded specimens."

Affinity.-Engelhardtia group (Juglandaceae).

Occurrence.- "Infrequent" to "abundant" in every sample; generally less abundant in the uppermost part of the Yazoo Clay, Forest Hill Sand, and Red Bluff Clay than lower in the section, and usually less abundant than Momipites coryloides in any given sample.

\section{Genus PLATYCARYA Siebold and Zuccarini}

\section{Platycarya sp.}

Plate 7, figure 17

Triatriopollenites ef. T. coryphaeus (R. Potonié, 1931) Thomson and Pflug, 1953. Engelhardt, 1964a, p. 78, pl. 4, fig. 47.

Platycarya spp. Tschudy, 1973, p. B14, pl. 2, figs. 30-31 only.

Description.-On the basis of four specimens (one of Engelhardt, 1964a, two of Tschudy, 1973, and one of mine), the size is $18-20 \mu \mathrm{m}$. Oblate; outline rounded triangular. Exine between apertures slightly less than 1 $\mu \mathrm{m}$ thick; intectate; nexine very thin. Outer exine surface smooth; design infragranulate, probably owing to the roughness of the exine's inner surface. Each hemisphere crossed by one or two long, curving, narrow (11.5- $\mu \mathrm{m}$-wide) pseudocolpi, which may have upturned edges. Triporate, pores 1-2 $\mu \mathrm{m}$ wide, atrium $3-4 \mu \mathrm{m}$ wide; little or no annulus or tumescence present.

Occurrence.-One probable specimen of this species was observed from the Cockfield Formation at Jackson, Miss. Another specimen from the formation at the same locality was illustrated by Engelhardt (1964a, pl. 4, fig. 47). Elsik (1974b, fig. 3) showed Platycarya as ranging up into the basal strata of the Jackson Group in Texas. The present species ranges down at least into the upper part of the Wilcox Group (Tschudy, 1973, p. B14).

\section{Genus TRIPOROPOLLENITES Pflug and Thomson in Thomson and} Pflug, 1953

Triporopollenites? maternus (Potonié) n. comb.

Plate 7, figures 18-19

Pollenites maternus Potonié, 1931b, p. 4, fig. 19 (basionym).

Pollenites granifer maternus (Potonié) Potonié and Venitz, 1934, p. 23, pl. 2 , fig. 45.

Remarks.-In the gulf coast specimen, the exine is distinctly granulate, there is virtually no splitting apart of the sexine and nexine at the apertures, the endopore is only slightly larger than the ektopore, and the sexine is slightly thickened at the apertures. This species cannot be placed satisfactorily in any existing genus. It is temporarily assigned to Triporopollenites because of its betulacoid morphology. It might be a four-pored variant of a normally three-pored pollen species.

Affinity.-Unknown.

Occurrence.-One specimen observed from the Gosport Sand of Little Stave Creek.

\section{Genus LUDWIGIA Linnaeus}

Ludwigia oculus-noctis (Thiergart) n. comb.

Plate 7, figure 20

Pollenites oculus noctis Thiergart, 1940, p. 47, pl. 7, fig. 1 (basionym). Jussiaea champlainensis Traverse, 1955, p. 66, fig. 12 (104).

Corsinipollenites oculus noctis (Thiergart) Nakoman, 1965, p. 156, pl. 13 , figs. $1-5$.

Remarks.-The hyphen between oculus and noctis was omitted in the papers by Thiergart (1940) and Nakoman (1965), but at least Thiergart intended it to be present (Ames and Kremp, 1964, p. 21-142). Jussiaea L. is a junior synonym of Ludwigia L. (Willis, 1966, p. 594), of the family Onagraceae.

Occurrence. - "Infrequent" in 14/56 counted samples, from the upper part of the Claiborne Group to the lower part of the Vicksburg Group. 
Genus PROTEACIDITES Couper, 1953 emend. Martin and Harris, 1974

Proteacidites? laxus Frederiksen

Plate 7, figures 21-22

Proteacidites? laxus Frederiksen, 1973, p. 72-73, pl. 2, figs. 1-4.

Remarks.-In their redescription and emendation of Proteacidites, Martin and Harris (1974, p. 109) noted that grains of this genus are tegillate, which is not true of $P$.? laxus. This species is characterized by its slightly convex sides, simple pores, and the coarse, loose reticulum to which the name refers.

Affinity.-Perhaps Symplocaceae or Palmae.

Occurrence._- "Infrequent" in 9/56 counted samples from the upper part of the Claiborne Group to the lower part of the Vicksburg Group.

\section{Genus CASUARINIDITES Cookson and Pike, 1954}

Casuarinidites discrepans (Frederiksen) n. comb.

Plate 7, figure 24

Triporopollenites discrepans Frederiksen, 1973, p. 74, pl. 2, figs. 6-8 (basionym).

Remarks. - This species is similar to North American species assigned to Casuarinidites by Srivastava (1972) in having the sexine much thicker than the nexine, and in the fact that short columellae are present below the thick, nearly structureless ectosexine; the columellae become slightly longer in the region of the pore.

Affinity.-Unknown.

Occurrence.-Observed only in the North Twistwood Creek Member of the Yazoo Clay in eastern Mississippi and western Alabama; "infrequent" in two counted samples and also observed in one partially scanned sample.

Casuarinidites cf. C. granilabratus (Stanley) Srivastava

Plate 7, figures 25-27

Corylus granilabrata Stanley, 1965, p. 293, pl. 43, figs. 17-28.

Casuarinidites granilabratus (Stanley) Srivastava, 1972, p. 243-244, pl. 9, figs. 1-12; pl. 10, figs. 1-4.

Remarks.-These specimens are intermediate in morphology between C. granilabratus and C. pulcher (Simpson, 1961) Srivastava, 1972. They are rather thin-walled like $C$. granilabratus, but they have little or no labrum, like $C$. pulcher. It is not clear whether the specimens in my material are reworked from the Paleocene or whether they represent a distinct species produced during late Eocene and early Oligocene time.

Affinity.-Unknown.

Occurrence. - "Infrequent" to "occasional" in 20 or $21 / 56$ counted samples from the upper part of the Claiborne Group through the Jackson Group; not observed in the lower part of the Vicksburg Group.

\section{Genus TRIATRIOPOLLENITES Thomson and Pflug, 1953}

\section{Triatriopollenites? aff. T. aroboratus Pflug}

Plate 8, figures 1-2

Triatriopollenites aroboratus Pflug in Thompson and Pflug, 1953, p. 80, pl. 7, figs. 139-147.

Extratriporopollenites cf. E. fractus Pflug in Thomson and Pflug, 1953. Engelhardt, 1964a, p. 78, pl. 5, fig. 53.

Description.-Size 28-31 $\mu \mathrm{m}$ (three specimens, including Engelhardt's (1964a, pl. 5, fig. 53) illustrated specimen). Tricolporate? Oblate; outline triangular with slightly convex sides and rather pointed corners. Exine densely infragranulate to infrapunctate, surface nearly smooth. Exine about $1.5 \mu \mathrm{m}$ thick along sides; sexine:nexine ratio about 2:1. Sexine structureless to indistinctly tegillate. On two specimens (pl. 8, fig. 1 and Engelhardt's specimen), the sexine thickens gradually toward the apertures (tumescence), but on the third specimen (pl. 8, fig. 2), it thins slightly toward the apertures. Interloculum, $0.5 \mu \mathrm{m}$ wide. Atria very deep, about 4-7 $\mu \mathrm{m}$ deep. Aperture type probably should be considered tricolporate rather than triporate; the aperture structure is like the notch at the feathered end of an arrow. Apertures $0.5-1 \mu \mathrm{m}$ in diameter, widening slightly inward; apertures 1.5-2.5 $\mu \mathrm{m}$ deep.

Remarks.-These three specimens have not been grouped into a new species because the specimens vary in the change of sexine thickness toward the apertures. Triatriopollenites aroboratus Pflug appears to be very similar, but its sexine and nexine are of equal thickness and the interloculum is narrower.

\section{Affinity.-Unknown.}

Occurrence.-Three specimens known, one each from the Gosport Sand and Moodys Branch Formation at Little Stave Creek and the Cockfield Formation in western Mississippi.

\section{Triatriopollenites proprius (Frederiksen) n. comb.}

Plate 7, figure 23

Myrica propria Frederiksen, 1973, p. 73-74, pl. 2, figs. 5, 9-11.

Remarks. - The photomicrograph of the holotype (pl. 7, fig. 23) does not show it well, but the atrium and the tumescence and tarsus pattern of the sexine are distinct in this species, and it is very similar to pollen of modern Myricaceae. According to Wodehouse (1935, p. 373), in pollen of Comptonia "The pores may be equally spaced around the equator of the grain as in those of Myrica, but they are more often irregularly arranged, particularly when there are three when they are generally gathered into one hemisphere." In Triatriopollenites proprius, there is no tendency toward asymmetry of the pores, but asymmetry of pores is not strongly evident in the available slide of modern Comptonia pollen; in other respects, little difference exists among the pollen types 
of modern Myrica, Gale, and Comptonia. Because the Jackson species could represent any of these three genera, it is transferred to Triatriopollenites. An atrium may be present in Myricipites speciosus Manum, 1962. However, in the latter species, the exine thickening at the apertures is annulate rather than tumescent as in Triatriopollenites proprius.

Occurrence.- "Infrequent" to "occasional" in 24/56 counted samples from the upper part of the Claiborne Group to the lower part of the Vicksburg Group.

\section{Genus TRIVESTIBULOPOLLENITES Pflug in Thomson and Pflug,} 1953

Trivestibulopollenites engelhardtii Frederiksen

Plate 8, figure 3

Betulaceoipollenites cf. B. bituitus (R. Potonié, 1931) Potonié, 1951. Engelhardt, 1964a, p. 76, pl. 4, fig. 42.

?Betulaceoipollenites sp. Tschudy and Van Loenen, 1970, pl. 3, fig. 8. Trivestibulopollenites engelhardtii Frederiksen, 1973, p. 74-75, pl. 2, figs. 12-14.

Remarks.-This species has convex sides, a granulate exine, distinct labra, and very shallow vestibula, which however are crossed by indistinct columellae as in $\mathrm{Cas}$ uarinidites. Therefore the species is similar to at least some specimens of Casuarinidites granilabratus (Stanley, 1965) Srivastava, 1972. Whether the two species are conspecific remains to be determined, but $C$. granilabratus is typically atriate, whereas Trivestibulopollenites engelhardtii is vestibulate.

Affinity.-Probably Betula or Ostrya (Betulaceae).

Occurrence.- "Infrequent" in 15/56 counted samples from the upper part of the Claiborne Group to the lower part of the Vicksburg Group.

\section{Genus BETULA Linnaeus \\ Betula? sp. \\ Plate 8, figure 4}

Remarks. - These specimens are very similar to pollen of modern Betula except that the labrum is higher, causing the vestibulum to be very deep. The labrum and vestibulum of this species are similar to those of Trivestibulopollenites salebrosus Pflug in Thomson and Pflug, 1953.

Occurrence.-Two specimens observed in a sample of Red Bluff Clay from eastern Mississippi.

\section{Genus PLICAPOLLIS Pfing, 1953}

Plicapollis spatiosa Frederiksen

Plate 8, figure 5

Plicapollis spatiosa Frederiksen, 1973, p. 75, pl. 2, figs. 15-18.

Remarks._Pflug (1953, p. 97) based his genus Plicapollis largely on the presence of "endoplicae" in the ex- ine. Skarby $(1968$, p. 20$)$ showed that the "endoplicae" are only compression folds, and she placed Plicapollis into synonymy with Extratriporopollenites Pflug. However, the triradiate compression folds in this and most other species of Plicapollis are very even in shape, and every grain of a given species seems to have them; thus, species of this genus are easy to recognize, and keeping Plicapollis as a separate genus appears to be worthwhile. In her emendation of Extratriporopollenites, Skarby $(1968$, p. 25$)$ stated that pollen grains of the latter genus (including Plicapollis) have "intumescence fillings" as an essential feature. A reexamination of $\mathrm{Pli}$ capollis spatiosa shows that an annulus and an endannulus are both present at each aperture, but no "intumescence fillings" can be observed. In this species, the exine stratification between apertures is obscure, and the exine there is 1-1.5 $\mu \mathrm{m}$ thick. At the apertures, the annulus and endannulus are each $1.5-3 \mu \mathrm{m}$ thick. It is characteristic of the species that the nexine bends about $90^{\circ}$ at the aperture and thickens to become an endannulus, forming the base of the diamond-shaped to lenticular vestibulum.

\section{Affinity.-Unknown.}

Occurrence.- "Infrequent" in six counted samples from the lower part of the Yazoo Clay to the lower part of the Vicksburg Group and only in samples from western Mississippi. This species has previously been reported as being present only in the Cretaceous of North America (Tschudy, 1975, pl. 9, figs. 15-24; Williams and Brideaux, 1975, pl. 42, figs. 6, 10, and references to other papers on p. 65-66). Therefore, specimens of the species from the Jackson and lower part of the Vicksburg may be reworked.

\section{Genus THOMSONIPOLLIS Krutzsch, 1960}

Thomsonipollis magnifica (Pflug) Krutzsch

Plate 8, figure 6

Intratriporopollenites magnificus Pflug in Thomson and Pflug, 1953, p. 88, pl. 9, figs. 112-124.

Thomsonipollis magnificus (Pflug) Krutzsch, 1960, p. 55.

Remarks.-The synonymy of this species was discussed by Elsik (1968b, p. 616).

Affinity.-Possibly Rubiaceae (Elsik, 1968b, p. 618).

Occurrence. - "Infrequent" in five counted samples, ranging from the lower part of the Yazoo Clay to the lower part of the Vicksburg Group. This species has previously been reported from the gulf coast only from the Upper Cretaceous, the Midway and Wilcox Groups, and basal part of the Claiborne Group (Tschudy, 1973, fig. 2; Elsik, 1974b, fig. 2). Therefore, the specimens from the Jackson and Vicksburg Groups may be reworked. However, all specimens observed in this material are in perfect condition. 


\section{Genus CARYA Nuttall \\ Carya simplex (Potonié) Elsik \\ Plate 8 , figure 7}

Pollenites simplex Potonié, 1931b, p. 2, fig. 4.

Pollenites globiformis Potonié, 1931b, p. 2, fig. 5.

Hicoria viridi-fluminipites Wodehouse, 1933, p. 503, fig. 29.

Subtriporopollenites simplex simplex (Potonié) Thomson and Pflug, 1953, p. 86, pl. 9, figs. 64-73.

Caryapollenites simplex (Potonié) Potonié, 1960, p. 123, pl. 7, fig. 162.

Carya simplex (Potonié and Venitz 1934) Elsik, 1968a, pl. 2, fig. 1; 1968 b, p. 602, pl. 16, fig. 21-24.

Carya sp. or Caryapollenites sp. Tschudy and Van Loenen, 1970, pl. 3 , fig. 10.

Polyporopollenites sp. (?four-pored Caryapollenites). Tschudy and Van Loenen, 1970, pl. 3, fig. 17.

Carya sp. $(29 \mu-39 \mu)$ Tschudy, 1973, p. B15, pl. 3, figs. 26-27 only.

Occurrence._- "Infrequent" to "common" in $49 / 56$ counted samples from the upper part of the Claiborne Group to the lower part of the Vicksburg Group. The maximum relative frequency is mainly in the lower part of the Vicksburg.

\section{Carya veripites Wilson and Webster}

Plate 8, figure 8

Carya veripites Wilson and Webster, 1946, p. 276, fig. 14

Caryapollenites cf. C. simplex (R. Potonié, 1931) Raatz, 1937. Engelhardt, 1964a, p. 78, pl. 5, fig. 51.

Carya sp. or Caryapollenites sp. cf. C. simplex (Potonié) Raatz 1937. Tschudy and Van Loenen, 1970, pl. 3, fig. 11.

Carya sp. or Caryapollenites sp. Tschudy and Van Loenen, 1970, pl. 3 , figs. $12 \mathrm{a}-\mathrm{b}$.

Carya sp. $(29 \mu-39 \mu)$ Tschudy, 1973, p. B15, pl. 3, fig. 25 only.

Remarks. - Two characters that may be used to differentiate species of Carya pollen grains are the size of the pores and the distance of the pores from the equator. The holotypes of Pollenites simplex Potonié, 1931b, and Pollenites globiformis Potonié, 1931b, may have small pores, whereas the holotype of Carya veripites clearly has rather large ones. However, pore size is very difficult to use consistently as a criterion when one needs to identify every Carya grain to form-species level for the counts. Pore size even varies within individual grains; see, for instance, pl. 3, fig. 17 of Tschudy and Van Loenen (1970), where the upper right pore is distinctly smaller than the two lower ones. Therefore, I have distinguished between Carya veripites and Carya simplex by the fact that the pores in the latter are closer to the outline than the pores in $C$. veripites.

Occurrence. - "Infrequent" to "occasional" in 21/56 counted samples from the upper part of the Claiborne Group to the lower part of the Vicksburg Group. The maximum relative frequency is in the lower part of the Vicksburg.

\section{Genus ALNUS Ehrhart \\ Alnus vera (Potonié) Martin and Rouse \\ Plate 8, figures 9-10}

Pollenites verus Potonié, 1931a, p. 332, pl. 2, fig. 40.

Polyvestibulopollenites verus (Potonié, 1934) Thomson and Pflug, 1953, p. 90 , pl. 10, figs. 62-76.

Alnipollenites verus (Potonié, 1934) Potonié, 1960, p. 129.

Alnipollenites cf. A. verus Potonié, 1934. Engelhardt, 1964a, p. 79, pl. 5 , fig. 57.

Alnus verus (Potonié) Martin and Rouse, 1966, p. 196, pl. 8, figs. 6971.

Alnus sp. or Alnipollenites sp. Tschudy and Van Loenen, 1970, pl. 3, figs. $18,20,26$.

Remarks.-The synonyms of Alnus vera were listed by Martin and Rouse (1966, p. 196) and Srivastava (1972, p. 266).

Occurrence._"Infrequent" to "occasional" in $18 / 56$ counted samples from the upper part of the Claiborne Group to the lower part of the Vicksburg Group.

Genus PLANERA J. F. Gmelin

Planera? thompsoniana Traverse

Plate 8 , figures $11-12$

Planera thompsoniana Traverse, 1955, p. 52, fig. 10 (53).

Ulmus (cf. Zelkova). Gray, 1960, table 1 and fig. 1 .

Ulmipollenites ef. U. undulosus Wolff, 1934. Engelhardt, 1964a, p. 79, pl. 5 , fig. 58.

Ulmipollenites sp. Tschudy and Van Loenen, 1970, pl. 3, figs. 16, 22, 25.

Affinity.-Gray (1960, fig. 1 and table 1) attributed this species to Ulmus or possibly Zelkova, whereas Traverse $(1955$, p. 52) had placed it in Planera. These grains have definite arci, typical of Planera and Zelkova but not of Ulmus. Berry (1924) identified leaves of Planera in the Jackson Group but did not identify any megafossils of Ulmus or Zelkova.

Occurrence. - "Infrequent" to "common" in $45 / 56$ counted samples from the upper part of the Claiborne Group to the lower part of the Vicksburg Group. The maximum relative frequencies are mainly in the upper part of the Yazoo Clay and lower part of the Vicksburg.

\section{Genus MYRIOPHYLLUM Linnaeus}

\section{Myriophyllum sp.}

Plate 8, figures 13-14

Description. - Size $25 \times 28 \mu \mathrm{m}$ (one specimen); oblate? Exine, $2 \mu \mathrm{m}$ thick between pores; nexine, everywhere very thin; exine, psilate with scattered, small foveolae. Tetraporate; sexine, $5 \mu \mathrm{m}$ thick at pores, forming annuli $10 \mu \mathrm{m}$ in diameter; pores, round, $3 \mu \mathrm{m}$ in diameter.

Remarks. - Haloragacidites trioratus Couper, 1953, is triporate but otherwise quite similar. Myriophyllum sp. 
may be conspecific with Myriophyllum ambiguipites Wodehouse, 1933.

Occurrence. - One specimen observed from the upper part of the Yazoo Clay of western Mississippi.

\section{Genus PTEROCARYA Kunth}

\section{Pterocarya stellata (Potonié) Martin and Rouse}

Plate 8, figure 15

Pollenites stellatus Potonié, 1931b, p. 4, fig. 20.

Polyporopollenites stellatus (Potonié) Thomson and Pflug, 1953, p. 91-92, pl. 10, figs. 85-94.

Polyatrio-pollenites stellatus (Potonié) Pflug, 1953, p. 115, pl. 24, fig. 47.

Pterocarya vermontensis Traverse, 1955, p. 45, fig. 9 (29).

Pterocaryapollenites stellatus (Potonié) Potonié, 1960, p. 132.

Pterocaryapollenites vermontensis (Traverse) Potonié, 1960, p. 132.

Pterocarya stellatus (Potonié) Martin and Rouse, 1966, p. 196, pl. 8, figs. 79-80.

Multiporopollenites sp. Tschudy and Van Loenen, 1970, pl. 3, fig. 24.

Occurrence.- -Infrequent" in 12/56 counted samples from the upper part of the Claiborne Group to the lower part of the Vicksburg Group in western and eastern Mississippi.

\section{Genus JUGLANS Linnaeus}

Juglans nigripites Wodehouse

Plate 8, figures $16-17$

Juglans nigripites Wodehouse, 1933, p. 504, fig. 31.

Juglans sp. Fairchild and Elsik, 1969, p. 84, pl. 37, fig. 14.

Multiporopollenites sp. Tschudy and Van Loenen, 1970, pl. 3, fig. 33.

Occurrence. - "Infrequent" in 30/56 counted samples from the upper part of the Claiborne Group to the lower part of the Vicksburg Group.

\section{Genus JUGLANSPOLLENITES Raatz, 1937}

\section{Juglanspollenites infrabaculatus Frederiksen}

Plate 8 , figures $18-19$

Juglanspollenites infrabaculatus Frederiksen, 1973, p. 78-79, pl. 2, figs. 30-33.

Remarks.-Distinguishing features of this species are the presence of 15-20 foramina in combination with the distinct columellae of the sexine.

Affinity.-Unknown.

Occurrence. - "Infrequent" to "occasional" in 28/56 counted samples from the upper part of the Claiborne Group to the lower part of the Vicksburg Group.

\section{Genus CELTIS Linnaeus}

Celtis tschudyi (Elsik) n. comb.

Plate 8, figures 23-25

Pollenites anulus (Potonié, 1931) Potonie and Venitz, 1934 [misidentified]. Engelhardt, 1964a, p. 79, pl. 5, figs. 60-61.
Juglanspollenites sp. Tschudy and Van Loenen, 1970, pl. 3, figs. 2930.

Multiporopollenites spp. Tschudy, 1973, p. B15, pl. 3, figs. 20-22 Nothofagus tschudyi Elsik, 1974a, p. 290, 292-294, pl. 1, figs. 1-5; pl. 2, figs. 1-9 (basionym).

Cf. Nothofagus Dombeyi Type. Elsik, 1974b, p. 2, fig. 44.

Remarks.-The species is characterized by having four to eight pores, more or less equatorially arranged but some of them on a different plane than others; nexine thickens abruptly at the pore, forming an endannulus; the ectosexine and nexine also appear to split apart at the pore, this apparent split is due to a slight thickening of the endosexine there, forming an annulus which is less strongly expressed than the endannulus; pore, circular, or commonly, irregularly shaped, but not usually oval or boat shaped; margin of pore may be rough, uneven; outer surface of exine and pore canal generally meet to form a sharp right angle as seen in optical section, or the sexine overhangs the pore canal; surface of exine nearly smooth, design finely infragranulate to punctate to nearly psilate, exine weakly tegillate; the ratio ectosexine:endosexine:nexine is 1:2:1. Every one of these features is typical of modern Celtis pollen grains. No convincing evidence exists that this species is colpoidate and thus might be Nothofagus. The pollen grains from the London Clay (Eocene) identified as Nothofagus by Sein (1961) were probably misidentified (van Steenis, 1962, p. 280). Apparently, a complete range of specimens exists from the holotype of Celtis tschudyi to the holotype of Celtis texensis Elsik, 1974b; that is, Celtis texensis appears to be an end member of the series of specimens constituting C. tschudyi. However, C. texensis was not clearly enough defined that it can be easily compared with $C$. tschudyi. I have observed only three specimens of $C$. tschudyi in my material; they measure 23,24 , and $29 \mu \mathrm{m}$ in diameter, respectively; all have four pores, two specimens having pores with rough margins; all three specimens are from the upper part of the Cockfield Formation and the Cockfield-Moodys Branch transition interval of western Mississippi.

\section{Genus PARSONSIDITES Couper, 1960}

\section{Parsonsidites conspicuus Frederiksen}

Plate 8 , figures 21-22

Multiporopollenites sp. Tschudy and Van Loenen, 1970, pl. 3, figs. 31-32.

Multiporopollenites sp. of the Dorstenia type. Tschudy, 1973, p. B17, pl. 4 , figs. $29-30$

Parsonsidites conspicuus Frederiksen, 1973, p. 78, pl. 2, figs. 24-27.

Remarks. - This species is distinguished by its wide columellate annuli, which are punctate in design.

Affinity.-Probably not Chenopodiaceae, as suggested earlier (Frederiksen, 1973, p. 78). Similar to 
grains in Apocynaceae (Couper 1960, p. 69), Balanophoraceae (L. M. Cranwell, written commun., 1973), and Dorstenia (Moraceae; Tschudy, 1973, p. B17). However, at least in Dorstenia contrajerva L., true annuli are probably lacking; the rings around the pores appear to be caused by actual detachment of the sexine from the nexine, with the detached sexine forming a hump over the flat nexine on either side of the pore in optical section. No columellae are present in Dorstenia as they are in Parsonsidites conspicuus.

Occurrence.- "Infrequent" in 22 or 23/56 counted samples; it ranges only from the lower part of the Moodys Branch Formation to the lower part of the Vicksburg Group. Tschudy (1973, p. B17) also reported that he did not observe this species below the Jackson Group.

Genus MALVACIPOLLIS Harris, 1965, emend. Krutzsch, 1966

Malvacipollis tschudyi (Frederiksen) n. comb.

Plate 8, figure 27

?Aff. Nothofagus sp. Tschudy and Van Loenen, 1970, pl. 3, figs. 23, 27-28.

Echiperiporites spp. Tschudy, 1973, p. B15, pl. 3, figs. 13-14.

Echiperiporites tschudyi Frederiksen, 1973, p. 75, 78, pl. 2, figs. 1922 (basionym).

Remarks.-Potonie $(1970$, p. 138$)$ reported that the holotype of the type species of Echiperiporites van der Hammen and Wijmstra, 1964, is inaperturate. Malvacipollis tschudyi is characterized by being stephanoporate and by having an exine that is tegillate, granulate, and rather finely conate.

Affinity.-Probably Malvaceae; however, Tschudy (1973, p. B15) noted a similarity to pollen grains of Picrodendraceae.

Occurrence._- "Infrequent" in 10/56 counted samples from the upper part of the Claiborne Group to the lower part of the Vicksburg Group.

\section{Genus ANACOLOSIDITES Cookson and Pike, 1954}

Anacolosidites efflatus (Potonié) Erdtman

Sporites efflatus Potonié, 1934, p. 37-38, pl. 1, figs. 17-18.

Anacolosidites efflatus (Potonié) Erdtman, 1954, p. 804-805.

Affinity.-Olacaceae, probably Anacolosa, Cathedra, or Ptychopetalum (Erdtman, 1954, p. 804).

Occurrence. -This species was observed by Engelhardt (1964a, p. 78, pl. 5, fig. 54) in the Cockfield Formation; I did not find it.

\section{Anacolosidites sp. \\ Plate 8 , figure 20}

Description.-Size $17 \mu \mathrm{m}$ (one specimen); oblate or peroblate; outline triangular with slightly concave sides; six-forate (three-diploforate), pores $2 \mu \mathrm{m}$ in diameter. Exine $1 \mu \mathrm{m}$ thick along sides and slightly thinner at corners; weakly plicate; equatorial area of exine finely reticulate, polar area (inside of plicae) evidently punctate to psilate (polar area on one side is missing).

Remarks.-Anacolosidites sp. is characterized by its reticulate design and small size.

Affinity.-Olacaceae, Anacolosa, or a closely related genus.

Occurrence.-One specimen observed from the Cocoa Sand Member of the Yazoo Clay at Little Stave Creek.

\section{Genus CHENOPODIPOLLIS Krutzsch, 1966}

Chenopodipollis sp.

Plate 8, figure 26

Affinity.-Chenopodiaceae or Amaranthaceae.

Occurrence.-One specimen observed from the Moodys Branch Formation at Little Stave Creek.

\section{Genus LYMINGTONIA Erdtman, 1960 \\ Lymingtonia cf. L. rhetor Erdtman}

Plate 9, figures 1-3

Lymingtonia rhetor Erdtman, 1960, p. 47-48, pl. 2, figs. a-c.

Lymingtonia ef. L. rhetor Erdtman. Elsik and Dilcher, 1974, p. 77, pl. 29 , figs. 123-125.

Remarks. - The size range of my specimens is $25 \mu \mathrm{m}$ ?, $30-45 \mu \mathrm{m}$. Elsik and Dilcher $(1974$, p. 77$)$ gave a size range of 28-32 $\mu \mathrm{m}$ for their specimens of Lymingtonia cf. L. rhetor, from the Claiborne Group of Tennessee, whereas Erdtman (1960, p. 48) reported that his specimens of $L$. rhetor were about $50 \mu \mathrm{m}$.

Affinity.-Probably Nyctaginaceae, similar to Phaeoptilum (Erdtman, 1960, p. 48).

Occurrence.- "Infrequent" in four or five samples from the Gosport Sand (and Cockfield Formation?), Yazoo Clay, and Forest Hill Sand, from western Mississippi to western Alabama.

Genus MONOSULCITES Couper, 1953 emend. Potonié, 1958

\section{Monosulcites asymmetricus Frederiksen \\ Plate 9, figure 4}

Monosulcites asymmetricus Frederiksen, 1973, p. 79, pl. 2, figs. 23, 28-29, 34-35.

Remarks. -Grains included in this species are psilate, are typically asymmetrically oval, and have a boat-shaped sulcus that extends nearly the full length of the grain. Monocolpopollenites tranquilloides Nichols and others (May 1973) is, on average, slightly larger than Monosulcites asymmetricus Frederiksen (April 1973), but otherwise the two species appear to be identical. 
Affinity.-Probably Palmae. This species is very similar to Oligocene pollen labeled Thrinax by Machin (1971, pl. 2, fig. 11); however, modern pollen of Thrinax argentea Desf. is quite different, being distinctly reticulate.

Occurrence.- "Infrequent" to "occasional" in $32 / 56$ counted samples from the upper part of the Claiborne Group to the lower part of the Vicksburg Group.

\section{Genus CONFERTISULCITES Anderson, 1960}

\section{Confertisulcites fusiformis Frederiksen}

Plate 9, figure 11

Monosulcites sp. Tschudy and Van Loenen, 1970, pl. 1, fig. 9.

Confertisulcites fusiformis Frederiksen, 1973, p. 79-80, pl. 3, figs. 6-8.

Remarks. - In this species, the grains are large, fusiform, and psilate and have a long, narrow sulcus.

Affinity.-Possibly Magnoliaceae.

Occurrence.- "Infrequent" in 11 or $12 / 56$ counted samples from the upper part of the Claiborne Group to the top of the Yazoo Clay, and possibly also in the lower part of the Vicksburg Group.

\section{Genus MONOCOLPOPOLLENITES Pflug and Thomson in Thomson} and Pflug, 1953 emend. Nichols and others, 1973

Monocolpopollenites tranquillus (Potonié) Thomson and Pflug

Plate 9, figure 5

Pollenites tranquillus Potonié, 1934, p. 51, pl. 2, figs. 3, 8.

Monocolpopollenites tranquillus (Potonié) Thomson and Pflug, 1953, p. 62-63, pl. 4, figs. 24-37, 39-47.

Palmaepollenites tranquillus (Potonié) Potonié, 1958, p. 97, pl. 11, fig. 138.

Monosulcites sp. Tschudy and Van Loenen, 1970, pl. 1, fig. 15.

Remarks.-The grains assigned to this species from my material are very similar to Potonié's (1934, pl. 2, figs. 3 and 8) original middle Eocene specimens of $\mathrm{Pol}$ lenites tranquillus, as redescribed by Krutzsch (1962, p. 270) and Nichols and others (1973). They are generally asymmetrical, one end being wider than the other; the exine is indistinctly tegillate and the surface is only slightly roughened, the design is weakly granulate, the sulcus usually extends only about three-fourths the length of the grain, and the ends of the sulcus are commonly rounded or flared.

Affinity.-Krutzsch (1970a, p. 27) listed a number of palm genera having pollen grains similar to $M$. tranquillus; these genera now range from North America (Bra$h e a)$ to the Indian Ocean and the southwest Pacific. He pointed out that an affinity of $M$. tranquillus with Phoenix is not probable, because the latter is microreticulate.

Occurrence._- "Infrequent" to "occasional" in 39 to $41 / 56$ counted samples from the upper part of the Claiborne Group to the lower part of the Vicksburg Group.
Genus SABAL Adanson

Sabal cf. S. granopollenites Rouse

Plate 9, figures $6 \_8$

Sabal granopollenites Rouse, 1962, p. 202, pl. 1, figs. 3-4.

Remarks.-These specimens have the same morphology as Sabal granopollenites, that is, they are coarsely to weakly granulate or finely reticulate, tegillate, and have the sulcus extending nearly the full length of the grain, with tapered ends and unthickened margins. The gulf coast specimens are smaller than Rouse's, however. Rouse (1962, p. 202) gave a size range of $28-32 \mu \mathrm{m}$ for $S$. granopollenites, whereas the size range of my specimens is $15-29 \mu \mathrm{m}$, and their mean size is $21 \mu \mathrm{m}$.

Occurrence. - "Infrequent" to "occasional" in 14/56 counted samples from the upper part of the Claiborne Group to the Yazoo Clay.

Genus ARECIPITES Wodehouse, 1933 emend. Nichols and others, 1973

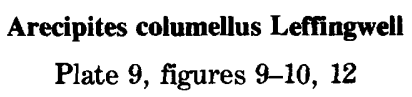

Sabalpollenites ef. S. convexus Thiergart, 1938. Engelhardt, 1964a, p. 71, pl. 2, fig. 14.

Monosulcites sp. Tschudy and Van Loenen, 1970, pl. 1, figs. 10, 14. Arecipites columellus Leffingwell, 1971, p. 40-41, pl. 7, figs. 1-2.

Description.-In my material, the sizes of the specimens of this species are $28-42 \mu \mathrm{m}$; the mean size is 35 $\mu \mathrm{m}$. The outline is oval to asymmetrically elongate, that is, the widest part is offset toward one end; ends are slightly pointed. The length:width ratios are 1.3:1-2.3:1; perhaps the broadly oval forms should be placed in a separate species. Exine slightly more than $1 \mu \mathrm{m}$ thick; ectosexine:endosexine:nexine ratio about $3: 5: 3$, columellae sharply defined. Design of exine distinct and finely reticulate (lumina $0.5 \mu \mathrm{m}$ in diameter or less) to granulate. Sulcus extends full length or nearly full length of grain, usually slightly opened along the whole length, or overlapping, or rarely gaping.

Remarks.-Arecipites punctatus Wodehouse, 1933, is slightly smaller and is less distinctly reticulate than $A$. columellus. In Sabalpollenites convexus Thiergart, 1938, the sulcus widens at each end.

Affinity.-The species is identical with modern pollen of Serenoa serrulata (Michx.) (Palmae).

Occurrence.-_Infrequent" in 14/56 counted samples, from the upper part of the Claiborne Group to the lower part of the Vicksburg Group.

\section{Genus CALAMUSPOLLENITES Elsik in Stover and others, 1966}

Remarks.-I agree with Elsik (in Stover and others, 1966, p. 2; Elsik, 1968a, p. 312; Elsik and Dilcher, 1974, 
p. 74) that the tiny pits in the exine of Calamuspollenites are alined in short rows. Therefore, there is some justification for not merging this genus with Arecipites as was done by Nichols and others (1973, p. 248-250).

Calamuspollenites eocenicus Elsik and Dilcher

Plate 9, figure 13

Calamuspollenites eocenicus Elsik and Dilcher, 1974, p. 74, pl. 28, figs. $66-67$.

Affinity.-Probably Palmae.

Occurrence.- "Infrequent" to "occasional" in three or four samples from the Gosport Sand and the Yazoo Clay. Originally described specimens were from the Claiborne Group of Tennessee.

\section{Genus LILIACIDITES Couper, 1953}

\section{Liliacidites tritus Frederiksen}

Plate 9, figures 14-15

Liliacidites variegatus Couper, 1953 [misidentified]. Engelhardt, 1964a, p. 71 , pl. 2, fig. 13 .

Liliacidites sp. Tschudy and Van Loenen, 1970, pl. 1, fig. 16.

Liliacidites tritus Frederiksen, 1973, p. 80-81, pl. 3, figs. 13-16.

Remarks.-It is characteristic of this species that the lumina are the same size on the distal side as they are on the proximal side; only the one or two rows of lumina along the sulcus may be somewhat smaller than the rest. Liliacidites tritus is similar to Arecipites pseudoconvexus Krutzsch, 1970a, except that the latter has only scattered columellae and has slightly larger lumina. Arecipites wiesaensis Krutzsch, 1970a, has very narrow $(0.25-\mu \mathrm{m}$-wide) muri. Contrary to my earlier opinion (Frederiksen, 1973, p. 80), Monosulcites sp. of Tschudy and Van Loenen (1970, pl. 1, figs. 10, 14) does not belong to Liliacidites tritus but rather to Arecipites columellus Leffingwell, 1971.

Affinity.-Very similar to modern pollen of Pseudophoenix sp.

Occurrence.- "Infrequent" to "common" in 50/56 counted samples from the upper part of the Claiborne Group to the lower part of the Vicksburg Group.

\section{Liliacidites vittatus Frederiksen}

Plate 9, figures 16-17

Liliacidites sp. Tschudy and Van Loenen, 1970, pl. 1, figs. 17-18. Liliacidites vittatus Frederiksen, 1973, p. 80, pl. 3, figs. 1-5. Liliacidites yeguaensis Elsik, 1974b, p. 93, pl. 1, figs. 14-15.

Remarks.-Liliacidites vittatus appears to be identical in all respects with Arecipites lusaticus Krutzsch, $1970 \mathrm{a}$, except that in $L$. vittatus the muri are $1 \mu \mathrm{m}$ wide, whereas in A. lusaticus they are "zart" (slender, delicate; Krutzsch, 1970a, p. 102), only $0.5 \mu \mathrm{m}$ wide.

Affinity. - I suggested previously (Frederiksen, 1973, p. 80) that Liliacidites vittatus might have been pro- duced by Myristica (Myristicaceae). However, a reexamination of modern pollen of Myristica showed that the grains in this genus are quite different. Furthermore, pollen grains of Myristicaceae are too fragile to survive diagenesis (Muller, 1970, p. 419).

Occurrence._-"Infrequent" to "occasional" in 22/56 counted samples from the upper part of the Claiborne Group to the lower part of the Vicksburg Group. Also reported by Elsik (1974b, p. 93) to be present in the upper part of the Claiborne and Jackson Groups of Texas.

\section{Genus NYPA van Wurnib}

Remarks.-Tralau (1964, p. 10) and Muller (1968, p. 11) have pointed out that Nypa is the only extant genus that has spinate zonisulcate pollen grains. Therefore, I consider Spinizonocolpites Muller to be a synonym of Nypa van Wurmb.

\section{Nypa echinata (Muller) n. conb. \\ Plate 9, figures 18-21}

Spinizonocolpites echinatus Muller, 1968, p. 11-12, pl. 3, fig. 3 (basionym).

Nymphaeaceae (see Monocolpopollenites nupharoides Kedves 1960). Tschudy and Van Loenen, 1970, pl. 2, figs. 1, 2a-b.

Affinity.-According to Muller (1968, p. 12), "This pollen species is identical in all respects with the pollen of the Recent Nypa fruticans."

Occurrence.- "Infrequent" in seven counted samples from the lower to the upper parts of the Yazoo Clay and from western Mississippi to western Alabama; also present in an uncounted sample from the base of the Gosport Sand at Little Stave Creek. See figure 4 and the discussion of the range of this species in the section Distribution of the Sporomorphs. Berry (1924, p. 150) recorded Nipadites fruits from the Jackson Group of Texas.

Genus DICOLPOPOLLIS Pflanzl, 1956 eniend. Potonié, 1966

\section{Dicolpopollis sp.}

Plate 9, figure 22

Description.-One specimen found, $27 \times 34 \mu \mathrm{m}$ in size (subprolate). Dicolpate, colpi $25 \mu \mathrm{m}$ long, slightly open, margins not thickened. Exine psilate, $2 \mu \mathrm{m}$ thick, sexine:nexine ratio $3: 1$.

Remarks.-Dicolpopollis simonii Pflanzl, 1956, is prolate to perprolate, has pointed poles, and is granulate.

Affinity.-Unknown.

Occurrence.-One specimen found from the Gosport Sand at Little Stave Creek.

\section{Genus CUPULIFEROIDAEPOLLENITES Potonié, 1960}

Cupuliferoidaepollenites liblarensis (Thomson) Potonié

Plate 9, figure 23

Pollenites liblarensis Thomson in Potonié and others, 1950, p. 55, pl. B, figs. 26-27. 
Tricolpopollenites liblarensis (Thomson) Thomson and Pflug, 1953, p. 96, pl. 11, figs. 111-132.

Cupuliferoidaepollenites liblarensis (Thomson) Potonié, 1960, p. 92, pl. 6, fig. 94.

Tricolpopollenites liblarensis (Thoms.) Th. and Pf., 1953. Tschudy, 1973 , p. B18, pl. 4, figs. 31-33.

Remarks.-A specimen similar to $C$. liblarensis is shown on plate 9 , figure 24 .

Affinity.-Probably Fagaceae (Potonié and others, 1951, p. 55); possibly Leguminosae in part (Thiergart, 1940, pl. 6, fig. 15).

Occurrence.-Present in every sample, mostly "occasional" to "common."

Cupuliferoidaepollenites cf. C. selectus (Potonié) n. comb.

Plate 9, figures 25-27

Pollenites selectus Potonié, 1934, p. 95, pl. 5, fig. 33 (basionym). Tricolpopollenites sp. Tschudy and Van Loenen, 1970, pl. 4, fig. 7.

Description.—Size 17-28 $\mu \mathrm{m}$, mean $23 \mu \mathrm{m}$. Subprolate to prolate. Tricolpate. "Lolongate ora" formed by presence of slits along floors of colpi. Exine about $1 \mu \mathrm{m}$ thick, psilate to weakly punctate.

Remarks:-Cupuliferoidaepollenites selectus has diamond-shaped widenings of the colpi at the equator, with a suggestion of weakly developed lalongate ora as well. Thiergart (in Potonié and others, 1951, pl. C, fig. 21) considered specimens having a slit in the floor of the colpus to belong to the same species as normally tricolpate specimens. I counted $C$. cf. $C$. selectus separately from C. liblarensis (Thomson) Thomson and Pflug to determine whether it has any stratigraphic value; it does not seem to have any within the interval studied here.

Affinity.-Possibly Fagaceae.

Occurrence._- Infrequent" to "common" in 25/56 counted samples from the upper part of the Claiborne Group to the lower part of the Vicksburg Group.

\section{Genus CASSIA Linnaeus}

Cassia certa (Frederiksen) n. comb.

Plate 9, figures 28-29

Cupuliferoidaepollenites certus Frederiksen, 1973, p. 81, pl. 3, figs. 9-12 (basionym).

Remarks. - Characteristics of this species are the rather small size $(15-25 \mu \mathrm{m})$, the psilate exine, and the long, geniculate colpi.

Affinity.-Very similar to pollen of several species of Cassia (Leguminosae).

Occurrence.—"Infrequent" to "occasional" in $19 / 56$ counted samples from the upper part of the Claiborne Group to the lower part of the Vicksburg Group.

\section{Genus FOVEOTRICOLPITES Pierce, 1961}

Foveotricolpites prolatus Frederiksen

Plate 10, figures 1-2

Foveotricolpites prolatus Frederiksen, 1973, p. 81, 84, pl. 3, figs. 1722.

Remarks.-This species is characterized by its prolate shape, distinct tegillum, and long colpi that lack thickened margines.

Affinity. - Similar to modern pollen of Spartium junceum L. (Leguminosae) illustrated by Planchais (1964, pl. 1, figs. 1-7).

Occurrence.- "Infrequent" in 17/56 counted samples from the upper part of the Claiborne Group to the lower part of the Vicksburg Group.

\section{Genus QUERCOIDITES Potonié, 1960}

Quercoidites inamoenus (Takahashi) n. comb.

Plate 10 , figures $3-8$

Tricolpopollenites inamoenus Takahashi, 1961, p. 313, pl. 22, figs. 42 49 (basionym).

Quercoidites cf. Q. henrici (R. Potonié, 1931) Potonié, Thomson, and

Thiergart, 1950. Engelhardt, 1964a, p. 71, pl. 2, fig. 15.

Quercus sp. Fairchild and Elsik, 1969, p. 84, pl. 37, fig. 22.

Tricolpopollenites sp. Tschudy and Van Loenen, 1970, pl. 4, fig. 2.

Quercus sp. Elsik, 1974b, pl. 4, fig. 116.

Remarks.-This species has a variable aperture structure:

1. Simple colpi are most common (pl. 10, figs. 3-4).

2. Geniculi may be present (pl. 10, figs. 5-6).

3. Ora may be present in the form of slits in the floor of the colpi (pl. 10, figs. 7-8).

4. Both slits and geniculi may be present.

Quercoidites inamoenus differs from Q. microhenricii (Potonié) Potonié in being coarsely granulate to verrucate and in having a rougher surface of the exine in optical section. Q. inamoenus is transferred to Quercoidites because the type species of Tricolpopollenites, T. parmularius (Potonié, 1934) Thomson and Pflug, 1953, is psilate.

Affinity.-Quercus or the extinct Dryophyllum (Fagaceae).

Occurrence.-Generally "infrequent" to "occasional" in zone I; "abundant" to "very abundant" in most samples of zone II.

\section{Quercoidites microhenricii (Potonié) Potonié}

Plate 10, figures 9-10

Pollenites microhenrici Potonié, 1931d, p. 26, pl. 1, fig. V19c.

Pollenites henrici microhenrici (Potonié) Potonié and Venitz, 1934, p. 27.

Tricolpopollenites microhenrici (Potonié) Thomson and Pflug, 1953, p. 96 , pl. 11, figs. 62-110.

Quercoidites microhenrici (Potonié) Potonié, 1960, p. 93. 
Remarks._Pflug (in Thomson and Pflug, 1953, p. 96) named two new subspecies of this species, calling them Tricolpopollenites microhenricii intragranulatus and $T$. microhenricii intrabaculatus. The specimen illustrated as plate 2, figure 61, in Potonie and Venitz (1934) is the type specimen of Quercoidites microhenricii according to Potonié (1960, p. 93). This specimen appears to be infragranulate, without distinct columellae. Therefore, Tricolpopollenites microhenricii intragranulatus Pflug (in Thomson and Pflug, 1953, p. 96, pl. 11, figs. 80-110), which lacks distinct columellae, is a synonym of Quercoidites microhenricii microhenricii. The second subspecies, Tricolpopollenites microhenricii intrabaculatus Pflug (in Thomson and Pflug, 1953, p. 96, pl. 11, figs. 62-79) becomes Quercoidites microhenricii intrabaculatus (Pflug) n. comb. Many specimens of $Q$. microhenricii can be assigned easily to one subspecies or the other; on the other hand, the subspecies intergrade, and counting them separately was not practical.

Some specimens of Quercoidites microhenricii are pseudo-orate, that is, they have a slit or ragged tear in the floor of each colpus and thus the colpus looks orate in side view. Such phenomena are common in modern Quercus grains.

Affinity.-Probably Fagaceae, Quercus, or a closely related genus (Thomson and Pflug, 1953, p. 96).

Occurrence.- "Infrequent" to "abundant" in every sample.

\section{Genus FRAXINOIPOLLENITES Potonié, 1960}

Fraximoipollenites medius Frederiksen

Plate 10, figures 11-12

Fraxinoipollenites medius Frederiksen, 1973, p. 84, pl. 3, figs. 2327.

Remarks. -This species includes grains of medium size $(30-44 \mu \mathrm{m})$ that are generally prolate and finely reticlavate.

Affinity.-Unknown, probably not Fraxinus (Oleaceae).

Occurrence. - "Infrequent" to "occasional" in 20/56 counted samples from the upper part of the Claiborne Group to the lower part of the Vicksburg Group.

Fraxinoipollenites cf. F. scoticus (Simpson) n. comb.

Plate 10, figure 18

Menispermum scoticum Simpson, 1961, p. 453, pl. 17, figs. 1-4 (basionym).

Remarks. - Specimens of this species in my material are $25-37 \mu \mathrm{m}$ in length and have broadly rounded poles and long, narrow, deep colpi. The grains are prolate, whereas Simpson's specimens of Menispermum scoticum are subprolate.
Affinity.-Simpson (1961, p. 453) compared his specimens of Menispermum scoticum with $M$. dauricum De Candolle (Menispermaceae), but the morphology of this species probably is not distinctive enough for it to be assigned with confidence to only one modern genus.

Occurrence.- "Infrequent" to "common" in 24/56 counted samples from the upper part of the Claiborne Group to the lower part of the Vicksburg Group.

\section{Fraxinoipollemites variabilis Stamiey}

Plate 10, figure 13

Fraxinoipollenites variabilis Stanley, 1965, p. 306, pl. 45, figs. $29-35$.

Remarks. -Stanley's specimens varied from prolate spheroidal to prolate. Most of my specimens are prolate, a few are subprolate. The grains of Tricolpopollenites haraldii Manum, 1962, are prolate but larger.

Affinity.-Probably not Fraxinus (Oleaceae).

Occurrence. - "Infrequent" to "common" in 48/56 counted samples from the upper part of the Claiborne Group to the lower part of the Vicksburg Group.

\section{Fraxinoipollenites spp.}

Plate 10, figures 14-17

BT-68, ??Rubiaceae?? Traverse, 1955, p. 75, fig. 13 (138).

Tricolpites sp. 3. Engelhardt, 1964a, p. 72, pl. 2, fig. 19.

Tricolpopollenites sp. Tschudy and Van Loenen, 1970, pl. 4, figs. 9, 14.

Description.-About 25-45 $\mu \mathrm{m}$ long; prolate; tricolpate, colpi extend nearly full length of grain; reticulate, the muri clavate in optical section, with lumina $0.5-1$ $\mu \mathrm{m}$ in diameter.

Remarks.-At least two and perhaps three or more species fitting this description were found in my material. These forms were difficult to separate consistently, and they were counted together. Although the specimens are fairly common, they still cannot be split into satisfactory species. Tricolpopollenites reticulatus Takahashi, 1961, Tricolpopollenites vegetus (Potonié, 1934) Krutzsch, 1959a, and Hamamelis scotica Simpson, 1961, all have smaller length:width ratios.

Affinity.-Probably produced by plants of several families.

Occurrence._-"Infrequent" to "common" in $39 / 56$ counted samples from the upper part of the Claiborne Group to the lower part of the Vicksburg Group.

\section{Genus PLATANUS Linnaeus \\ Platanus occidentaloides n. sp. \\ Plate 10, figure 19}

Tricolpites sp. 2. Engelhardt, 1964a, p. 72, pl. 2, fig. 18.

Tricolpopollenites sp. Tschudy and Van Loenen, 1970, pl. 4, figs. 3-6, 10, ?12.

Tricolpites n. sp. A (microreticulate) Tschudy, 1973, p. B13, pl. 2, figs. 11-12 only. 
Description.-Polar axis 26-35 $\mu \mathrm{m}$, equatorial axis (in polar view) $22-35 \mu \mathrm{m}$, holotype $31 \mu \mathrm{m}$. Tricolpate. Spheroidal to subprolate; broadly rounded at the poles. Exine 1.25-1.5 $\mu \mathrm{m}$ thick including reticulum; "nexine":"endosexine":"ectosexine" ratio about $1: 1.5: 1$. Lumina a little less than $0.5 \mu \mathrm{m}$ in diameter. Colpi extend 2/3-3/4 length of grain and are moderately deeply incised; colpi appear narrow in equatorial view but gape widely in polar view; edges of colpi very rough and sometimes beaded; margines thickened little if any.

Holotype.-Plate 10, figure 19, slide $10558 \mathrm{~A}-1$, coordinates $23.3 \times 122.6$, Gosport Sand at Little Stave Creek, Clarke County, Ala.

Remarks.-Distinctive features of this species are the moderately large size, the spheroidal to subprolate shape, the fine reticulum, and, above all, the ragged to beaded edges of the colpi. Tetracolpate specimens of this species are fairly common. Grains of Platanus mullensis Simpson, 1961, are prolate or nearly so, and it is not clear whether the edges of the colpi are ragged. In Platanus scotica Simpson, 1961, the grains are also prolate, and they are so poorly preserved that little can be determined about the exine characteristics.

Affinity.-Very similar to Platanus occidentalis L. except that the fossils are slightly larger and the colpi are slightly deeper than in the modern grains.

Occurrence. - "Infrequent" to "occasional" in 37/56 counted samples from the upper part of the Claiborne Group to the lower part of the Vicksburg Group. Apparently Platanus does not range below the uppermost part of the Claiborne on the gulf coast (Tschudy, 1973, fig. 2, upper part of range line for Tricolpites n. sp. A (microreticulate)).

\section{Genus SALIXIPOLLENITES Srivastava, 1966}

\section{Salixipollenites parvus n. sp.}

Plate 10, figures 20-27

Description.-Size 15-24 $\mu \mathrm{m}$, mean $20 \mu \mathrm{m}$, holotype $16 \mu \mathrm{m}$. Tricolpate. Subprolate to prolate; broadly rounded at the poles. Exine about $1 \mu \mathrm{m}$ thick including ornamentation. Reticulum medium coarse in relation to small size of grain-lumina are $0.5-1 \mu \mathrm{m}$ in diameter. Muri slightly less than $1 \mu \mathrm{m}$ high and about $0.5 \mu \mathrm{m}$ wide, clavate in optical section and distinctly simplibaculate in design. Colpi extend 2/3-3/4 length of grain, inner edges of colpi appearing thickened.

Holotype.-Plate 10, figures 24-25, slide 10657 A-1, coordinates $31.0 \times 110.9$, North Twistwood Creek Member of the Yazoo Clay near Rose Hill, Jasper County, Miss.

Remarks. Salixipollenites parvus is distinguished by its small size (parvus, Latin for "small") and relatively coarse reticulum. Tricolpopollenites retiformis Pflug and Thomson in Thomson and Pflug, 1953, is more finely reticulate. Salixipollenites discoloripites (Wodehouse, 1933) Srivastava, 1966, and S. trochuensis Srivastava, 1966, are more spheroidal than $S$. parvus.

Affinity.-Very similar to modern grains of Olea (Oleaceae). In modern Fraxinus (Oleaceae), the grains are usually larger; in Salix (Salicaceae), they are more prolate and are not flat-ended; and in Sambucus (Caprifoliaceae), they are also more prolate.

Occurrence._-"Infrequent" to "common" in $45 / 56$ counted samples from the upper part of the Claiborne Group to the lower part of the Vicksburg Group.

\section{Genus FRAXINUS Linnaeus \\ Fraxinus? pielii n. sp. \\ Plate 10, figures 28-32}

Description.-Size 24-33 $\mu \mathrm{m}$ (five specimens), mean $28 \mu \mathrm{m}$, holotype $23 \times 26 \mu \mathrm{m}$. Oblate; outline square, with sides slightly to moderately convex. Tetracolpate, colpi $1.5-3 \mu \mathrm{m}$ deep, margines lacking. Exine $1 \mu \mathrm{m}$ thick; tegillate; ectosexine:endosexine:nexine ratio about $1: 1: 1$; finely infrareticulate to finely infragranulate, the lumina or grana $0.3-0.5 \mu \mathrm{m}$ in diameter.

Holotype.-Plate 10, figures 28-29, slide $10553 \mathrm{~A}-$ 1, coordinates $33.2 \times 111.3$, Moodys Branch Formation at Little Stave Creek, Clarke County, Ala.

Remarks.-Fraxinus columbiana Piel, 1971, is otherwise identical, but its colpi are two to three times deeper than colpi in Fraxinus? pielii. Retitetracolpites brevicolpatus Mathur, 1966, has a much thicker exine.

Affinity. - As Piel (1971, p. 1915) pointed out, modern Fraxinus pollen has a coarser reticulum than Fraxinus columbiana Piel or $F$.? pielii.

Occurrence. - "Infrequent" in three counted and two uncounted samples from the upper part of the Claiborne Group to the lower part of the Vicksburg Group.

\section{Genus ROUSEA Srivastava, 1969}

\section{Rousea araneosa (Frederiksen) n. comb.}

Plate 10, figures $33-34$

Albertipollenites? araneosus Frederiksen, 1973, p. 84, pl. 3, figs. 3034 (basionym).

Remarks. - This species is characterized by the rather large lumina and narrow muri of the reticulum and the broadly rounded ends of the colpi in most specimens. The one to two rows of lumina on either side of the colpus are only half as large as the rest of the lumina; therefore the species has been transferred to Rousea.

Affinity.-Probably Bignoniaceae; the rounded ends of the colpi in Rousea araneosa are typical of reticulate, tricolpate grains in this family.

Occurrence.- "Infrequent" to "occasional" in 21/56 counted samples from the upper part of the Claiborne Group to the lower part of the Vicksburg Group. 
Rousea monilifera n. sp.

Plate 10, figures 35-37; plate 11, figures 1-3

Tricolpopollenites sp. Tschudy and Van Loenen, 1970, pl. 4, figs. 20a-b.

Description.-Size $36-45 \mu \mathrm{m}$, mean $40 \mu \mathrm{m}$, holotype $41 \mu \mathrm{m}$. Tricolpate. Subprolate to prolate, rarely spheroidal; broadly rounded at the poles. Exine $0.5-1 \mu \mathrm{m}$ thick excluding ornamentation. Coarsely reticulate; muri 2-3 $\mu \mathrm{m}$ high, clavate in optical section, heads of clavae rounded or more often radially elongate; muri $0.5-0.8$ $\mu \mathrm{m}$ wide and coarsely beaded in design (simplibaculate), the beads $0.7-1 \mu \mathrm{m}$ in diameter, that is, of greater diameter than the width of the muri. Muri may be somewhat discontinuous. Lumina about $2-3 \mu \mathrm{m}$ in diameter, except those near the colpi, which are only about $1 \mu \mathrm{m}$; lumina polygonal to rectangular. Colpi deeply invaginated, extending nearly full length of grain, $0.5-2 \mu \mathrm{m}$ wide, with edges not thickened.

Holotype.-Plate 10, figure 35, slide $10642 \mathrm{~A}-2$, coordinates $20.0 \times 117.8$, Moodys Branch Formation at Jackson, Miss.

Remarks.-Rousea monilifera is characterized by its coarse reticulum and coarsely beaded muri (monile, Latin for "a string of beads").

Affinity. - Very similar to Armeria (Plumbaginaceae); also similar to Amanoa (Euphorbiaceae) according to Elsik and Dilcher (1974, p. 76, pl. 30, figs. 164-165).

Occurrence._- Infrequent" in 10/56 counted samples from the Moodys Branch Formation to the lower part of the Vicksburg Group.

\section{Genus ACER Linnaeus}

Acer? striatellum (Takahashi) n. comb.

Plate 11, figures $4-5$

Tricolpopollenites striatellus Takahashi, 1961, p. 319 , pl. 23 , figs. 50 51 (basionym).

Remarks. - This species is distinctly tegillate, the columellae appearing finely clavate in optical section; the design is finely striate, the lirae varying from finely reticulate to infragranulate to smooth. No geniculi are present, and most grains are prolate, in contrast to Striatopollis terasmaei (Rouse, 1962) n. comb., where the colpi are distinctly geniculate and the shape is variable.

Occurrence._"Infrequent" to "occasional" in 16/56 counted samples from the upper part of the Claiborne Group to the lower part of the Vicksburg Group.

Genus STRIATOPOLLIS Krutzsch, 1959b

Striatopollis terasnaei (Rouse) n. conb.

Plate 11, figure 6

Striopollenites terasmaei Rouse, 1962, p. 212, pl. 4, figs. 30, 35 (basionym).
Remarks. - In this species, the lirae range from smooth to infragranulate to finely reticulate, and the shape varies from prolate to spheroidal. The colpi are geniculate, or else very weakly expressed ora are present. Potonié (1966) placed Striopollenites Rouse, 1962, into synonymy with Striatopollis.

Affinity.-Possibly Acer (Aceraceae), Prunus (Rosaceae), or Anacardiaceae.

Occurrence._- "Infrequent" to "occasional" in $27 / 56$ counted samples from the upper part of the Claiborne Group to the lower part of the Vicksburg Group.

\section{Genus POLYCOLPITES Couper, 1953}

\section{Polycolpites sp.}

Plate 11, figures $7-8$

Description.-Size $40-42 \mu \mathrm{m}$ (two specimens). Oblate. Hexacolpate (possibly colporate, with the ora obscure in polar view), colpi 5-9 $\mu \mathrm{m}$ deep, bordered by conspicuous thickenings that wrap around ends of colpi, thickenings $3.5-4 \mu \mathrm{m}$ wide and $2 \mu \mathrm{m}$ thick. Exine 1$1.5 \mu \mathrm{m}$ thick, punctate to coarsely granulate to verrucate.

Remarks.-Polycolpites viesenensis Krutzsch, 1961, has shallower colpi and is psilate. In Krutzsch's (1961, p. 324) opinion, all oblate, "polycolpate" forms are probably really polycolporate, including the type species of $\mathrm{Po}_{\mathrm{O}}$ lycolpites.

Affinity. -Unknown; somewhat similar grains occur in the Bruniaceae, Linaceae, and Pedaliaceae (Erdtman, 1952, figs. 38B, 143A, 183A) and in the Escalloniaceae (Cranwell, 1953, pl. 1, fig. 19).

Occurrence. - Two specimens observed from the lower part of the Yazoo Clay of western Mississippi.

\section{Genus CUPULIFEROIPOLLENITES Potonié, 1960}

\section{Cupuliferoipollenites spp.}

Plate 11. ficures 9-11

Cupuliferoipollenites cf. C. insleyanus (Traverse, 1955) R. Potonié, 1960. Engelhardt, 1964a, p. 72-73, pl. 2, fig. 23.

Castanea sp. Fairchild and Elsik, 1969, p. 83, pl. 37, fig. 6 .

Remarks.-Specimens included here are oval to straight sided in outline and range from 10 to $23 \mu \mathrm{m}$ in size.

Affinity.-Mainly Dryophyllum (an extinct genus of Fagaceae; Frederiksen, unpub. data, 1977); perhaps few of these grains were produced by Castanea and (or) Castanopsis.

Occurrence._-Occasional" to "very abundant" in every sample. 


\section{Genus CHRYSOPHYLLUM Linnaeus}

Chrysophyllum brevisulcatum (Frederiksen) n. comb.

Plate 11, figure 12

Cupuliferoipollenites brevisulcatus Frederiksen, 1973, p. 85, pl. 3, figs. 28-29 (basionym).

Remarks. -Distinctive features of this species are the small size $(14-21 \mu \mathrm{m})$, the prolate shape with straight sides and broadly rounded poles, the short colpi with lalongate ora, and the dark, thickened, circumequatorial band of exine.

Affinity.-A resemblance of this species to the Umbelliferae was noted in the original description (Frederiksen, 1973, p. 85). However, it now seems clear that the species belongs to Chrysophyllum (Sapotaceae); see for instance, Graham and Jarzen, 1969, fig. 27.

Occurrence.- "Infrequent" to "occasional" in 14/56 counted samples from the upper part of the Claiborne Group to the top of the Yazoo Clay.

\section{Genus CYRILlACEAEPOLLENITES Potonié, 1960}

Cyrillaceaepollemites kedvesii n. sp.

Plate 11, figures 13-18

Description. - Length of polar axis 18-28 $\mu \mathrm{m}$, mean $24 \mu \mathrm{m}$, holotype $25 \mu \mathrm{m}$. Spheroidal or nearly so. Tricolporate; colpi geniculate, narrow, extending nearly full length of grain, with thickened margines $0.5-1 \mu \mathrm{m}$ wide; ora lalongate, $1-2 \mu \mathrm{m}$ wide and as long as $6 \mu \mathrm{m}$. Exine $1 \mu \mathrm{m}$ thick; ectosexine:endosexine:nexine ratio 1:1.5:1, but columellae are not visible or are only faintly visible; design punctate to nearly psilate.

Holotype. -Plate 11, figures 13-14, slide 10696 A-1, coordinates $35.0 \times 124.6$, Moodys Branch Formation at Barnett, Clarke County, Miss.

Remarks. - The geniculus and lack of distinct columellae distinguish this species from subprolate to spheroidal species like Tricolporopollenites labatlanii Kedves, 1969, and Siltaria pacata (Pflug in Thomson and Pflug, 1953) $\mathrm{n}$. comb. The grains are larger on the average, the geniculi are less sharply bent, and the ora are less slitlike than in previously described species of Cyrillaceaepollenites and in modern pollen grains of Cyrillaceae.

Affinity.-Unknown.

Occurrence. - "Infrequent" to "occasional" in $36 / 56$ counted samples from the upper part of the Claiborne Group to the lower part of the Vicksburg Group.

\section{Cyrillaceaepollenites megaexactus (Potonié) Potonié}

Plate 11, figures 19-22

Pollenites megaexactus Potonié, 1931d, p. 26, pl. 1, fig. V42b.

Pollenites cingulum bruehlensis Thomson in Potonié and others, 1950, p. 56, pl. B, figs. 31-33.

Tricolporopollenites megaexactus bruehlensis (Thomson) Thomson and Pflug, 1953, p. 101, pl. 12, figs. 50-57.
Cyrillaceaepollenites megaexactus (Potonié) Potonié, 1960, p. 102. Cyrillaceaepollenites cf. C. megaexactus. Tschudy, 1973, p. B17, pl. 4, figs. 14-17.

Remarks. - The aperture structure is variable from grain to grain, as in modern pollen of Cyrillaceae; the ora vary from distinct and lalongate to very indistinct, expressed only as a diamond-shaped widening of the colpi. My specimens have a polar axis of $14-22 \mu \mathrm{m}$, are almost invariably psilate, and are typically oblate to spheroidal.

Affinity.-Cyrillaceae, Cyrilla and (or) Cliftonia.

Occurrence. - "Infrequent" to "common" in $49 / 56$ counted samples from the upper part of the Claiborne Group to the lower part of the Vicksburg Group.

Cyrillaceaepollenites? ventosus (Potonié) n. comb.

Plate 11, figures 23-24

Pollenites ventosus Potonié, 1931c, p. 556, fig. 15 (basionym).

Pollenites ventosus Potonié. Engelhardt, 1964a, p. 79, pl. 5, fig. 59.

Pollenites pseudolaesius* Potonié, 1931[b]. Fairchild and Elsik, 1969, p. 84, pl. 37, fig. 23 .

Tricolporites sp. (cf. Pollenites ventosus Potonié 1934). Tschudy and Van Loenen, 1970, pl. 4, fig. 30.

Tricolporites sp. Tschudy and Van Loenen, 1970, pl. 4, figs. 31-32.

Cyrillaceaepollenites of the Pollenites ventosus type. Tschudy, 1973, p. B17, pl. 4, figs. $20,21$.

Pollenites laesius type. Elsik, 1974b, pl. 4, fig. 115.

Description.-Grains of this species found in the Jackson Group and adjacent strata may be described as follows. Size 16-22 $\mu \mathrm{m}$, mëan $19 \mu \mathrm{m}$. Oblate. Probably tricolporate, but the ora are obscure. Colpi extend 1/3-2/3 (generally about $1 / 2$ ) the distance to the poles. Exine $0.5-0.8 \mu \mathrm{m}$ thick, sexine:nexine ratio $3: 1$, integillate to indistinctly tegillate, weakly punctate to coarsely granulate; outer and inner surface smooth or rough. Most specimens have a compression fold that forms a dark, circular to rounded triangular ring cut by the tips of the colpi.

Remarks.-Tschudy (1973, p. B17) pointed out that gulf coast pollen grains of this type have been assigned to both Pollenites ventosus Potonie and Pollenites pseudolaesus Potonié. From Potonié's papers (Potonié, 1931b, p. 4; 1931c, p. 556; 1934, p. 77-78; Potonié and Venitz, 1934, p. 37), it appears that Pollenites ventosus is small $(13-20 \mu \mathrm{m})$, has a thin exine (no thicker than $0.5 \mu \mathrm{m}$ ), and is psilate to weakly punctate. Pollenites pseudolaesus is larger $(20-31 \mu \mathrm{m}$, mainly about $30 \mu \mathrm{m})$, has a thicker exine (about $1.5 \mu \mathrm{m}$ ), and is punctate to granulate, mainly granulate. It seems best to leave these as two separate species, distinguished on the basis of overall size and exine thickness. Cyrillaceaepollenites? ventosus ventosus is psilate to weakly punctate, whereas

*Spelling as given by Fairchild and Elsik (1969). 
many gulf coast specimens belong to an unnamed subspecies of $C$. ? ventosus because they are punctate to granulate. No attempt has been made to count specimens of the two subspecies separately. Some specimens assigned to C.? ventosus may represent grains of Quercoidites microhenricii (Potonié) Potonié that happen to lie in polar view. C.? ventosus is also difficult to distinguish from corroded specimens of Cyrillaceaepollenites megaexactus (Potonié) Potonié, which often lie in polar view. The genus Cyrillaceaepollenites was defined to include pollen grains that are psilate or nearly so (Potonié, 1960, p. 102); C.? ventosus is placed here because no more suitable genus is available.

Affinity.-Unknown, probably not Cyrillaceae.

Occurrence._- "Infrequent" to "common" in 52/56 counted samples.

\section{Genus SILTARIA Traverse, 1955}

Remarks. - This genus is used here in a rather broad sense for species having tricolporate punctate grains. That is, the design is too fine for one to say that the grains are either reticulate or granulate. In Horniella Traverse, 1955, Caprifoliipites Wodehouse, 1933, Ailanthipites Wodehouse, 1933, and Rhoipites Wodehouse, 1933, the grains are distinctly reticulate; in Araliaceoipollenites Potonié, 1960, they are distinctly granulate.

\section{Siltaria pacata (Pflug) n. comb.}

Plate 11, figure 25

Tricolporopollenites pacatus Pflug in Thomson and Pflug, 1953, p. 99, pl. 12, figs. 118-121 (basionym).

Ailanthipites pacatus (Pflug) Potonié, 1960, p. 96.

Remarks. - This species is most similar to Cyrillaceaepollenites kedvesii $\mathrm{n}$. sp., but in contrast to the latter, S. pacata has distinct columellae and a sharply punctate design.

Affinity.-Probably Diospyros (Ebenaceae), though Kedves (1969, p. 27) suggested an affinity with Simaroubaceae or Cornaceae.

Occurrence.- "Infrequent" to "occasional" in 6/56 counted samples from the upper part of the Claiborne Group to the lower part of the Vicksburg Group.

\section{Siltaria cf. S. scabriextina Traverse}

Plate 11, figures 26-28

Siltaria scabriextima Traverse, 1955, p. 51, fig. 10 (50).

Cupuliferoipollenites sp. Tschudy and Van Loenen, 1970, pl. 4, figs. 15-16.

Remarks. - The designation Siltaria cf. S. scabriextima is used for grains that are prolate, are tricolporate with lalongate ora, are distinctly columellate, and have a punctate design. However, they are $25 \mu \mathrm{m}$ or less long, whereas $S$. scabriextima is about $32 \mu \mathrm{m}$ long. Rhoipites pseudocingulum (Potonié, 1931a) Potonié, 1960, appears to be similar to $S$. scabriextima, and the two species may be synonymous, but the morphology of the former is less well known than that of the latter. The originally illustrated specimens of $R$. pseudocingulum (Potonié, 1931a, pl. 1, figs. 3-4) are $25 \mu \mathrm{m}$ and $27 \mu \mathrm{m}$ in length, respectively, and Thomson and Pflug (1953, p. 99) defined the species as being $25-40 \mu \mathrm{m}$. It is difficult to determine from the photomicrographs whether the original specimens of $R$. pseudocingulum are columellate or not. Thomson and Pflug (1953, p. 99) described the specimens that they attributed to this species as not having columellae. However, when Potonié $(1960$, p. 101) reassigned Pollenites pseudocingulum to Rhoipites, he defined the latter genus as having an exine that is "fein infrareticulat," which implies the presence of distinct columellae. Affinity.-Possibly Rhus (Anacardiaceae).

Occurrence. - "Infrequent" to "common" in 21/56 counted samples from the upper part of the Claiborne Group to the lower part of the Vicksburg Group.

\section{Genus ARALIACEOIPOLlenITES Potonié, 1960}

Araliaceoipollenites granulatus (Potonié) n. comb.

Plate 11, figures 29-30

Pollenites pseudocingulum granulatum Potonié, 1931a, p. 332, pl. 1, figs. 2, 6, 19, 24, 26-27 (basionym).

Remarks.-Plate 1, figure 6 of Potonié (1931a) is herewith designated the lectotype, as Potonié did not designate a holotype. Rhoipites pseudocingulum (Potonié, 1931a) Potonié, 1960, is punctate or finely reticulate and is distinct from the granulate Araliaceoipollenites granulatus, which is here raised to species level. A. granulatus intergrades with Horniella modica (Mamezar, 1960) n. comb. If the LO-pattern predominated or was equally as distinct as the OL-pattern, the specimens were assigned to $A$. granulatus; if the OL-pattern was stronger, they were assigned to Horniella modica.

Affinity.-Unknown; possibly Fagaceae.

Occurrence.- "Infrequent" to "abundant" in 50/60 counted samples.

\section{Araliaceoipollenites megaporifer $\mathbf{n}$. sp.}

Plate 11, figures 31-32; plate 12, figure 1

Tricolporites sp. (?Araliaceoipollenites). Tschudy and Van Loenen, 1970, pl. 4, figs. 22a-b.

Description.-Size 14-29 $\mu \mathrm{m}$, mean $23 \mu \mathrm{m}$, holotype $26 \mu \mathrm{m}$. Tricolporate. Subprolate to prolate, mostly prolate; outline oval with rounded ends. Exine about $1 \mu \mathrm{m}$ thick, columellate; sexine:nexine ratio 2:1. In some specimens, the exine thickens from slightly less than $1 \mu \mathrm{m}$ at the equator to slightly more than $1 \mu \mathrm{m}$ at the poles because of a thickening of the endosexine. Design granulate; surface rough. Colpi very narrow and extending from three-fourths of the length of the grain to the full 
length; thickenings of colpi margines $0.3-1 \mu \mathrm{m}$ wide. Ora round, $2.5-4 \mu \mathrm{m}$ in diameter, extending beyond the colpi margines.

Holotype.-Plate 11, figures 31-32, slide 10434 A-1, coordinates $41.3 \times 124.7$, Shubuta Member of the Yazoo Clay at Little Stave Creek, Clarke County, Ala.

Remarks. - This species appears to be very similar to Tricolporopollenites microporifer Takahashi, 1961, except that in the latter the ora are smaller, not extending beyond the colpi margines.

Affinity.-Unknown.

Occurrence. - "Infrequent" to "occasional" in 17/56 counted samples from the upper part of the Claiborne Group to the lower part of the Vicksburg Group.

\section{Arahiaceoipollenites profundus n. sp.}

Plate 12, figures $2-4$

Tricolpopollenites spp. of the T. henrici type. Tschudy, 1973, p. B16, pl. 4, figs. 10-11.

Description. -Size 33-58 $\mu \mathrm{m}$, mean $45 \mu \mathrm{m}$, holotype $41 \mu \mathrm{m}$. Tricolporate. Subprolate to perprolate, mostly prolate; outline lenticular with pointed to slightly flattened ends. Exine 1.5-2.5 $\mu \mathrm{m}$ thick, tegillate; ectosexine $0.5 \mu \mathrm{m}$ thick, endosexine $0.5-1.5 \mu \mathrm{m}$ thick, nexine about $0.25-0.5 \mu \mathrm{m}$ thick. Design distinctly granulate to coarsely punctate or finely reticulate. Culpi extending nearly from pole to pole, very narrow and deeply invaginated almost to the polar axis; ora round to lolongate, $4-6 \mu \mathrm{m}$ long, often indistinct.

terized by its moderately large size, rather indistinct ora, and long, very deeply invaginated colpi (profundus, L. “deep"). Araliaceoipollenites edmundii (Potonié, 1931d) Potonié, 1960, and Cornus bremanoirensis Simpson, 1961, have shallower colpi. Yeguapollis colporatus Elsik, 1974b, is similar in several ways to $A$. profundus, but in the former, the exine is thickened at the poles, the ora are more distinct, an endannulus is present, and the design is finer.

Affinity._Euphorbiaceae, very similar to Euphobia and Hippomane.

Occurrence. - "Infrequent" to "occasional" in 22 or 23/56 counted samples from the Moodys Branch Formation to the lower part of the Vicksburg Group; possibly present in the Cockfield Formation. The species ranges down to the Sparta Sand of the Claiborne Group (Tschudy, 1973, p. B16, pl. 4, figs. 10-11).

\section{Genus FOVEOTRICOLPORITES Pierce, 1961}

\section{Foveotricolporites sp.}

Plate 12, figures 5-9

Description.-Size 46-54 $\mu \mathrm{m}$ (three specimens). Prolate; outline elliptical. Tricolporate; colpi narrow, extending nearly full length of grain; ora lolongate, 0.5
$1.5 \mu \mathrm{m}$ wide, $0.5-3 \mu \mathrm{m}$ deep, and $5-8 \mu \mathrm{m}$ long. Exine $2 \mu \mathrm{m}$ thick, tegillate, ectosexine:endosexine:nexine ratio 2:1:2. Foveolate, the foveolae about $0.3 \mu \mathrm{m}$ in diameter.

Remarks. - Foveotricolporites rhombohedralis Pierce, 1961, is prolate spheroidal; Araliaceoipollenites profun$d u s \mathrm{n}$. sp. is granulate to coarsely punctate, and the ora are rounder and less slitlike; Tricolporopollenites hoshuyamaensis foveolatus Takahashi, 1961, is more broadly elliptical in outline, and the ora are round.

Affinity.-Quite possibly Cornaceae.

Occurrence.-Observed in three samples from the Forest Hill Sand of western Mississippi and the Red Bluff Clay of eastern Mississippi.

\section{Genus ILEX Linnaeus \\ Ilex infissa $n$. sp. \\ Plate 12, figures 10-14}

Description.-Size 19-28 $\mu \mathrm{m}$, mean $24 \mu \mathrm{m}$, holotype $28 \mu \mathrm{m}$. Prolate spheroidal to subprolate. Tricolporate; colpi narrow (0.5-1 $\mu \mathrm{m}$ wide), rather deeply invaginated, extending nearly full length of grain, bordered on each side by thickenings $2 \mu \mathrm{m}$ wide; ora distinct, lalongate, slitlike, $0.5 \mu \mathrm{m}$ wide and 3.5-5 $\mu \mathrm{m}$ long, cutting through marginal thickenings of colpi. Exine 1.5-2 $\mu \mathrm{m}$ thick, sexine:nexine ratio $2: 1$, densely clavate, the clavae 1.3-2 $\mu \mathrm{m}$ long.

Holotype.-Plate 12 , figures $10-12$, slide $10864 \mathrm{~A}-$ 2, coordinates $23.5 \times 116.9$, Yazoo Clay, Hole AF-40, Hinds County, Miss.

Remarks.-Ilex infissa is characterized by its distinct slitlike ora and the low ratio of polar axis:equatorial axis. The specific epithet (infissus, Latin, "cut through") refers to the cutting of the ora across the colpi margines.

Occurrence.- "Infrequent" in five counted samples from the Gosport Sand of western Alabama and the Yazoo Clay of western Mississippi. Some specimens were also observed in a lignite sample from the type Forest Hill Sand (loc. 4).

\section{Ilex nedia (Pflug and Thonison) n. comb.}

Plate 12, figures $15-16$

Tricolporopollenites iliacus medius Pflug and Thomson in Thomson and Pflug, 1953, p. 106, pl. 14, figs. 46-60 (basionym).

Ilexpollenites $\mathrm{cf}$. I. iliacus (R. Potonié, 1931) Thiergart, 1937.* Engelhardt, 1964a, p. 73, pl. 2, fig. 22.

Ilexpollenites sp. Tschudy and Van Loenen, 1970, pl. 4, figs. 19, ?18.

Remarks. - The holotype of Ilex iliaca (Potonié, 1931c) Martin and Rouse, 1966, has massive elements and is more gemmate than clavate. Tricolporopollenites iliacus medius has thin clavae and is here raised to species level and transferred to Ilex. Pflug and Thomson (in Thomson

*Date given by Engelhardt (1964a, p. 73) for a separate issue in 1937; journal was published in 1938. 
and Pflug, 1953) gave a size range of $25-45 \mu \mathrm{m}$ for $T$. iliacus medius; my specimens have a size range of $15-$ $30 \mu \mathrm{m}$.

Occurrence. - "Infrequent" to "occasional" in $46 / 56$ counted samples from the upper part of the Claiborne Group to the lower part of the Vicksburg Group.

\section{Genus VERRUTRICOLPORITES van der Hanınien and Wijmstra, 1964 \\ Verrutricolporites cruciatus n. sp. \\ Plate 12, figures 17-19 \\ Tricolporopollenites spp. Tschudy, 1973, p. B15, pl. 3, figs. 17-19?}

Description.-Size 26-34 $\mu \mathrm{m}$, mean $29 \mu \mathrm{m}$, holotype $31 \mu \mathrm{m}$. Prolate; outline oval with rounded to slightly pointed ends. Tricolporate; colpi narrow, extending about four-fifths the length of grain, edges thickened little or not at all; ora distinct, lalongate, $1-3 \mu \mathrm{m} \times 3-8 \mu \mathrm{m}$. Exine $1.5-2 \mu \mathrm{m}$ thick including ornamentation; sexine:nexine ratio 1:1; verrucate, the elements irregular in design, about $0.5-1 \mu \mathrm{m}$ in diameter and $0.3-0.5 \mu \mathrm{m}$ high; negative reticulum rather well developed.

Holotype.-Plate 12, figures 17-18, slide 10642 A2 , coordinates $21.4 \times 125.3$, Moodys Branch Formation at Jackson, Miss.

Remarks.-Verrutricolporites cruciatus is characterized by its lalongate ora and negative reticulum and by the fact that the colpi edges are not greatly thickened. The epithet cruciatus (Latin, "cross") refers to the crosses made by the lalongate ora with the colpi. This species might be synonymous with Pollenites rauffii $\mathrm{Po}$ tonié, 1931a, but the holotype of $P$. rauffii is difficult to interpret. The forms called Pollenites pseudocingulum rauffii (Potonié) by Potonié (1934), from the type locality of $P$. rauffii, have round ora and thick colpi margines. These specimens may be different from the holotype of Pollenites rauffii, and they are quite different from Verrutricolporites cruciatus. Pollenites navicula Potonié, 1931a, also has thick colpi margines.

Affinity.-Unknown.

Occurrence. - "Infrequent" to "common" in $42 / 56$ counted samples from the upper part of the Claiborne Group to the lower part of the Vicksburg Group.

\section{Verrutricolporites ovalis (Potonié) n. conb.}

Plate 12, figures 20-21

Pollenites cingulum ovalis Potonié, 1934, p. 83, pl. 4, fig. 8 (basionym).

Tricolporopollenites sp. 5. Engelhardt, 1964a, p. 74, pl. 3, fig. 30 .

Tricolporate, rugulose-verrucose pollen. Fairchild and Elsik, 1969, pl. 37, fig. 18.

Unidentified tricolporate pollen having relatively coarse verrucose-rugulose ornament. Elsik, 1974b, pl. 4, fig. 119.

Remarks. - This species is distinguished by the large size of the verrucae. In Pollenites cingulum Potonié, 1931d, the exine is granulate, and Verrutricolporites ovalis thus belongs to a different genus than $P$. cingulum.

Affinity.-Unknown.

Occurrence. - "Infrequent" in two counted samples of Yazoo Clay; also observed in an uncounted sample from the Red Bluff Clay.

\section{Verrutricolporites tenuicrassus n. sp. \\ Plate 12, figures 22-25}

Description.-Size 23-34 $\mu \mathrm{m}$ (five specimens), holotype $31 \mu \mathrm{m}$. Prolate, outline oval. Tricolporate; colpi $0.5-1 \mu \mathrm{m}$ wide, extending nearly full length of grain; ora lolongate, about $3 \times 6 \mu \mathrm{m}$. Exine $0.7-1.2 \mu \mathrm{m}$ thick at equator and $2-3 \mu \mathrm{m}$ thick at poles; sexine:nexine ratio 2-3:1; verrucate, the elements irregular in design, $0.5-1 \mu \mathrm{m}$ in diameter and $0.2-0.5 \mu \mathrm{m}$ high; negative reticulum present; exine may be indistinctly tegillate.

Holotype.-Plate 12, figures 22-23, slide 10663 A-1, coordinates $18.0 \times 115.3$, Moodys Branch Formation near Rose Hill, Jasper County, Miss.

Remarks.-Verrutricolporites tenuicrassus is characterized by having a thicker exine at the poles (crassus, Latin, "thick") than at the equator (tenuis, Latin, "thin") and by having lolongate ora.

Affinity.-Possibly Fagaceae.

Occurrence. - "Infrequent" in three samples from the Moodys Branch Formation and the lower part of the Yazoo Clay of Mississippi.

\section{Genus NUXPOLLENITES Elsik, 1974b}

\section{Nuxpollenites sp. \\ Plate 12, figures 26-27}

Nuxpollenites sp. Elsik, 1974b, pl. 4, figs. 138-140.

Description.-In this species, the large verrucae are present over the whole exine, but they are larger and higher at the poles than at the equator. My specimen is $29 \mu \mathrm{m}$ in length overall.

Remarks. -Nuxpollenites crockettensis Elsik, 1974b, has fewer but larger verrucae.

Affinity.-Possibly Phoradendron (Loranthaceae) according to Elsik (1974b, p. 100).

Occurrence.-One specimen observed from the Gosport Sand at Little Stave Creek. Elsik's (1974b, pl. 4, figs. 138-140) specimen is from the Cook Mountain Formation (middle Eocene) of Texas (W. C. Elsik, written commun., 1976).

\section{Genus NYSSA Linnaeus}

Nyssa kruschii (Potonie) n. conıb.

Plate 13, figure 1

Pollenites kruschi Potonié, 1931b, p. 4, fig. 11 (basionym).

Tricolporopollenites kruschi (Potoniè) Thomson and Pflug, 1953, p. 103 , pl. 13, figs. 14-63. 
Nyssapollenites ef. N. accessorius (R. Potonié, 1934) R. Potonié, 1950.* Engelhardt, 1964a, p. 74, pl. 3, fig. 33.

Tetracolporites sp. Engelhardt, 1964a, p. 76, pl. 4, fig. 50 .

Nyssa sp. Fairchild and Elsik, 1969, p. 84, pl. 37, fig. 16.

Remarks. -This species has long colpi with broad sexinal thickenings of the margines and also nexinal thickenings around the ora; the ora form more than half a circle in optical section and equatorial view; the reticulum is very fine. My specimens range from 21 to $42 \mu \mathrm{m}$ and thus include several subspecies of $N$. kruschii as defined by Potonié (1934) and Thomson and Pflug (1953).

Occurrence. - "Infrequent" to "occasional" in $41 / 56$ counted samples from the upper part of the Claiborne Group to the lower part of the Vicksburg Group. This species apparently ranges down into the Wilcox Group (Fairchild and Elsik, 1969, p. 84).

\section{Genus NYSSAPOLLENITES Potonie 1960}

Nyssapollenites Potonié, 1960, p. 103-104.

Nyssoidites Potonié, 1960, p. 104.

Remarks. -The validation of the genera Nyssapollenites and Nyssoidites was discussed by Jansonius and Hills (1976, cards 1794-1795). The type species do not appear to be different enough to warrant placing them in separate genera.

Nyssapollenites pulvinus (Potonié) n. conb.

Plate 12, figures 28-29

Pollenites pulvinus Potonié, 1931b, p. 4, fig. 23 (basionym).

Remarks.-Pollenites pseudocruciatus pantherinus Potonie, 1934, may be synonymous with this species.

Affinity.-Perhaps Nyssaceae or Cornaceae.

Occurrence.- "Infrequent" to "occasional" in 20/56 counted samples from the upper part of the Claiborne Group to the lower part of the Vicksburg Group.

\section{Genus RHOIPITES Wodehouse, 1933}

\section{Rhoipites angustus n. sp.}

Plate 13, figures 2-8

Tricolporopollenites dolium (R. Potonié, 1931) Thomson and Pflug, 1953 [misidentified]. Engelhardt, 1964a, p. 73, pl. 2, fig. 21.

Tricolporopollenites kruschii (Potonié, 1934) Thomson and Pflug 1953. Elsik, 1968b, p. 628, pl. 34, figs. 3a-b only.

Description.-Size 24-35 $\mu \mathrm{m}$, mean $29 \mu \mathrm{m}$, holotype $32 \mu \mathrm{m}$. Prolate spheroidal to prolate; outline oval to diamond shaped, poles rounded to somewhat flattened. Tricolporate; colpi about three-fourths the length of the grain and very narrow (sides of colpi may be pressed together), exine not thinned along colpi so that colpi walls appear very thick; ora distinct, round, $2-2.5 \mu \mathrm{m}$ in di-

*Date given by Engelhardt (1964a, p. 74) is 1950; correct date is 1951. ameter, endannuli apparently lacking. Exine $1 \mu \mathrm{m}$ thick, minutely reticulate.

Holotype.-Plate 13, figure 2, slide $10553 \mathrm{~A}-1$, coordinates 45.5 $\times$ 118.0, Moodys Branch Formation at Little Stave Creek, Clarke County, Ala.

Remarks.-The specific epithet (angustus, Latin, "narrow, confined") refers to the very narrow colpi in this species. Tricolporopollenites kruschii contortus Pflug and Thomson in Thomson and Pflug, 1953, probably has a different design and does not appear to have thick exine around the colpi; Rhoipites bradleyi Wodehouse, 1933, apparently has lalongate ora and a slightly coarser infra?-reticulation. Nyssa kruschii (Potonié, 1931b) n. comb. is spheroidal to oblate, but otherwise it is similar to Rhoipites angustus in many respects.

Affinity.-Mastixia (Cornaceae) and Nyssa (Nyssaceae) are similar, but the modern grains of both genera are endannulate; Rhus barclayi Standley (Anacardiaceae) is also similar.

Occurrence.- "Infrequent" to "common" in 49/56 counted samples from the upper part of the Claiborne Group to the lower part of the Vicksburg Group. The species may range down into the Paleocene (see Elsik, 1968b, p. 628, pl. 34, figs. 3a, b).

\section{Rhoipites latus n. sp.}

Plate 13, figures 9-13

Tricolporopollenites sp 4. Engelhardt, 1964a, p. 74, pl. 3, fig. 29.

Tricolpopollenites sp. Tschudy and Van Loenen, 1970, pl. 4, figs. $13 \mathrm{a}-\mathrm{b}$.

Tricolporites sp. Tschudy and Van Loenen, 1970, pl. 5, fig. 1.

Tricolporopollenites $\mathrm{n}$. sp. B (Parthenocissus type). Tschudy, 1973, p. B17, pl. 4, figs. 18-19.

Description.-Size 34-44 $\mu \mathrm{m}$, mean $39 \mu \mathrm{m}$, holotype $42 \mu \mathrm{m}$. Prolate; outline oval. Tricolporate; colpi deep, narrow, extending nearly full length of grain, bordered by thickenings $1.5-2 \mu \mathrm{m}$ wide; ora distinct and round, slightly lalongate or slightly lolongate, $2.5-3.5 \mu \mathrm{m}$ in greatest dimension, wider than colpi and creating depressions in marginal thickenings. Exine exclusive of ornamentation $0.5-0.7 \mu \mathrm{m}$ thick. Exine reticulate; muri coarsely clavate in cross section, clavae $1.5 \mu \mathrm{m}$ high, thin baculae present between clavae; muri duplibaculate, 0.5$0.8 \mu \mathrm{m}$ thick and wide; lumina polygonal to longitudinally elongate, $0.5-1.5 \mu \mathrm{m} \times 1-2.5 \mu \mathrm{m}$.

Holotype.-Plate 13, figures 9-10, slide $10662 \mathrm{~A}-1$, coordinates $22.1 \times 126.0$, Moodys Branch Formation near Rose Hill, Jasper County, Miss.

Remarks. - The name (latus, Latin, "wide") refers to the wide muri in the species. Horniella secreta (Doktorowicz-Hrebnicka, 1960) n. comb. is typically subprolate in shape, has more lalongate ora and lacks wide marginal thickenings of the colpi; Horniella sp. A also lacks the marginal thickenings and has narrower muri; Tricolporopollenites helmstedtensis Pflug in Thomson and Pflug, 
1953 , has an indistinct reticulum. Rhoipites cryptoporus Srivastava, 1972, has larger ora (3-4 $\mu \mathrm{m}$ in diameter) and is prolate to prolate spheroidal.

Affinity.-Tschudy and Van Loenen (1970, pl. 5, fig. 1) and Tschudy (1973, p. B17, pl. 4, figs. 18-19) noted a similarity of this species to pollen of Parthenocissus (Vitaceae).

Occurrence.- "Infrequent" to "occasional" in 44/56 counted samples from the upper part of the Claiborne Group to the lower part of the Vicksburg Group.

\section{Rhoipites subprolatus n. sp. \\ Plate 13, figures $14-16$}

Description.-Size 23-33 $\mu \mathrm{m}$ (five measured specimens), holotype $33 \mu \mathrm{m}$. Subprolate; outline broadly oval. Tricolporate; colpi deep and very narrow, extending nearly full length of grain, bordered by thickenings 1$1.5 \mu \mathrm{m}$ wide; ora rather indistinct, round, $2-3 \mu \mathrm{m}$ in diameter, cutting part way into the marginal thickenings. Exine excluding ornamentation $0.5 \mu \mathrm{m}$ thick. Exine minutely reticulate; muri finely and densely clavate in optical section, clavae $1.5 \mu \mathrm{m}$ high, muri $0.5 \mu \mathrm{m}$ thick.

Holotype.-Plate 13, figures 15-16, slide 10643 A-1, coordinates $34.4 \times 121.0$, Moodys Branch Formation at Jackson, Miss.

Remarks.-Rhoipites subprolatus is distinguished by its thick, very finely reticulate ornamentation and its subprolate shape (to which the specific epithet refers).

Affinity.-Unknown.

Occurrence.- "Infrequent" in eight counted samples from the Gosport Sand to the Yazoo Clay.

\section{Genus HORNIELLA Traverse, 1955}

Remarks. - This genus includes prolate to spheroidal, tricolporate, reticulate grains with distinct, lalongate to round ora. In Caprifoliipites Wodehouse, 1933, the ora are rather obscure; Ailanthipites Wodehouse, 1933, includes retistriate and striate grains; in Rhoipites Wodehouse, 1933, the colpi are bordered by conspicuous thickenings.

\section{Iorniella genuina (Potonié) n. comb.}

Plate 13, figures $17-18$

Pollenites genuinus Potonié, 1934, p. 95-96, pl. 5, figs. 22, 30-32, 34; pl. 6, fig. 34 (basionym).

Tricolporopollenites genuinus (Potonié) Thomson and Pflug, 1953, p. 105 , pl. 13 , figs. $69-85$.

Tricolporopollenites hoshuyamaensis fossulatus Takahashi, 1961, p. 325, pl. 25, figs. 5-9 (=T. hoshuyamaensis hoshuyamaensis Takahashi, 1961, according to Ames and Kremp, 1964, p. 21-113).

Tricolporopollenites sp. 3. Engelhardt, 1964a, p. 73-74, pl. 3, figs. 26-27.

Affinity.-In the Simarubaceae and Anacardiaceae, the reticulation is typically finer. Therefore, the species has been assigned to Horniella rather than to Ailanthipites, even though the lumina are distinctly elongate parallel with the polar axis. Engelhardt (1964a, p. 73-74) noted a similarity of this species with pollen of Belotia, Sparmannia, and Triumfetta, all of the Tiliaceae.

Occurrence.- "Infrequent" in three samples from the Cockfield Formation of western Mississippi and the Gosport Sand and Red Bluff Clay of western Alabama, respectively.

\section{Horniella modica (Mamczar) n. comb.}

Plate 13, figures 19-20

Pollenites modicus Mamczar, 1960, p. 220, pl. 14, fig. 205 (basionym).

Remarks. - This species is distinguished by its small size (about 20-25 $\mu \mathrm{m}$ ), rather fine reticulum, the indistinct, round to somewhat lalongate ora, and the deeply incised colpi.

Affinity.-Unknown; possibly Rutaceae, Anacardiaceae, or Simarubaceae.

Occurrence.- "Infrequent" to "common" in 41/56 counted samples from the upper part of the Claiborne Group to the lower part of the Vicksburg Group.

\section{Iorniella sp. A}

Plate 13, figures 21-23

Rhoipites sp. Tschudy and Van Loenen, 1970, pl. 4, figs. 21a-b.

Description.-Size 24-39 $\mu \mathrm{m}$ (four measured specimens). Subprolate to prolate; outline oval. Tricolporate, colpi extending nearly full length of grain, bordered by thickenings; ora distinct, circular, about $1.5 \mu \mathrm{m}$ in diameter, wider than colpi; endannuli are present in the illustrated specimen but not in the other specimens. Exine excluding ornamentation 0.5 to possibly $1 \mu \mathrm{m}$ thick. Exine reticulate; muri clavate in optical section, clavae 1$1.3 \mu \mathrm{m}$ high; muri $0.4 \mu \mathrm{m}$ wide; lumina average about 1 $\mu \mathrm{m}$ in diameter.

Remarks.-Horniella sp. A is distinguished by its rather narrow muri and medium-sized lumina and by its small round ora. Pollenites formosus Mamczar, 1960, has smaller lumina; Rhoipites latus $\mathrm{n}$. sp. has wider muri; Caprifoliipites incertigrandis $\mathrm{n}$. $\mathrm{sp}$. has larger and less distinct ora.

Affinity.-Pollen of several genera of Vitaceae, illustrated by Straka and Simon (1967, pls. 124/I, figs. 1a-f, and 124/II, figs. 1a-c, 2a-c), are similar to Horniella sp. A in shape, ornamentation, and above all in the long, narrow colpi, with narrow, thickened margines and small, round ora with narrow endannuli.

Occurrence.-Counted together with Caprifoliipites incertigrandis; definitely ranges from the upper part of the Claiborne Group to the lower part of the Vicksburg Group. 
Horniella spp.

Plate 13, figures 24-25

Remarks. - Some of these specimens probably represent Horniella secreta (Doktorowicz-Hrebnicka) n. comb. (basionym: Pollenites secretus Doktorowicz-Hrebnicka, 1960 , p. 115 , pl. 44, fig. 239).

Affinity.-Very similar to pollen of Zanthoxylum (Rutaceae). Some may also have been produced by Araliaceae.

Occurrence.- "Infrequent" in 12/56 counted samples from the upper part of the Claiborne Group to the lower part of the Vicksburg Group.

\section{Genus CAPRIFOLIIPITES Wodehouse, 1933}

Remarks.-In this genus, the grains are prolate to spheroidal, tricolporate and reticulate (not infrareticulate with a smooth surface as stated by Potonié, 1960, p. 97); the ora are rather indistinct in plan view, in contrast to Horniella Traverse, 1955, where the ora are strongly expressed.

\section{Caprifoliipites incertigrandis n. sp.}

Plate 13, figures 26-29

Description.-Size 26-38 $\mu \mathrm{m}$ (nine measured specimens), mean $32 \mu \mathrm{m}$, holotype $28 \mu \mathrm{m}$. Prolate; outline oval. Tricolporate, colpi extending nearly full length of grain, bordered internally by thickenings about $1 \mu \mathrm{m}$ wide; ora rather distinct and semicircular in optical section, indistinct in plan view, probably round to somewhat lalongate, expressed mainly as gaps in marginal thickenings of colpi (pl. 13, figs. 26, 28), about $4-5 \mu \mathrm{m}$ wide. Exine including ornamentation about $1.3 \mu \mathrm{m}$ thick; exine proper $0.3 \mu \mathrm{m}$ thick. Exine reticulate; muri clavate in optical section, clavae $1 \mu \mathrm{m}$ high; muri $0.3-0.4 \mu \mathrm{m}$ wide, lumina $0.5-2 \mu \mathrm{m}$ in diameter, averaging about $1 \mu \mathrm{m}$.

Holotype.-Plate 13, figures 26-27, slide $14963 \mathrm{C}-1$, coordinates $28.4 \times 119.8$, Shubuta Member of the Yazoo Clay at Little Stave Creek, Clarke County, Ala.

Remarks.-Caprifoliipites incertigrandis is characterized by its medium-sized lumina and rather narrow muri and by its large ora which are rather poorly expressed in plan view (incertus, Latin, "obscure"; grandis, Latin, "large," both referring to the ora). Tricolporopollenites sp. 2 of Engelhardt, 1964a, probably belongs to this species. Caprifoliipites viridi-fluminis Wodehouse, 1933, is smaller; Horniella secreta (Doktorowicz-Hrebnicka, 1960) n. comb. has distinct, lalongate ora.

Affinity.-Unknown.

Occurrence.-Counted together with Horniella sp. A; the two species together were "infrequent" to "occasional" in 11/56 counted samples. Caprifoliipites incertigrandis is the more abundant of the two species and probably ranges from the upper part of the Claiborne Group to the lower part of the Vicksburg Group.

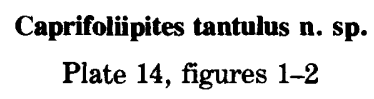

Description.-These grains match perfectly the description of Caprifoliipites microreticulatus (Pflug and Thomson in Thomson and Pflug, 1953) Potonié, 1960, but they are only $14-19 \mu \mathrm{m}$ in greatest dimension (holotype $14 \mu \mathrm{m}$ ), whereas the size of $C$. microreticulatus was given as $18-30 \mu \mathrm{m}$.

Holotype.-Plate 14, figure 1, slide 10637 A-2, coordinates $40.5 \times 122.3$, Yazoo Clay at Jackson, Miss.

Remarks. - The specific epithet (tantulus, Latin, "so small") refers to the small size of the grains in this species. The pollen grain illustrated by Tschudy and Van Loenen (1970, pl. 4, fig. 8) as Tricolpopollenites sp. probably belongs to this species. Caprifoliipites tantulus intergrades morphologically with Salixipollenites parvus n. sp., because in C. tantulus, the ora are small and may be indistinct. However, in C. tantulus, the grains are oblate spheroidal to prolate spheroidal, and the colpi are only one-half to two-thirds the length of the polar axis, whereas in $S$. parvus, the grains are subprolate to prolate, and the colpi are two-thirds to three-fourths the length of the grain.

Affinity.-Possibly Viburnum (Caprifoliaceae).

Occurrence.- "Infrequent" to "occasional" in 21/56 counted samples from the Cockfield Formation to the upper part of the Yazoo Clay.

\section{Genus LONICERAPOLLIS Krutzsch, 1962}

\section{Lonicerapollis sp.}

Tricolpopollenites sp. aff. Caprifoliaceae cf. Lonicera. Tschudy and Van Loenen, 1970, pl. 4, fig. 17.

Affinity.-Pollen of three available species of modern Lonicera all have a shape, exine design and structure, and apertures similar to those of these fossils. However, pollen grains of Triosteum and Linnaea (also Caprifoliaceae) are also similar (Krutzsch, 1962, p. 275).

Occurrence.-Reported by Tschudy and Van Loenen (1970) to be in the upper part of the Yazoo Clay of western Mississippi. I have not seen the species in my material.

\section{Genus AILANTHIPITES Wodehouse, 1933}

Ailanthipites berryi Wodehouse Plate 14, figures 3-6

Ailanthipites berryi Wodehouse, 1933, p. 512, fig. 44.

Tricolporopollenites sp. l. Engelhardt, 1964a, p. 73, pl. 3, fig. 25. 
Remarks.-Distinguishing features of this species are the prolate shape, the distinct, lalongate ora, and the retistriate design.

Affinity.-Similar grains occur in Anacardiaceae (Lithraea, Rhus), Leguminosae (Aphanocalyx, Didelotia), Sapindaceae (Harpullia), and Simarubaceae (Ailanthus).

Occurrence. - "Infrequent" to "occasional" in 19/56 counted samples from the upper part of the Claiborne Group to the lower part of the Vicksburg Group.

\section{Genus RETITRESCOLPITES Sah, 1967}

Remarks.-Potonie $(1960$, p. 95$)$ emended the diagnosis of Tricolpites Couper, 1953, restricting the genus to finely reticulate grains. Later, Belsky and others (1965, p. 75) again emended the genus, enlarging it to include both coarsely and finely reticulate forms. Srivastava $(1969$, p. 55) rejected the latter emendation. As a result, coarsely reticulate forms of oblate, tricopate pollen (that is, pollen having lumina greater than $1 \mu \mathrm{m}$ in diameter) are now placed in the genus Retitrescolpites.

\section{Retitrescolpites sp.}

Tricolpites thomasii Cookson and Pike, 1954 [misidentified]. Engelhardt, 1964a, p. 72, pl. 2, fig. 17.

Tricolporites sp. (?Anacardiaceae cf. Spondias. See Tsukada, 1964). Tschudy and Van Loenen, 1970, pl. 4, fig. 29.

Remarks.-This species does not belong to Tricolpites thomasii as suggested by Engelhardt (1964a), because the polar areas are distinctly reticulate like the rest of the exine, whereas in $T$. thomasii, the polar areas are nearly smooth.

Occurrence.-Reported to be from the upper part of the Cockfield Formation and upper part of the Yazoo Clay of western Mississippi by Engelhardt (1964a) and Tschudy and Van Loenen (1970), respectively. I have not observed the species in my material.

\section{Genus ALANGIOPOLLIS Krutzsch, 1962a}

\section{Alangiopollis sp.}

Plate 14, figures $7-8$

Description. - Size $42-46 \mu \mathrm{m}$ (two specimens). Oblate spheroidal to suboblate; outline more or less round. Tricolporate; colpi extend about two-thirds the distance to poles, bordered by thickenings 1-2.5 $\mu \mathrm{m}$ wide; ora round, 4-10 $\mu \mathrm{m}$ in diameter. Exine excluding ornamentation $1 \mu \mathrm{m}$ thick. Exine reticulate; muri clavate in optical section, clavae $1.5 \mu \mathrm{m}$ high, muri $0.5 \mu \mathrm{m}$ wide and duplibaculate; lumina 1-2 $\mu \mathrm{m}$ in diameter.

Remarks.-Alangiopollis javanicoides (Cookson, 1957) Krutzsch, 1962, is larger and has a finer reticulum; A. barghoorniana (Traverse, 1955) Krutzsch, 1962, is larger and has a coarser reticulum in which the lumina are radially elongate. The specimen called Alangiopollis barghoorniana? by Krutzsch (1962, pl. 7, figs. 6-9) may belong to Alangiopollis sp.

Affinity.-Alangiaceae, probably Alangium.

Occurrence.- "Infrequent" in two to four samples from the Gosport Sand to the Yazoo Clay.

\section{Genus MYRTACEIDITES Cookson and Pike, 1954}

\section{Myrtaceidites parvus Cookson and Pike}

Plate 14, figures 9-11

Myrtaceidites parvus Cookson and Pike, 1954, p. 206, pl. 1, figs. 2731.

Myrtaceidites parvus nesus Cookson and Pike, 1954, p. 206, pl. 1, figs. 29-31.

Myrtaceidites parvus anesus Cookson and Pike, 1954, p. 206, pl. 1, figs. 27-28.

Cupanieidites sp. Tschudy and Van Loenen, 1970, pl. 4, figs. 23-24.

Remarks.-Grains in this species are smaller than grains in Cupanieidites orthoteichus Cookson and Pike, 1954, the corners are more broadly rounded, and the exine is psilate to punctate rather than reticulate. Cookson and Pike did not designate a holotype for $M$. parvus. Plate 1, figure 29 of Cookson and Pike (1954) is herewith designated as the lectotype. Myrtaceidites parvus nesus thus becomes $M$. parvus parvus. A third subspecies appears to be present in my material (pl. 14, fig. 11); this has polar islands that are sharply infra?-granulate and are not delimited by the colpi, which reach only to the edge of the islands. The three subspecies were counted together.

Affinity.-Probably Myrtus and (or) Eugenia (Myrtaceae).

Occurrence.— "Infrequent" to "occasional" in $19 / 56$ counted samples from the upper part of the Claiborne Group to the lower part of the Vicksburg Group.

\section{Genus CUPANIEIDITES Cookson and Pike, 1954 eniend. Chniura,} 1973

Cupanieidites Cookson and Pike, 1954, p. 210, pl. 2, figs. 73-78, 8385, 87-89.

Duplopollis Krutzsch, 1959b, p. 144, pl. 34, figs. 25-44; text-fig. 13.

\section{Cupanieidites orthoteichus Cookson and Pike}

Plate 14 , figure 12

Cupanieidites orthoteichus Cookson and Pike, 1954, p. 213, pl. 2, figs. 73-78.

Duplopollis orthoteichus (Cookson and Pike) Krutzsch, 1959b, p. 145. Duplopollis myrtoides Krutzsch, 1959b, p. 145, pl. 34, figs. 25-44; text-fig. 13.

Cupanieidites orthoteichus Cookson and Pike, 1954. Engelhardt, 1964a, p. $74-75$, pl. 3 , fig. 34 .

Duplopollis sp. Fairchild and Elsik, 1969, p. 84, pl. 37, fig. 19. Duplopollis sp. Tschudy and Van Loenen, 1970, pl. 4, figs. 25-27.

Remarks.—Krutzsch (1959b) designated plate 2, figure 76, of Cookson and Pike (1954) as the lectotype of Cupanieidites orthoteichus. This specimen is an end member of the species, having distinct and almost coarse 
reticulation. My specimens are similar to all those of Cookson and Pike; that is, they range from sharply to very indistinctly reticulate. Krutzsch's 'species Duplopollis myrtoides falls within this range of variation.

Affinity.-Specimens of this species from the Tertiary of southeastern North America undoubtedly represent Cupania (Sapindaceae) at least in part. Amyema subalata (De Wild.) Danser (Loranthaceae) is also very similar (Van Campo, 1966, pl. 2, fig. 14).

Occurrence._- "Infrequent" in 16/56 counted samples from the upper part of the Claiborne Group to the top of the Yazoo Clay.

\section{Genus BOEHLENSIPOLLIS Krutzsch, 1962}

\section{Boehlensipollis hohlii Krutzsch}

Plate 14, figures 13-14

Boehlensipollis hohli Krutzsch, 1962, p. 272, text-fig. 2; pl. 3, figs. $18-30$.

Remarks.-This species is distinguished by its triangular shape with narrowly rounded corners, syncolporate apertures, and granulate to punctate design.

Affinity.-Elaeagnaceae.

Occurrence._-"Infrequent" to "occasional" in 29/56 counted samples from the upper part of the Claiborne Group to the lower part of the Vicksburg Group, especially in Mississippi.

\section{Genus GOTHANIPOLLIS Krutzsch, 1959a}

Gothanipollis cockfieldensis Engellardt

Plate 14, figure 16

Gothanipollis sp. 1. Engelhardt, 1964a, p. 75, pl. 3, figs. 35-37.

Gothanipollis cockfieldensis Engelhardt, 1964b, p. 598-600, pl. 1, figs. $1-4$.

Gothanipollis sp. Fairchild and Elsik, 1969, p. 84, pl. 37, fig. 20.

Gothanipollis sp. Tschudy, 1973, p. B16, pl. 4, fig. 4 only.

Remarks. - This species is triangular with straight to concave sides and blunt corners that have flaring tips; it is syncolporate and punctate to weakly granulate.

Affinity._Perhaps Loranthus (Loranthaceae); similar to pollen of Loranthus eugenioides Humboldt, Bonpland, and Kunth illustrated by Kuprianova (1966, pl. 2, fig. 9).

Occurrence. - "Infrequent" in 8 or $9 / 56$ counted samples from the upper part of the Claiborne Group to the Yazoo Clay.

\section{Genus BOMBACACIDITES Couper, 1960 emend. Krutzsch, 1970b}

\section{Bombacacidites nacimientoensis (Anderson) Elsik}

Plate 14, figure 15

Bombacacidites nacimientoensis Anderson, 1960, p. 23, pl. 8, fig. 13. Bombacacidites nacimientoensis (Anderson, 1960) Elsik, 1968b, p. 620 , pl. 22, figs. 1-2, 4.

Bombacacidites sp. Tschudy and Van Loenen, 1970, pl. 5, figs. 17-19.
Remarks.-In this species, the outline is triangular with nearly straight sides and rather narrowly rounded corners; grain is planaperturate and has a reticulum that is rather coarse over most of the exine but becomes much finer at the corners.

Affinity.-Probably Bombacaceae (Krutzsch, 1970b, p. 280).

Occurrence.- "Infrequent" in 14/56 counted samples from the upper part of the Claiborne Group to the lower part of the Vicksburg Group.

\section{Genus TILIA Linnaeus}

Tilia instructa (Potonié) n. comb.

Plate 14, figures 21-22

Tiliae-pollenites instructus Potonié, 1931c, p. 556, fig. 9 (basionym). Intratriporopollenites instructus (Potonié) Thomson and Pflug, 1953, p. 89, pl. 10, figs. 14-23.

Tiliaepollenites cf. T. instructus (R. Potonié, 1931) Potonié and Venitz, 1934. Engelhardt, 1964a, p. 77, pl. 5, fig. 56.

Tiliaepollenites sp. Tschudy and Van Loenen, 1970, pl. 5, figs. 16a-b.

Remarks.-This species is characterized by its rather large size, very fine reticulum, and broadly rounded triangular shape. Photographs of the holotype and other specimens of this species appear in Mai, 1961 (pl. 12, figs. $1-18)$.

Occurrence. - "Infrequent" in 17/56 counted samples from the upper part of the Claiborne Group to the lower part of the Vicksburg Group.

\section{Genus INTRATRIPOROPOLLENITES Pflug and Thomson in Thomson and Pflug, 1953}

Remarks.-Mai (1961, p. 58) showed that the genus Tiliae-pollenites Potonié, $1931 \mathrm{~b}$, must be rejected because it is based on a modern grain of Tilia which became mixed in with the fossils.

\section{Intratriporopollenites stavensis $\mathbf{n}$. sp.}

Plate 14 , figures $17-20$

Tiliaepollenites sp. Engelhardt, 1964a, p. 77, pl. 4, fig. 48.

Tiliaepollenites sp. Tschudy and Van Loenen, 1970, pl. 5, figs. 13, ?11a-b, ?14-15.

Description.-Size 16-31 $\mu \mathrm{m}$, mean $25 \mu \mathrm{m}$, holotype $24 \mu \mathrm{m}$. Tricolporate, rarely tetracolporate (pl. 14, figs. $19,20)$. Peroblate; outline rounded triangular, occasionally nearly round. Exine $1 \mu \mathrm{m}$ thick including ornamentation; sexine:nexine ratio $2-3: 1$. Sexine reticulate, the muri about $0.3 \mu \mathrm{m}$ wide and slightly clavate in optical section, rising $0.5 \mu \mathrm{m}$ or less above exine surface. Lumina polygonal, about $1 \mu \mathrm{m}$ in diameter, with a small granum in the center of each lumen. Sexine slightly overhangs apertures; colpi and ora 1-2 $\mu \mathrm{m}$ wide at equator; reticulum extends to edges of apertures. Nexine at the apertures thickens perpendicular to sexine; nexine (endannulus) $1.5-2.5 \mu \mathrm{m}$ thick around vestibula, thinning slightly toward bases of vestibula. 
Holotype.-Plate 14, figure 17, slide 10547 A-2, coordinates $28.4 \times 112.6$, North Twistwood Creek Member of the Yazoo Clay at Little Stave Creek, Clarke County, Ala.

Remarks.—Tilia crassipites Wodehouse, 1933, is larger; Intratriporopollenites neumarkensis Mai, 1961, has a thinner endannulus and a different aperture structure; Bombacacidites reticulatus Krutzsch, 1961, also has a thinner endannulus, and it lacks the granum in the center of each lumen.

Affinity.-Probably Tiliaceae (a similar aperture structure occurs in Diplodiscus paniculatus Turczaninow); possibly Bombacaceae. Somewhat similar to Fremontodendron (Bombacaceae or Sterculiaceae).

Occurrence.- "Infrequent" in 36/56 counted samples from the upper part of the Claiborne Group to the lower part of the Vicksburg Group.

\section{Genus RETICULATAEPOLLIS Krutzsch, 1959a}

Reticulataepollis reticlavata $n$. sp.

Plate 14, figures 23-26

Description.-Size 16-30 $\mu \mathrm{m}$, mean $23 \mu \mathrm{m}$, holotype $23 \mu \mathrm{m}$. Tricolporate. Oblate; outline rounded triangular. Exine $0.5 \mu \mathrm{m}$ thick; reticulate, the muri coarsely clavate in optical section, muri $0.5-1 \mu \mathrm{m}$ thick, clavae $1.5-2$ $\mu \mathrm{m}$ high, projecting slightly above muri; muri $1 \mu \mathrm{m}$ wide, lumina $1.5-2.5 \mu \mathrm{m}$ in diameter. Colpi boat shaped, $5.5 \mu \mathrm{m}$ long and $1 \mu \mathrm{m}$ wide; ora $1-1.5 \mu \mathrm{m}$ in diameter; endannulus $3-5.5 \mu \mathrm{m}$ in diameter.

Holotype._Plate 14, figures 23-24, slide 10558 A1 , coordinates $36.7 \times 118.8$, Gosport Sand at Little Stave Creek, Clarke County, Ala.

Remarks. - The specific epithet refers to the reticulate design (reticulum, Latin, "net") and the clavate optical section of the muri (clava, Latin, "club"). In Reticulataepollis intergranulata (Potonié, 1934) Krutzsch, 1959a (and its probable synonym Transdanubiaepollenites magnus Kedves and Párdutz, 1973), the surface of the lumina is granulate.

Affinity.-Kirkia (Simarubaceae) is similar but has very long colpi. Krutzsch (1959a, p. 243) suggested a similarity to Euphorbiaceae. Ligustrum ovalifolium Hassk. (Oleaceae; illustrated by Aubert and others, 1959, pl. 1, figs. 14-17) is also very similar.

Occurrence.- "Infrequent" in 10/56 counted samples from the upper part of the Claiborne Group and the Yazoo Clay.

\section{Reticulataepollis cf. R. intergranulata (Potonié) Krutzsch}

Reticulataepollis ef. $R$. intergranulatus (R. Potonie, 1934) Krutzsch, 1959a. Engelhardt, 1964a, p. 72, pl. 2, figs. 20, 24.

Remarks._Engelhardt's (1964a, pl. 2, figs. 20, 24) illustrated specimen from the upper part of the Cockfield
Formation at Jackson, Miss., is very similar to Reticulataepollis intergranulata, but it does not appear to have granulate lumina. I have not observed Engelhardt's species in my material.

\section{Genus SYMPLOCOS Jacquin}

Remarks.-Many species of Tertiary pollen grains have been assigned to the form genera Porocolpopollenites Pflug and Symplocoipollenites Potonié. The many studies now available on Holocene pollen grains have shown that no genera other than Symplocos have grains of the Porocolpopollenites-Symplocoipollenites type. Erdtman $(1952$, p. 425) already pointed out that the pollen type of Symplocos is unique. Therefore it seems justified to transfer a number of fossil pollen species to the modern genus. Most species previously assigned to the Proteaceae from the Upper Cretaceous and Tertiary of North America probably belong instead to the Symplocaceae (McLeroy, 1971, p. 96).

The following species are transferred to Symplocos: Symplocos austella (Partridge) n. comb.

Basionym.-Symplocoipollenites austellus Partridge in Stover and Partridge, 1973, p. 258, pl. 17, fig. 20. Symplocos calauensis (Krutzsch) n. comb.

Basionym._Porocolpopollenites calauensis Krutzsch, 1961 , p. 318, pl. 4, figs. 94-98.

Symplocos latiporis (Pflug and Thomson) n. comb.

Basionym.-Porocolpopollenites latiporis Pflug and Thomson in Thomson and Pflug, 1953, p. 93, pl. 10, figs. 123-124.

Symplocos microvestibulum (Krutzsch) n. comb.

Basionym.-Porocolpopollenites microvestibulum Krutzsch, 1961, p. 318, pl. 4, figs. 80-85.

Symplocos orbiformis (Pflug and Thomson) n. comb.

Basionym.-Porocolpopollenites orbiformis Pflug and Thomson in Thomson and Pflug, 1953, p. 94, pl. 11, figs. 24-26.

Symplocos schwarzbachii (Weyland and Takahashi) n. comb.

Basionym.-Porocolpopollenites schwarzbachi Weyland and Takahashi, 1961, p. 101, pl. 43, figs. 41-42. Symplocos triangula (Potonié) n. comb.

Basionym.-Pollenites triangulus Potonié, 1931a, p. 332 , pl. 2, fig. 9.

Symplocos vestibuloformis (Pflug) n. comb.

Basionym.-Porocolpopollenites vestibuloformis Pflug in Thomson and Pflug, 1953, p. 93, pl. 10, fig. 122.

Symplocos vestibulum (Potonié) n. comb.

Basionym.-Pollenites vestibulum Potonié, 1931a, p. 332, pl. 2, fig. 23.

Syniplocos arcuata n. sp.

Plate 15, figures $1-4$

Symplocoipollenites sp. Fairchild and Elsik, 1969, p. 84, pl. 37, fig. ?15. 
Description.-Size 26-30 $\mu \mathrm{m}$ (six specimens), mean $28 \mu \mathrm{m}$, holotype $26 \mu \mathrm{m}$. Oblate or peroblate; outline triangular with convex sides. Tricolporate, colpi extending about one-third the distance to poles, not bordered by thickenings; ora obscure in polar view; vestibulum slit shaped in optical section because both sexine and nexine are arched outward at the apertures. Exine $1 \mu \mathrm{m}$ thick excluding ornamentation, weakly tegillate, sexine:nexine ratio 1.5:1; at the apertures, sexine is about $1.3 \mu \mathrm{m}$ thick and nexine $1 \mu \mathrm{m}$; thickening of exine at apertures (tumescence) produces darker exine color in aperture region. Exine rugulate to verrucate, elements $0.5 \mu \mathrm{m}$ wide and $0.2-0.5 \mu \mathrm{m}$ high; no negative reticulum present.

Holotype.-Plate 15, figures 1-2, slide 10556 A-1, coordinates $31.5 \times 114.0$, Gosport Sand at Little Stave Creek, Clarke County, Ala.

Remarks.-Symplocos arcuata is characterized by having the nexine arched outward at the apertures (arcuatus, Latin, "bent like a bow") so that the vestibulum is a slitlike arc or thin crescent in optical section; in most other species of the genus, the nexine is flat or arched inward at the aperture so that the vestibulum is more or less lens shaped in optical section. Symplocos austella (Partridge) n. comb. is similar to $S$. arcuata but is finely granulate.

Occurrence.- "Infrequent" in three counted samples and present in one uncounted sample; it ranges from the upper part of the Claiborne Group to the lower part of the Vicksburg Group.

Symplocos ceciliensis (Thiergart) n. conib.

Plate 15, figure 5

Symplocos-pollenites vestibulum ceciliensis Thiergart in Potonie and others, 1950, p. 61, pl. C, fig. 35 (basionym).

Symplocoipollenites sp. Tschudy and Van Loenen, 1970, pl. 5, figs. ?10, ?12.

Remarks. Symplocos ceciliensis is granulate to verrucate, whereas Symplocos vestibulum vestibulum $(\mathrm{Po}-$ tonié) $n$. comb. is rather finely granulate. The two forms are different enough that they can be considered separate species.

Occurrence. - "Infrequent" in 13/56 counted samples from the upper part of the Claiborne Group to the lower part of the Vicksburg Group.

\section{Symplocos contracta n. sp.}

Plate 15, figures 6-9

Symplocoipollenites sp. 1. Engelhardt, 1964a, p. 75, pl. 4, fig. 39. Triporopollenites sp. Tschudy and Van Loenen, 1970, pl. 3, fig. 13. Porocolpopollenites spp. Tschudy, 1973, p. B15, pl. 3, figs. 5-6.

Description.-Size 22-34 $\mu \mathrm{m}$, mean $28 \mu \mathrm{m}$, holotype $32 \mu \mathrm{m}$. Peroblate; outline triangular with straight to slightly convex sides. Tricolporate. Exine finely foveolate and tegillate; midway between apertures it is $1.5-2$ $\mu \mathrm{m}$ thick. Nexine $0.5 \mu \mathrm{m}$, endosexine $0.7-1 \mu \mathrm{m}$, ectosexine $0.3-0.5 \mu \mathrm{m}$; sexine thins gradually toward apertures, where it is $0.5-1 \mu \mathrm{m}$ thick. Colpi $1-2.5 \mu \mathrm{m}$ long, lacking marginal thickenings; ora obscure; vestibula 0.5 $\mu \mathrm{m}$ or less deep, typically slitlike in optical section.

Holotype.-Plate 15, figures 6-7, slide 10556 A-1, coordinates $28.7 \times 120.4$, Gosport Sand at Little Stave Creek, Clarke County, Ala.

Remarks.-The specific epithet (contractus, Latin, "compressed, narrowed") refers to the thinning of the sexine toward the apertures. In Symplocos vestibulum (Potonié, 1931a) n. comb., S. triangula (Potonié, 1931a) n. comb., and $S$. novae-angliae Traverse, 1955 , the sexine does not thin toward the apertures; Symplocos jacksoniana Traverse, 1955, and S. scabripollinia Traverse, 1955 , have concave sides.

Occurrence.- "Infrequent" in 29/56 counted samples from the upper part of the Claiborne Group to the lower part of the Vicksburg Group.

\section{Syniplocos gemmata n. sp.}

Plate 15, figures 10-14

Symplocoipollenites sp. Tschudy and Van Loenen, 1970, pl. 5, figs. 6a-b.

Porocolpopollenites spp. Tschudy, 1973, p. B16, pl. 4, figs. 8-9.

Description.—Size 19-31 $\mu \mathrm{m}$, mean $26 \mu \mathrm{m}$, holotype $29 \mu \mathrm{m}$. Tricolporate. Oblate; outline triangular with strongly convex to nearly straight sides. Exine $1 \mu \mathrm{m}$ thick, sexine:nexine ratio 2:1 except at apertures. Sexine indistinctly tegillate and rather sparsely to densely gemmate to granulate, the elements typically varying in size on each specimen, from 0.3 to $1.5 \mu \mathrm{m}$ in diameter and to as much as $1 \mu \mathrm{m}$ in height. Ornamentation covers entire exine up to edge of apertures. Colpi $0.5-1 \mu \mathrm{m}$ wide at the equator, narrowing rapidly away from the equator; colpi very short, usually not extending beyond endannulus, often barely visible so that some grains look triporate; colpi may be bordered by narrow $(0.5-\mu \mathrm{m}$-wide), smooth margines which wrap around ends of colpi. Shallow vestibula present. Endannuli $2-3 \mu \mathrm{m}$ thick, with ora about $2.5 \mu \mathrm{m}$ in diameter; sexine does not thicken at apertures.

Holotype.-Plate 15, figure 10, slide 10653 A-1, coordinates $20.4 \times 125.3$, Yazoo Clay near Cynthia, Hinds County, Miss.

Remarks. Symplocos gemmata is distinguished by its convex sides and gemmate to granulate ornamentation. The specific epithet (gemmatus, Latin, "with buds") refers to the ornamentation. Symplocos latiporis (Pflug and Thomson) n. comb. has straight sides and is more finely gemmate. Symplocos calauensis (Krutzsch, 1961) n. comb. has a distinctly columellate sexine, and the design between the gemmae is distinctly punctate. 
Affinity.-Similar to modern pollen of Symplocos aneityensis de la Rue, illustrated by van der Meijden (1970, pl. 6, figs. 1-3).

Occurrence.- "Infrequent" in 13 counted samples from the upper part of the Claiborne Group to the top of the Yazoo Clay.

\section{Symplocos jacksoniana Traverse}

Plate 15, figures 15-16

Symplocos jacksoniana Traverse, 1955, p. 73, fig. 13 (128).

Symplocoipollenites jacksonius (Traverse) Potonié, 1960, p. 107.

Proteacidites sp. Engelhardt, 1964a, p. 75, pl. 4, fig. 41.

Symplocoipollenites sp. Tschudy and Van Loenen, 1970, pl. 5, fig. 9.

Remarks.-Thomson and Pflug (1953, p. 94, pl. 11, figs. 3-23) described and illustrated specimens that they attributed to Porocolpopollenites vestibulum (Potonié, 1931a) Thomson and Pflug, 1953 [ = Symplocos vestibulum (Potonié) n. comb. ] but that probably belong to Symplocos jacksoniana. The holotype of $S$. vestibulum is granulate (Potonié, 1931a, pl. 2, fig. 23; Potonié and others, 1951, p. 61; Potonié, 1960, p. 106-107), whereas $S$. jacksoniana and the specimens of Thomson and Pflug are reticulate-rugulate-foveolate.

Occurrence.- "Infrequent" in six counted samples from the Cockfield Formation and the Yazoo Clay.

\section{Symplocos tecta n. sp.}

Plate 15, figures $17-20$

Tricolporopollenites sp. 7. Engelhardt, 1964a, p. 74, pl. 3, fig. 32.

Description. - Size 26-34 $\mu \mathrm{m}$, mean $31 \mu \mathrm{m}$, holotype $34 \mu \mathrm{m}$. Oblate or peroblate; outline rounded triangular. Tricolporate; colpi extend one-third to one-half the distance to poles, not bordered by thickenings; vestibula shallow, often slitlike in optical section, sometimes covered by folds; ora obscure in polar view. Exine $3-4 \mu \mathrm{m}$ thick midway between apertures; tegillate, ectosexine:endosexine:nexine ratio about 2-4:1:1; sexine thins toward apertures. Exine infraverrucate to infrarugulate, elements $0.5-1 \mu \mathrm{m}$ wide; very fine negative reticulum present.

Holotype.-Plate 15, figures 17-18, slide $10663 \mathrm{~A}-$ 1 , coordinates $23.3 \times 112.8$, Moodys Branch Formation near Rose Hill, Jasper County, Miss.

Remarks. Symplocos tecta is characterized by its thick tegillate exine (tectus, Latin, "covered" = tegillate) and fine infrareticulum.

Affinity. - Similar to modern pollen of Symplocos glauca Pételot, illustrated by van der Meijden (1970, pl. 2, figs. 4-7).

Occurrence.-"Infrequent" in 9/56 counted samples from the upper part of the Claiborne Group to the lower part of the Vicksburg Group.
Symplocos? thalmannii (Anderson) n. comb.

Plate 15, figure 21

Proteacidites thalmanni Anderson, 1960, p. 21, pl. 2, figs. 1-4; pl. 10, figs. 9-13 (basionym).

Affinity.-Martin and Harris (1974, p. 111) pointed out that this species is brevicolporate and thus does not belong to Proteacidites. They also noted that Rouse $(1962$, p. 205) originally considered a similar or identical species, Proteacidites terrazus Rouse, 1962, to belong to Symplocos.

Occurrence.-These specimens may be reworked. The species has previously been reported from the uppermost Cretaceous but not from the Paleocene. On the other hand, it occurs in six Mississippi samples ranging from Cockfield to Forest Hill in age, and this distribution would be unusual if the grains were reworked. Hopkins (1967, pl. 4) observed the species in the upper Eocenemedial Oligocene sequence of Oregon. This species includes specimens of rather simple structure and ornamentation, and the grains may have been produced by different species or even genera of plants at various times during the Late Cretaceous and Tertiary.

\section{Symplocos sp. \\ Plate 15, figure 22}

Symplocoipollenites sp. 2. Engelhardt, 1964a, p. 75, pl. 4, fig. 40.

Description. - Size 30-31 $\mu \mathrm{m}$ (three specimens, including Engelhardt's illustrated specimen). This species is much like Symplocos contracta n. sp. except that it is punctate and faintly tegillate, whereas $S$. contracta is foveolate and more or less distinctly tegillate. Symplocos sp. may be synonymous with Symplocos schwarzbachii (Weyland and Takahashi) n. comb., although the latter is slightly larger $(40-44 \mu \mathrm{m})$ and is described as being "chegranat" (Weyland and Takahashi, 1961, p. 101); the illustration of the holotype suggests that the species is very finely granulate in design.

Occurrence.-Three specimens known from the Cockfield Formation and the Yazoo Clay of western Mississippi.

\section{Genus NUDOPOLLIS Pflug, 1953}

Nudopolis terminahis (Pflug and Thomson) Elsik

Plate 15 , figure 23

Extratriporopollenites terminalis Pflug and Thomson in Thu..1son and Pflug, 1953, p. 71, pl. 6, figs. 30-36.

Nudopollis terminalis (Pflug and Thomson, 1953) Elsik, 1968b, p. 648. Nudopollis spp. of the N. terminalis type. Tschudy, 1973, p. B14, pl. 2 , figs. $18-20$.

Nudopollis aff. N. terminalis (Thomson and Pflug) Pflug, 1953. Tschudy, 1975 , p. 16 , pl. 8 , figs. $16-25$. 
Remarks. -Pflug (1953, p. 161) is considered by most writers to be the author of the combination Nudopollis terminalis; however, according to the International Code of Botanical Nomenclature (Lanjouw and others, 1966, Art. 33), in combining the specific epithet with $\mathrm{Nudopol}$ lis, Pflug did not give "a full and direct reference $* * *$ to [the basionym's] author and original publication with page or plate reference and date." Thus, the combination was not valid in Pflug's paper.

Affinity.-Unknown.

Occurrence. - "Infrequent" in 15/56 counted samples from the upper part of the Claiborne Group to the top of zone I (nearly to the top of the Yazoo Clay). This species ranges down into the Paleocene of the gulf coast (Elsik, 1968 b, p. 650; Tschudy, 1975, p. 16). According to Tschudy $(1973,1975)$ and Elsik $(1974 b ;$ Elsik and Dilcher, 1974), Nudopollis terminalis does not range higher than the top of the Claiborne Group. However, these authors also pointed out that the species reaches its maximum relative frequencies in the upper part of the Claiborne; thus, it is not surprising that the species is now found to range well up into the Jackson.

\section{Genus TETRACOLPOROPOLLENITES Pflug and Thomson in} Thonison and Pflug, 1953

Remarks. - The synonymy of this genus was discussed by Potonié (1966, p. 172-173).

\section{Tetracolporopollenites brevis n. sp. \\ Plate 16, figures 1-3}

Sapotaceoidaepollenites sp. Tschudy and Van Loenen, 1970, pl. 5, figs. 4, 8a-b.

Description. -Size $24-42 \mu \mathrm{m}$, mean $32 \mu \mathrm{m}$, holotype $31 \mu \mathrm{m}$. Prolate spheroidal to prolate; sides straight to convex. Tetracolporate; colpi only one-half to two-thirds the length of grain, $0.5 \mu \mathrm{m}$ wide or less, sometimes bordered by narrow thickenings; ora distinct, lalongate, about 2-2.5 $\mu \mathrm{m} \times 5-6 \mu \mathrm{m}$. Exine 1.2-1.5 $\mu \mathrm{m}$ thick, nexine very thin; exine often slightly thicker in equatorial region, producing darkened equatorial band. Exine psilate to faintly punctate.

Holotype.-Plate 16, figure 1, slide 10675 A-1, coordinates $24.2 \times 120.0$, Yazoo Clay at Yazoo City, Miss.

Remarks. -Tetracolporopollenites brevis is distinguished by its short colpi (brevis, Latin, "short") and psilate or nearly psilate exine.

Affinity.-Sapotaceae, perhaps Bumelia.

Occurrence. - "Infrequent" in $8 / 56$ counted samples from the Moodys Branch Formation to the Forest Hill Sand in western and eastern Mississippi.

Tetracolporopollenites lesquereuxianus (Traverse) n. conb.

Plate 16, figure 4

Manilkara lesquereuxiana Traverse, 1955, p. 70, fig. 12 (120-121) (basionym).
Sapotaceoidaepollenites lesquereuxianus (Traverse) Potonié, 1960, p. 109.

Sapotaceoidaepollenites ef. S. manifestus (R. Potonié, 1931) Potonié, Thomson, and Thiergart, 1950. Engelhardt, 1964a, p. 76, pl. 4, fig. 49.

Sapotaceoidaepollenites sp. Tschudy and Van Loenen, 1970, pl. 5, figs. 7a-b.

Remarks. - Grains in this species are generally subprolate, psilate to punctate, and tetracolporate and have rather long colpi and distinct lalongate ora.

Affinity.-Sapotaceae, probably Manilkara at least in part.

Occurrence. - "Infrequent" to "occasional" in $37 / 56$ counted samples from the upper part of the Claiborne Group to the lower part of the Vicksburg Group.

Tetracolporopolienites negadolium (Potonié) n. conıb.

Plate 16, figure 5

Pollenites megadolium Potonié, 1931a, p. 332, pl. 1, figs. 16, 25 (basionym).

Sapotaceoidaepollenites megadolium (Potonié) Potonié, 1960, p. 109. Tricolporopollenites sp. 6. Engelhardt, 1964a, p. 74, pl. 3, fig. 31. Tricolporites sp. Tschudy and Van Loenen, 1970, pl. 5, fig. 5.

Remarks.-Potonié described this species and its intraspecific variations in detail (Potonié, 1934, p. 8889, pl. 4, figs. 32-34; pl. 5, figs. 2, 4, 5, 7, 9; Potonié and Venitz, 1934, p. 42 , pl. 4 , figs. 120 , 122). Specimens from the Jackson Group and adjacent strata show the full range of variation described by Potonié. However, he included three- and four-colporate specimens in the species, and the former predominated; I have included only three-colporate specimens in this species and have placed the four-colporate specimens of similar type in the species Tetracolporopollenites lesquereuxianus (Traverse, 1955) n. comb. Potonié (1934, p. 88) reported a size range of $40-80 \mu \mathrm{m}$ for $T$. megadolium from the Eocene, and he reported (in Potonié and Venitz, 1934, p. 42) a size range of $20-42 \mu \mathrm{m}$ for the species from the Miocene. Thus the size as well as the design and colpus-os relationships are quite variable in this species. My specimens were $27-54 \mu \mathrm{m}$, with a mean of only $35 \mu \mathrm{m}$; most specimens were between 29 and $36 \mu \mathrm{m}$. Pflug and Thomson (in Thomson and Pflug, 1953, p. 108) defined the genus Tetracolporopollenites to include both three- and fourcolporate forms, and Potonié (1960, p. 109) included Pollenites megadolium in his genus Sapotaceoidaepollenites, which is a synonym of Tetracolporopollenites.

Affinity.-Sapotaceae. Probably produced at least in part by the same plants as Tetracolporopollenites lesquereuxianus (Traverse, 1955) n. comb.

Occurrence.- "Infrequent" to "common" in 40/56 counted samples from the upper part of the Claiborne Group to the lower part of the Vicksburg Group. 
Tetracolporopollenites sp.

Plate 16, figure 6

Description.-Size $18 \times 21 \mu \mathrm{m}$ (one specimen); subprolate. Tetracolporate; colpi narrow, extending one-third the length of grain; ora lalongate, $1.5 \times 4 \mu \mathrm{m}$, covered by thin bulging layer of exine. Exine $0.3 \mu \mathrm{m}$ thick at poles, increasing to $0.5 \mu \mathrm{m}$ thick at equator, resulting in darkened equatorial band. Exine indistinctly tegillate; design granulate.

Remarks. - Tetracolporopollenites sp. is similar to the so-called Pollenites manifestus Potonié, 1931b, illustrated by Potonié, 1934 (p. 86-87, pl. 4, figs. 24-31; pl. 6, fig. 26). This Eocene species of Potonié (1934) is not the same as the Miocene holotype of Pollenites manifestus described in Potonié, 1931b, and redescribed by $\mathrm{Po}-$ tonié and Venitz (1934, p. 41, pl. 4, fig. 117). Potonié and Venitz pointed out that the Miocene form (that is, true Pollenites manifestus) has longer colpi than the Eocene specimens. Thus the Eocene Pollenites manifestus of Potonié (1934) should be a new species. My specimen has short colpi like Potonié's Eocene "Pollenites manifestus," and it is granulate like that species and like the true Pollenites manifestus. However, it is smaller, and it has a thinner exine and is subprolate, whereas Potonié's Eocene specimens are prolate. Tetracolporopollenites manifestus (Potonié) Thomson and Pflug, 1953 (p. 110 , pl. 15, figs. 35-43) is still another species, similar to Potonié's Eocene "Pollenites manifestus" but psilate. The specimen that Fairchild and Elsik (1969, p. 83, pl. 37, fig. 7) labeled Sapotaceae(?) is similar to Tetracolporopollenites sp. but is psilate.

Affinity. - Sapotaceae.

Occurrence.-One specimen observed from the Yazoo Clay of western Mississippi.

\section{Genus FOVEOSTEPHANOCOLPORITES Leidelmeyer, 1966}

Foveostephanocolporites bellus $\mathrm{n}$. $\mathbf{s p}$.

Plate 16, figures 7-12

Description.-Size 25-36 $\mu \mathrm{m}$ (four specimens), holotype $36 \mu \mathrm{m}$. Subprolate to prolate, with broadly rounded to flattened poles. Stephanocolporate $(12$ colpi), colpi extending nearly full length of grain, $1 \mu \mathrm{m}$ wide; some of the colpi may widen to $1.5-2 \mu \mathrm{m}$ wide at the ora; width of intercolpia at the equator $2-3 \mu \mathrm{m}$. Edges of colpi not modified. Zonorate, thinning of exine forming a pale band 4-6 $\mu \mathrm{m}$ wide at the equator. Exine at poles 0.5-1 $\mu \mathrm{m}$ thick, thickening toward the equator, exine at edge of orate band twice as thick as at the poles; orate band formed by an abrupt loss of the inner half of the exine. Exine stratification rather obscure, tegillum lacking or columellae only faintly present; at the poles, ectosexine:endosexine:nexine ratio is apparently 1:2:1; near the equator, sexine:nexine ratio is apparently $1: 1$, and nexine is lacking in the orate band. Thus, most of the thickening of the exine from the poles toward the equator is probably due to thickening of the nexine. Exine foveolate, the pits $0.5 \mu \mathrm{m}$ in diameter, two to three,irregular rows of them present down each intercolpial strip.

Holotype._Plate 16, figures 7-8, slide 10557 A-2, coordinates $25.0 \times 119.6$, Gosport Sand at Little Stave Creek, Clarke County, Ala.

Remarks. -The specific epithet bellus is Latin for "pretty." Foveostephanocolporites liracostatus Leidelmeyer, 1966, may be zonorate, but it has a circumequatorial bulge and is much larger.

\section{Affinity.-Perhaps Polygalaceae.}

Occurrence. - Known from the Gosport Sand at Little Stave Creek and the Cockfield Formation-Moodys Branch Formation transition zone and the lower part of the Yazoo Clay at Jackson, Miss.

\section{Genus ERICIPITES Wodehouse, 1933}

Ericipites aff. E. ericius (Potonié) Potonié

Plate 16, figures 13-14

Pollenites ericius Potonié, 1931a, p. 332, pl. 2, fig. 25. Ericipites ericius (Potonié) Potonié, 1960, p. 138.

Description. - Size of tetrad 25-36 $\mu \mathrm{m}$. Tetrad very compact, only slight indentations present in the overall outline where grains meet. Tricolporate; colpi one-half to two-thirds of the radius of individual grain; ora inconspicuous, round, $1 \mu \mathrm{m}$ or less in diameter. Colpi of adjacent grains meet at the junctures of the grains two by two (Fischer's rule). Exine 1-1.5 $\mu \mathrm{m}$ thick, ectosexine: endosexine:nexine ratio about 1:1.3:1; columellae apparently lacking or faintly visible; exine punctate.

Remarks. -Krutzsch (1970c, pl. 54, figs. 1-6 and 710) provided photomicrographs of the holotype and lectotype, respectively, of Ericipites ericius and $E$. callidus (Potonié, 1931a) Krutzsch, 1970c. The holotype of $E$. ericius may have a thicker exine than the Jackson-Vicksburg specimens, but it is also possible that folds are present in the holotype which make the exine appear thicker than it really is; specimens attributed to $E$. ericius by Sontag (1966, pl. 69, figs. 2-4) have exines that are only about 1-1.5 $\mu \mathrm{m}$ thick. The holotype of $E$. ericius has colpi that are slightly longer than one-half the radius of the individual grains, and the exine appears to be punctate. Colpi are not visible in the photomicrograph of the lectotype of $E$. callidus, but according to Krutzsch (1970c, p. 422), $E$. callidus and $E$. ericius may be synonyms of each other. The exine of the lectotype of $E$. callidus appears to be weakly granulate in design, but columellae are only faintly visible. The holotype of Ericipites acastus (Potonié, 1931b) Krutzsch, 1970c, appears to be sim- 
ilar in all respects to that of $E$. ericius. Sontag (1966, pl. 70, fig. 5) and Krutzsch (1970c, p. 422) interpreted $E$. acastus as including forms that have heavy folds along the junctures of the grains, but this is a characteristic of the specimen that Potonié (1931b, fig. 2) labelled Pollenites cf. acastus, and the holotype of $E$. acastus probably does not show this feature. In Ericipites longisulcatus Wodehouse, 1933, the colpi are probably rather broad, but otherwise the grains may be similar to the JacksonVicksburg specimens; however, the morphology of $E$. longisulcatus is poorly known. The ora in Ericipites compactipolliniatus (Traverse, 1955) Potonié, 1960, are narrow and lalongate.

\section{Affinity.-Probably Ericaceae.}

Occurrence. - "Infrequent" in 15/56 counted samples from the Moodys Branch Formation to the lower part of the Vicksburg Group; mostly in the upper part of the Yazoo Clay, Forest Hill Sand, and Red Bluff Clay.

\section{Ericipites redbluffensis n. sp.}

Plate 16, figures 15-18

Description.-Size of tetrad 27-32 $\mu \mathrm{m}$, mean $29 \mu \mathrm{m}$, holotype $29 \mu \mathrm{m}$. Distinct notches present in outline of tetrad where grains meet. Individual grains more or less spheroidal; outline of grain in polar view triangular with concave to convex sides. Tricolpate with definite geniculi and probably no ora, colpi extending nearly full length of grain or sometimes syncolpate. Colpi of adjacent grains probably meet fundamentally according to Fischer's rule, but because the grains are syncolpate or nearly so, colpi of all four grains of the tetrad meet at or nearly at the center of the tetrad. Exine $1 \mu \mathrm{m}$ thick, tegillate, ectosexine:endosexine:nexine ratio $1: 2: 1$; sharply infragranulate to finely infraverrucate; outline rough.

Holotype.-Plate 16, figure 15, slide $10529 \mathrm{~A}-1$, coordinates $28.5 \times 126.1$, Red Bluff Clay near Hiwannee, Wayne County, Miss.

Remarks.-Ericipites redbluffensis is characterized by its long, geniculate colpi and infragranulate to finely infraverrucate design. In Laxipollis laxa (Traverse, 1955) Krutzsch, 1970c, the colpi of each grain in polar view form a triangle; in Ericipites redbluffensis, the colpi of individual grains in polar view form a "trilete mark."

Affinity.-Ericaceae?

Occurrence.- "Infrequent" to "occasional" in $13 / 56$ counted samples from the upper part of the Claiborne Group to the lower part of the Vicksburg Group.

\section{REFERENCES CITED}

Ames, H. T., and Kremp, G. O. W., eds., 1964, Early and late Tertiary spores and pollen, v. 21 of Catalog of fossil spores and pollen: University Park, $\mathrm{Pa}$., Pennsylvania State Univ., $172 \mathrm{p}$.

Anderson, R. Y., 1960, Cretaceous-Tertiary palynology, eastern side of the San Juan basin, New Mexico: New Mexico Bur. Mines and Mineral Resources Mem. 6, 58 p., 11 pls.
Aubert, Jean, Charpin, Huguette, and Charpin, Jacques, 1959, Étude palynologique de quelques Oléacées de Provence: Pollen et Spores, v. 1, p. $7-13,1 \mathrm{pl}$.

Bandy, O. L., 1949, Eocene and Oligocene Foraminifera from Little Stave Creek, Clarke County, Alabama: Bulls. Am. Paleontology, v. 32 , no. 131,210 p.

Belsky, C. Y., Boltenhagen, E., and Potonié, R., 1965, Sporae dispersae der Oberen Kreide von Gabun, äquatoriales Afrika: Paläont. Zeitschr., v. 39, p. 72-83, pls. 12, 13.

Berggren, W. A., 1972, A Cenozoic time-scale-some implications for regional geology and paleobiogeography: Lethaia, v. 5, p. 195215,9 figs.

Berry, E. W., 1924, The middle and upper Eocene floras of southeastern North America: U. S. Geol. Survey Prof. Paper 92, 206 p., 9 figs., 65 pls.

Bicker, A. R., Jr., 1965, Hinds County structural geology, in Moore, W. H., Bicker, A. R., Jr., McCutcheon, T. E., and Parks, W. S., Hinds County geology and mineral resources: Mississippi Geol. Econ. and Topog. Survey Bull. 105, p. 147-156.

Blake, D. B., 1950, Gosport Eocene Ostracoda from Little Stave Creek, Alabama: Jour. Paleontology, v. 24, p. 174-184, pls. 2930.

Blanpied, B. W., and Hazzard, R. T., 1938, Correlation of Cockfield and Gosport formations, eastern Mississippi and western Alabama: Am. Assoc. Petroleum Geologists Bull., v. 22, p. 309-314.

Blow, W. H., 1969, Late middle Eocene to recent planktonic foraminiferal biostratigraphy, in Brönnimann, P., and Renz, H. H., eds., Proceedings of the First International Conference on Planktonic Microfossils, Geneva, 1967: Leiden, E. J. Brill, v. 1, p. 199-421, 43 figs., 54 pls.

Bolkhovitina, N. A., 1956, Atlas spor i pyltsy iz yurskikh i nizhnemelovykh otlozhennii Vilyuiskoi vpadiny [Atlas of spores and pollen from Jurassic and Lower Cretaceous deposits of the Vilyui depression]: Akad. Nauk SSSR Geol. Inst. Trudy, v. 2, 185 p., 25 pls.

-1961, Iskopaemye i sovremennye spory semeǐstva skhizeǐnykh [Fossil and modern spores of the Schizaea family]: Akad. Nauk SSSR Geol. Inst. Trudy, v. 40, 177 p., 41 pls.

Bramlette, M. N., and Wilcoxon, J. A., 1967, Middle Tertiary calcareous nannoplankton of the Cipero section, Trinidad, W. I.: Tulane Studies Geology, v. 5, p. 93-131.

Bybell, L. M., 1975, Middle Eocene calcareous nannofossils at Little Stave Creek, Alabama: Tulane Studies Geology and Paleontology, v. 11, p. 177-252.

Bybell, L. M., and Gartner, Stefan, 1972, Provincialism among midEocene calcareous nannofossils: Micropaleontology, v. 18, p. 319336,5 pls.

Chawner, W. D., 1936, Geology of Catahoula and Concordia Parishes: Louisiana Geol. Survey Geol. Bull. 9, 232 p.

-1952, Claiborne Bluff section, in Mississippi Geol. Soc., Claiborne of western Alabama and eastern Mississippi: Mississippi Geol. Soc., Ninth Field Trip, Jackson, Miss., Sept. 26-27, 1952, Guidebook, p. 60, 1 section.

Cheetham, A. H., 1957, Eocene-Oligocene boundary, eastern Gulf Coast region: Gulf Coast Assoc. Geol. Socs. Trans., v. 7, p. 8997.

1963, Late Eocene zoogeography of the eastern Gulf Coast region: Geol. Soc. America Mern. 91, 113 p.

Chmura, C. A., 1973, Upper Cretaceous (Campanian-Maastrichtian) angiosperm pollen from the western San Joaquin Valley, California, U.S.A.: Palaeontographica, v. 141, Abt. B, p. 89-171.

Cookson, I. C., 1947, Plant microfossils from the lignites of Kerguelen Archipelago: British, Australian and New Zealand [B.A.N.Z.] Antarctic Research Expedition, 1929-1931, Repts., Ser. A, v. 2, pt. 8, p. 127-142, pls. 13-17. 
1953, Difference in microspore composition of some samples from a bore at Comaum, South Australia: Australia Jour. Botany, v. 1 , p. $462-473$.

1957, On some Australian Tertiary spores and pollen grains that extend the geological and geographical distribution of living genera: Royal Soc. Victoria Proc., v. 69, p. 41-53.

Cookson, I. C., and Pike, K. M., 1954, Some dicotyledonous pollen types from Cainozoic deposits in the Australian region: Australian Jour. Botany, v. 2, p. 197-219, 2 pls.

Couper, R. A., 1953, Upper Mesozoic and Cainozoic spores and pollen grains from New Zealand: New Zealand Geol. Survey Paleont. Bull. 22, 77 p., 9 pls.

1960, New Zealand Mesozoic and Cainozoic plant microfossils: New Zealand Geol. Survey Paleont. Bull. 32, 87 p.

Cranwell, L. M., 1953, New Zealand pollen studies, the monocotyledons: Auckland Inst. and Museum Bull. 3, 91 p., 8 pls.

Davies, A. M., Eames, F. E., and Savage, R. J. G., 1975, Tertiary faunas. Vol. II, The sequence of Tertiary faunas: New York, Am. Elsevier Pub. Co., 447 p.

Deboo, P. B., 1965, Biostratigraphic correlation of the type Shubuta Member of the Yazoo Clay and Red Bluff Clay with their equivalents in southwestern Alabama: Alabama Geol. Survey Bull. 80, $84 \mathrm{p}$.

Dilcher, D. L., 1973, A revision of the Eocene flora of southeastern North America: Palaeobotanist, v. 20, p. 7-18.

Doktorowicz-Hrebnicka, Julia, 1960, Paralelizacja pokladów wíegla brunatnego województwa bydgoskiego i poznańskiego [Part of article translated as "Correlation of brown coal seams from the provinces of Poznań and Bydgoszcz"], in Doktorowicz-Hrebnicka, Julia, and Mamezar, Jadwiga, Stratygrafia srodkowego miocenu polski srodkowej na podstawie analizy sporowo-pylkowej wegla brunatnego $\mathrm{z}$ województwa bydgoskiego i poznańskiego [Stratigraphy of the middle Miocene in central Poland based on spore and pollen analysis of brown coal from the provinces of Bydgoszcz and Poznan]: [Poland] Inst. Geol. Bull. 157, p. 68-133, 30 pls. (English translation, p. 223-243).

Elsik, W. C., 1968a, Palynology of a Paleocene Rockdale lignite, Milam County, Texas. I. Morphology and taxonomy: Pollen et Spores, v. 10, p. 263-314, pls. 1-15.

1968b, Palynology of a Paleocene Rockdale lignite, Milam County, Texas. II. Morphology and taxonomy (end): Pollen et Spores, v. 10 , p. $599-664$, pls. $16-44$.

1974a, Nothofagus in North America: Pollen et Spores, v. 16, p. 285-299, 3 pls.

1974b, Characteristic Eocene palynomorphs in the Gulf Coast, U.S.A.: Palaeontographica, v. 149, Abt. B, p. 90-111, 4 pls.

Elsik, W. C., and Dilcher, D. L., 1974, Palynology and age of clays exposed in Lawrence clay pit, Henry County, Tennessee: Palaeontographica, v. 146 , Abt. B, p. $65-87$, pls. $27-31$.

Engelhardt, D. W., 1964a, Plant microfossils from the Eocene Cockfield Formation, Hinds County, Mississippi: Mississippi Geol. Econ. and Topog. Survey Bull. 104, p. 65-96, 5 pls.

-1964 b, A new species of Gothanipollis Krutzsch from the Cockfield Formation (middle Eocene) of Mississippi: Pollen et Spores, v. 6, p. $597-600,1 \mathrm{pl}$.

Erdtman, Gunnar, 1952, Pollen morphology and plant taxonomy. Angiosperms (An introduction to palynology. I): Waltham, Mass., Chronica Botanica Co., 539 p., 261 figs.

_-1954, On the occurrence of olacaceous pollen grains in Eocene deposits in Germany: Svensk Bot. Tidskr., v. 48, no. 4, p. 804805.

1957, Pollen and spore morphology/plant taxonomy. Gymnospermae, Pteridophyta, Bryophyta (An introduction to palynology. II): New York, The Ronald Press Co., 151 p., 265 figs., 5 pls.
Fairchild, W. W., and Elsik, W. C., 1969, Characteristic palynomorphs of the Lower Tertiary in the Gulf Coast: Palaeontographica, v. 128 , Abt. B, p. 81-89, pls. 37-38.

Fisher, W. L., 1964, Sedimentary patterns in Eocene cyclic deposits, northern Gulf Coast region: Kansas Geol. Survey Bull. 169, p. 151-170.

Fowler, Keith, 1971, A new species of Aglaoreidia Erdtm. from the Eocene of southern England: Pollen et Spores, v. 13, p. 135-147, $1 \mathrm{pl}$.

Frederiksen, N. O., 1969, Stratigraphy and palynology of the Jackson Stage (upper Eocene) and adjacent strata of Mississippi and western Alabama: Madison, Wis., Univ. Wisconsin, unpub. Ph.D. dissert., $355 \mathrm{p}$.

-1973, New mid-Tertiary spores and pollen grains from Mississippi and Alabama: Tulane Studies Geology and Paleontology, v. 10 , p. $65-86,3$ pls.

Gardner, Julia, 1957, Little Stave Creek, Alabama-paleoecologic study, in Treatise on marine ecology and paleoecology: Geol. Soc. America Mem. 67, v. 2, p. 573-587.

Gartner, Stefan, Jr., 1971, Calcareous nannofossils from the JOIDES Blake Plateau cores, and revision of Paleogene nannofossil zonation: Tulane Studies Geology and Paleontology, v. 8, p. 101-121, 5 figs., 5 pls.

Gartner, Stefan, Jr., and Smith, L. A., 1967, Coccoliths and related calcareous nannofossils from the Yazoo Formation (Jackson, late Eocene) of Louisiana: Kansas Univ. Paleont. Contr.-Paper 20, 7 p., 12 pls.

Geological Society of America, Southeastern Section, 1964, Trip 1Jackson-Vicksburg type sections, in Geological Society of America Guidebook for field trips, 1964 ann. mtg., Baton Rouge, La., April 9-12, 1964: P. 1-12.

Graham, Alan, ed., 1972, Floristics and paleofloristics of Asia and eastern North America: New York, Elsevier Pub. Co., 278 p.

Graham, Alan, and Jarzen, D. M., 1969, Studies in neotropical paleobotany. I. The Oligocene communities of Puerto Rico: Missouri Bot. Garden Annals, v. 56, p. 308-357, 89 figs.

Gray, Jane, 1960, Temperate pollen genera in the Eocene (Claiborne) flora, Alabama: Science, v. 132 , no. 3430 , p. $808-810,1$ fig., 1 table.

Hammen, Thomas van der, and Wijmstra, T. A., 1964, A palynological study on the Tertiary and Upper Cretaceous of British Guiana: Leidse Geol. Meded., v. 30, p. 183-241.

Harris, W. K., 1965, Basal Tertiary microfloras from the Princetown area, Victoria, Australia: Palaeontographica, v. 115, Abt. B, p. 75-106, pls. 24-29.

Hazel, J. E., 1970, Binary coefficients and clustering in biostratigraphy: Geol. Soc. America Bull., v. 81, p. 3237-3252.

Hendy, W. J., Jr., 1948, Notes on the stratigraphy of northeastern Wayne County, Mississippi, in Mississippi Geol. Soc., Upper Eocene, Oligocene, and lower Miocene of central Mississippi: Mississippi Geol. Soc., Sixth Field Trip [Jackson, Miss.], June 18-20, 1948, Guidebook: p. 25-31.

Hopkins, W. S., Jr., 1967, Palynology and its paleoecological application in the Coos Bay area, Oregon: Ore Bin, v. 29, no. 9, p. 161183,5 pls.

Horstman, Elwood, and Gardner, W. E., 1960, Introduction to first day's trip and Road log-first day, in Mississippi Geol. Soc., The Cenozoic of southeastern Mississippi and southwestern Alabama: Mississippi Geol. Soc., 15th Field Trip, Jackson, Miss., May 12 14, 1960, p. 7-10 and p. 11-17.

Howe, R. C., and Howe, H. J., 1971, Stratigraphic and paleoecologic significance of ostracods from Shubuta Clay (Tertiary) of Mississippi [abs.]: Am. Assoc. Petroleum Geologists Bull., v. 55, p. 344. 1973, Ostracodes from the Shubuta Clay (Tertiary) of Mississippi: Jour. Paleontology, v. 47, p. 629-656. 
Huddlestun, P. F., 1966, Facies change within upper Eocene-basal Oligocene deposits in Alabama, in Copeland, C. W., ed., Facies changes in the Alabama Tertiary-Guidebook for the fourth annual field trip, Dec. 1966: University, Ala., Alabama Geol. Soc., p. 4142.

Huff, W. J., 1970, The Jackson Eocene Ostracoda of Mississippi: Mississippi Geol. Econ. and Topog. Survey Bull. 114, 289 p., 20 figs., 27 pls.

Hughes, N. F., 1963, The assignment of species of fossils to genera: Taxon, v. 12 , p. 336-337.

Ibrahim, A. C., 1933, Sporenformen des Aegirhorizonts des Ruhr-Reviers: Wurzburg, Dissertationsdruckerei $\mathrm{K}$. Triltsch, $46 \mathrm{p}$.

Ivey, J. B., 1957, Geology and ground water in the Monroeville area, Alabama: Alabama Geol. Survey Bull. 66, 116 p.

Jansonius, Jan, and Hills, L. V., 1976, Genera file of fossil spores and pollen: Calgary, Calgary Univ. Dept. Geology, Spec. Pub., 3,431 cards.

Kedves, Miklos, 1960, Etudes palynologiques dans le bassin de Dorog, I: Pollen et Spores, v. 2, p. 89-118.

1961, Études palynologiques dans le bassin de Dorog, II: Pollen et Spores, v. 3, p. 101-153, 10 pls.

1969, Palynological studies on Hungarian early Tertiary deposits. English translation by B. Balkay: Budapest, Akadémiai Kiadó, 84 p., 22 pls.

Kedves, Miklos, and Párdutz, Á., 1973, Ultrastructure investigations of angiospermatophyte pollens from the lower Eocene: Acta Botanica, v. 18, p. 135-154, 9 pls.

Kremp, G. O. W., 1949, Pollenanalytische Untersuchung des miozänen Braunkohlenlagers von Konin an der Warthe: Palaeontographica, v. 90, Abt. B, p. 53-93.

1967, Tetrad markings of pteridophytic spores and their evolutionary significance: Rev. Palaeobotany and Palynology, v. 3, p. 311-323, 6 figs., 1 pl.

Kremp, G. O. W., Ames, H. T., and Kovar, A. J., eds., 1960, Jurassic and Cretaceous spores and pollen, v. 10 of Catalog of fossil spores and pollen: University Park, Pennsylvania State Univ., $180 \mathrm{p}$.

Krutzsch, Wilfried, 1959a, Mikropaläontologische (sporenpaläontologische) Untersuchungen in der Braunkohle des Geiseltales: Geologie Beihefte, no. 21-22, 425 p., 49 pls.

$1959 \mathrm{~b}$, Einige neue Formgattungen und -arten von Sporen and Pollen aus der mitteleuropäischen Oberkreide und dem Tertiär: Palaeontographica, v. 105, Abt. B, p. 125-157, pls. 31-35.

1960, Ueber Thomsonipollis magnificus (Th. \& Pf. 1953) n. fgen. n. comb. und Bemerkungen zur regionalen Verbreitung einiger Pollengruppen im älteren Paläogen: Freiberger Forschungshefte, no. C 86, p. 54-65, 5 pls.

1961, Beitrag zur Sporenpaläontologie der präoberoligozänen kontinentalen und marinen Tertiärablagerungen Brandenburgs: Geol. Gesell. DDR Ber., v. 5, p. 290-343, 5 pls.

1962, Stratigraphisch bzw. botanisch wichtige neue Sporen-und Pollenformen aus dem deutschen Tertiär: Geologie, v. 11, no. 3, p. 265-306, 10 pls.

1963, Die Sporen der Anthocerotacea und der Lycopodiaceae, Lf. II of Atlas der mittel- und jungtertiären dispersen Sporen- und Pollen- sowie der Mikroplanktonformen des nördlichen Mitteleuropas: Berlin, VEB Deutscher Verlag der Wissenschaften, 141 p., 50 figs., 50 pls.

1966, Zur Kenntnis der präquartären periporaten Pollenformen: Geologie Beihefte, v. 15, no. 55, p. 16-71.

$1970 \mathrm{a}$, Monoporate, monocolpate, longicolpate, dicolpate und ephedroide (polyplicate) Pollenformen, Lf. VII of Atlas der mittelund jungtertiären dispersen Sporen- und Pollen- sowie der Mikroplanktonformen des nördlichen Mitteleuropas: Jena, VEB Gustav Fischer Verlag, 175 p. 1970b, Einige neue Pollenformen aus den Familien der Tiliaceen, Bombacaceen und Sterculiaceen aus dem mitteleuropäischen Alttertiär: Jahrb. Geologie, v. 3 (1967), p. 275-307, 2 figs., 7 pls.

1970c, Zur Kenntnis fossiler dispersen Tetradenpollen: Paläontologische Abh., v. 3, Abt. B, p. 399-434.

1971, Coniferenpollen (Saccites und "Inaperturates"), Lf. VI of Atlas der mittel- und jungtertiären dispersen Sporen- und Pollensowie der Mikroplanktonformen des nördlichen Mitteleuropas: Jena, VEB Gustav Fischer Verlag, $234 \mathrm{p}$.

Krutzsch, Wilfried, Sontag, Erika, and Pacltová, Blanka, 1963, Sphagnaceoide und selaginellaceoide Sporenformen, Lf. III of Atlas der mittel- und jungtertiären dispersen Sporen- und Pollen- sowie der Mikroplanktonformen des nördlichen Mitteleuropas: Berlin, VEB Deutscher Verlag der Wissenschaften, 128 p., 19 figs., 43 pls.

Kuprianova, L. A., 1965, Palinologia serezhkotsvetnykh [The palynology of the Amentiferae]: Akad. Nauk SSSR, Komarov Bot. Inst., 214 p., 48 pls.

1966, A tentative code of the ancient and derivative characters of pollen grains of angiosperms: Palaeobotanist, v. 15, p. 35-37, 2 pls.

Lanjouw, J., and others, eds., 1966, International code of botanical nomenclature adopted by the Tenth International Botanical Congress, Edinburgh, August, 1964: Utrecht, Netherlands, Internat. Assoc. Plant Taxonomy, 402 p. (In English, French, and German.)

Leffingwell, H. A., 1971, Palynology of the Lance (Late Cretaceous) and Fort Union (Paleocene) formations of the type Lance area, Wyoming, in Kosanke, R. M., and Cross, A. T., eds., Symposium on palynology of the Late Cretaceous and Early Tertiary: Geol. Soc. America Spec. Paper 127, p. 1-64.

Leidelmeyer, P., 1966, The Paleocene and lower Eocene pollen flora of Guyana: Leidse Geol. Meded., v. 38, p. 49-70, 5 pls.

Levin, H. L., and Joerger, A. P., 1967, Calcareous nannoplankton from the Tertiary of Alabama: Micropaleontology, v. 13, p. 163-182, 4 pls.

Luper, E. E., Angurarohita, Rung, and Baughman, W. T., 1972, Smith County geology and mineral resources: Mississippi Geol. Econ. and Topog. Survey Bull. 116, 189 p.

Machin, Jane, 1971, Plant microfossils from Tertiary deposits of the Isle of Wight: New Phytologist, v. 70, p. 851-872, 2 pls.

MacNeil, F. S., 1944, Oligocene stratigraphy of southeastern United States: Am. Assoc. Petroleum Geologists Bull., v. 28, p. 13131354,1 fig.

1946, The Tertiary formations of Alabama, in Southeastern Geological Society, 4th Field Trip [southeastern Alabama], Sept. 27-29, 1946, Guidebook: p. 1-64.

1966, Middle Tertiary sedimentary regimen of Gulf Coastal region: Am. Assoc. Petroleum Geologists Bull., v. 50, p. 2344-2365.

Maher, L. J., Jr., 1972, Nomograms for computing 0.95 confidence limits of pollen data: Rev. Palaeobotany and Palynology, v. 13, p. 85-93, 6 figs.

Mai, D. H., 1961, Ueber eine fossile Tiliaceen-Blüte und tilioiden Pollen aus dem deutschen Tertiär: Geologie, no. 32, p. 54-93, 3 figs., pls. 9-12.

Mamczar, Jadwiga, 1960, Standard section of the middle Miocene for central Poland, in Doktorowicz-Hrebnicka, Julia, and Mamczar, Jadwiga, Stratygrafia środkowego miocenu polski środkowej na podstawie analizy sporowo-pylkowej wegla brunatnego $\mathrm{z}$ województwa bydgoskiego i poznańskiego. [Stratigraphy of the middle Miocene in central Poland based on pore and pollen analysis of brown coal from the provinces of Bydgoszez and Poznañ]: [Poland] Inst. Geol. Bull. 157, p. 193-222, 14 pls.

Manum, Svein, 1960, On the genus Pityosporites Seward 1914: Nytt Magasin for Botanikk, v. 8, p. 11-15, 1 pl. 
1962, Studies in the Tertiary flora of Spitsbergen, with notes on Tertiary floras of Ellesmere Island, Greenland, and Iceland, a palynological investigation: Norsk Polarinst. Skr. 125, 127 p., 26 figs., 21 pls.

Martin, A. R. H., and Harris, W. K., 1974, Reappraisal of some palynomorphs of supposed proteaceous affinity: Grana, v. 14, p. 108113.

Martin, H. A., and Rouse, G. E., 1966, Palynology of Late Tertiary sediments from Queen Charlotte Islands, British Columbia: Canadian Jour. Botany, v. 44, p. 171-208, 12 pls.

Martini, Erlend, 1969, Nannoplankton aus dem Latdorf (locus typicus) und weltweite Parallelisierungen im oberen Eozän und unteren Oligozän: Senckenbergiana Lethaea, v. 50, p. 117-159, 4 figs., 4 pls.

1971, Standard Tertiary and Quaternary calcareous nannoplankton zonation, in Farinacci, Anna, and Matteuci, R., eds., Proceedings of the II Planktonic Conference, Roma, 1970: Rome, Edizioni Tecnoscienza, v. 2, p. 739-785.

Mathur, Y. K., 1966, On the microflora in the Supra-trappeans of Western Kutch, India: Geol., Mining and Metall. Soc. India Quart. Jour., v. 38, p. 33-51, 2 pls.

May, J. H., 1974, Wayne County geology, in May, J. H., and others, eds., Wayne County geology and mineral resources: Mississippi Geol. Econ. and Topog. Survey Bull. 117, p. 13-194.

McLeroy, C. A., 1971, Late Cretaceous angiosperm pollen from the western San Joaquin Valley, California [abs.]: Geoscience and Man, v. 3, p. 95-96.

Meijden, R., van der, 1970, A survey of the pollenmorphology of the Indo-Pacific species of Symplocos (Symplocaceae): Pollen et Spores, v. 12 , p. $513-551,7$ pls.

Mellen, F. F., 1940, Geology, in Mellen, F. F., and MeCutchen, T. E., Yazoo County mineral resources: Mississippi Geol. Survey Bull. 39 , p. 9-72.

Meyer, B. L., 1956, Mikrofloristische Untersuchungen an jungtertiären Braunkohlen im östlichen Bayern: Geologica Bavarica, no. 25, p. $100-127,5 \mathrm{pls}$.

Mississippi Geological Society, 1948 [Road logs], in Mississippi Geol. Soc., Upper Eocene, Oligocene, and lower Miocene of central Mississippi: Mississippi Geol. Soc., Sixth Field Trip, [Jackson, Miss.], June 18-20, 1948, Guidebook: p. 22-24 and 31-36.

Monroe, W. H., 1954, Geology of the Jackson area, Mississippi: U. S. Geol. Survey Bull. 986, 133 p., 11 figs., 6 pls.

Monsour, E. T., 1948, Generalized stratigraphic discussion of postClaiborne sediments in Mississippi and correlation with equivalent age sediments in the Gulf Coast province, in Mississippi Geol. Soc., Upper Eocene, Oligocene, and lower Miocene of central Mississippi: Mississippi Geol. Soc., Sixth Field Trip, [Jackson, Miss.], June 18-20, 1948, Guidebook: p. 3-16.

Moore, W. H., 1965, Hinds County geology: Mississippi Geol. Econ. and Topog. Survey Bull. 105, p. 21-172.

Moore, W. H., Parks, W. S., and Kern, M. K., 1964, Type localities sampling program: Mississippi Geol. Econ. and Topog. Survey Bull. 104, p. 7-32.

Mosimann, J. E., 1965, Statistical methods for the pollen analystmultinomial and negative multinomial techniques, in Kummel, Bernhard, and Raup, David, eds., Handbook of paleontological techniques: San Francisco, W. H. Freeman and Co., p. 636-673.

Muller, Jan, 1968, Palynology of the Pedawan and Plateau Sandstone formations (Cretaceous-Eocene) in Sarawak, Malaysia: Micropaleontology, v. 14, p. 1-37.

-1970, Palynological evidence on early differentiation of angiosperms: Cambridge Philos. Soc. Biol. Rev., v. 45, p. 417-450, 6 figs.

Murray, G. E., 1961, Geology of the Atlantic and Gulf Coastal province of North America: New York, Harper \& Bros., 692 p.
Mürriger, Friedrich, and Pflanzl, Günter, 1955, Pollenanalytische Datierungen einiger hessischer Braunkohlen: Hesse Landesamt Bodenforschung Notizbl., v. 83, p. 71-89, pls. 5-6.

Nagy, Eszter, 1963a, Spores nouvelles des couches neógenès de Hongrie: Pollen et Spores, v. 5, p. 143-148, 2 pls.

$-1963 \mathrm{~b}$, Occurrence of the genus Ephedripites in the Neogene of Hungary: Grana Palynologica, v. 4, p. 277-280c, 12 figs.

Nakoman, E., 1965, Description d'un nouveau genre de forme, Corsinipollenites: Soc. Géol. Nord Annales, v. 85, p. 155-158, 2 figs., pl. 13.

Nayar, B. K., and Lata, Pushpa, 1965, Spore morphology of some African fern-allies: Pollen et Spores, v. 7, p. 313-318, 13 figs.

Nayar, B. K., Lata, P., and Tiwari, L. P., 1964, Spore morphology of the ferns of west tropical Africa: Pollen et Spores, v. 6, p. 545582,4 pls.

Nichols, D. J., 1973, North American and European species of Momipites ("Engelhardtia") and related genera: Geoscience and Man, v. 7, p. 103-117.

Nichols, D. H., Ames, H. T., and Traverse, Alfred, 1973, On Arecipites Wodehouse, Monocolpopollenites Thomson \& Pflug, and the species "Monocolpopollenites tranquillus": Taxon, v. 22, p. 241256, 2 pls.

Parks, W. S., 1965, Hinds County mineral industries, in Moore, W. H., Bicker, A. R., Jr., McCutcheon, T. E., and Parks, W. S., Hinds County geology and mineral resources: Mississippi Geol. Econ. and Topog. Survey Bull. 105, p. 215-243.

Penny, J. S., 1969, Late Cretaceous and early Tertiary palynology, in Tschudy, R. H., and Scott, R. A., eds., Aspects of palynology: New York, Wiley-Interscience, p. 331-376.

Pflanzl, Günter, 1956, Das Alter der Braunkohlen des Meissners, der Flöze 2 und 3 des Hirschberges und eines benachbarten Kohlenlagers bei Laudenbach: Hesse Landesamt Bodenforschung Notizbl., v. 84 , p. 232-244, pls. 16-17.

Pflug, H. D., 1953, Zur Entstehung und Entwicklung des angiospermiden Pollens in der Erdgeschichte: Palaeontographica, v. 95, Abt. B, p. 60-171, pls. 15-25.

Piel, K. M., 1971, Palynology of Oligocene sediments from central British Columbia: Canadian Jour. Botany, v. 49, no. 11, p. 18851920,17 pls.

Pierce, R. L., 1961, Lower Upper Cretaceous plant microfossils from Minnesota: Minnesota Geol. Survey Bull. 42, 86 p.

Planchais, Nadine, 1964, Le pollen de quelques Papilionacees méditerranéennes et subméditerranéennes: Pollen et Spores, v. 6, p. 515$526,4 \mathrm{pls}$.

Potonié, Robert, 1931a, Zur Mikroskopie der Braunkohlen. Tertiäre Blütenstaubformen: Braunkohle, v. 30, no. 16, p. 325-333, 2 pls.

1931b, Pollenformen aus tertiären Braunkohlen: Preuss. Geol. Landesanstalt Jahrb., v. 52, p. 1-7, 34 figs.

1931c, Zur Mikroskopie der Braunkohlen. Tertiäre Sporen- und Blütenstaubformen: Braunkohle, v. 30, no. 27, p. 554-556, 16 figs. 1932, Pollenformen der miocänen Braunkohle: Gesell. Naturforsch. Freunde Berlin Sitzungsber., Jahrg. 1931, no. 1-3, p. 2428, 2 pls. (separate issued 1931).

1934, Zur Mikrobotanik des eocänen Humodils des Geiseltals: Preuss. Geol. Landesanstalt, Inst. Paläobotanik und Petrographie Brennsteine Arb., v. 4, p. 25-117, 2 figs., 6 pls.

1951, Revision stratigraphisch wichtiger Sporomorphen des mitteleuropäischen Tertiärs: Palaeontographica, v. 91, Abt. B, p. 131-151, pls. 20-21.

1956, Synopsis der Gattungen der Sporae dispersae. I. TeilSporites: Geol. Jahrb. Beihefte 23, 103 p., 11 pls.

1958, Synopsis der Gattungen der Sporae dispersae. II. TeilSporites (Nachträge), Saccites, Aletes, Praecolpates, Polyplicates, Monocolpates: Geol. Jahrb. Beihefte 31, 114 p., 11 pls. 
-1960 , Synopsis der Gattungen der Sporae dispersae. III. TeilNachträge, Sporites, Fortsetzung Pollenites mit Generalregister zu Teil I-III: Geol. Jahrb. Beihefte 39, 189 p., 9 pls.

1966, Synopsis der Gattungen der Sporae dispersae. IV. TeilNachträge zu allen Gruppen (Turmae): Geol. Jahrb. Beihefte 72, $244 \mathrm{p}$.

-1970, Synopsis der Gattungen der Sporae dispersae. V. TeilNachträge zu allen Gruppen (Turmae): Geol. Jahrb. Beihefte 87, 222 p., 24 pls.

Potonié, Robert, and Gelletich, Johann, 1933, Ueber PteridophytenSporen einer eocänen Braunkohle aus Dorog in Ungarn: Gesell. Naturforsch. Freunde Berlin Sitzungsber., Jahrg. 1932, p. 517528,2 pls.

Potonié, Robert, and Klaus, Wilhelm, 1954, Einige Sporengattungen des alpinen Salzgebirges: Geol. Jahrb., v. 68, p. 517-546, pl. 10.

Potonié, Robert, and Kremp, Gerhard, 1954, Die Gattungen der paläozoischen Sporae dispersae und ihre Stratigraphie: Geol. Jahrb., v. 69, p. 111-194, 17 pls.

Potonié, Robert, and Venitz, Herbert, 1934, Zur Mikrobotanik des miocänen Humodils der niederrheinischen Bucht: Preuss. Geol. Landesanstalt, Inst. Paläobotanik und Petrographie Brennsteine Arb., v. 5, p. 5-54, 5 pls.

Potonié, Robert, Thomson, P. W., and Thiergart, Friedrich, 1951, Zur Nomenklatur and Klassifikation der neogenen Sporomorphae (Pollen und Sporen): Geol. Jahrb., v. 65 (1949), p. 35-70, 1 fig., 3 pls. (separate issued 1950).

Priddy, R. R., 1960, Madison County geology: Mississippi Geol. Survey Bull. 88, 123 p., 38 figs., 6 pls.

Raatz, G. V., 1937, Mikrobotanisch-stratigraphische Untersuchung der Braunkohle des Muskauer Bogens: Preuss. Geol. Landesanstalt Abh. 183, 48 p., 5 figs., 1 pl.

Rainwater, E. H., 1960, Stratigraphy and its role in the future exploration for oil and gas in the Gulf Coast: Gulf Coast Assoc. Geol. Socs. Trans., v. 10, p. 33-75, 33 figs.

1964, Transgressions and regressions in the Gulf Coast Tertiary: Gulf Coast Assoc. Geol. Socs. Trans., v. 14, p. 217-230, 16 figs.

Ross, N.-E., 1949, On a Cretaceous pollen and spore bearing clay deposit of Scania: Uppsala Univ. Geol. Inst. Bull., v. 34 (1949-1953), p. 25-43, 4 figs., 3 pls.

Roth, P. H., 1968, Calcareous nannoplankton zonation of Oligocene sections in Alabama (U.S.A.), on the islands of Trinidad and Barbados (W.I.), and the Blake Plateau (E. coast of Florida, U.S.A.): Eclogae Geol. Helvetiae, v. 61, p. 459-465, 3 figs., 1 pl.

-1970, Oligocene calcareous nannoplankton biostratigraphy: Eclogae Geol. Helvetiae, v. 63, p. 799-881, 17 figs., 14 pls.

Rouse, G. E., 1962, Plant microfossils from the Burrard Formation of western British Columbia: Micropaleontology, v. 8, p. 187-218, 5 pls.

Rudolph, Karl, 1935, Mikrofloristische Untersuchung tertiärer Ablagerungen im nördlichen Böhmen: Bot. Centralbl. Beihefte, Abt. B, v. 54, p. $244-327,5$ pls.

Sah, S. C. D., 1967, Palynology of an upper Neogene profile from Rusizi Valley (Burundi): Musée Royal Afrique Centrale Annales, Sér. in- $8^{\circ}$, Sci. Géol., no. 57, 173 p., 54 figs., 13 pls.

Scull, B. J., Felix, C. J., McCalab, S. B., and Shaw, W. G., 1966, The inter-discipline approach to paleoenvironmental interpretations: Gulf Coast Assoc. Geol. Socs. Trans., v. 16, p. 81-117, 17 figs., 9 pls.

Sein, M. K., 1961, Nothofagus pollen in the London Clay: Nature, v. 190 , p. $1030-1031$.

Seward, A. C., 1914, Antarctic fossil plants: Brit. Antarctic ("Terra Nova") Exped., 1910, Nat. History Rept., Geology, v. 1, no. 1, p. $1-49$, figs. $1-6$, maps A-C, pls. $1-8$.
Shakhmundes, V. A., 1965, Novye vidy Ephedra L. iz osadkov paleogena severa Zapadnoi Sibiri [New species of Ephedra L. from Paleogene sediments of northern Western Siberia]: Vses. Neft. Nauchno-Issled. Geol.-Razved. Inst. Trudy, v. 239, p. 214-228, 10 figs.

Simpson, J. B., 1961, The Tertiary pollen-flora of Mull and Ardnamurchan: Royal Soc. Edinburgh Trans., v. 64, no. 16, p. 421-468, 20 pls.

Skarby, Annie, 1964, Revision of Gleicheniidites senonicus Ross: Stockholm Contr. Geology, v. 11, p. 59-77, 1 fig., 3 pls.

1968, Extratriporopollenites (Pflug) emend. from the Upper Cretaceous of Scania, Sweden: Stockholm Contr. Geology, v. 16, p. 1-60, 12 figs., 30 pls.

Smith, R. H., and others, 1944, Little Stave Creek, Clarke County, Alabama, plan and geological cross section [and stratigraphic section], in Southwestern Alabama-The first field trip of the Southeastern Geological Society, June 21, 22, 23, 1944: [Tallahassee, Fla.], 2 sheets.

Society of Economic Paleontologists and Mineralogists, Gulf Coast Section, 1960, Type localities project, unit I, ed. by H. V. Andersen: Baton Rouge, La., [56 p.]

-1963 , Type localities project, unit III, ed. by H. V. Andersen: Baton Rouge, La., [47 p.]

-1967, Selected Cretaceous and. Tertiary depositional environments [Texas]-Field Trip Guidebook, Sept. 30-Oct. 1, 1967: 50 p.

Sontag, Erika, 1966, Mikrobotanische (palynologische) Untersuchungen am 2. Niederlausitzer Flözhorizont: Geologie Beihefte 54, 48 p., 93 pls.

Srivastava, S. K., 1966, Upper Cretaceous microflora (Maestrichtian) from Scollard, Alberta, Canada: Pollen et Spores, v. 8, p. 497552,11 pls.

1969, Some angiosperm pollen from the Edmonton Formation (Maestrichtian), Alberta, Canada, in Santapau, H., and others, eds., J. Sen memorial volume: Calcutta, India, J. Sen Memorial Committee and Botan. Soc. Bengal, p. 47-67.

1972, Some spores and pollen from the Paleocene Oak Hill Member of the Naheola Formation, Alabama (U.S.A.): Rev. Palaeobotany and Palynology, v. 14, p. 217-285, 3 figs., 25 pls.

Stafleu, F. A., and others, eds., 1972, International code of botanical nomenclature adopted by the Eleventh International Botanical Congress, Seattle, August 1969: Utrecht, Netherlands, A. Oosthoek's Uitgeversmaatschappij N.V. for the Internat. Assoc. Plant Taxonomy, 426 p. (In English, French, and German.)

Stanley, E. A., 1965, Upper Cretaceous and Paleocene plant microfossils and Paleocene dinoflagellates and hystrichosphaerids from northwestern South Dakota: Bulls. Am. Paleontology, v. 49, no. 222, p. 177-384, 3 figs., pls. 19-49.

Steenis, C. G. G. J. van, 1962, The land-bridge theory in botany: Blumea, v. 11 , no. 2 , p. 235-542.

Steeves, M. W., and Barghoorn, E. S., 1959, The pollen of Ephedra: Jour. Arnold Arboretum, v. 40, p. 221-255.

Stenzel, H. B., 1940, The Yegua problem: Texas Univ. Pub. 3945, p. 847-910, figs. 129-134, pls. 48-51.

1952a, Boundary problems, in Mississippi Geol. Soc., Claiborne of western Alabama and eastern Mississippi: Mississippi Geol. Soc., Ninth Field Trip, Jackson, Miss., Sept. 26-27, 1952, Guidebook, p. 11-31.

1952b, Transgression of the Jackson Group, in Mississippi Geol. Soc., Claiborne of western Alabama and eastern Mississippi: Mississippi Geol. Soc., Ninth Field Trip, Jackson, Miss., Sept. 26-27, 1952, Guidebook, p. 36-41 and 58-59.

Stover, L. E., and Partridge, A. D., 1973, Tertiary and Late Cretaceous spores and pollen from the Gippsland basin, southeastern Australia: Royal Soc. Victoria Proc., v. 85, p. 237-286, pls. 1328. 
Stover L. E., Elsik, W. C., and Fairchild, W. W., 1966, New genera and species of early Tertiary palynomorphs from Gulf Coast: Kansas Univ. Paleont. Contr.-Paper 5, 11 p., 5 pls.

Straka, Herbert, and Simon, Anke, 1967, Palynologia Madagassica et Mascarenica, Fam. 122-125: Pollen et Spores, v. 9, p. 59-70.

Swift, D. J. P., 1968, Coastal erosion and transgressive stratigraphy: Jour. Geology, v. 76, p. 444-456.

Takahashi, Kiyoshi, 1961, Pollen und Sporen des westjapanischen Alttertiärs und Miozäns (II. Teil): Kyushu Univ. Fac. Sci. Mem., Ser. D, Geology, v. 11, p. 279-345, pls. 13-27.

Tardieu-Blot, M.-L., 1963, Sur les spores de Pterideae malgaches: Pollen et Spores, v. 5, p. $336-353,9$ pls.

1966, Sur les spores de fougères malgaches; Filicales (fin), Marattiales, Ophioglossales (1): Pollen et Spores, v. 8, p. 75-122, 10 pls.

Thiergart, Friedrich, 1938, Die Pollenflora der Niederlausitzer Braunkohle, besonders im Profil der Grube Marga bei Senftenberg: Preuss. Geol. Landesanstalt Jahrb., v. 58 (1937), p. 282-351, pls. $22-30$.

1940, Die Mikropaläontologie als Pollenanalyse im Dienst der Braunkohlenforschung: Schriften aus dem Gebiet der BrennstoffGeologie, no. 13, 82 p., 17 pls.

Thomas, E. P., 1942, The Claiborne: Mississippi Geol. Survey Bull. 48, $96 \mathrm{p}$.

1948, The Jackson (Eocene) and younger beds of west-central Mississippi, in Mississippi Geol. Soc., Upper Eocene, Oligocene, and lower Miocene of central Mississippi: Mississippi Geol. Soc., Sixth Field Trip, [Jackson, Miss.], June 18-20, 1948, Guidebook, p. 17-21.

Thomson, P. W., and Pflug, Hans, 1953, Pollen und Sporen des mitteleuropäischen Tertiärs: Palaeontographica, v. 94, Abt. B., p. 1138,15 pls.

Toulmin, L. D., 1955, Cenozoic geology of southeastern Alabama, Florida, and Georgia: Am. Assoc. Petroleum Geologists Bull., v. 39, p. 207-235, 6 figs.

1962, Geology of the Hatchetigbee anticline area, southwestern Alabama, in Gulf Coast Assoc. Geol. Socs., Little Stave CreekSalt Mountain Limestone, Jackson, Alabama: Gulf Coast Assoc. Geol. Socs., Twelth Ann. Mtg., New Orleans, La., Nov, 3, 1962, Guidebook, p. 1-46, 4 figs., 14 pls.

1969, Paleocene and Eocene guide fossils of the eastern Gulf Coast region: Gulf Coast Assoc. Geol. Socs. Trans., v. 19, p. 465487, 5 figs., 4 pls.

Toulmin, L. D., La Moreaux, P. E., and Lanphere, C. R., 1951, Geology and ground-water resources of Choctaw County, Alabama: Alabama Geol. Survey Spec. Rept. 21, 197 p.

Tourtelot, H. A., 1944, Reconnaissance geologic map of the Quitman fault zone, Clarke and Wayne Counties, Mississippi, and Choctaw County, Alabama: U.S. Geol. Survey Oil and Gas Inv. Prelim. Map 6.
Tralau, Hans, 1964, The genus Nypa van Wurmb: Kgl. Svenska Vetenskapsakad. Handl., ser. 4, v. 10, no. 1, 29 p.

Traverse, Alfred, 1955, Pollen analysis of the Brandon lignite of Vermont: U.S. Bur. Mines Rept. Inv. 5151, 107 p., 13 figs.

Treadwell, R. C., 1954, Moodys Branch-Cockfield contact in Sabine Parish, Louisiana, and adjacent areas: Am. Assoc. Petroleum Geologists Bull., v. 38, p. 2302-2323, 10 figs.

Tschudy, R. H., 1973, Stratigraphic distribution of significant Eocene palynomorphs of the Mississippi embayment: U.S. Geol. Survey Prof. Paper 743-B, 24 p., 2 figs., 4 pls.

1975, Normapolles pollen from the Mississippi embayment: U.S. Geol. Survey Prof. Paper 865, 40 p., 20 pls.

Tschudy, R. H., and Van Loenen, S. D., 1970, Illustrations of plant microfossils from the Yazoo Clay (Jackson Group, upper Eocene), Mississippi: U.S. Geol. Survey Prof. Paper 643-E, 5 p., 5 pls.

Tsukada, Matsuo, 1964, Pollen morphology and identification III. Modern and fossil tropical pollen with emphasis on Bombacaceae: Pollen et Spores, v. 6, p. 393-462, 28 pls.

Van Campo, Madeleine, 1966, Pollen et phylogénie les bréviaxes: Pollen et Spores, v. 8, p. 57-73, 3 pls.

Weyland, Hermann, and Takahashi, K., 1961, Pflanzenreste aus der Braunkohlengrube "Herman" bei Heerlen, holländisch Limburg: Palaeontographica, v. 109, Abt. B, p. 93-107.

Williams, G. L., and Brideaux, W. W., 1975, Palynologic analyses of Upper Mesozoic and Cenozoic rocks of the Grand Banks, Atlantic continental margin: Canada Geol. Survey Bull. 236, 163 p., 15 figs., $47 \mathrm{pls}$.

Willis, J. C., 1966, A dictionary of the flowering plants and ferns, 7th ed., revised by H. K. Airy Shaw: Cambridge, Cambridge Univ. Press, 1, 214 p.

Wilson, L. R., and Webster, R. M., 1946, Plant microfossils from a Fort Union coal of Montana: Am. Jour. Botany, v. 33, p. 271-278, 18 figs.

Wodehouse, R. P., 1933, Tertiary pollen. II, The oil shales of the Eocene Green River formation: Torrey Bot. Club Bull., v. 60, p. 479-524, 54 figs.

-1935, Pollen grains: New York, McGraw-Hill Book Co., 574 p.

Wolff, Herbert, 1934, Mikrofossilien des pliocänen Humodils der Grube Freigericht bei Dettingen a.M., und Vergleich mit älteren Schichten des Tertiärs sowie posttertiären Ablagerungen: Preuss. Geol. Landesanstalt, Inst. Paläobotanik und Petrographie Brennsteine Arb., v. 5, p. 55-86, 3 figs., pl. 5.

Zalinskaya, E. D., 1957, Stratigraficheskoe znachenie pyl'tsy golosemennykh kainozoiskikh otlozhenii Pavlodarskogo Priirtysh’ia i Severnogo Priaralia [Stratigraphic significance of pollen grains of gymnosperms of the Cenozoic deposits of the Irtysh basin and of the northern Aral basin]: Akad. Nauk SSSR Geol. Inst. Trudy, v. 6, 219 p., 17 pls. 


\section{INDEX}

[Italic page numbers indicate the beginning of descriptions and major references]

A

Page

Abietineaepollenites microalatus
sp Pollenites accessorius, Nyssapollenites Acer striatellum Acrostichum aureum acutifolius, Podocarpus -.......- 35 Adiantaceae ...._. Adiantum Leiotriletes adriennis, Leiotriletes
Lygodiumsporites Punctati-sporites afavus, Polypodiisporonites
Verrucatosporites Aglaoreidia cyclops - pristina
Ailanthipites berryi pacatus

Ailanthus

Alabama River

Alangiaceae

barghoorniana $\begin{array}{ll}\text { barghoorniana } & 58 \\ \text { javanicoides } & 58\end{array}$ javanicoides Alangium Albertipollenites araneosus
Alfaroa
alienus, Polypoditsporonites Sporonites

$\begin{array}{cc}\text { Vlnipollenites verus } & 28 \\ & \end{array}$

$\begin{array}{rrr}\text { sp } & & 42 \\ \text { Alnus } & & 42\end{array}$ vera $a$

$$
\text { Amanoa }
$$

$\begin{array}{ll}\text { Amaranthaceae } & 44 \\ \text { ambiguipites, Myriophyllum } & \end{array}$

Amyema subalata

Anacolosa

$$
\text { effatus }
$$

effatus _. 44

andiniformis, Podocarpus aneddenii, Toroisporis _... aneityensis, Symplocos Anemia angustus, Monoleiotriletes - . Rhoipites - Sphagnum
Sphporites, Sphagnumsporites _..... 34

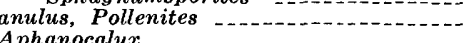

Aphanocalyx

Apocynaceae

Araliaceoipoīlenites

edmundii

granulatus ${ }^{-10}$ megaporifer profundus
aneosus $(-a)$, Albertipollenites araneosus $(-a)$, Albertipollenites
Rousea arcuata, Symplocos
Arecipites Arecipites columes columellus _..... lusaticus pseudoconvexus
punctatus wiesaensis $\begin{array}{ll}\text { argentea, Thrinax } & \\ \text { Armeria } & 45\end{array}$ Armeria $-1,50$ Aspidiaceae
Aspleniaceae
asymmetricus, Monosulcites aureum, Acrostichum Symplocos australis (-um), Sphagnites
Sphagnum Sphagnum Stereisporites -
Triletes

Auversian Stage

\section{B}

Baculatisporites primarius $-31,32$

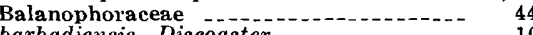
barbadiensis, Discoaster ........... 10 barclayi, Rhus Bartonian Stage (England)
bellus, Foveostephanocolporites $--28,64 ;$ pl. 16 Belotia
berryi, Ailanthipites Betula setulaceoipollenites bituitus biformis, Selaginella $\begin{array}{ll}\text { bituitus, Betulaceoipollenites } & 41 \\ \text { Blechnaceae } & \end{array}$ Blechnaceae
Boehlensipollis hohlii Bombacaceae
Bombacacidites nacimientoensis reticulatus _..._... 60 bradleyi, Rhoipites Brahea

breuhlensis, Pollenites cingulum

$\begin{array}{ll}\text { breuhlensis, Pollenites cingulum --..- } & 51 \\ \text { brevicolpatus, Retitetracolpites } & 49\end{array}$ brevicolpatus, Retitetracolpites
brevis, Tetracolporopollenites brevisulcatum (-us)

$$
\begin{array}{r}
\text { Chrysophyllum } \\
\text { Cupuliferoipollenites }
\end{array}
$$

bruehlensis, Tricolporopollenites

Bruniaceae megaexactus _..-_..... 51

$\begin{array}{llr}\text { Bruniaceae } & \\ \text { Bullasporis } & - & 50\end{array}$

sp
Bumelia

C

Calamospora _-_._. 31

Calamuspollenites cocenicus
calaensis, Porocolpopollenites Symplocos
Sidus, Ericipites Camarozonosporites hamulatis heskemensis cappulatus, Podocarpus _.... 22, 23, 34; pl. Caprifoliaceae incertigrandis microreticulatus tantulus $\begin{array}{rr}\text { viridi-fluminis } & 57 \\ \text { Cardioangulina diaphana } & \end{array}$ Carya simplex veripites sp
Caryapollenites simplex $\begin{array}{rrr}\text { sp } & \\ \text { Cassia } & & 42 \\ \end{array}$ certa
Castanea $\begin{array}{rr}\text { sp } & \mathbf{5 0} \\ \text { Castanopsis } & \end{array}$

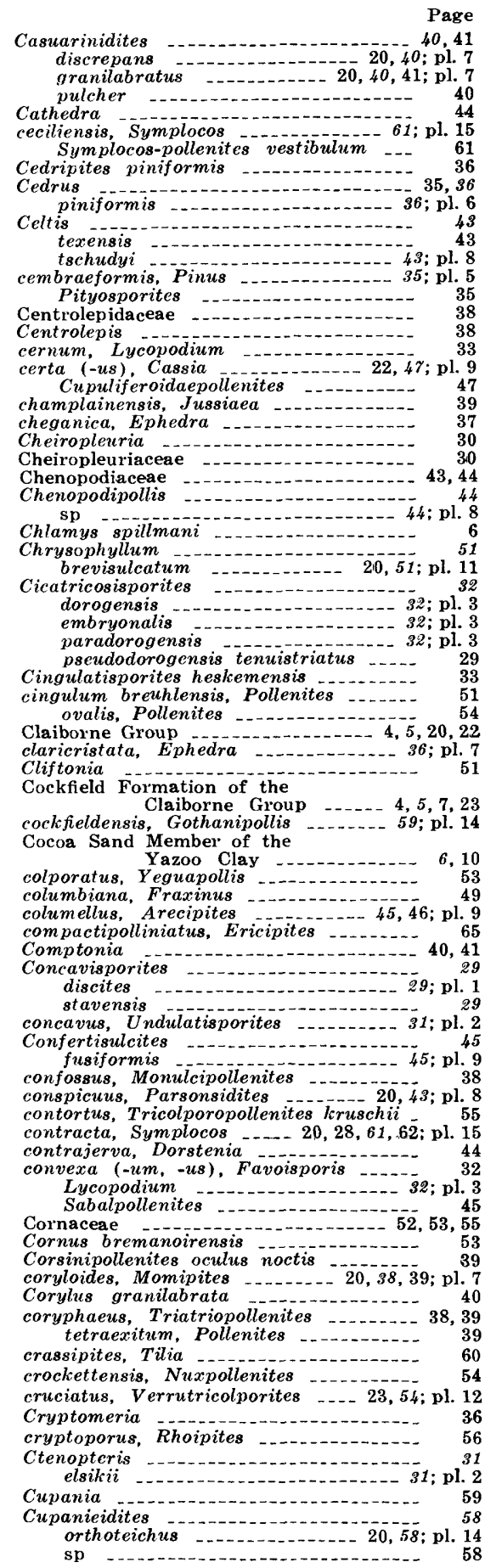




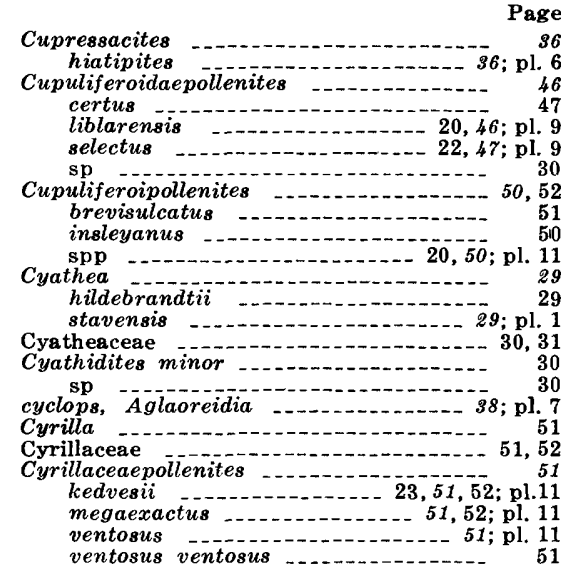

\section{D}

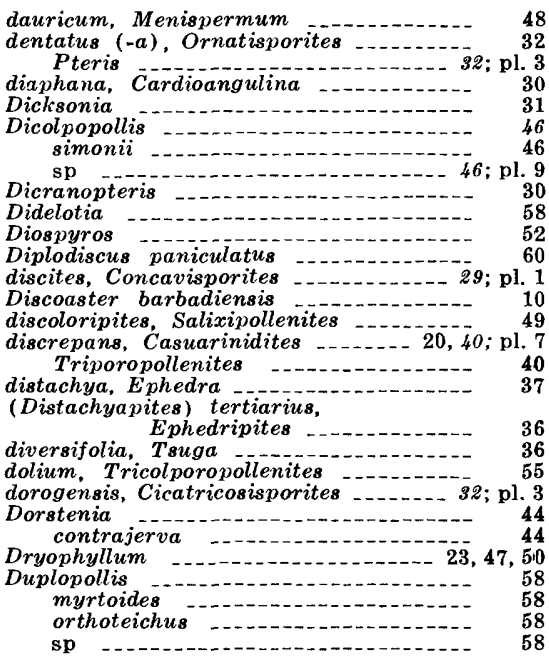
$\mathbf{E}$

Ebenaceae cchinata (-us), Nypa
Spinizonocolpites $\begin{array}{rr}\text { Spinizonocolpites } & 46 \\ \text { Echiperiporites tschudy } i \text { - } & 44\end{array}$ edmundit, Araliaceoipollenites efflatus, Anacolosidites -
Sporites Elaeagnaceae lsikii, Ctenopteris Undulatisporites
mbryonalis, Cicatricosisporites Engelhardtia $\begin{array}{ll}\text { microfoveolata } & 39 \\ \text { spackmaniana } & 39\end{array}$ $\begin{array}{lr}\text { spackmaniana } & 39 \\ \text { sp } & 38 \\ & \end{array}$ engelhardtii, Trivestibulopollentes
Engelhardtioidites microcoryphaeus $-41 ;$ pl. 8
eocenicus $(-a)$, Calamuspollenites -.. 46 ; pl. 9 Ephedra
Ephedra Gnetaceaepollenites Ephedra cheganica claricristata $^{-3}, 37$ \begin{tabular}{ll}
37 \\
-- & 36 \\
\hline
\end{tabular} cocenipites exiguua hungarica laevigataeformis
voluta sp

Ephedripites hungaricus $\begin{array}{ll}\text { (Disaticus } & 37 \\ \text { (Distachyapites) tertiarius } & \end{array}$

$\begin{array}{lll}\text { Ericaceae } & \\ \text { Ericipites } & - & 65\end{array}$ $\begin{array}{ll}\text { acastus } & \text { callidus } \\ \text { compan }\end{array}$ compactipolliniatus
ericius $\ldots \ldots$
Ericipites-Continued longisulcatus redbluffensis
ericius, Ericipites

Pollenites
Ericius,

Escalloni

Eugenioides

eugenioides, Loranthus

Euphobia -

Euphorbiaceae

exiguua, Ephedra _............ 23, 37; pl. ?

fracturopollenites

fractus

terminalis

\section{F}

Fagaceae $\ldots$ $\begin{array}{ll}\text { Favoisporis convexa } & \\ \text { favus, Poly podisporites } & \end{array}$ favus, Polypodisporites
Polypodiisporonites
Reticis $\begin{array}{lll}\text { Polypodiisporonites } & -\cdots-1-128,29 ; & \text { pl. } 1 \\ \text { Reticuloidosporites } & -\end{array}$

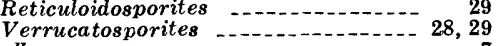
Flabellum sp Flagellariaceae fagellata, Selaginella Forest Hill Sand of the Vicksburg

Group ${ }_{\text {formosus, Pollenites }}$ formosus, Pollenites
fossulatus, Tricolporopollenites

foveolatus, Inaperturopollenites Tricolporopollenites hoshuyamaensis Foveostephanocolporites bellus liracostatus Foveotricolpites prolatus rhombohedralis fractus, Extratriporopollenites Fraxinoipollinites -... 48 medius
scoticus scoticus
variabilis $-\ldots \ldots$ spp Fraxinu columbiana remontodendron Fremontodendron
fruticans, Nypa fusiformis, Confertisculcites
Ephedra G

Gale ${ }_{\text {gemmata, }}$ Symplocos genuina (-us), Horniella Pollenites glauca, Symplocos Gleichenia Gleicheniaceae - 28,30 Gleicheniidites
senonicus
sen globiformis, Pollenites Glyptostrobus Gosport Sand of the Claiborne Group - 4, 5, 77 Gothanipollis
cock fieldensis $\begin{array}{rr}\text { sp } & 59 \\ \text { racilis, Graminidites } & \mathbf{3 7}\end{array}$ Monoleiotriletes -..- 31 Graminead -138 gramineoides, Graminidites
Monoporopollenites Graminidites
gracilis gramineoides sp
Grammitidaceae $\begin{array}{cr}\text { grandivescipites, } & \text { Picea } \\ \text { Piceapollis } & 31 \\ \text { granifer maternus, Pollenites } & 36 \\ \text { granilabratus } & \end{array}$ granilabratus (-a),
Casuarinidites

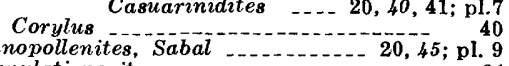
Granulatisporites
luteticus granulatus (-um), Araliaceoipol-

Pollenites pseudocingulum $20,23,52 ;$ pl. 11

\section{$\mathbf{H}$}

haardti, $\begin{aligned} & \text { Sporites } \\ & \text { hardtii, Laevigatosporites }\end{aligned}$ age

5
6
6
4
0
8
9
3
0
7
1
0

$\begin{array}{ll}\text { Haloragacidites trioratus } & \\ \text { Hamamelis scotica }\end{array}$

hamulatis (-um), Camarozonosporites --
Hamulatisporis

Hamulatisporis
Lycopodium

Hamulatisporis hamulatis

haraldii, Tricolpopollenites _-_._._.-.- 48

helmstedtensis, Tricolporopollenites - $\quad 55$

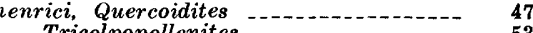
$\begin{array}{ll}\text { Tricolpopollenites } & \mathbf{5 3} \\ \text { microhenrici, Pollenites } & 47\end{array}$

heskemensis, Camarozonosporites -..-- 33 Cingulatisporites
Lycopodium hiatipites, Cupressacites -... $\begin{array}{cc}\text { Taxodium } & 36 \\ \text { hiatus, Inaperturopollenites } & 36\end{array}$ $\begin{array}{ll}\text { Pollenites } & 36 \\ \text { Taxodiaceaepollenites } & 36\end{array}$ $\begin{array}{rr}\text { Taxodiaceaepollenites } & 36 \\ \text { Hicoria viridi-fluminipites } & 42\end{array}$

hildebrandtii, Cyathea -

Hippomane
hohlii, Boehlensipollis
Horniella

Horniella genuina
modica modica secreta
spp hoshuyamaensis, Tricolporopollenites 56 ; pl. 13

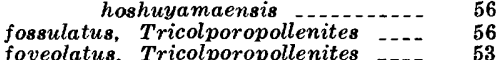
foveolatus, Tricolporopollenites -53 hungarica (-us), Ephedra _........- 37; pl. 7 Milfordia hypolaenoides, Milfordia

igniculus $(-a)$, Sporonites -......- 36 Tsuga Zonalapollenites

Ilex iliaca infissa
media

lexpollenites iliacus

$\begin{array}{cc}\text { sp } & \mathbf{5 3} \\ \text { iliaca }(-\mathrm{us}) \text {, Hex } & \text { Ilex }\end{array}$ $\begin{array}{cr}\text { Ilexpollenites } & 53 \\ \text { illiacus medius, Tricolporopollenites } & 53 \\ \text { inamoenus, Quercoidites } & \\ \text { Tricolpopollenites } & \end{array}$ $\begin{array}{rr}\text { Tricolpopollenites } & 47 \\ \text { Inaperturopollenites hiatus } & 36\end{array}$ incertus foveolatus
incerta (-us), Milfordia foveolatus, Inaperturopollenites -38 incertigrandis, Caprifoliipites - 23, 56, $5 \overline{7} ; \mathrm{pl} .13$ infrsa, Ilex -12 infrabaculatus, Juglanspollenites
insleyanus, Cupuliferoipollenites instructus $(-a)$, Intratriporopollenites
Tilia Tilia Tiliapollenites intergranulata, Reticulataepollis -..- 60 intrabaculatus, Tricolpopollenites
microhenricii microhenricii
intragranulatus, Tricolpopollenites
microhenricii Intratriporopollenites $\begin{array}{ll}\text { instructus } & \\ \text { magnificus } & 59\end{array}$ neumarkensis inundatum, Lycopodium

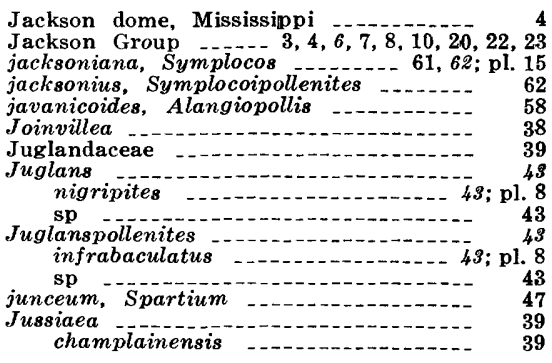
champlainensis

Kedvesii, Cyrillaceaepollenites - 23. 51,52; pl. 11 Kruschia,
Pollenites 
Page

kruschii, Nyssa $\begin{array}{ll}\text { Tricolporopollenites } & \\ \text { contortus, Tricolporopollenites } & \ldots\end{array}$ $\mathbf{L}$

labatlanii, Tricolporopollenites _-_._. 5 Pityosporites - Pinus -
Pollenites Pollenites -
abratum, Lygodium 35 laesius, Pollenites laevigata, Schizaea
laevigataeformis, Ephedra $\begin{array}{cc}\text { Schizaea } & 37 \\ \text { Laevigatosporites } & \end{array}$ haardtii - 28 pl. 1 lapillipites, Sequoia Sequoiapollenites
tiporis, Porocolpopollenites Symplocos
Symoris Symplocos
latus, Rhoipites

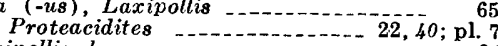
Laxipollis laxa Leguminosae adriennis $\begin{array}{ll} & 30 \\ \text { microadriennis } & 31\end{array}$ mereuxiana (-us), Manilkara Sapotaceoidaepollenites
Tetracolporopollenites
-

libella, Podocarpus Pollenites Cupuliferoidaepollenites 20, 46; pl. Tricolpopollenites Ligustrum ovalifolium _............ 60

Liliacidites variegatus vittatus sp

Linaceae

liracostatus, Foveostephanocolporites $\quad 64$

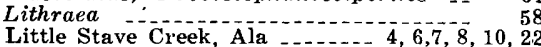
Locality register _._._._._._..... 10, 11 Lomariopsidaceae Pinus longifoliaformis, Pinus
Pityosporites longisulcatus, Ericipites longitora, Toroisporis _
Lonicerapollis Loranthaceae Loranthus eugenioides
Ludwigia oculus-noctis lusaticus, Arecipites Ephedripites Lusatisporis perinatus Punctatisporites convexum convexum heskemensis heskemensis
inundatum phlegmaria venustum

Lygodium Labratum
adriennis adriennis
rhetor rhetor

M

Maceration procedures

magnificus, Intratriporopollenites

Magnoliaceae
magnus, Transdanubiaepoilenites
Malvaceae

Malvacipollis ${ }^{-1}$ tsch udyi
anifestus, Pollenites Sapotaceoidaepollenites Tetracolporopollenites

Manilkara
lesquereuxiana

Mastixia - Pollenites

maternus, Pollenites Triporopollenites

maximus, Podocarpus _. Fraxinoipollenites $\ldots$ Ilex
Trico Tricolporopollenites megadolium, Pollenites Sapotaceoidaepollenites
Tetracolporopollenites megaexactus, Cyrillacaepollenites _- 51,$52 ; \mathrm{pl} .11$

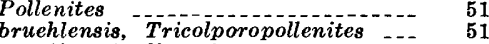
megaporifer, Araliaceoi-

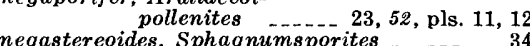
gastereoides, Sphagnumsporites
Stereisporites Stereisporites -
4 Menispermaceae

Menispeticum

scoticum

36

Punctatisporites

microalatus, Abietineaepollenites

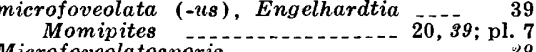
pseudodentata icrohenrici, Pollenites Pollenites henrici Tricolpopollenites microhenricii, Quercoidites - $20,47,52 ; \mathrm{pl} .10$ intrabaculatus, Tricolpopollenites

microporifer, Tricolporopollenites

microreticulatus, Caprifolitpites

Symplocos

Milfordia

hungarica

hypolaenoides

incerta minor, Matfordia ............. 22, 38; pl. 7 modica (-us), Horniella Pollenites

Mohria (tes coryloides
microfoveolatus sp -

monilifera, Rousea

onocolpopollenit
nupharoides

tranquilloides tranquillus

Monoleiotriletes angustus
gracilis

sp onopopollenites poropollenites gramineoides sp asymmetricus - $44 ; \mathrm{pl} .9$ $\begin{array}{rr}\mathrm{sp} & 45,46 \\ \text { Monulcipolienites } & \end{array}$ confossus
oodys Branch Formation of the

Moodys Brackson Group _._._. 6, 7, 10 Muerrigerisporis _._. 33 Multiporopollenites $\mathrm{sp}$ Mropria - $\quad 40,41$ $\begin{array}{ll}\text { propria } & \\ \text { Myricipites speciosus } & 41\end{array}$ ambiguipites sp ambiguipites $\begin{array}{lll}\text { Myristica } & \\ \text { Myristicaceae } & 46\end{array}$ $\begin{array}{lll}\text { Myrtaceae } & 58 \\ \text { Myrtaceidites } & \end{array}$ parvus parvus anesus nesus

parvus
myrtoides, Duplopollis
Myrtus

\section{N}

nacimientoensis, Bombacacidites_._. 59 ; pl. 14 $\begin{array}{ll}\text { navicula, Pollenites } & \\ \text { Nephrolepis } & \end{array}$ nesus, Myrtaceidites parvus neumarkensis, Intratriporopollenites -- 60 noctis, Corsinipollenites oculus North Twistwood Creek Member of

the Yazoo Clay _....... 6, 10 tschudyi sp
Page Nudopollis $\quad$ terminalis $\begin{array}{ll}\text { sp } & \\ \text { sp } & 62 \\ \text { upharoides, Monocolpopollenites } & \end{array}$ $\begin{array}{ll}\text { nupharoides, Monocolpopollenites } & -\cdots-1 \\ \text { Nuxpollenites } & 46\end{array}$ crockettensis Nyctaginaceae Nyctaginaceae
Nymphaeaceae Nypa echinata fruticans kruschii sp Nyssaceae
Nyssapollenites accessorius
pulvinus

pulvinus
Nyssoidites

\section{o}

Ocala Limestone
occidentalis, Platanus occidentalis, Platanus
occidentaloides, Platanus oculus noctis, Corsinipollenites -_.... 39 noctis, Pollenites
Ludwigia Ludacacea Olea

Oleandraceae Porocolpopollenites orbiformis, Porocolpopollenites
Symplocos Oreomunnea
Ornatisporites dentatus
orthoteichus, Cupanieidites Duplopollis $\ldots$-.
Osmunda Osmunda $\quad$ rimaria Osmundacidites wellmanii $\begin{array}{rr}\text { sp } & \\ \text { Ostrya } & \end{array}$ ovalifolium, Ligustrum Pollenites cingulum Verrutricolporites

pacatus $(-a)$, Ailanthipites $-.-22,51,5 \overline{2} ;$ pl. 11 Siltaria Pachuta Marl Member of the Palmae Yazoo Clay Palmaepolienites tranquillus paniculatus, Diplodiscus - pseudocruciatus 60 paradorogensis, Cicatricosisporites _._ 32 ; pl. 3 parmularius, Tricolpopollenites _... 47 Parsonsidites Parthenocissus parvus, Myrtaceidites Myrtaceidites parvus
Salixipollenites Sanesus, Myrtaceidites
anes. nesus, Myrtaceidites parvus, Myrtaceidites
Pedaliaceae penicillata, Schizaea perinatus, $(-a)$, Lusat isporis
Selaginella Phaeoptilum

phlebodium

$\begin{array}{ll}\text { Phoenix } & \\ \text { Phoradendron } & \end{array}$

Phoradendron
Picea grandivescipites
Piceapollis grandivescipites Picrodendraceae
pielii, Fraxinus piniformis, Cedripites
Cedrus Pinus cembraeformis Labdaca longifoliaformis ponderosaeformis Pinuspollenites -... 35 $\begin{array}{rr}\text { Pityosporites } & \\ \text { cembraeformis } & 35 \\ \text { labdacus } & \end{array}$ $\begin{array}{ll}\text { cembraeformis } & 35 \\ \text { labdacus } & \end{array}$ lobdacus ponderosaeformis

Planera
thompsoniana 


\begin{tabular}{|c|c|c|}
\hline Page & Page & Page \\
\hline Platanus & Proteacidites & Salixipollenites \\
\hline mullensis & $-22,40 ;$ pl. 7 & discoloripites \\
\hline occidentalis & terrazus & parvus _... \\
\hline $\begin{array}{l}\text { occidentaloides } \\
\text { Platycarya }\end{array}$ & thalmanni & $\begin{array}{r}\text { trochuensis - } \\
\text { Sambucus }\end{array}$ \\
\hline $\begin{array}{c}\text { Platycarya } \\
\text { sp }\end{array}$ & $\begin{aligned} & \text { sp } \ldots \\
& \text { Prunus }\end{aligned}$ & $\begin{array}{l}\text { Sambucus } \\
\text { Sampling, methods }\end{array}$ \\
\hline Plicapollis & pseudocingulum, Pollenite & Sapindaceae \\
\hline spatiosa & Rhoipites & Sapotaceae - \\
\hline Plumbaginaceae & granulatum, Pollenite & Sapotaceoidaepollen \\
\hline Podocarpus _........ & $\begin{array}{l}\text { rauff, Pollenites } \\
\text { eudoconvexus, Arec }\end{array}$ & $\begin{array}{l}\text { manifestus } \\
\text { megadolium }\end{array}$ \\
\hline $\begin{array}{l}\text { acutifolius } \\
\text { andiniformis }\end{array}$ & pseudocruciatus, pan & sp \\
\hline cappulatus & $\begin{array}{l}\text { pseudodentata, Microfove } \\
\text { pseudolaesus, Pollenites }\end{array}$ & $\begin{array}{l}\text { scabriextima, Siltar } \\
\text { scabripollinia, Symy }\end{array}$ \\
\hline $\begin{array}{l}\text { libella } \\
\text { maximus }\end{array}$ & Pseudopheonix sp. & $\begin{array}{l}\text { scabri } \\
\text { Schizo }\end{array}$ \\
\hline $\begin{array}{l}\text { maximus } \\
\text { standleyi }\end{array}$ & pseudodorogensis tenuistr & igata \\
\hline 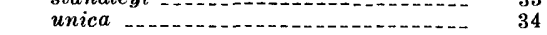 & Cicatr & ataeformis \\
\hline sp & $\begin{array}{c}\text { psilatus, Stereisporites } \\
\text { Triletes }\end{array}$ & $\begin{array}{l}\text { penicillata } \\
\text { pusilla }\end{array}$ \\
\hline Pollenites _........... & $\begin{array}{l}\text { Triletes } \\
\text { Psilotaceae }\end{array}$ & $\begin{array}{l}\text { pusilla } \\
\text { tenuistriata }\end{array}$ \\
\hline $\begin{array}{l}\text { acastus } \\
\text { anulus }\end{array}$ & Psilotum & $29,30,32$ \\
\hline $\begin{array}{l}\text { cingulum bruehler } \\
\text { ovalis }\end{array}$ & $\begin{array}{l}\text { Pteridaceae } \\
\text { Pteris }\end{array}$ & $\begin{array}{l}\text { schwarzbachi, Poro } \\
\text { schwarzbachii, Sym }\end{array}$ \\
\hline coryphaeus tetrae & $\begin{array}{r}\text { dentata } \\
\text { Pterocarya }\end{array}$ & $\begin{array}{c}\text { scoticus }(-a,-u m), \\
\text { Hamamelis }\end{array}$ \\
\hline $\begin{array}{l}\text { ericius } \\
\text { formosus }\end{array}$ & stellata & nispermum \\
\hline genuinus & $\begin{array}{r}\text { vermontensis } \\
\text { Pterocaryapollenites }--\end{array}$ & $\begin{array}{l}\text { secreta }(-u s), \text { Horn } \\
\text { Pollenites }\end{array}$ \\
\hline globiformis & $\begin{array}{r}\text { Pterocaryapoltenites } 8 \\
\text { vermontensis }\end{array}$ & Selaginella \\
\hline $\begin{array}{l}\text { granifer maternus } \\
\text { henrici microhenrici }\end{array}$ & Ptychopetalum & biformis \\
\hline is $\ldots \ldots \ldots \ldots$ & $\begin{array}{l}\text { pulcher, Casuarinidites } \\
\text { pulvinus, Nyssapollenites }\end{array}$ & $\begin{array}{l}\text { Hagellata } \\
\text { perinata }\end{array}$ \\
\hline labdacus & Pollenites & sinuites \\
\hline laesius & $\begin{array}{c}\text { Punctatisporites } \\
\text { adriennis }\end{array}$ & $\begin{array}{lll}\text { sp. } & \text { A } & \cdots-\cdots- \\
\text { sp. } & \text { B } & -\cdots\end{array}$ \\
\hline $\begin{array}{l}\text { liblarensis } \\
\text { manifestus }\end{array}$ & luteticus & selectus, Cupulifero \\
\hline maternus & $\begin{array}{l}\text { microadriennis } \\
\text { nctatus. }\end{array}$ & $\begin{array}{l}\text { Pollenites } \\
\text { senonicus, Gleichen }\end{array}$ \\
\hline megadolium _- & $\begin{array}{l}\text { nctatus, Arecipites - } \\
\text { silla, Schizaea }\end{array}$ & $\begin{array}{l}\text { senonzus, Gieichen } \\
\text { Sequoia }\end{array}$ \\
\hline $\begin{array}{l}\text { megaexactus } \\
\text { microhenrici }\end{array}$ & Pustechinosporis & lapillipites -.. \\
\hline $\begin{array}{l}\text { meronenrict } \\
\text { modicus }\end{array}$ & & $\begin{array}{c}\text { Sequoiapollenites } \\
\text { lapillipites }\end{array}$ \\
\hline $\begin{array}{l}\text { navicula } \\
\text { oculus noctis }\end{array}$ & $\mathbf{Q}$ & a serrulata \\
\hline $\begin{array}{l}\text { oculus noctis } \\
\text { pseudocingulum }\end{array}$ & Quercoidites & ata, Serenoa \\
\hline $\begin{array}{l}\text { ganulatum } \\
\text { rauffi }\end{array}$ & henrici & $\begin{array}{l}\text { Shubuta Hill } \\
\text { Shubuta Member of the Yazoo }\end{array}$ \\
\hline $\begin{array}{c}\text { rauffi } \\
\text { pseudocruciatus panthe }\end{array}$ & $\begin{array}{l}\text { inamoenus } \\
\text { microhenricii }\end{array}$ & Clay \\
\hline pseudolaesus & Quercus & Siltaria \\
\hline pulvinus & sp $\ldots$ & briextima \\
\hline 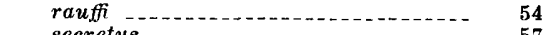 & & $56,58,60$ \\
\hline $\begin{array}{l}\text { secretus } \\
\text { selectus }\end{array}$ & $\mathbf{R}$ & simonii, Dicolpopollis \\
\hline $\begin{array}{l}\text { selectus } \\
\text { simplex }\end{array}$ & aut & simplex, Carya \\
\hline stellatus & Poll & $\begin{array}{l}\text { Caryapollenites } \\
\text { Pollenites }\end{array}$ \\
\hline tranquillus $\ldots$ & Red Bluff Clay o & \\
\hline $\begin{array}{l}\text { triangulus } \\
\text { ventosus }\end{array}$ & $7,8,10,20,22$ & 42 \\
\hline $\begin{array}{l}\text { ventosus } \\
\text { verus }\end{array}$ & Bis, Ericipites & aginella \\
\hline vestibulum & $\begin{array}{l}\text { Restio sp } \\
\text { Restionaceae }\end{array}$ & king proced \\
\hline Polyatrio-pollenites stellatus & Restioniidites & na, Enge \\
\hline Polycolpites & reticlavata, Reticulataep & Sparmannia \\
\hline nensis ..... & pollis ..... & $\begin{array}{l}\text { Spartum ounceum } \\
\text { spatiosa, Plicapollis }\end{array}$ \\
\hline sp $\ldots \ldots \ldots$ & anulata & us, Myricipites \\
\hline Polygalaceae & ata $a t a-23,60 ;$ pl. 14 & ites australis \\
\hline Polypodiaceae & $\ldots+\ldots$ & Sphagnum \\
\hline Polypodiidites & $\begin{array}{l}\text { Tricolpopolle } \\
\text { Reticuloidosnorit }\end{array}$ & antiquasporites \\
\hline Polypodiisporites _-_- & $\begin{array}{l}\text { Reticuloidosporites favus } \\
\text { retiformis, Tricolpopollenites }\end{array}$ & alum \\
\hline faves & $\begin{array}{l}\text { Tricolpopoue } \\
\text { lpites brevico }\end{array}$ & jides \\
\hline Polypodiisporonites - 28 & Retitrescolpites & $\begin{array}{l}\text { arum }--- \\
\text { porites }\end{array}$ \\
\hline afavus _- & sp & $\begin{array}{l}\text { porites a } \\
\text { is }\end{array}$ \\
\hline $\begin{array}{l}\text { alienus } \\
\text { Polypodiumsporites sp }\end{array}$ & rhetor, Lymingtonia & astercoides \\
\hline favus & $-52,55,56$ & -- \\
\hline Polyporopollenites stellatus & bradleyi & spillmani, Chlamys \\
\hline 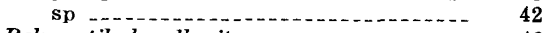 & toporus & $\begin{array}{l}\text { Pnizonocorpites } \\
\text { echinatus }\end{array}$ \\
\hline opollenites verus - & .. $23,55,56 ;$ pl. 13 & Spond \\
\hline rmis, Pinus _... & pseudocingulum & Sporites efflatus \\
\hline rites & latus & \\
\hline llenites & rhombohedralis, Foveotricolporites _-..- 53 & ius \\
\hline 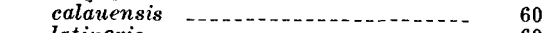 & Rhus & \\
\hline is & Rio Grande embayment, Mississippi & tes alienus _... \\
\hline $\begin{array}{l}\text { microvestibulum } \\
\text { orbiformis }\end{array}$ & Riverside Park, Jackson, Miss & igniculus \\
\hline mbachis & Rosaceae & $\begin{array}{l}\text { stanaleyn, Paocarpus } \\
\text { stavensis, Concavisporites }\end{array}$ \\
\hline buloformis & Rousea & 1. 1 \\
\hline$m-1-1-n-1-1$ & $\begin{array}{l}\text { araneosa } \\
\text { monilifera }\end{array}$ & oropoll \\
\hline -............ & $\begin{array}{l}\text { monilifera } \\
\text { Rubiaceae }\end{array}$ & a), Pollenites \\
\hline Toroisporis - & $\begin{array}{l}\text { Kubraceae } \\
\text { Ruppiaceae }\end{array}$ & Polyporopollenites - - \\
\hline Potamogetonaceae & $\begin{array}{l}\text { Rup piaceae } \\
\text { Rutaceae }\end{array}$ & $\begin{array}{l}\text { Polyatrio-pollenites } \\
\text { Pterocarya }\end{array}$ \\
\hline $\begin{array}{c}\text { primarius }(-a), \text { Baculatisporites } \ldots-\ldots, 31,32 \\
\text { Osmunda }\end{array}$ & Rutaceae & aryapollenites \\
\hline Sporites & $\mathbf{S}$ & ae \\
\hline pristina, Aglaoreidia $\ldots \ldots \ldots 20,22,38 ; \mathrm{pl} .7$ & & tes $\ldots \ldots \ldots$ \\
\hline profundus, Araliaceoipollenites _- 23, 53; pl. 12 & $20,45 \cdot p^{45}$ & stis \\
\hline olatus, Foveotricolpites _....... & balpol & 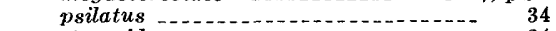 \\
\hline pria & salebrosus, $\mathrm{Tr}$ & \\
\hline Triatriopollen & licaceae & \\
\hline roteaceae & Salix & woelfersheimensis \\
\hline
\end{tabular}




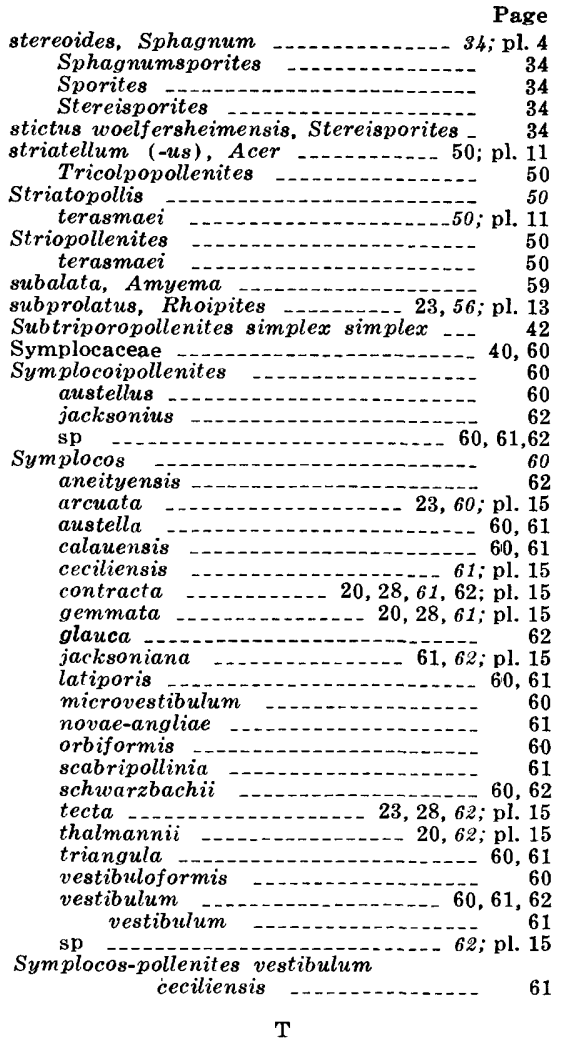

tantulus, Caprifoliipites _....... 20,57; pl. 14 Taxodiaceae - 36 $\begin{array}{ll}\text { Taxodiaceaepollenites hiatus } & 36 \\ \text { Taxodium } & \end{array}$ hiatipites tenuextima, Pinus tenuistriatus $(-a)$, Cicatricososporites

Sseudodorogensis _..... 29 Schizaea
erasmaei, Striatopollis $\ldots$. $\begin{array}{rr}\text { Striopollenites } & 50 \\ \text { terminalis, Extratriporopollenites } & 62 \\ \text { Nudopolls }\end{array}$ Nudopollis tertiarius, Ephedripites (Distachyapites) 36 Tetracolporites sp _........ 55 Tetracolporopollenites brevis
lesquereuxianus manifestus megadolium sp texensis, Celt is $\begin{array}{lr}\text { thalmanni, Proteacidites } & 62 \\ \text { thalmannii, Symplocos }\end{array}$ thomassi, Tricolpites

41 magnifica

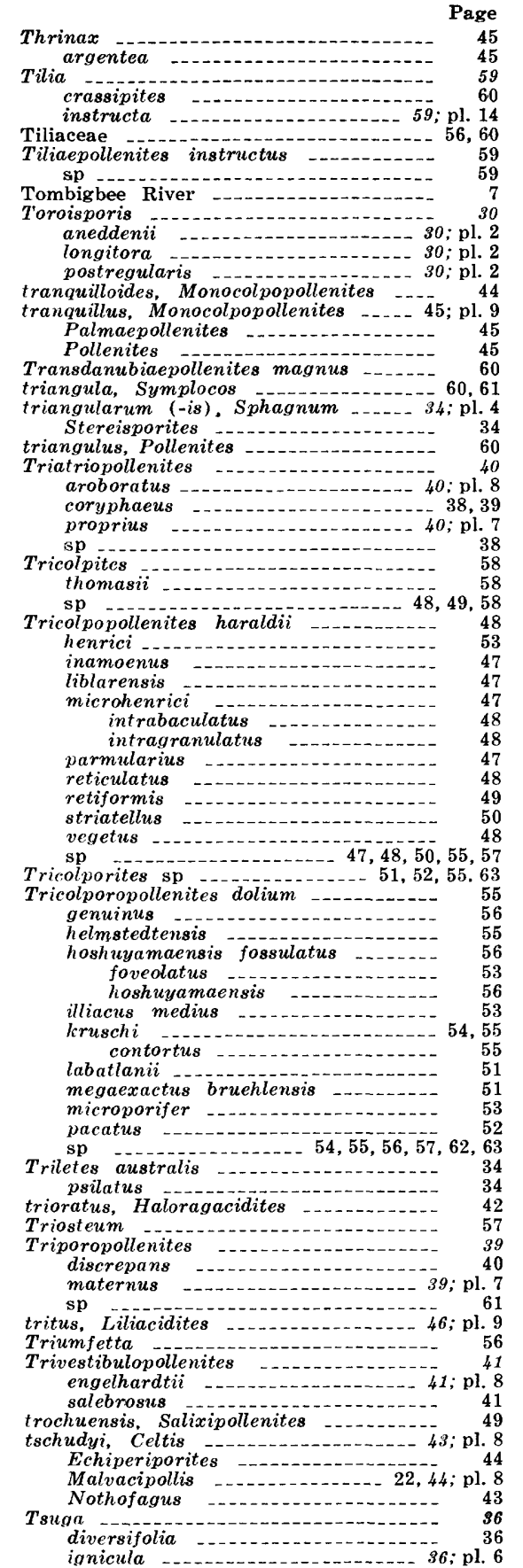

Tsugaepollenites igniculus Page

U

Ulmipollenites undulosus

Ulmus

Umbellifera

dulatisporites elsikii sp $\begin{array}{ll}\text { undulosus, Ulmipollenites } & \\ \text { unica, Podocarpus }\end{array}$

$\mathrm{V}$

variabilis, Fraxinoipollenites _._.... 48; pl. 10 variegatus, Liliacidites, ventosus, Cyrillaceaepollenites $\ldots \ldots-5 \overline{1} ; \mathrm{pl} .11$ Cyrillaceaepollenites ventosus ...- 51 $\begin{array}{ll}\text { Pollenites } & 51 \\ \text { ventosus, Cyrillaceaepollenites } & 51\end{array}$ venustum, Lycopodium _.......... 33; pl. 3 vera, Alnus _...... $42 ; \mathrm{pl} 8$ veripites, Carya _........... 22,$42 ; \mathrm{pl} .8$ vermontensis, Pterocarya ........... 43 Pterocaryapollenites ........... 43

Verrucatosporites _............. 28 afavus favus favus $\ldots . \ldots \ldots$ Vcrrutricolporites _... cruciatus _... ovalis _.................. 23,54 ; pl. 12 tenuicrassus $\begin{array}{rr}\text { vcrsus, Alnipollenites } & 42 \\ \text { Pollenites } & 42\end{array}$ Pollenites vestibuloformis, Porocolpopollenites -..- 60 Symplocos vestibulum, Pollenites Symplocopollenites Symplocos ctciliensis, Symplocos-pollenites -..- 61 vestibulum, Sym plocos _._. 61 Vicksbur'g Group _......... 4, 7, 8, 20, 22, 23 viesenensis, Polycolpites _... viridi-fluminipites, Hicoria viridi-fluminis, Caprifoliipites $\quad 57$ Vitaceae vittatus, Liliacidites W

\section{W}

wcllmanii, Osmundacidites _..._.....- $\quad 32$ wosaensis, Arecipites

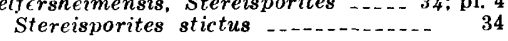

$\mathbf{Y}$

Yazoo Clay of the Jackson $6,7,8,10,20,22,23$ yeguaensis, Liliacidites
Yeguapollis colporatus $\mathbf{Z}$

$\begin{array}{lll}\text { Zanthoxylum } & \\ \text { Zelkova } & & \mathbf{5 7}\end{array}$ Zonalapollenites igniculus 



\section{PLATES 1-16}

Contact photographs of the plates in this report are available, at cost, from U.S. Geological Survey Library, Federal Center, Denver, Colorado 80225. 


\section{PLATE 1}

[Magnification $\times 1,000]$

FIGURE 1. Laevigatosporites haardtii (p. 28).

Slide 10696 A-1, coordinates $23.4 \times 109.7$

2. Polypodiisporonites alienus (p. 28).

Slide $10663 \mathrm{~A}-1$, coordinates $34.4 \times 117.8$.

3. Polypodiisporonites favus (p. 29).

Slide $10680 \mathrm{~A}-1$, coordinates $39.4 \times 123.6$.

4. Microfoveolatosporis pseudodentata (p. 29).

Slide 10627 A-1, coordinates $25.1 \times 123.7$.

5. Polypodiisporonites afavus (p. 28).

Slide $10556 \mathrm{~A}-1$, coordinates $37.4 \times 127.3$.

6. Schizaea tenuistriata (p. 29).

Slide $10663 \mathrm{~A}-1$, coordinates $21.5 \times 124.2$.

7. Cyathea? stavensis (p. 29).

Holotype. Slide 10558 A-1, coordinates $35.7 \times 123.1$.

8. Gleicheniidites senonicus (p. 29).

Slide 10864 A-2, coordinates $20.3 \times 115.3$.

9. Concavisporites discites (p. 29).

Slide 10650 A-2, coordinates $34.1 \times 122.2$.

10-11. Lygodium labratum (p. 30).

Holotype. Slide $10656 \mathrm{~A}-2$, coordinates $21.2 \times 118.0$.

12-13. Lygodiumsporites adriennis (p. 30).

12. Atypical specimen except that the exine is slightly thinner thanusual. Slide $10620 \mathrm{~A}-1$, coordinates $16.0 \times 110.1$.

13. A specimen that is atypical of the species because it is more nearly round than triangular in outline. Slide 10558 A-1, coordinates $41.5 \times 117.6$.

14. Lygodiumsporites? cf. L. adriennis (p. 30) Slide $10558 \mathrm{~A}-1$, coordinates $26.4 \times 115.4$. 

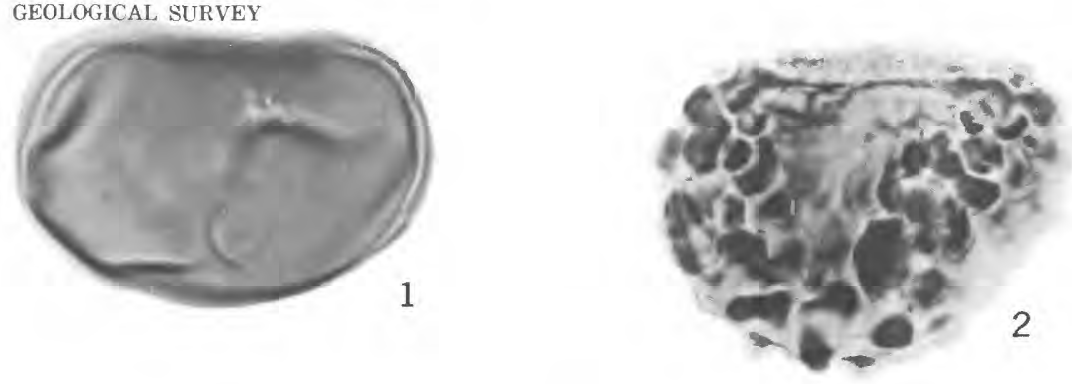

PROFESSIONAL PAPER 1084-PLATE 1
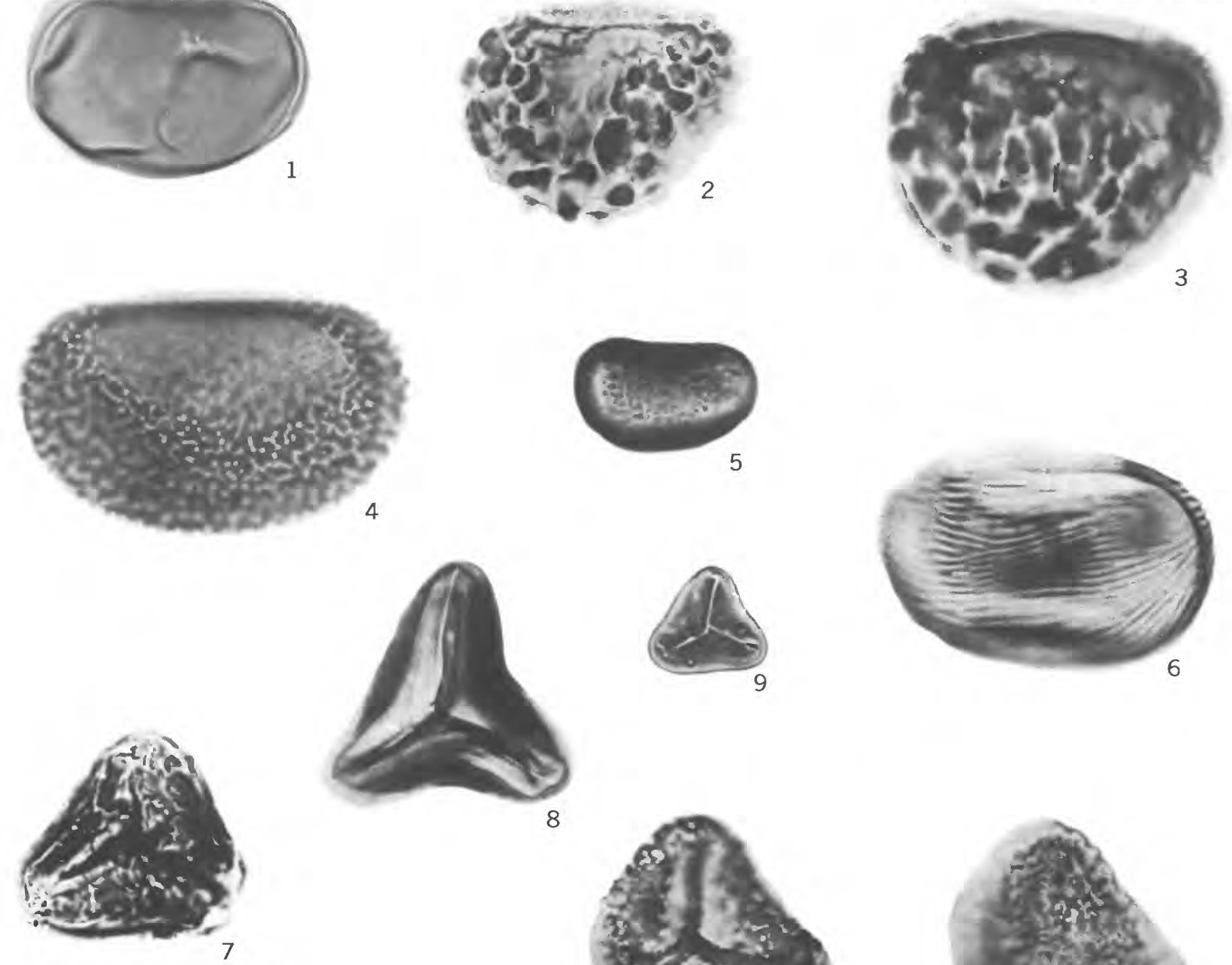

8
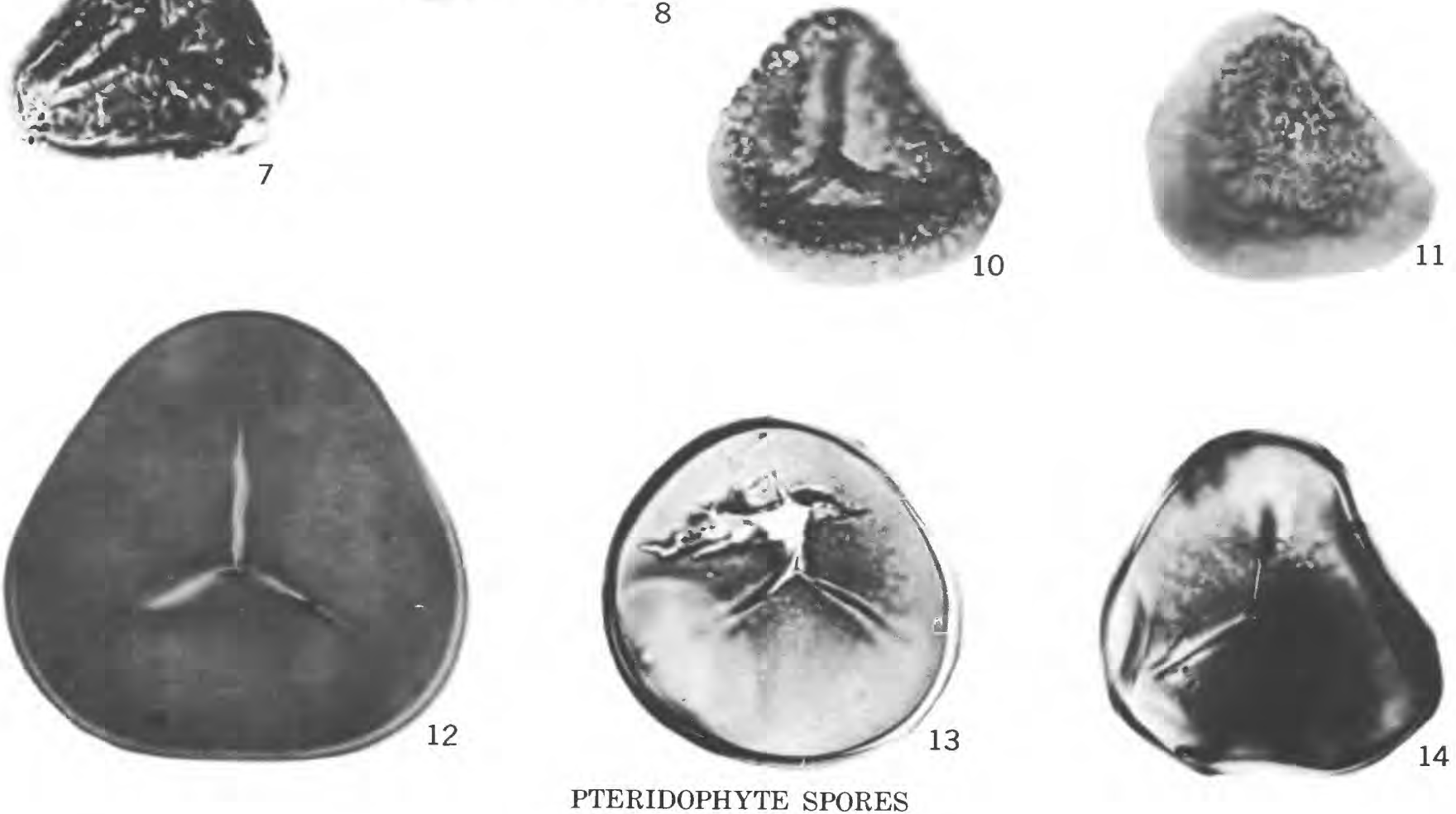

PTERIDOPHYTE SPORES 


\title{
PLATE 2
}

\author{
[Magnification $\times 1,000]$
}

FIGURE 1. Toroisporis aneddenii (p. 30)

Slide $10556 \mathrm{~A}-1$, coordinates $25.8 \times 115.9$.

2-3. Toroisporis longitora (p. 30).

2. A specimen having slight thickenings of the exine at the corners. Slide $10620 \mathrm{~A}-1$, coordinates $16.5 \times 110.0$.

3. Slide $10627 \mathrm{~A}-1$, coordinates $30.7 \times 116.3$.

4. Toroisporis postregularis (p. 30).

Slide 10696 A-1, coordinates $35.1 \times 112.0$.

5. Ctenopteris? elsikìi (p. 31).

Holotype. Slide $10529 \mathrm{~A}-1$, coordinates $31.3 \times 111.7$.

6. Undulatisporites concavus (p. 31).

Slide 10620 A-1, coordinates $18.7 \times 121.7$.

7. Undulatisporites sp. (p. 31).

Slide $10680 \mathrm{~A}-1$, coordinates $17.9 \times 109.5$.

8. Monoleiotriletes sp. (p. 31).

Slide 10649 A-1, coordinates $26.0 \times 111.0$.

9. Punctatisporites microadriennis (p. 31).

Slide 10680 A-1, coordinates $31.7 \times 111.7$.

10. Osmunda primaria (p. 31).

Slide 10649 A-1, coordinates $26.0 \times 116.0$.

11-12. Bullasporis sp. (p. 32).

11. Slide $10696 \mathrm{~A}-1$, coordinates $17.8 \times \mathbf{1 1 9 . 5}$.

12. Slide $10649 \mathrm{~A}-1$, coordinates $25.9 \times 114.1$.

13. Granulatisporites luteticus (p. 31).

Slide 10864 A-2, coordinates $31.0 \times 126.0$. 



\section{PLATE 3}

1. Cicatricosisporites dorogensis (p. 32).

Slide 10637 A-1, coordinates $40.9 \times 124.7$.

2-3. Cicatricosisporites embryonalis (p. 32).

Slide $10676 \mathrm{~A}-1$, coordinates $28.3 \times 121.2$.

4. Cicatricosisporites paradorogensis (p. 32).

Slide 10663 A-1, coordinates $25.1 \times 119.5$.

5-6. Pteris dentata (p. 32).

Slide 10678 A-2, coordinates $22.5 \times 114.0$.

7-8. Lycopodium convexum (p. 32).

Holotype. Slide 10650 A-2, coordinates $27.8 \times 113.0$.

9-10. Lycopodium hamulatum (p. 32).

Slide $10556 \mathrm{~A}-1$, coordinates $44.1 \times 115.7$.

11. Lycopodium venustum (p. 33).

Holotype. Slide 10620 A-1, coordinates $25.5 \times 118.5$.

12-13. Lycopodium heskemensis (p. 33).

Slide $10663 \mathrm{~A}-1$, coordinates $21.4 \times 124.2$.

14-15. Selaginella perinata (p. 33).

Slide $10657 \mathrm{~A}-1$, coordinates $25.0 \times 115.9$. 
GEOLOGICAL SURVEY

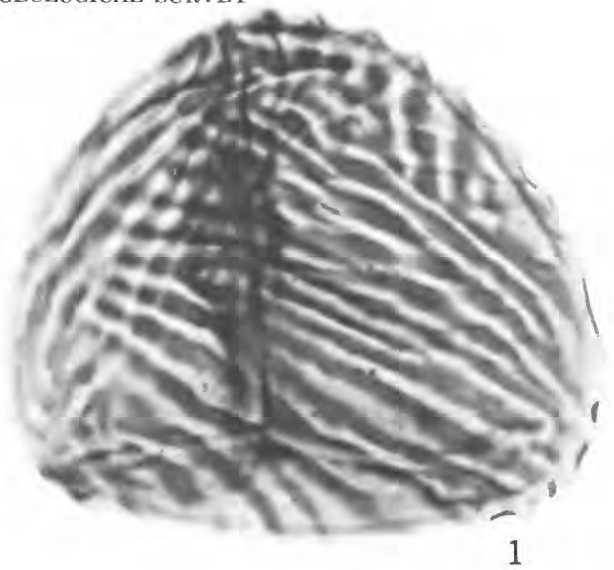

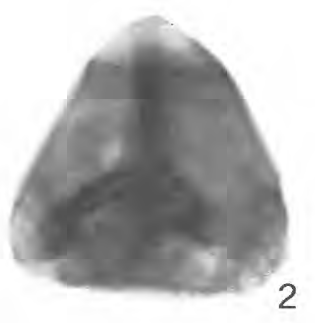
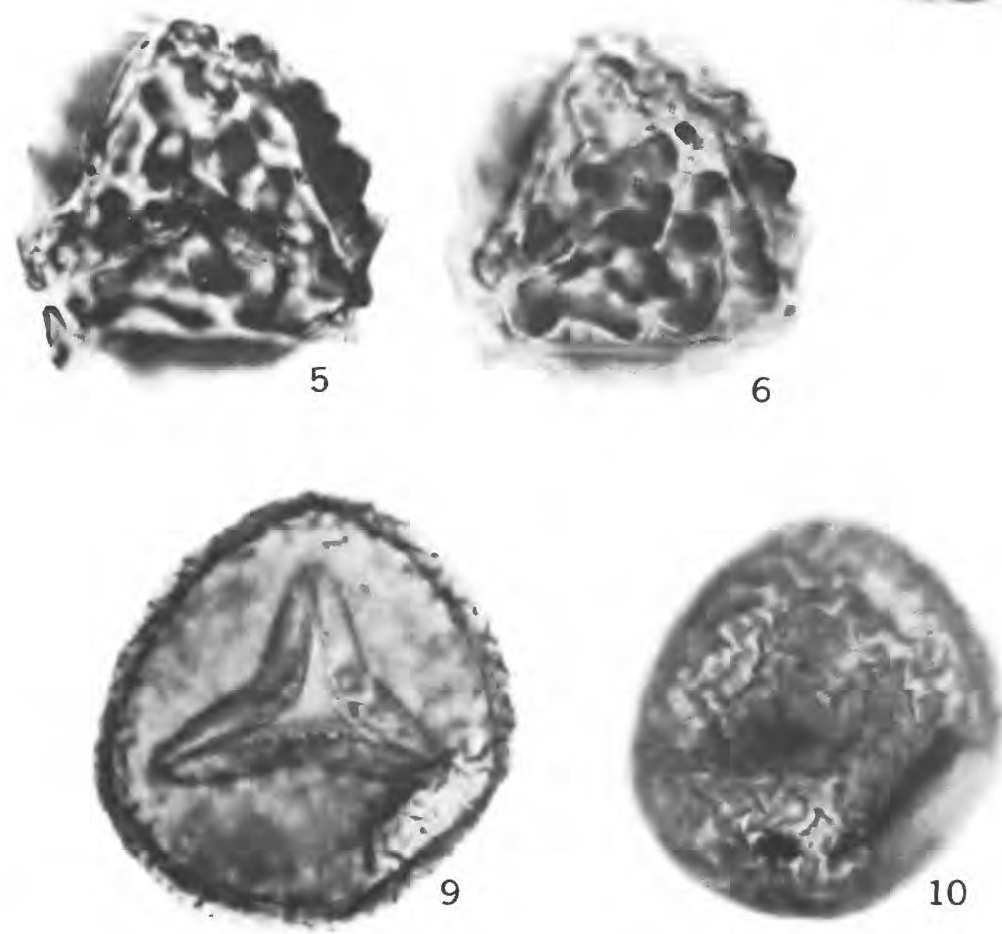

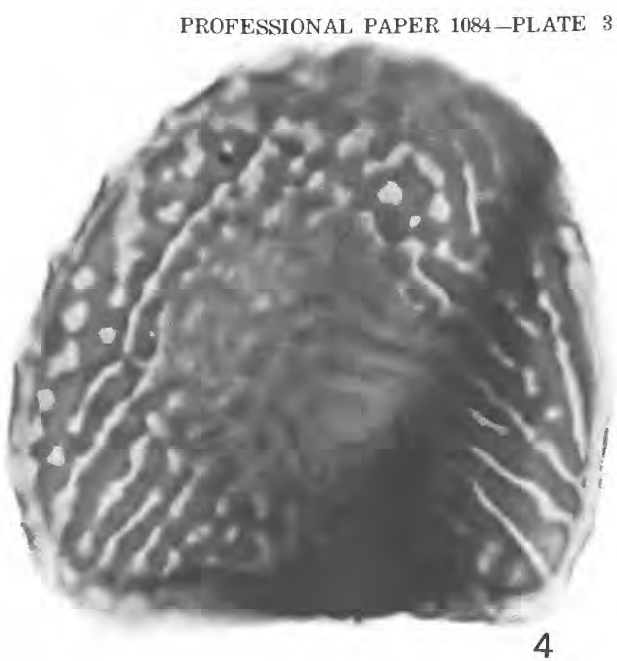

3
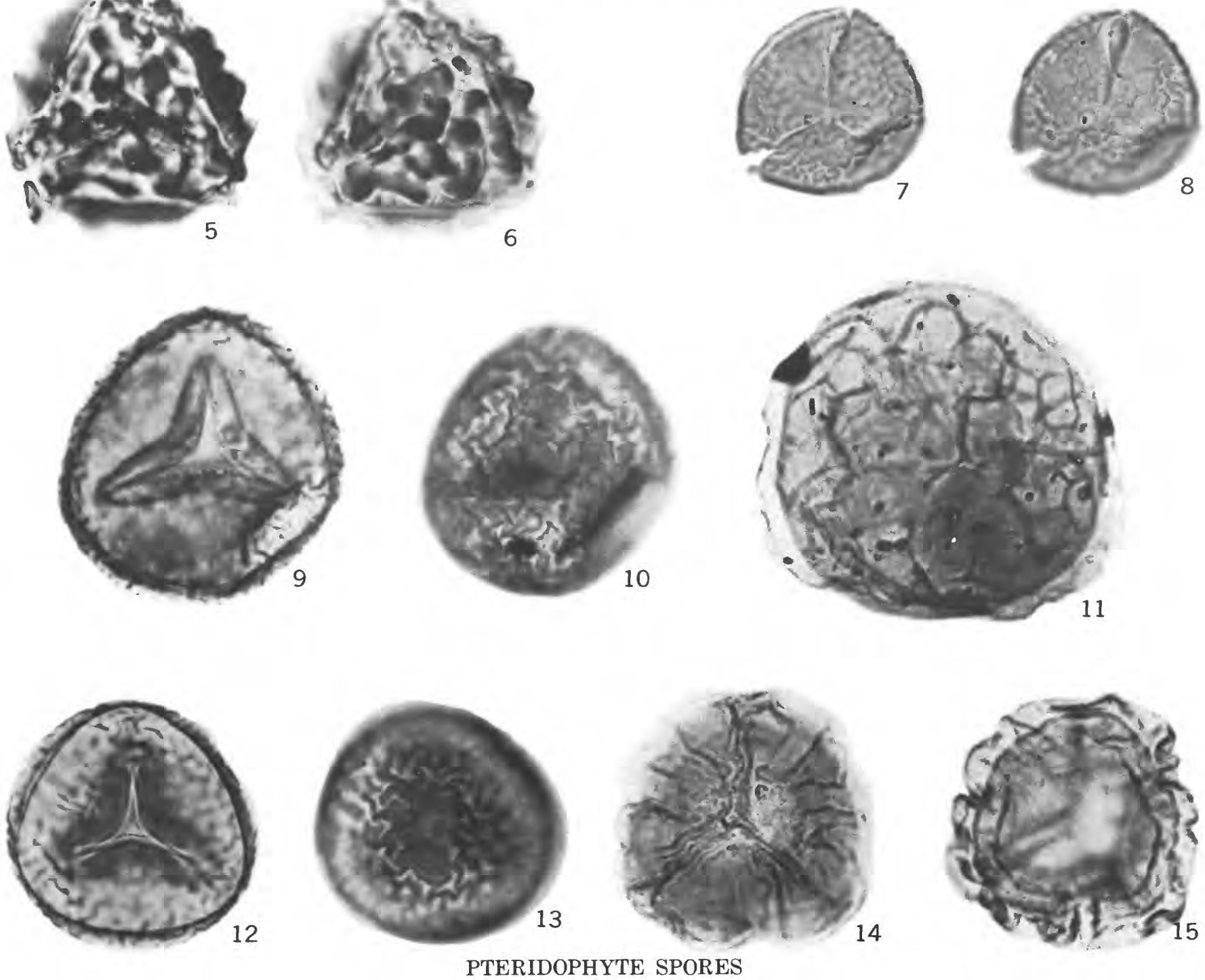

PTERIDOPHYTE SPORES

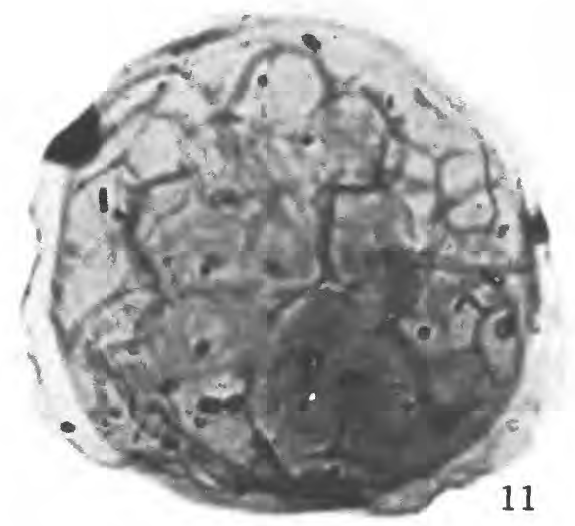


PLATE 4

[Magnification $\times 1,000$ ]

FiguRE 1. St.ereisporites megastereoides (p. 34).

Slide 10864 A-2, coordinates $14.3 \times 123.6$.

2-6. Selaginella sp. A (p. 33).

2-3. Slide $10678 \mathrm{~A}-2$, coordinates $18.3 \times 120.9$.

4-5. Slide $10676 \mathrm{~A}-1$, coordinates $25.7 \times 124.6$.

6. Slide 10557 A-2, coordinates $40.2 \times 123.6$.

7-10. Selaginella sp. B (p. 33).

7-8. Slide 10864 A-2, coordinates $32.6 \times 115.7$.

9-10. Slide 10864 A-2, coordinates $35.2 \times 109.9$.

11. Sphagnum antiquasporites (p. 34).

Slide 10512 C-2, coordinates $35.0 \times 118.0$.

12. Sphagnum australum (p. 34).

Slide 10864 A-2, coordinates $13.8 \times 113.0$.

13. Sphagnum stereoides (p. 34).

Slide 10620 A-1, coordinates $15.5 \times 122.1$.

14. Sphagnum triangularum (p. 34).

Slide 10680 A-1, coordinates $29.7 \times 119.0$.

15. Stereisporites woelfersheimensis (p. 34).

Slide 10656 A-2, coordinates $32.7 \times 110.2$.

16. Podocarpus maximus (p. 35).

Slide $10696 \mathrm{~A}-1$, coordinates $24.3 \times 118.1$.

17-18. Podocarpus? cappulatus (p. 34).

17. Slide $10556 \mathrm{~A}-1$, coordinates $44.7 \times 124.1$.

18. Slide 10864 A-2, coordinates $28.8 \times 123.1$. 

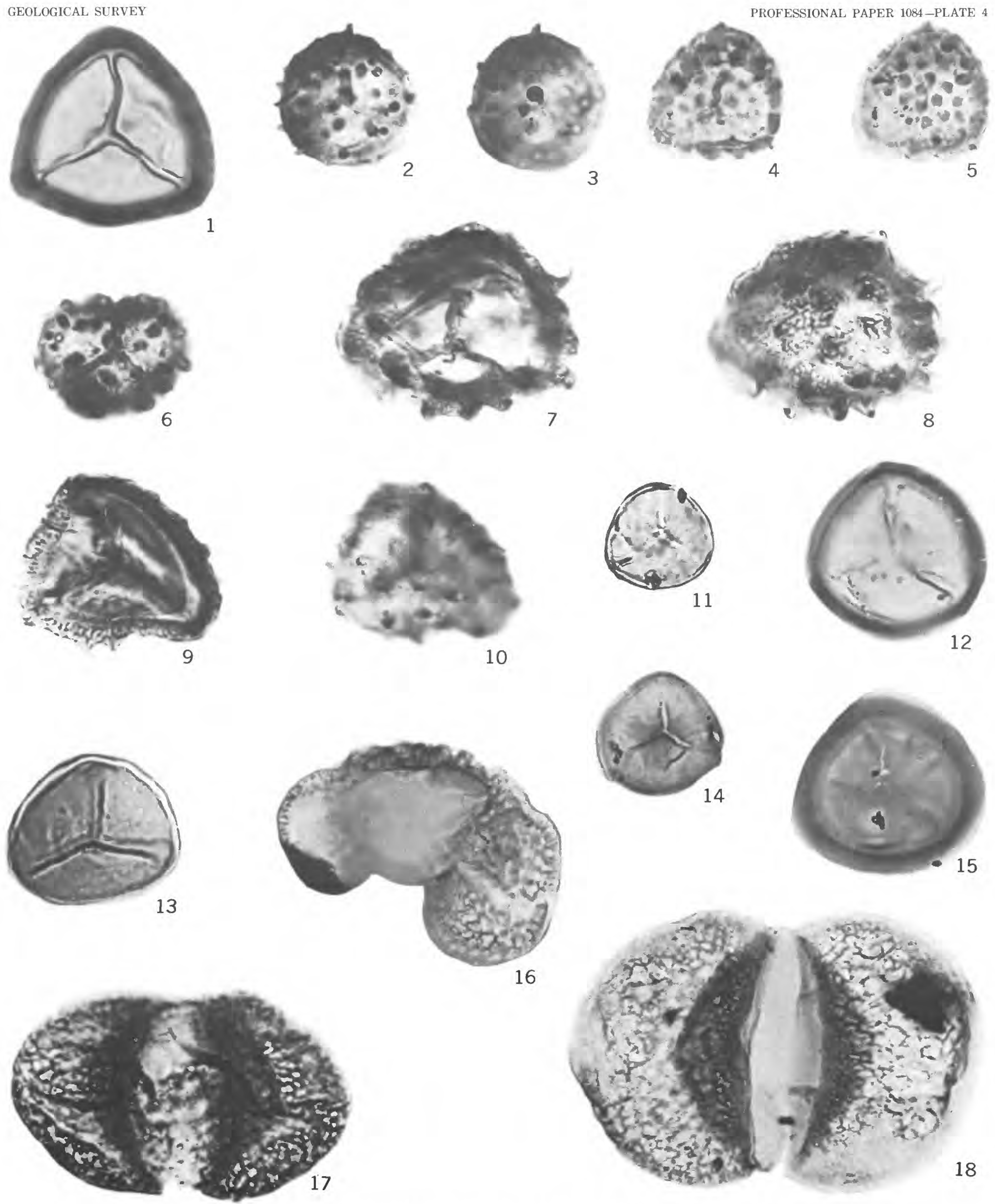

16

BRYOPHYTE AND PTERIDOPHYTE SPORES AND GYMNOSPERM POLLEN GRAINS 


\section{PLATE 5}

[Magnification $\times 1,000$ ]

FIGUREs 1-2. Pityosporites longifoliaformis (p. 35).

1. Slide $10680 \mathrm{~A}-1$, coordinates $31.2 \times 113.0$.

2. Slide $10663 \mathrm{~A}-1$, coordinates $20.0 \times 115.6$.

3-4. Pinus cembraeformis (p. 35).

Slide 10553 A-1, coordinates $45.5 \times 120.5$.

5. Pinus tenuextima (p. 36).

Slide 10863 A-2, coordinates $25.0 \times 112.9$.

6. Pinus labdaca (p. 35).

Slide 10637 A-2, coordinates $43.8 \times 125.0$.

7. Picea grandivescipites (p. 36).

Slide 10680 A-1, coordinates $29.6 \times 123.1$. 

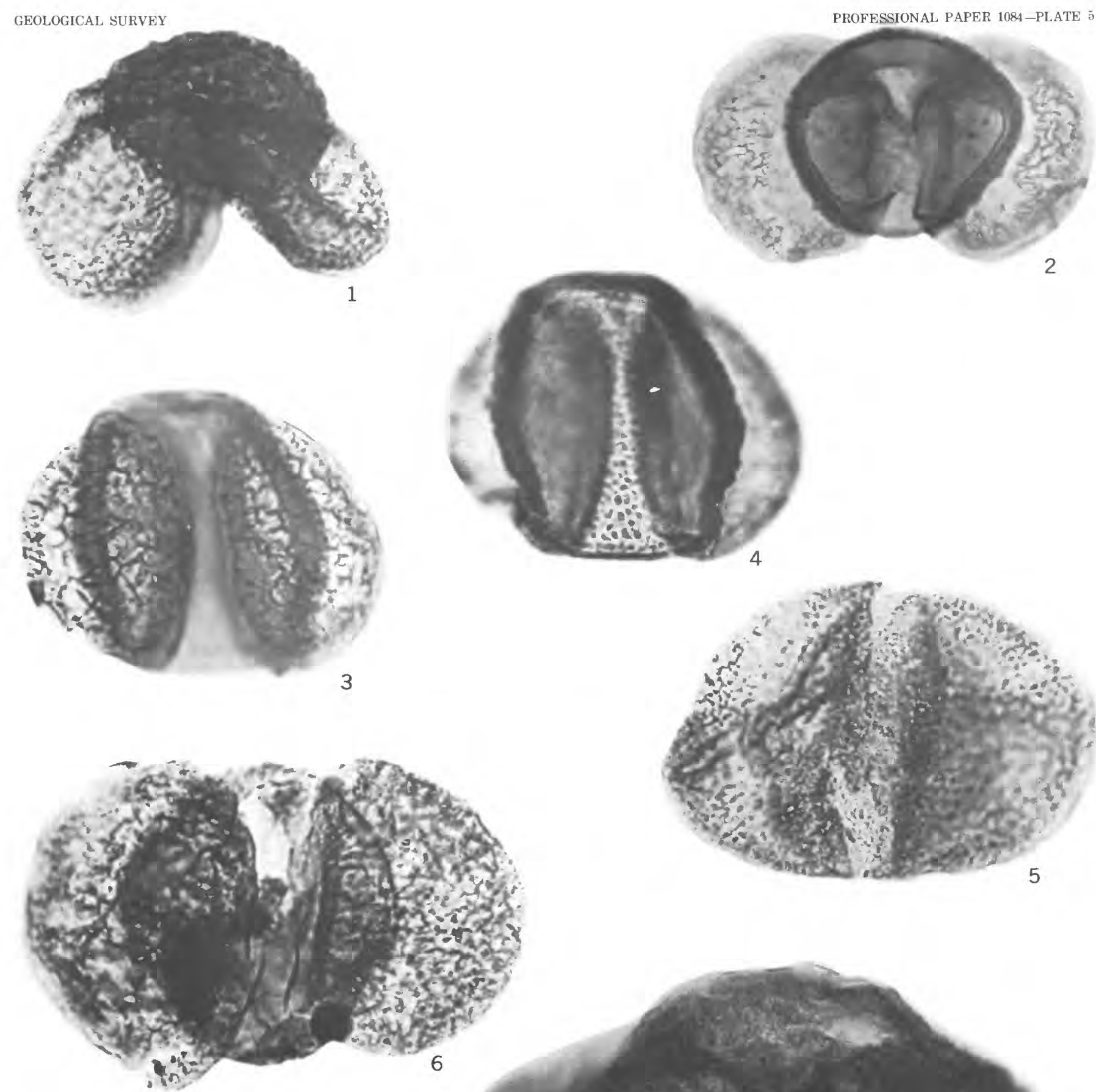


\section{PLATE 6}

[Magnification $\times 1,000]$

FIGURE 1. Picea grandivescipites (p. 36).

Slide 10529 A-1, coordinates $32.6 \times 112.1$.

2-3. Cedrus piniformis (p. 36).

2. Slide $10863 \mathrm{~A}-2$, coordinates $31.7 \times 115.2$.

3. Slide $10696 \mathrm{~A}-1$, coordinates $21.0 \times 120.8$.

4-5. Tsuga ignicula (p. 36).

Slide $10653 \mathrm{~A}-1$, coordinates $29.7 \times 118.0$.

6. Cupressacites hiatipites (p. 36).

Slide 10864 A-3, coordinates $17.8 \times 120.1$.

7. Sequoiapollenites lapillipites (p. 36).

Slide 10529 A-1, coordinates $25.4 \times 115.8$. 

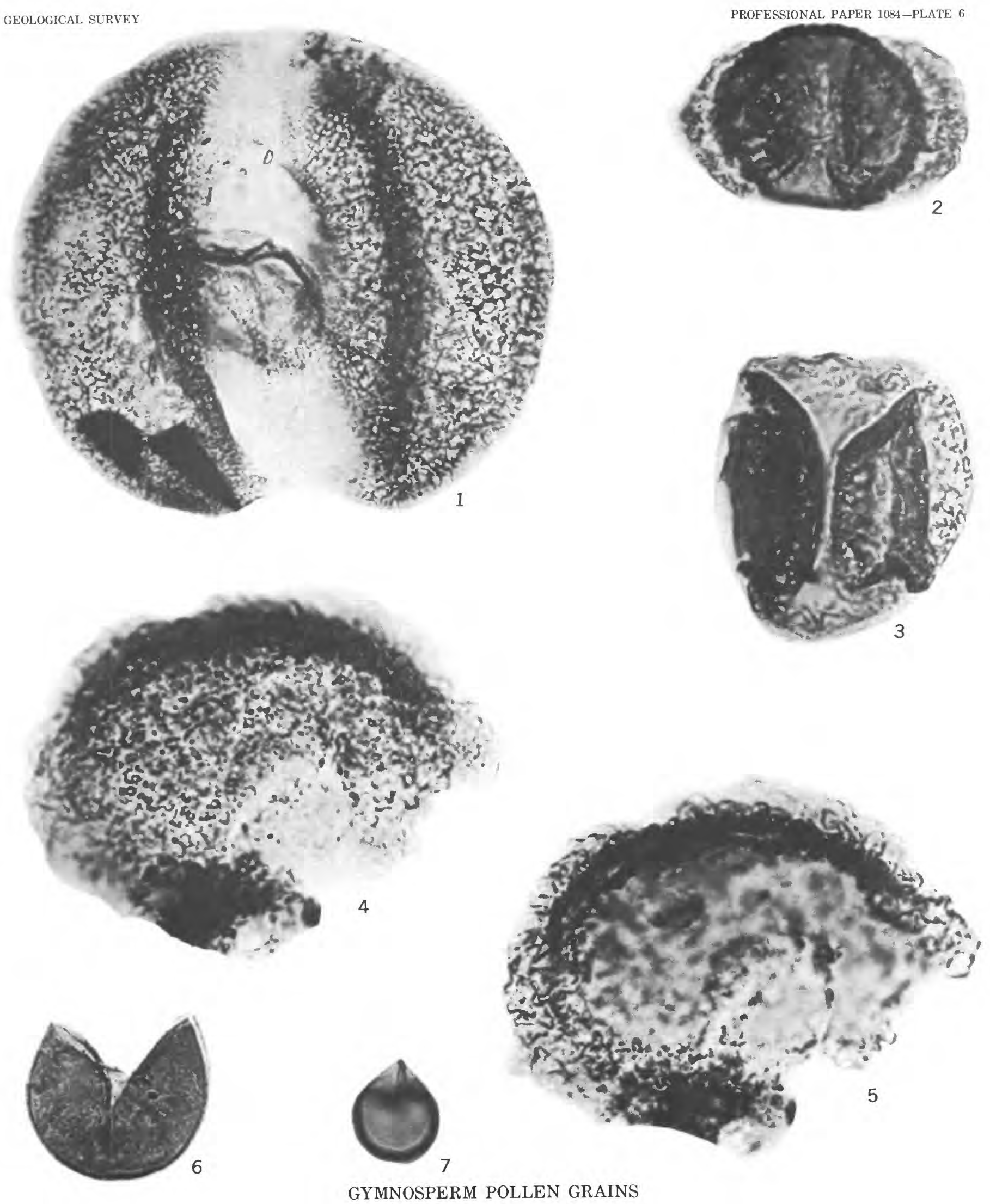


\section{PLATE 7}

[Magnification $\times 1,000$ ]

Figure 1. Ephedra exiguua n. sp. (p. 37). Holotype.

Slide 10556 A-1, coordinates $25.3 \times 113.6$.

2-3. Ephedra claricristata (p. 36).

Slide $10637 \mathrm{~A}-1$, coordinates $27.4 \times 126.7$.

4. Ephedra hungarica (p. 37).

Slide 10627 A-2, coordinates $22.8 \times 116.4$.

5. Ephedra? laevigataeformis (p. 37).

Slide $10653 \mathrm{~A}-1$, coordinates $13.6 \times 118.9$.

6. Graminidites gramineoides (p. 37).

Slide 10643 A-1, coordinates $31.1 \times 118.2$

7. Milfordia incerta (p. 38).

Slide 10557 A-2, coordinates $22.6 \times 118.9$.

8. Milfordia minima (p. 38).

Slide $10545 \mathrm{~A}-1$, coordinates $23.7 \times 113.6$.

9-10. Aglaoreidia cyclops (p. 38).

Slide $10556 \mathrm{~A}-1$, coordinates $22.5 \times 113.6$.

11. Aglaoreidia pristina (p. 38).

Slide 10529 A-1, coordinates $28.9 \times 126.0$.

12-14. Momipites coryloides (p. 38).

12. Slide $10864 \mathrm{~A}-3$, coordinates $18.0 \times 113.7$.

13. A specimen having two cracks or tears of the exine, superficially like pseudocolpi. Slide 14962 B-1, coordinates $31.3 \times 115.3$.

14. A specimen in which the fold is bordered by a white streak, superficially like a pseudocolpus. Slide 10639 A-2, coordinates $34.4 \times 110.8$.

15-16. Momipites microfoveolatus (p. 39).

15. Slide $10557 \mathrm{~A}-2$, coordinates $37.0 \times 115.4$.

16. Slide $10672 \mathrm{~A}-2$, coordinates $35.1 \times 116.3$.

17. Platycarya sp. (p. 39).

Slide $14959 \mathrm{~A}-1$, coordinates $40.8 \times 124.8$.

18-19. Triporopollenites? maternus (p. 39)

Slide $10556 \mathrm{~A}-1$, coordinates $33.2 \times 116.1$.

20. Ludwigia oculus-noctis (p. 39).

Slide $10863 \mathrm{~A}-2$, coordinates $22.1 \times 127.1$.

21-22. Proteacidites? laxus (p. 40).

Holotype. Slide 10637 A-2, coordinates $25.0 \times 114.8$.

23. Triatriopollenites proprius (p. 40).

Holotype. Slide 10531 A-1, coordinates $27.2 \times 127.3$.

24. Casuarinidites discrepans (p. 40).

Holotype. Slide 10690 A-1, coordinates $24.3 \times 113.6$.

25-27. Casuarinidites cf. C. granilabratus (p. 40).

25. Slide $10545 \mathrm{~A}-1$, coordinates $34.6 \times 121.0$.

26. Slide $10692 \mathrm{~A}-2$, coordinates $22.3 \times 109.5$.

27. Slide $10692 \mathrm{~A}-2$, coordinates $34.0 \times 121.3$. 

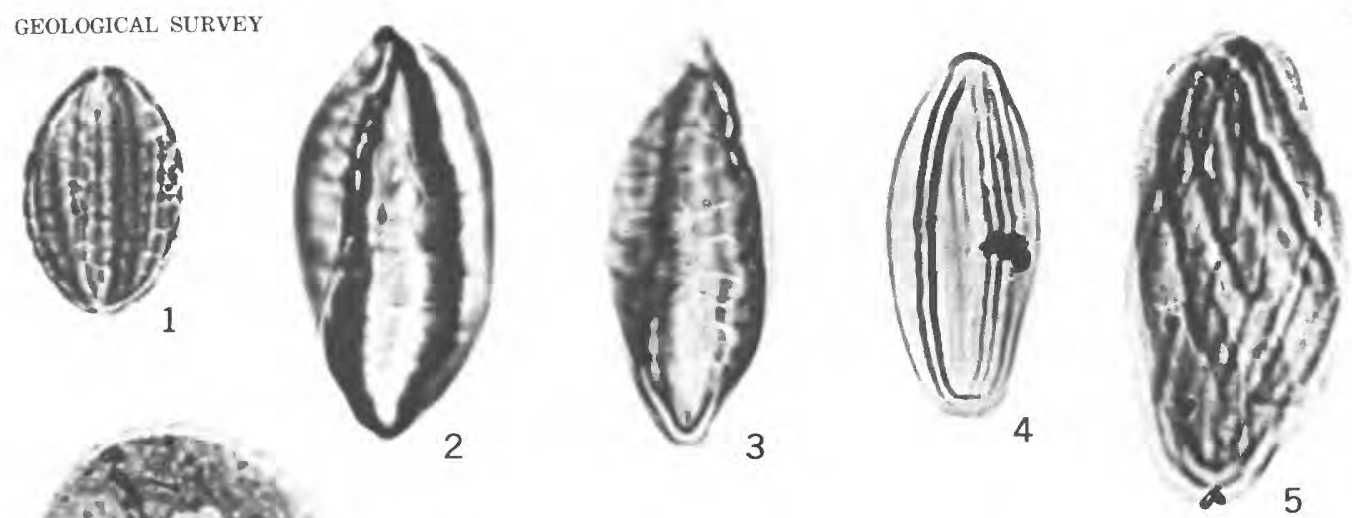

PROFESSIONAL PAPER 1084-PLATE 7
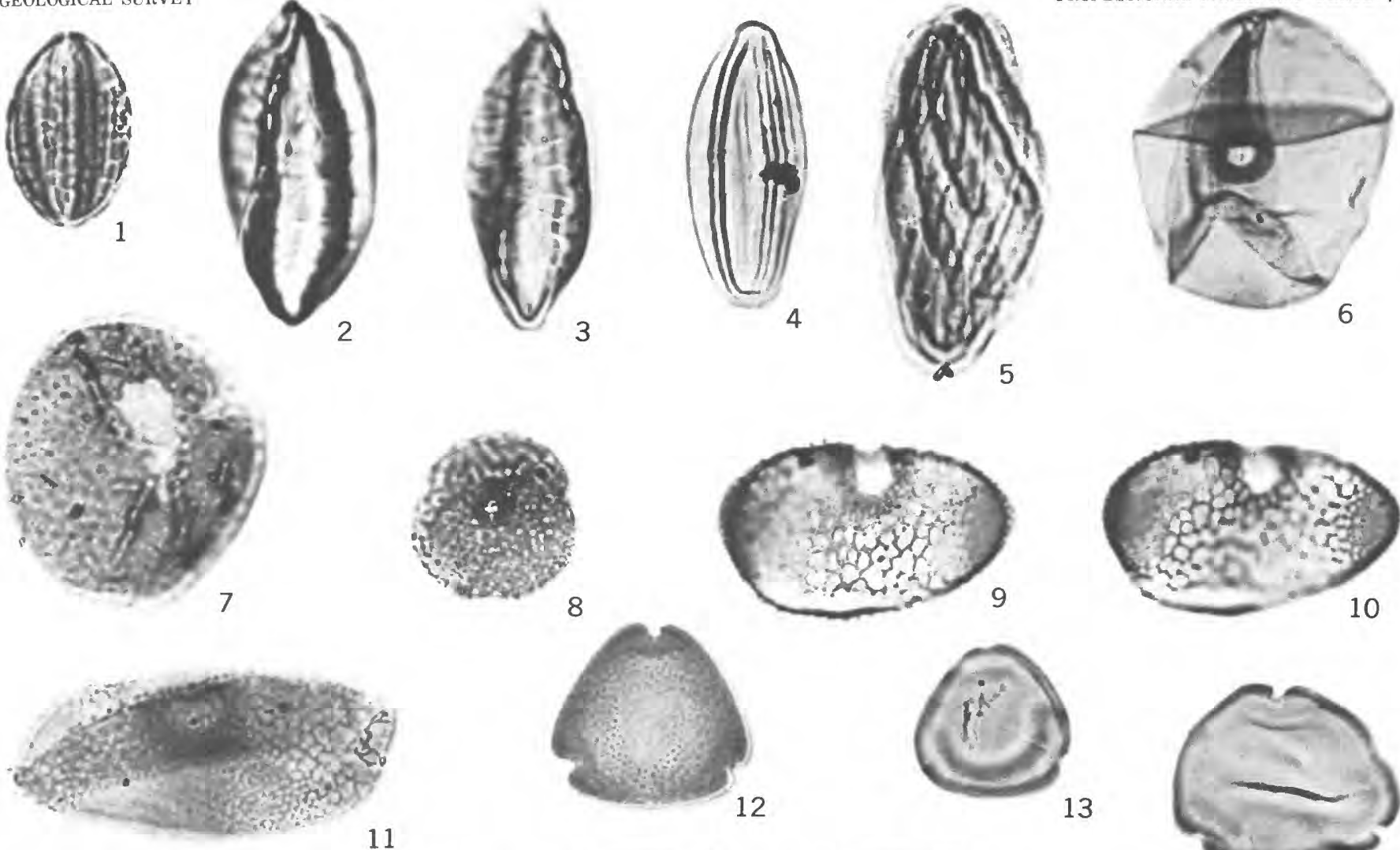

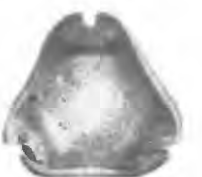

15

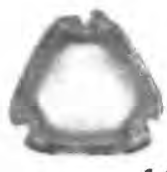

16

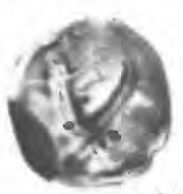

17

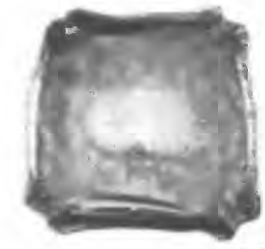

18

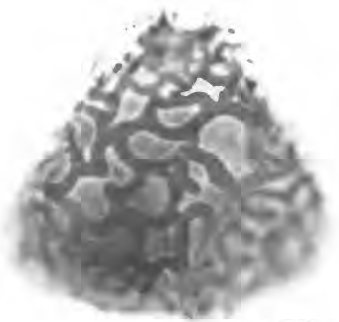

21

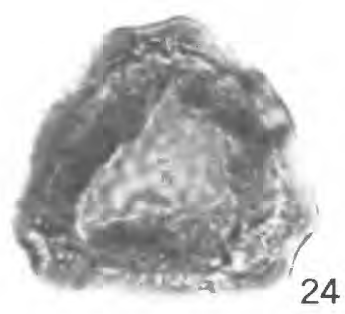

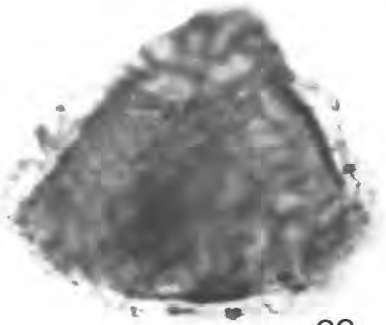

22
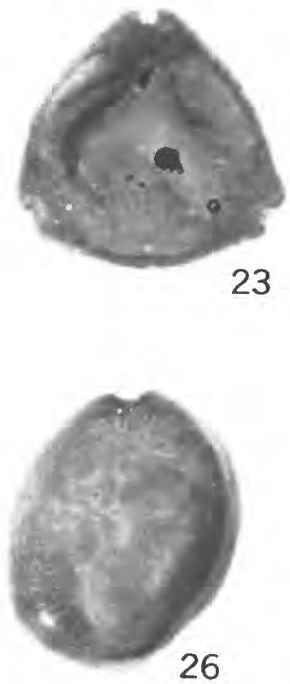

23

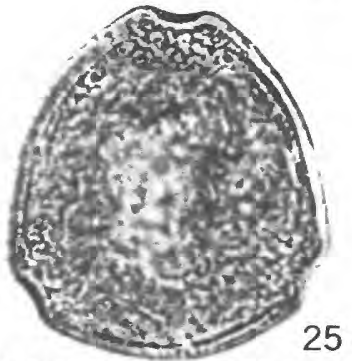

GYMNOSPERM AND ANGIOSPERM POLLEN GRAINS
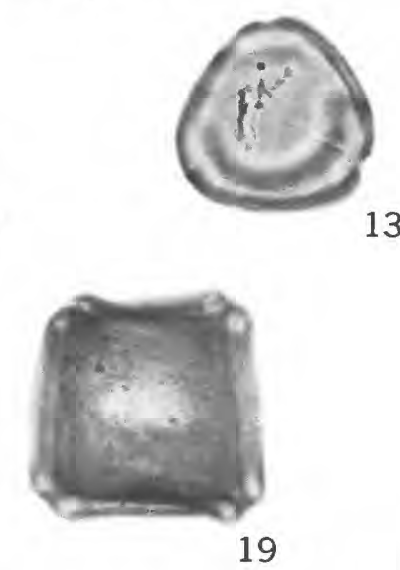

13
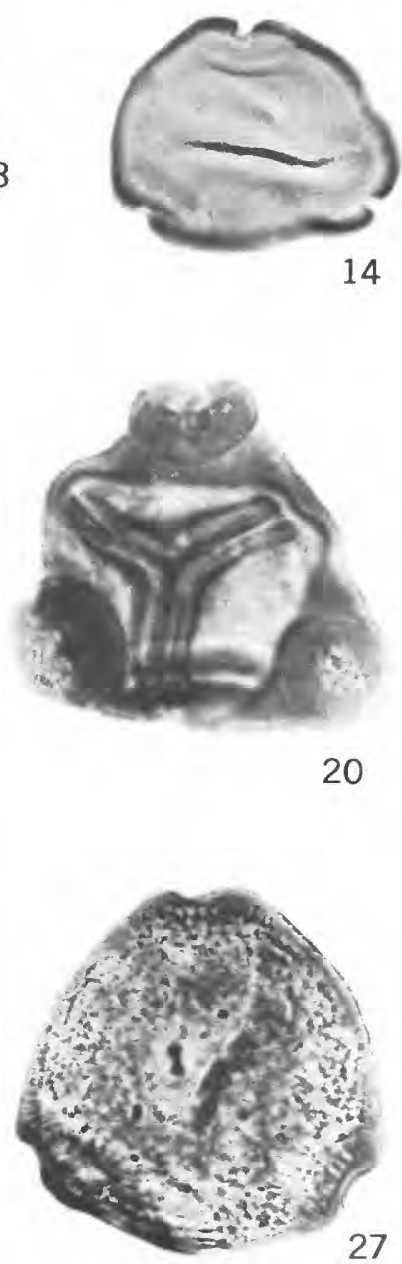


\section{PLATE 8}

[Magnification $\times 1,000$ ]

FIGURES 1-2. Triatriopollenites? aff. T. aroboratus (p. 40).

1. Slide $10555 \mathrm{~A}-1$, coordinates $34.3 \times 119.7$.

2. Slide $10557 \mathrm{~A}-2$, coordinates $36.8 \times 126.3$.

3. Trivestibulopollenites engelhardtii (p. 41).

Holotype. Slide 10637 A-2, coordinates $40.1 \times 113.4$.

4. Betula? sp. (p. 41).

Slide 10529 A-1, coordinates $21.7 \times 112.0$.

5. Plicapollis spatiosa (p. 41).

Holotype. Slide 10863 A-2, coordinates $38.7 \times 118.0$.

6. Thomsonipollis magnifizca (p. 41).

Slide 10656 A-2, coordinates $21.8 \times 121.8$.

7. Carya simplex (p. 42).

Slide 10534 A-1, coordinates $19.5 \times 112.0$.

8. Carya veripites (p. 42).

Slide 10863 A-2, coordinates $40.0 \times 119.0$

9-10. Alnus vera (p. 42).

9. Slide $10557 \mathrm{~A}-2$, coordinates $22.2 \times 117.2$.

10. Slide 10557 A-2, coordinates $22.9 \times 126.1$.

11-12. Planera? thompsoniana (p. 42).

11. Slide 10531 A-1, coordinates $19.4 \times 126.3$.

12. Slide 10435 A-1, coordinates $38.2 \times 122.4$.

13-14. Myriophyllum sp. (p. 42).

Slide 10649 A-1, coordinates $25.8 \times 119.4$.

15. Pterocarya stellata (p. 43).

Slide $10620 \mathrm{~A}-1$, coordinates $25.0 \times 110.5$.

16-17. Juglans nigripites (p. 43).

Slide 10627 A-2, coordinates $23.3 \times 124.3$.

18-19. Juglanspollenites infrabaculatus ( $p .43$ ).

Holotype. Slide 10558 A-1, coordinates $26.9 \times 121.1$.

20. Anacolosidites sp. (p. 44).

Slide 14965 A-1, coordinates $39.8 \times 119.6$.

21-22. Parsonsidites conspicuus (p. 43).

Holotype. Slide 10627 A-2, coordinates $20.9 \times 120.9$.

23-25. Celtis tschudyi (p. 43).

23-24. Slide $14959 \mathrm{~A}-2$, coordinates $28.0 \times 112.8$.

25. Slide $10642 \mathrm{~A}-2$, coordinates $34.3 \times 116.4$.

26. Chenopodipollis sp. (p. 44).

Slide 10553 A-1, coordinates $25.0 \times 120.5$.

27. Malvacipollis tschudyi (p. 44).

Holotype. Slide 10545 A-1, coordinates $34.3 \times 113.2$. 

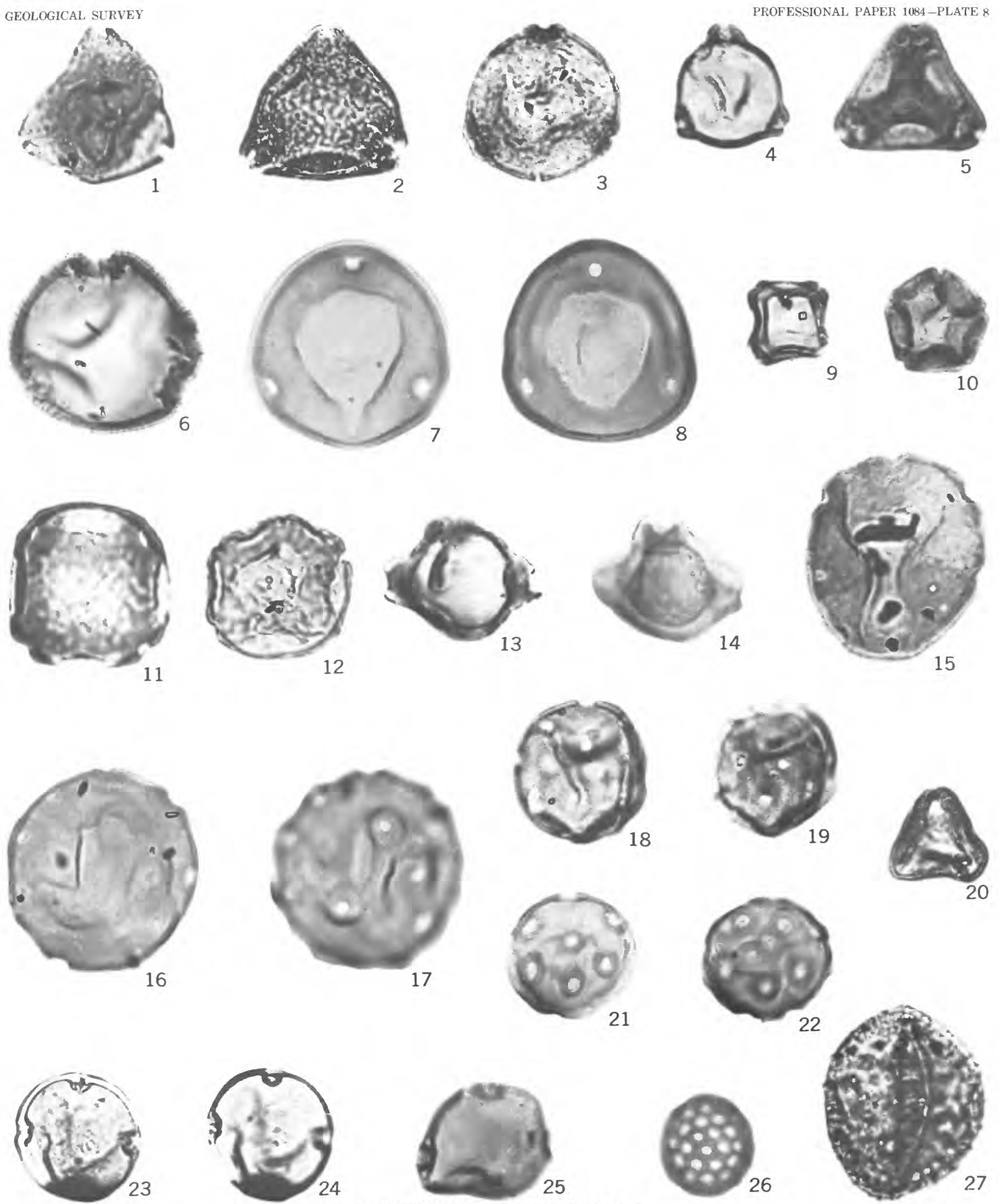

ANGIOSPERM POLLEN GRAINS
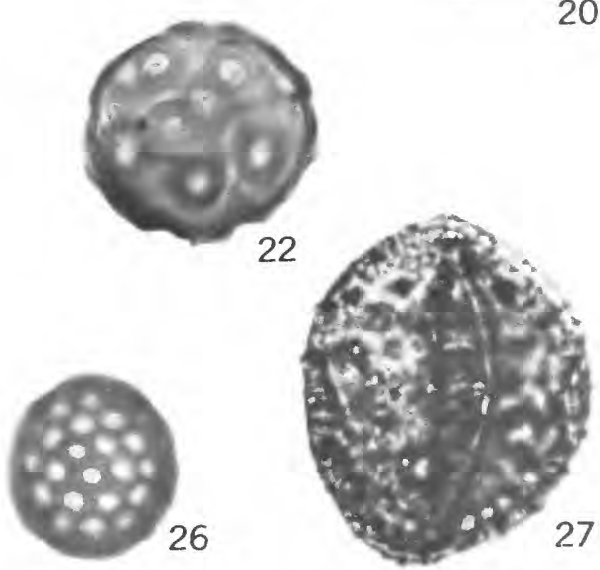


\section{PLATE 9}

[Magnification $\times 1,000$ ]

FIgURes 1-3. Lymingtonia ef. L. rhetor (p. 44).

1-2. Slide $10627 \mathrm{~A}-1$, coordinates $17.5 \times 124.1$.

3. Slide 10863 A-2, coordinates $25.7 \times 115.1$.

4. Monosulcites asymmetricus (p. 44).

Holotype. Slide 10558 A-1, coordinates $43.4 \times 120.5$.

5. Monocolpopollenites tranquillus $(p, 45)$.

Slide 10557 A-2, coordinates $25.0 \times 127.2$.

6-8. Sabal cf. S. granopollenites (p. 45).

6. Slide $10556 \mathrm{~A}-1$, coordinates $23.2 \times 123.2$.

7. Slide 14959 A-2, coordinates $28.3 \times 117.4$.

8. Slide 14959 A-1, coordinates $32.0 \times 120.3$.

9-10,12. Arecipites columellus (p. 45).

9. A specimen with a more broadly oval outline than is typical for the species. Slide $10620 \mathrm{~A}-1$, coordinates $21.0 \times 110.8$.

10. Slide $10558 \mathrm{~A}-1$, coordinates $37.7 \times 124.7$.

12. Slide $10558 \mathrm{~A}-1$, coordinates $37.1 \times 116.9$.

11. Confertisulcites fusiformis (p. 45).

Holotype. Slide 10650 A-2, coordinates $27.1 \times 123.0$.

13. Calamuspollenites eocenicus (p. 46).

Slide 10557 A-2, coordinates $20.4 \times 116.0$.

14-15. Liliacidites tritus (p. 46).

Holotype. Slide 10558 A-1, coordinates $34.6 \times 115.3$.

16-17. Liliacidites vittatus (p. 46).

Holotype. Slide 10627 A-1, coordinates $17.7 \times 109.6$.

18-21. Nypa echinata (p. 46).

18-19. Slide 10672 A-2, coordinates $32.5 \times 118.5$.

20. Slide $10558 \mathrm{~A}-1$, coordinates $34.4 \times 118.8$.

21. Slide $10653 \mathrm{~A}-1$, coordinates $32.8 \times 113.7$.

22. Dicolpopollis sp. (p. 46).

Slide 10558 A-1, coordinates $23.0 \times 113.8$

23. Cupuliferoidaepollenites liblarensis (p. 46).

Slide 10675 A-1, coordinates $31.3 \times 125.6$.

24. Cupuliferoidaepollenites cf. C. liblarensis (p. 47).

Slide 10675 A-1, coordinates $26.0 \times 123.6$.

25-27. Cupuliferoidaepollenites cf. C. selectus (p. 47).

25-26. Slide $10558 \mathrm{~A}-1$, coordinates $43.2 \times 120.4$.

27. Slide 10637 A-2, coordinates $40.1 \times 123.0$.

28-29. Cassia certa (p. 47).

Holotype. Slide 10558 A-1, coordinates $36.2 \times 115.2$. 
GEOLOGICAL SURVEY

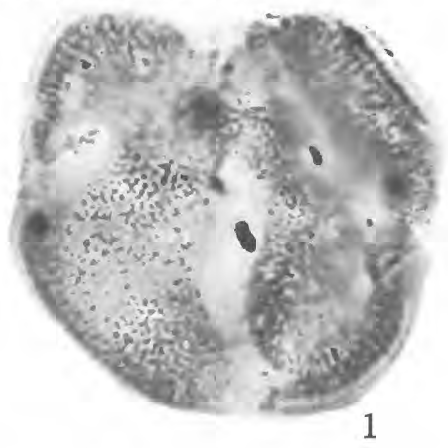

(1)

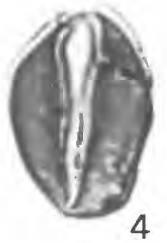

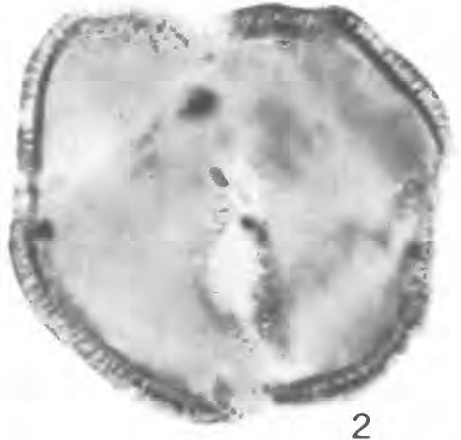
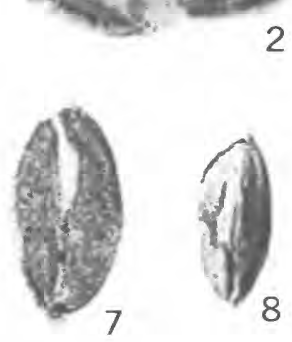
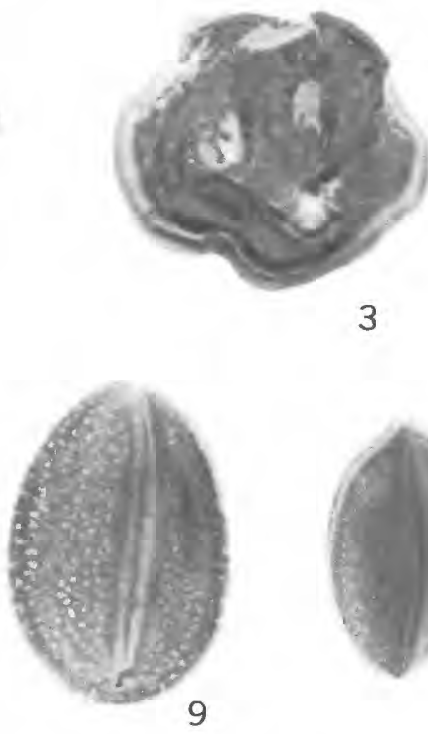

PROFESSIONAL PAPER 1084-PLATE 9
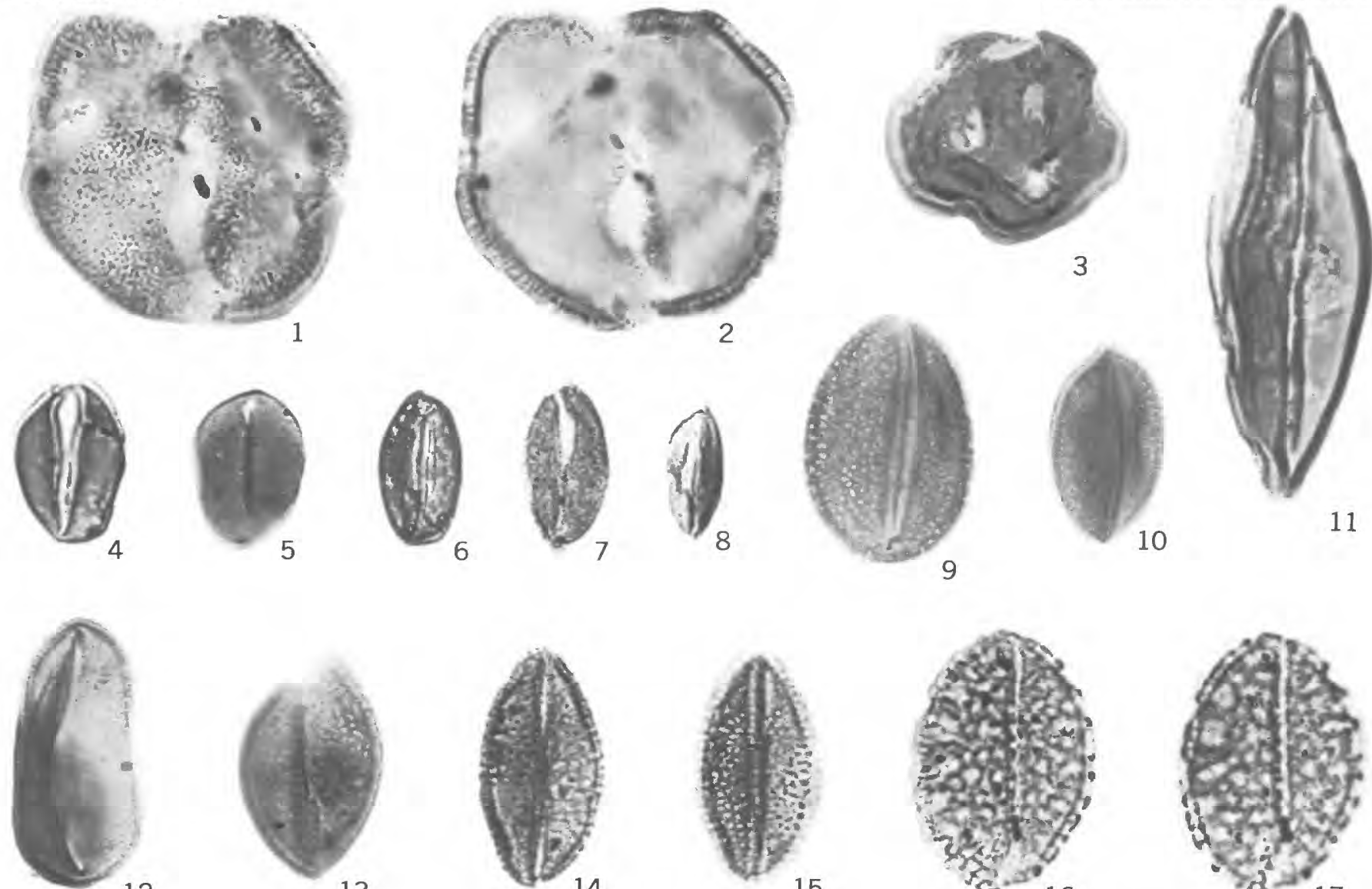

12

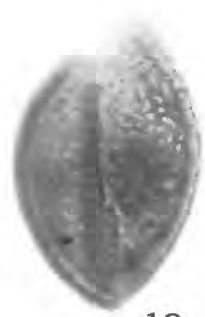

13
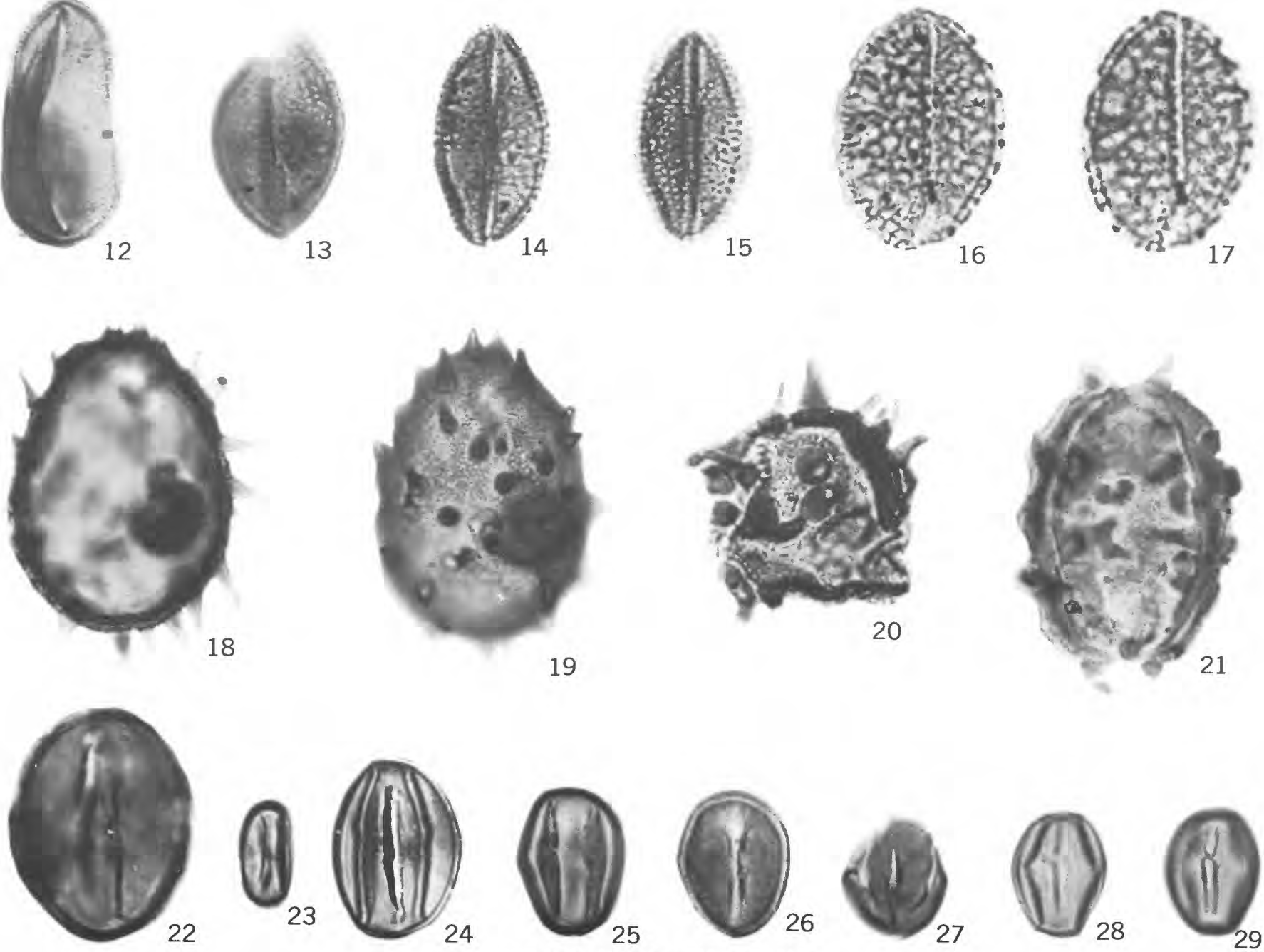
ANGIOSPERM POLLEN GRAINS 


\title{
PLATE 10
}

\author{
[Magnification $\times 1,000]$
}

FIGURES 1-2. Foveotricolpites prolatus (p. 47).

Holotype. Slide $10663 \mathrm{~A}-1$, coordinates $16.2 \times 122.1$.

3-8. Quercoidites inamoenus (p. 47).

$3-4$. A specimen having simple, straight colpi. Slide 10529 A-1, coordinates $33.2 \times 112.4$.

5 -6. A specimen having geniculi. Slide 10627 A-2, coordinates $28.2 \times 120.3$.

7-8. A specimen having slitlike "lolongate ora." Slide $10553 \mathrm{~A}-1$, coordinates $34.1 \times 114.2$.

9-10. Quercoidites microhenricii (p. 47).

9. Slide $10556 \mathrm{~A}-1$, coordinates $24.1 \times 119.9$.

10. Slide $10544 \mathrm{~A}-2$, coordinates $34.1 \times 118.2$.

11-12. Fraxinoipollenites medius (p. 47).

Holotype. Slide $10663 \mathrm{~A}-1$, coordinates $16.9 \times 118.7$.

13. Fraxinoipollenites variabilis (p. 48).

Slide 10637 A-2, coordinates $40.7 \times 122.1$.

14-17. Fraxinoipollenites spp. (p. 48).

14. Slide $10556 \mathrm{~A}-1$, coordinates $24.8 \times 116.7$.

15. Slide $10663 \mathrm{~A}-1$, coordinates $14.5 \times 117.4$.

16-17. Slide $10620 \mathrm{~A}-1$, coordinates $19.1 \times 120.6$.

18. Fraxinoipollenites cf. F. scoticus (p. 48).

Slide 10637 A-2, coordinates $30.0 \times 114.7$.

19. Platanus occidentaloides n. sp. (p. 48).

Holotype. Slide $10558 \mathrm{~A}-1$, coordinates $23.3 \times 122.6$.

20-27. Salixipollenites parvus n. sp. (p. 49).

20-21. Slide $10544 \mathrm{~A}-2$, coordinates $34.2 \times 124.9$.

22-23. Slide 10553 A-1, coordinates $38.9 \times 118.5$.

24-25. Holotype. Slide $10657 \mathrm{~A}-1$, coordinates $31.0 \times 110.9$.

26-27. Slide $10534 \mathrm{~A}-1$, coordinates $25.0 \times 124.4$.

28-32. Fraxinus? pielii n. sp. (p. 49).

28-29. Holotype. Slide $10553 \mathrm{~A}-1$, coordinates $33.2 \times 111.3$.

30. Slide $10627 \mathrm{~A}-2$, coordinates $28.1 \times 126.2$.

31-32. Slide $10558 \mathrm{~A}-1$, coordinates $24.1 \times 122.4$.

33-34. Rousea araneosa (p. 49).

Holotype. Slide $10656 \mathrm{~A}-1$, coordinates $31.9 \times 108.9$.

35-37. Rousea monilifera n. sp. (p. 50).

35. Holotype. Slide 10642 A-2, coordinates $20.0 \times 117.8$.

$36-37$. A specimen having discontinuous muri. Slide $10547 \mathrm{~A}-2$, coordinates $19.1 \times 120.7$. 

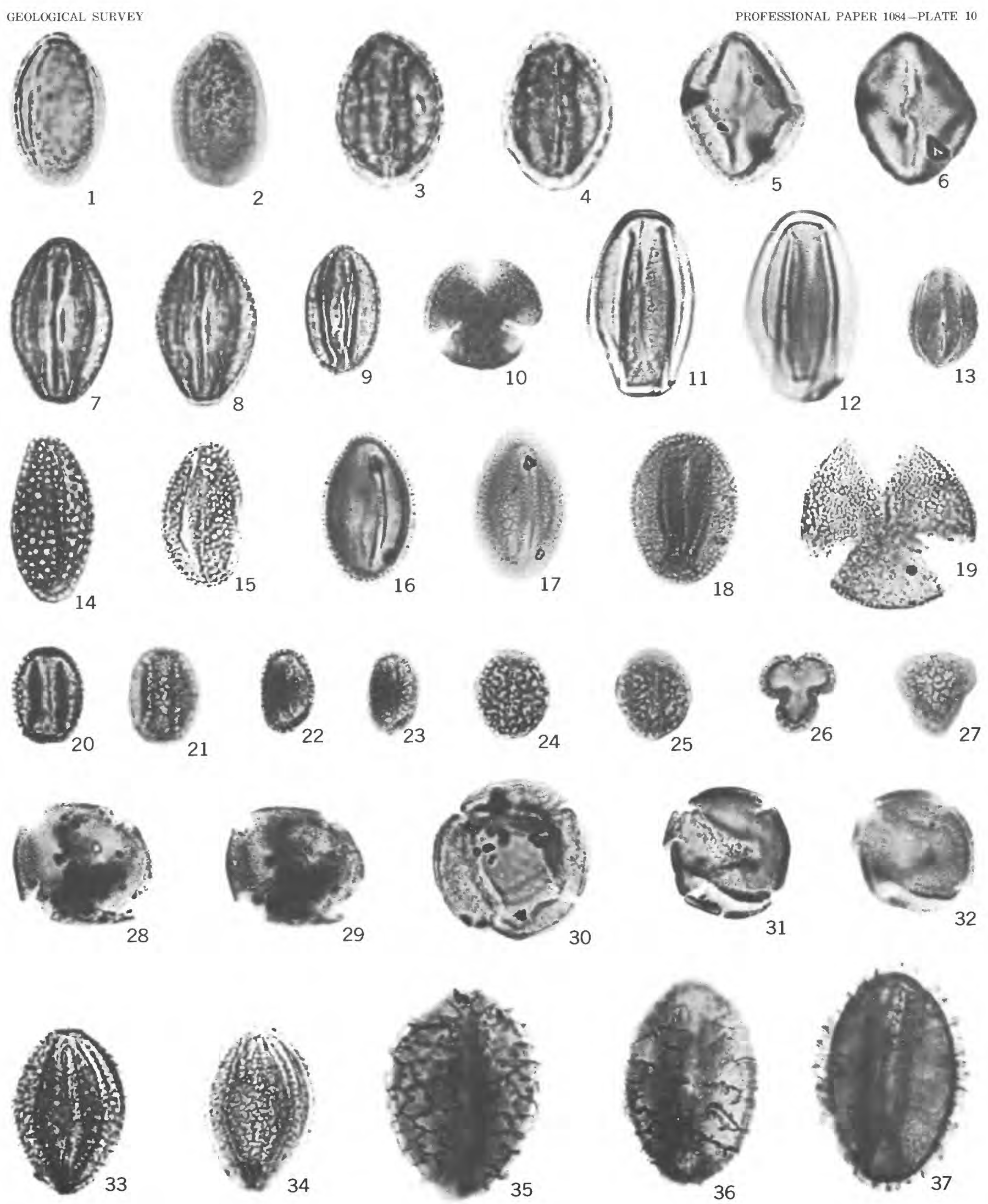

ANGIOSPERM POLLEN GRAINS 


\section{PLATE 11}

[Magnification $\times 1,000$ ]

FIgURES 1-3. Rousea monilifera n. sp. (p. 50).

A specimen having the colpi less deeply invaginated than usual for the species. Slide $10545 \mathrm{~A}-1$, coordinates $36.0 \times 118.5$.

4-5. Acer? striatellum (p. 50).

Slide 10650 A-2, coordinates $25.0 \times 115.0$.

6. Striatopollis terasmaei (p. 50).

Slide 10637 A-2, coordinates $43.1 \times 126.3$.

7-8. Polycolpites sp. (p. 50).

7. Slide 10635 A-2, coordinates $28.8 \times 119.7$.

8. Slide $10637 \mathrm{~A}-1$, coordinates $27.3 \times 123.8$.

9-11. Cupuliferoipollenites spp. (p. 50).

9. Slide $14962 \mathrm{~B}-1$, coordinates $34.0 \times \mathbf{1 1 5 . 5}$.

10. Slide $14960 \mathrm{~A}-1$, coordinates $34.0 \times 113.7$.

11. Slide 10557 A-2, coordinates $25.2 \times 118.6$.

12. Chrysophyllum brevisulcatum (p. 51).

Holotype. Slide 10645 A-2, coordinates $29.6 \times 115.0$.

13-18. Cyrillaceaepollenites kedvesii n. sp. (p. 51).

13-14. Holotype. Slide $10696 \mathrm{~A}-1$, coordinates $35.0 \times 124.6$.

15-16. Slide 10641 A-2, coordinates $21.1 \times 118.4$.

17-18. Slide $10696 \mathrm{~A}-1$, coordinates $27.4 \times 117.0$.

19-22. Cyrillaceaepollenites megaexactus (p. 51).

19. Slide $10637 \mathrm{~A}-1$, coordinates $31.8 \times 121.9$.

20. Slide $10637 \mathrm{~A}-2$, coordinates $39.8 \times 125.2$.

21-22. Slide 10643 A-1, coordinates $22.3 \times 112.9$.

23-24. Cyrillaceaepollenites? ventosus (p. 51).

23. Slide $10653 \mathrm{~A}-1$, coordinates $20.4 \times 125.3$.

24. Slide $10661 \mathrm{~A}-2$, coordinates $29.8 \times 119.6$.

25. Siltaria pacata (p. 52).

Slide 10696 A-1, coordinates $24.2 \times 113.1$.

26-28. Siltaria cf. S. scabriextima (p. 52).

26-27. Slide 10435 A-1, coordinates $32.4 \times 122.0$.

28. Slide $10637 \mathrm{~A}-2$, coordinates $39.9 \times 110.5$.

29-30. Araliaceoipollenites granulatus (p. 52).

Slide 10435 A-1, coordinates $27.7 \times 120.6$.

31-32. Araliaceoipollenites megaporifer n. sp. (p. 52).

Holotype. Slide 10434 A-1, coordinates $41.3 \times 124.7$. 

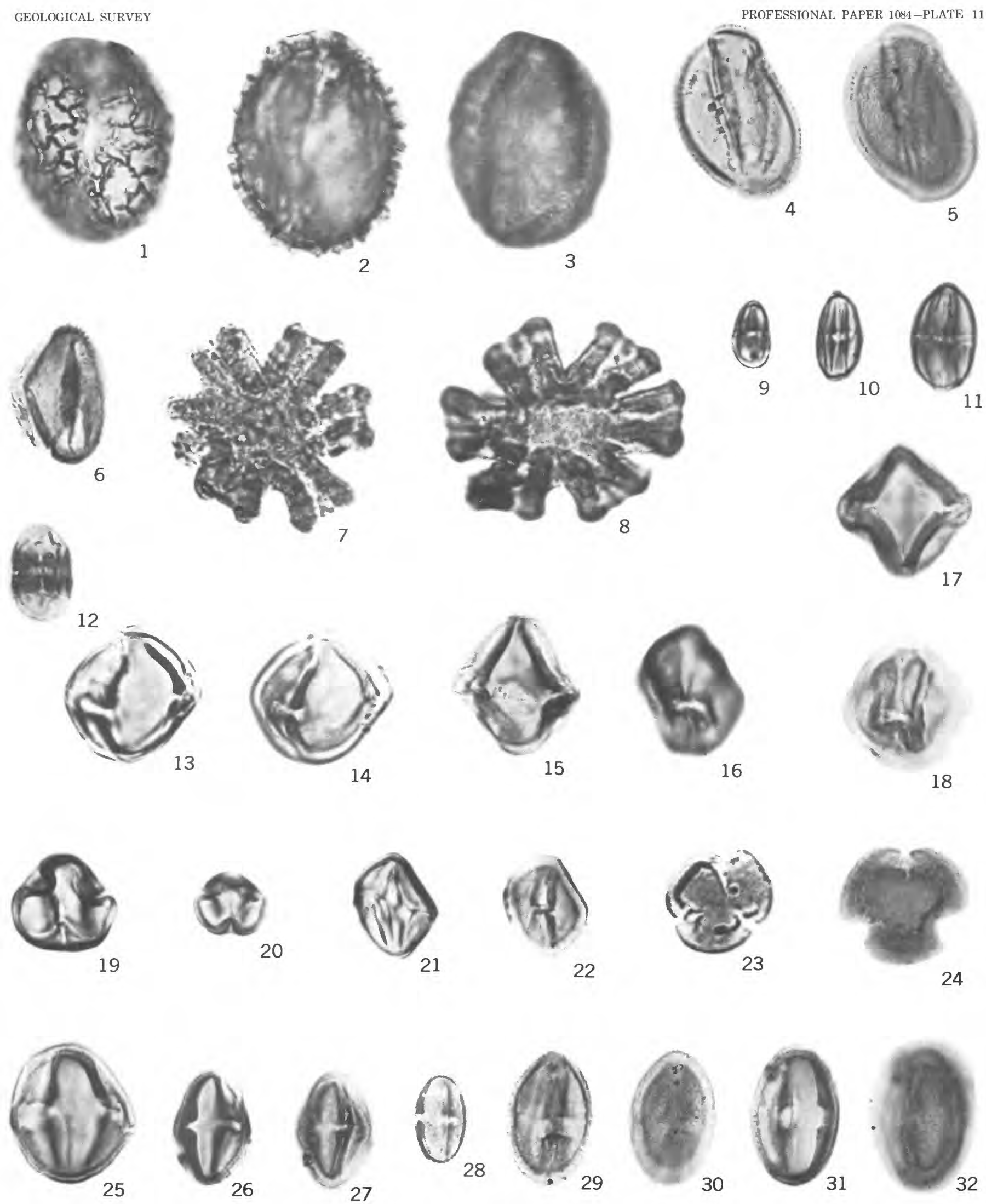

ANGIOSPERM POLLEN GRAINS 
PLATE 12

$[$ Magnification $\times 1,000]$

FIGURE 1. Araliaceoipollenites megaporifer n. sp. (p. 52).

Slide 10637 A-2, coordinates $39.0 \times 126.0$.

2-4. Araliaceoipollenites profundus n. sp. (p. 53).

2. Holotype. Slide 10678 A-2, coordinates $18.0 \times 124.1$.

3-4. A specimen having very deeply invaginated colpi and indistinct ora. Slide $10662 \mathrm{~A}-1$, coordinates $31.4 \times 112.1$.

5-9. Foveotricolporites sp. (p. 53).

5-6. Slide $10625 \mathrm{~A}-1$, coordinates $22.3 \times 116.2$.

7-9. Slide 10627 A-2, coordinates $20.0 \times 114.0$.

10-14. Ilex infissa n. sp. (p. 53).

10-12. Holotype. Slide 10864 A-2, coordinates $23.5 \times 116.9$.

13-14. Slide 10557 A-1, coordinates $34.1 \times 121.3$.

15-16. Ilex media (p. 53).

Slide $10558 \mathrm{~A}-1$, coordinates $35.8 \times 120.8$.

17-19. Vermutricolporites cruciatus n. sp. (p. 54).

17-18. Holotype. Slide 10642 A-2, coordinates $21.4 \times 125.3$.

19. Slide $10637 \mathrm{~A}-1$, coordinates $28.7 \times 113.8$.

20-21. Vermutricolporites ovalis (p. 54).

Slide 10435 A-1, coordinates $26.0 \times 126.5$.

22-25. Vermutricolporites tenuicrassus n. sp. (p. 54).

22-23. Holotype. Slide $10663 \mathrm{~A}-1$, coordinates $18.0 \times 115.3$.

24-25. Slide $10637 \mathrm{~A}-1$, coordinates $25.0 \times 116.4$.

26-27. Nuxpollenites sp. (p. 54).

Slide 10558 A-1, coordinates $36.3 \times 125.7$.

28-29. Nyssapollenites pulvinus (p. 55).

Slide 10558 A-1, coordinates $23.3 \times 117.1$. 

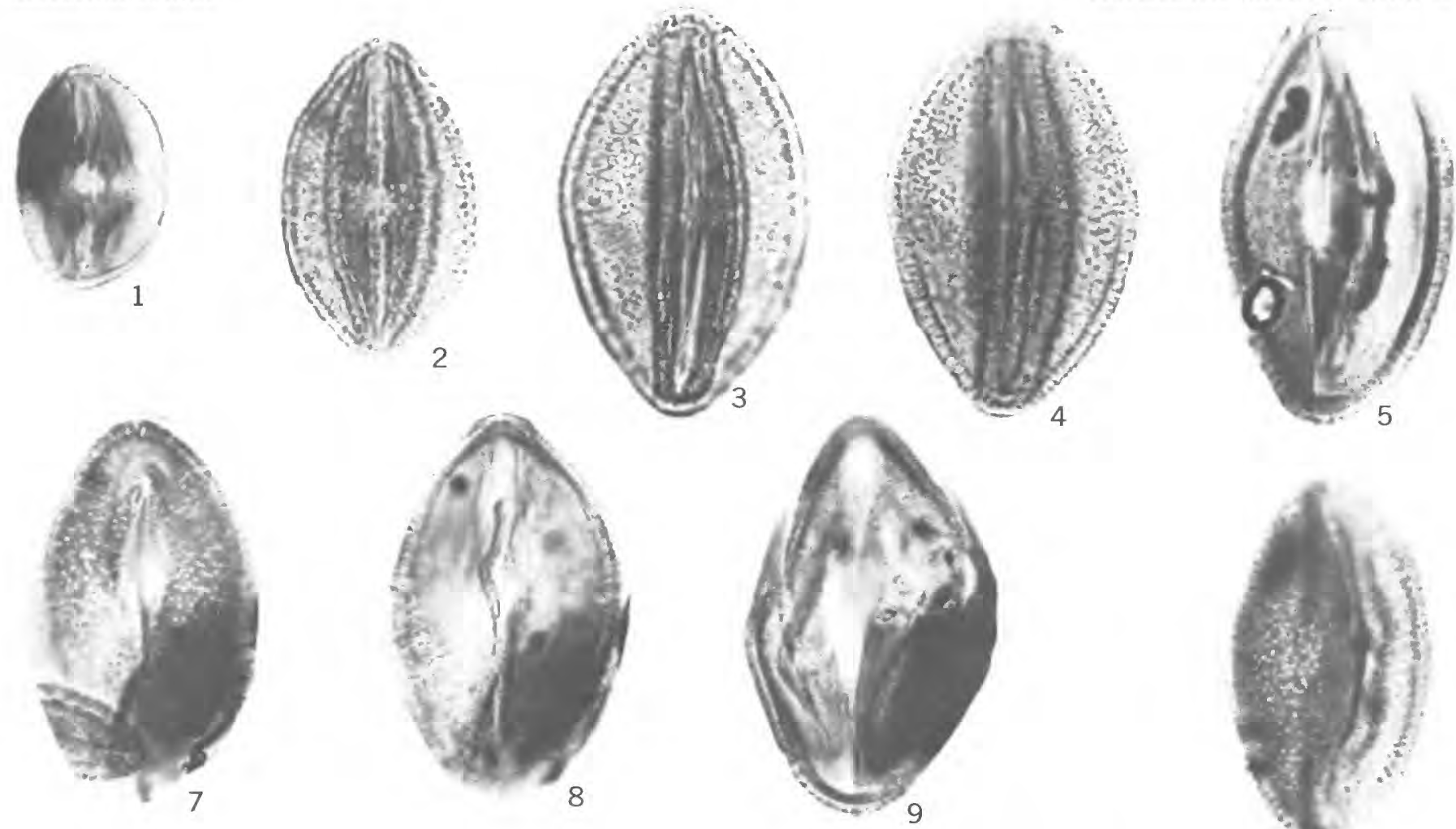

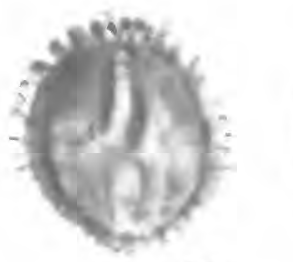

10

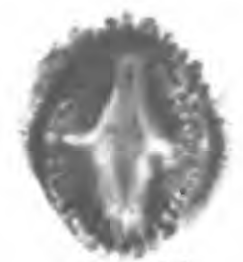

11

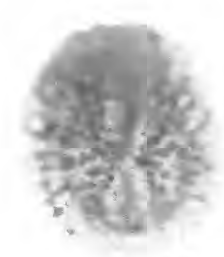

12

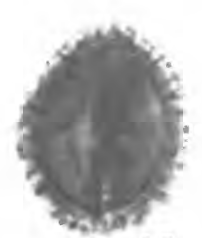

13

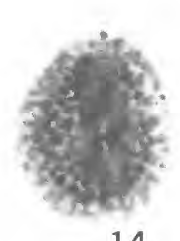

14
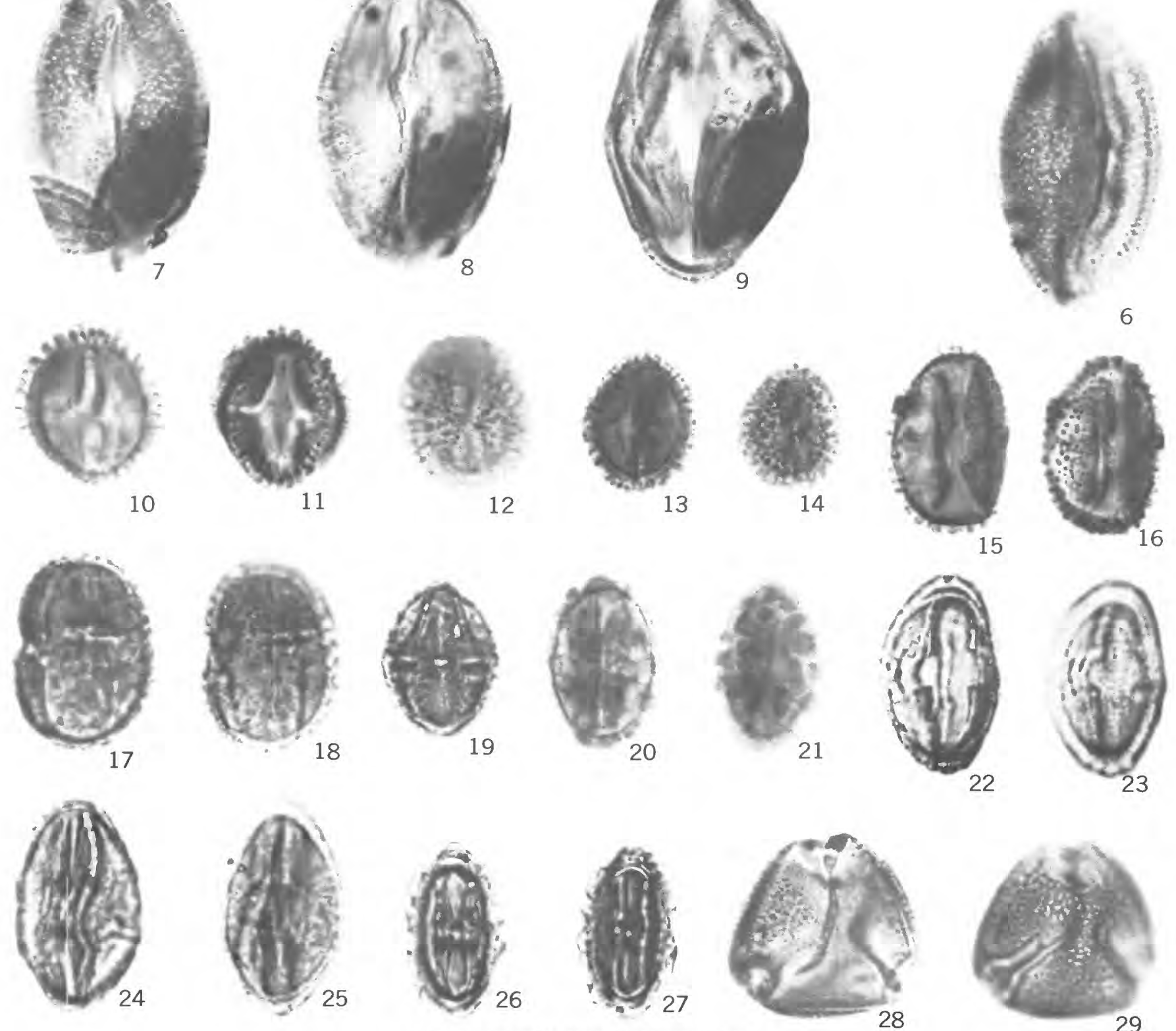

28

ANGIOSPERM POLLEN GRAINS
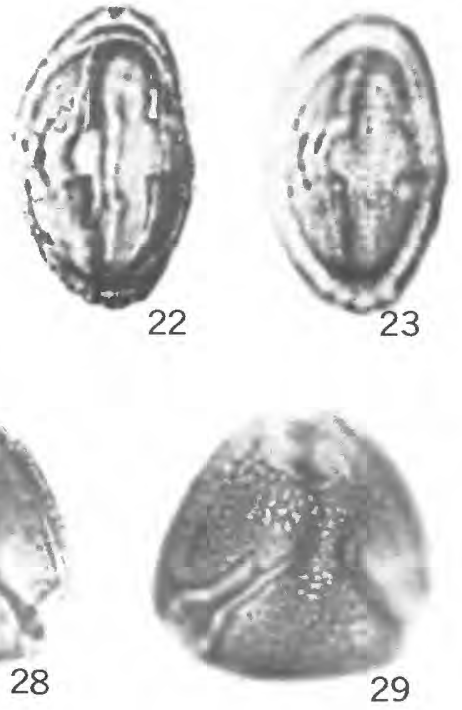
PLATE 13

[Magnification $\times 1,000$ ]

FIGURE 1. Nyssa kruschii (p. 54).

Slide $10663 \mathrm{~A}-1$, coordinates $35.6 \times 117.0$.

2-8. Rhoipites angustus n. sp. (p. 55).

2. Holotype. Slide 10553 A-1, coordinates $45.5 \times 118.0$.

3-4. Slide 14972 A-2, coordinates $22.4 \times 123.2$.

5-6. Slide 10639 A-2, coordinates $29.4 \times 125.5$.

7-8. Slide $10643 \mathrm{~A}-1$, coordinates $26.1 \times 124.8$.

9-13. Rhoipites latus n. sp. (p. 55).

9-10. Holotype. Slide $10662 \mathrm{~A}-1$, coordinates $22.1 \times 126.0$.

11-13. Slide $10662 \mathrm{~A}-1$, coordinates $21.5 \times 113.3$.

14-16. Rhoipites subprolatus n. sp. (p. 56).

14. Slide $10556 \mathrm{~A}-1$, coordinates $28.8 \times 116.6$.

15-16. Holotype. Slide $10643 \mathrm{~A}-1$, coordinates $34.4 \times 121.0$.

17-18. Horniella genuina (p. 56).

Slide 10557 A-2, coordinates $23.9 \times 114.2$.

19-20. Horniella modica (p. 56).

Slide 10515 B-3, coordinates $31.4 \times 118.6$.

21-23. Horniella sp. A (p. 56).

Slide $10558 \mathrm{~A}-1$, coordinates $34.4 \times 115.2$.

24-25. Horniella sp. (p. 57).

Slide 10637 A-1, coordinates $23.2 \times 127.6$.

26-29. Caprifoliipites incertigrandis $\mathrm{n}$. $\mathrm{sp}$. (p. 57).

26-27. Holotype. Slide $14963 \mathrm{C}-1$, coordinates $28.4 \times 119.8$.

28-29. Slide $10650 \mathrm{~A}-2$, coordinates $25.3 \times 121.1$. 

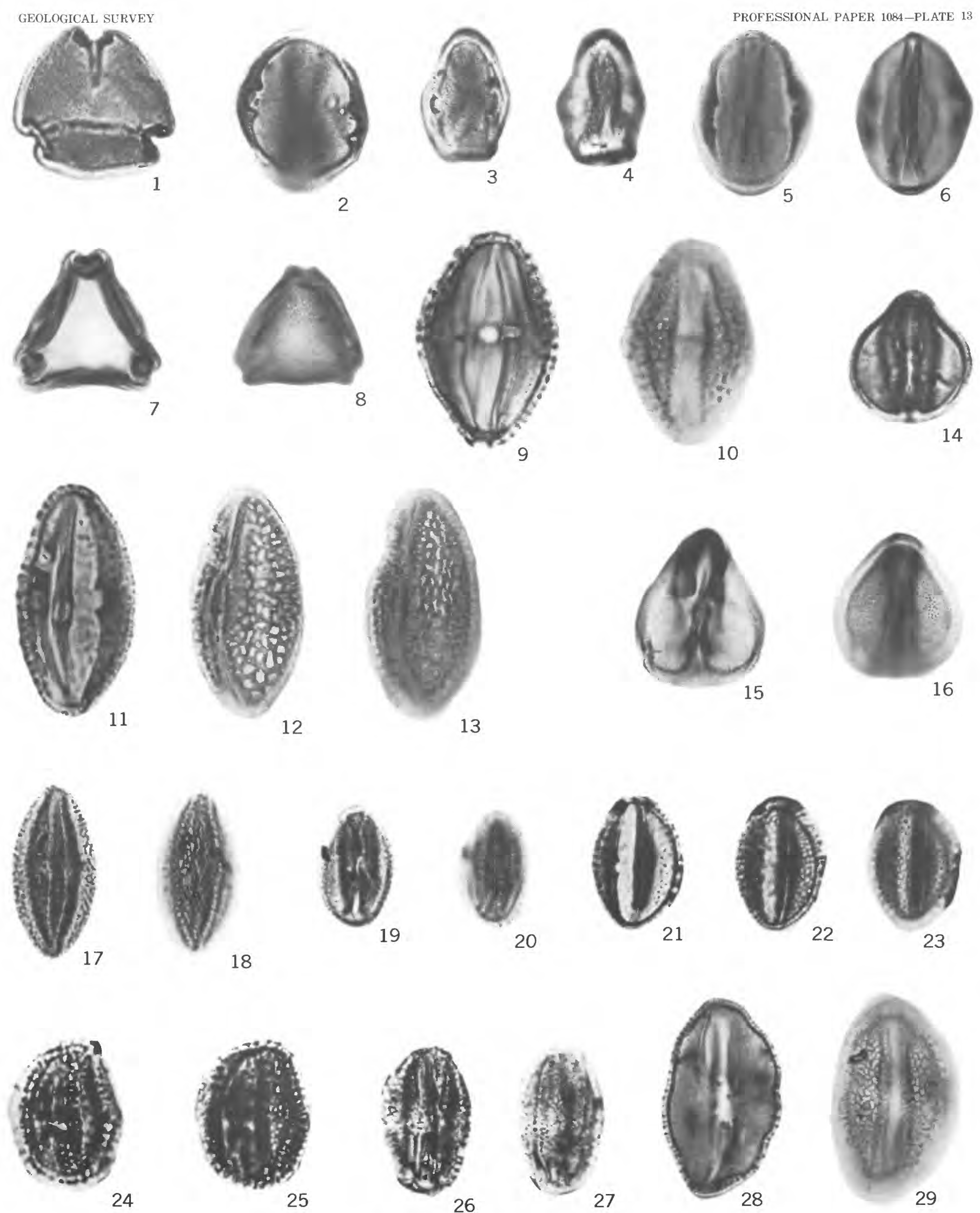

ANGIOSPERM POLLEN GRAINS 


\section{PLATE 14}

[Magnification $\times 1,000$ ]

Figures 1-2. Caprifolizpites tantulus n. sp. (p. 57).

1. Holotype. Slide 10637 A-2, coordinates $40.5 \times 122.3$.

2. Slide $10637 \mathrm{~A}-2$, coordinates $39.9 \times 113.4$.

3-6. Ailanthipites berryi (p. 57).

3-4. Slide $10556 \mathrm{~A}-1$, coordinates $39.2 \times 124.4$.

5-6. Slide 10663 A-2, coordinates $27.4 \times 114.8$.

7-8. Alangiopollis sp. (p. 58).

Slide 10556 A-1, coordinates $24.2 \times 117.3$.

9. Myrtaceidites parvus anesus (p. 58).

Slide 10864 A-2, coordinates $28.0 \times 127.2$.

10. Myrtaceidites parvus parvus (p. 58).

Slide 10627 A-2, coordinates $27.3 \times 121.7$.

11. Myrtaceidites parvus subsp. (p. 58).

Slide 10657 A-1, coordinates $29.9 \times 113.8$.

12. Cupanieidites orthoteichus (p. 58).

Slide 10643 A-2, coordinates $31.0 \times 114.3$.

13-14. Boehlensipollis hohlii (p. 59).

13. Slide $10435 \mathrm{~A}-1$, coordinates $24.9 \times 119.3$.

14. Slide $10663 \mathrm{~A}-1$, coordinates $21.9 \times 117.6$.

15. Bombacacidites nacimientoensis (p. 59).

Slide 10512 C-1, coordinates $28.5 \times 124.1$.

16. Gothanipollis cockfieldensis (p. 59).

Slide $14963 \mathrm{C}-1$, coordinates $35.9 \times 123.8$.

17-20. Intratriporopollenites stavensis $\mathrm{n}$. sp. (p. 59).

17. Holotype. Slide 10547 A-2, coordinates $28.4 \times 112.6$.

18. Slide $10557 \mathrm{~A}-2$, coordinates $28.1 \times 122.4$.

19-20. Slide $10529 \mathrm{~A}-1$, coordinates $30.0 \times 113.4$.

21-22. Tilia instructa (p. 59).

21. Slide $10531 \mathrm{~A}-1$, coordinates $26.3 \times 109.0$.

22. Slide 10627 A-2, coordinates $21.9 \times 112.3$.

23-26. Reticulataepollis reticlavata n. sp. (p. 60).

23-24. Holotype. Slide $10558 \mathrm{~A}-1$, coordinates $36.7 \times 118.8$.

25-26. Slide 10657 A-1, coordinates $29.0 \times 117.7$. 


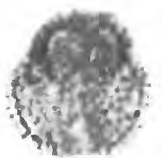

1

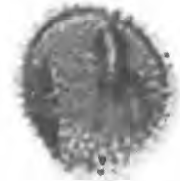

2
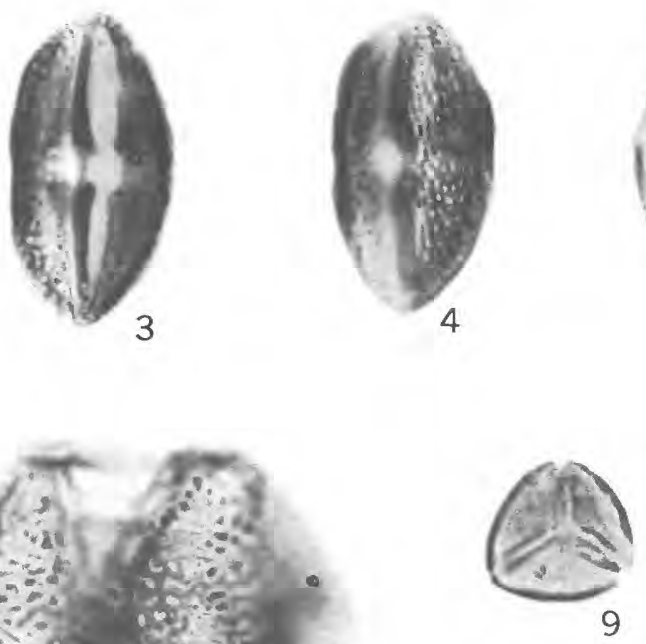

9
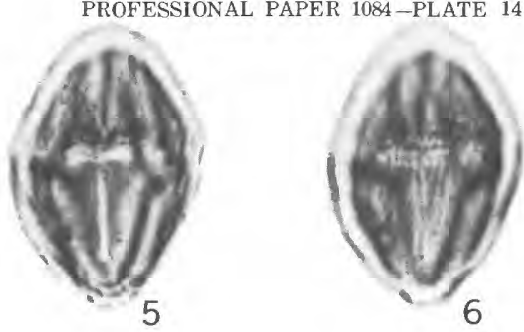

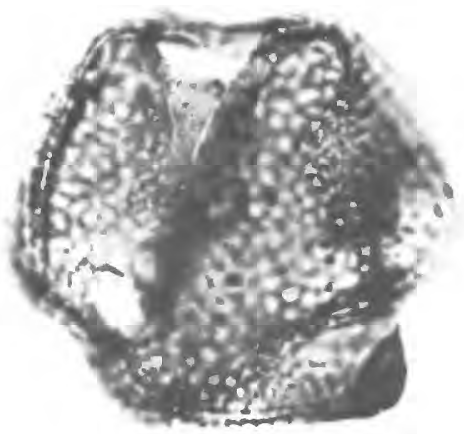

7

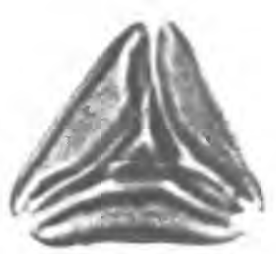

12

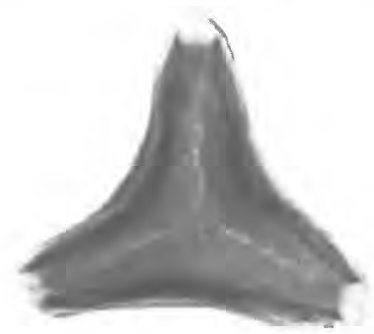

13
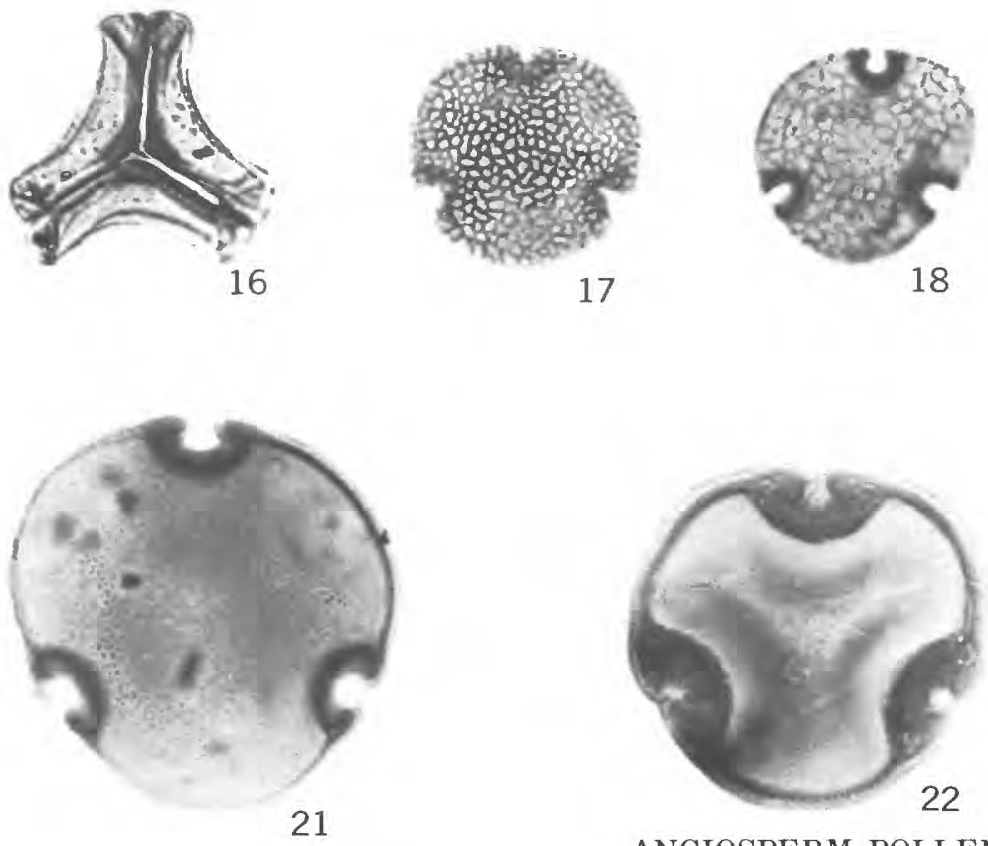

17

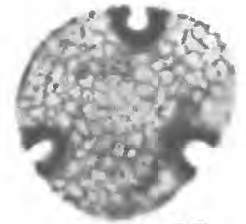

18
8
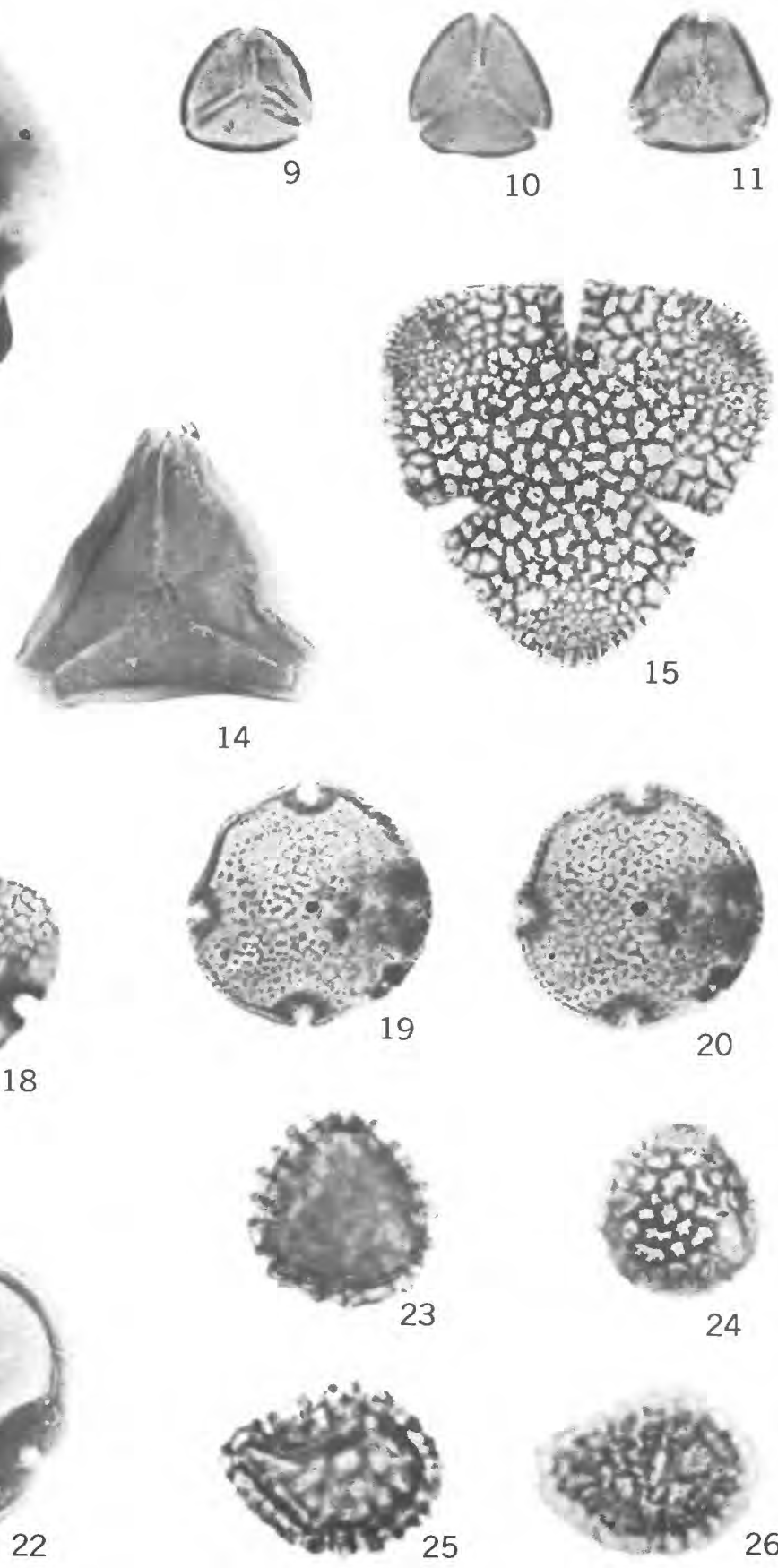

ANGIOSPERM POLLEN GRAINS 
PLATE 15

[Magnification $\times 1,000$ ]

Figures 1-4. Symplocos arcuata n. sp. (p. 60).

1-2. Holotype. Slide $10556 \mathrm{~A}-1$, coordinates $31.5 \times 114.0$.

3-4. Slide $10556 \mathrm{~A}-1$, coordinates $29.8 \times 127.5$.

5. Symplocos ceciliensis (p. 61).

Slide $10663 \mathrm{~A}-1$, coordinates $25.3 \times 114.4$.

6-9. Symplocos contracta n. sp. (p. 61).

6-7. Holotype. Slide $10556 \mathrm{~A}-1$, coordinates $28.7 \times 120.4$.

8-9. Slide $10663 \mathrm{~A}-1$, coordinates $23.3 \times 110.5$.

10-14. Symplocos gemmata n. sp. (p. 61).

10. Holotype. Slide $10653 \mathrm{~A}-1$, coordinates $20.4 \times 125.3$.

11-12. Slide 10637 A-1, coordinates $26.9 \times 122.5$.

13. A specimen with barely perceptible colpi.

Slide $10660 \mathrm{~A}-1$, coordinates $17.4 \times 118.2$.

14. Slide $10661 \mathrm{~A}-2$, coordinates $22.2 \times 110.0$.

15-16. Symplocos jacksoniana (p. 62).

Slide 14959 A-2, coordinates $36.3 \times 114.6$.

17-20. Symplocos tecta n. sp. (p. 62).

17-18. Holotype. Slide 10663 A-1, coordinates $23.3 \times 112.8$.

19-20. Slide $10663 \mathrm{~A}-1$, coordinates $18.2 \times 117.4$.

21. Symplocos? thalmannii (p. 62)

Slide $10650 \mathrm{~A}-2$, coordinates $32.8 \times 121.5$.

22. Symplocos sp. (p. 62).

Slide $10631 \mathrm{~A}-1$, coordinates $28.7 \times 111.5$.

23. Nudopollis terminalis (p. 62).

Slide 10558 A-1, coordinates $31.4 \times 113.9$. 
GEOLOGICAL SURVEY

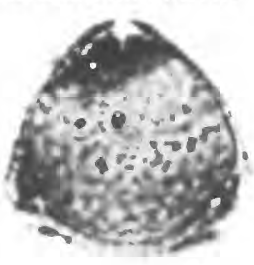

1

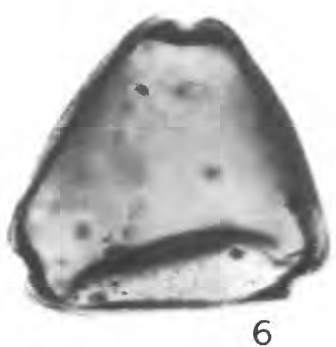

6

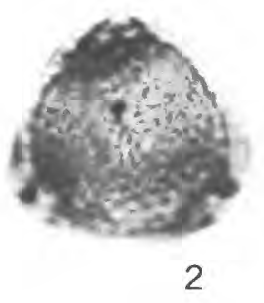

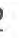
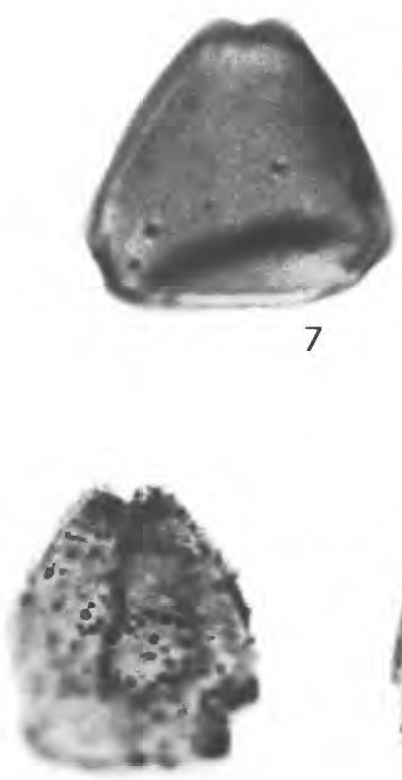

11

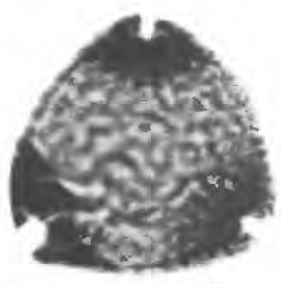

3
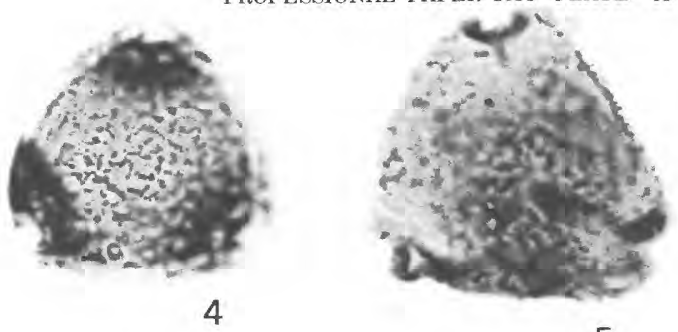

5
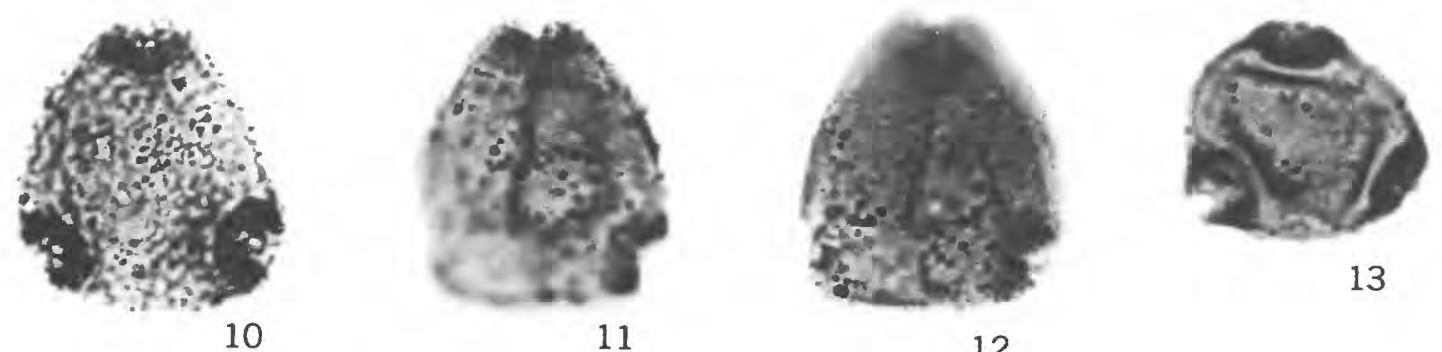

13

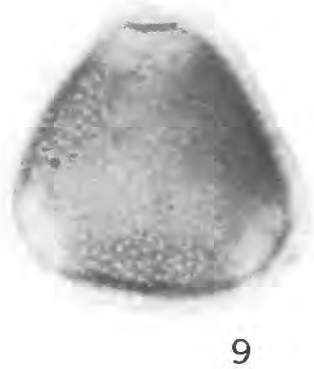

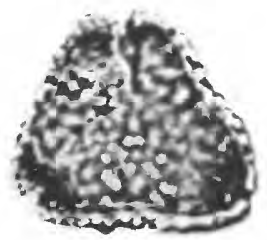

15

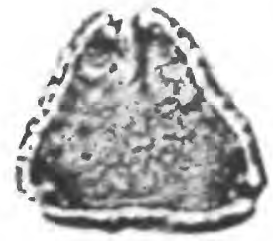

16

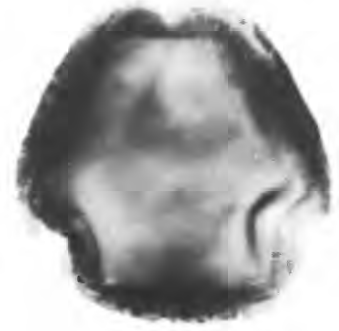

17

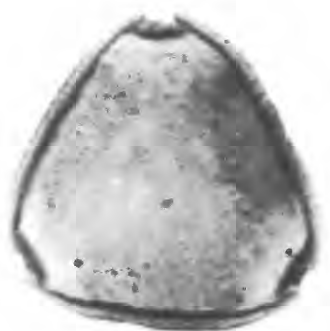

8

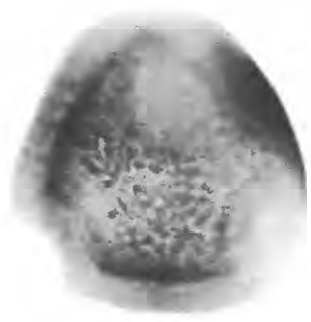

18

12

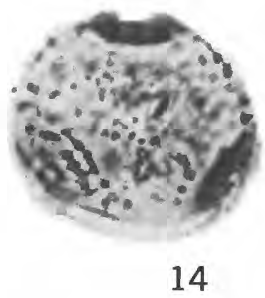

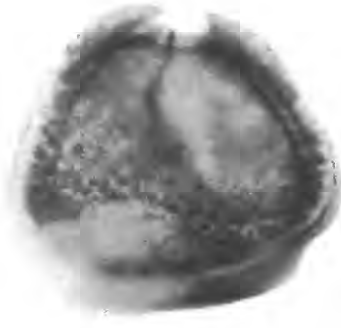

19

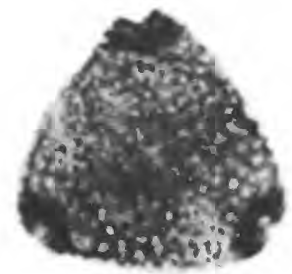

21

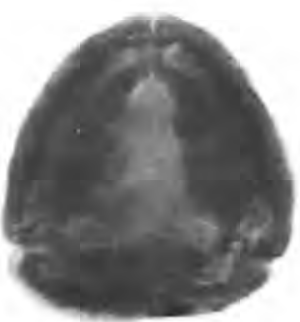

22

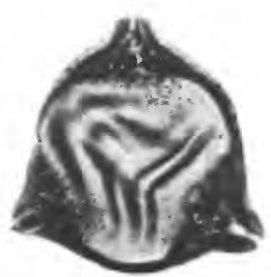

23

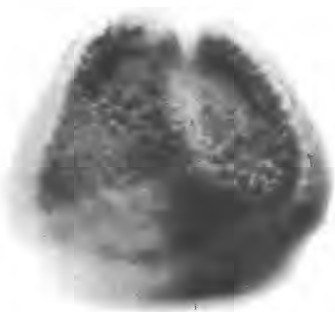

20

ANGIOSPERM POLLEN GRAINS 


\section{PLATE 16}

[Magnification $\times 1,000$ ]

Figures 1-3. Tetracolporopollenites brevis n. sp. (p. 63).

1. Holotype. Slide $10675 \mathrm{~A}-1$, coordinates $24.2 \times 120.0$.

2-3. Slide 10637 A-2, coordinates $39.5 \times 113.9$.

4. Tetracolporopollenites lesquereuxianus (p. 63).

Slide 10637 A-2, coordinates $20.9 \times 113.0$.

5. Tetracolporopollenites megadolium (p. 63).

Slide $10556 \mathrm{~A}-1$, coordinates $40.5 \times 116.3$.

6. Tetracolporopollenites $\mathrm{sp}$. (p. 64).

Slide 10650 A-2, coordinates $13.8 \times 124.9$.

7-12. Foveostephanocolporites bellus n. sp. (p. 64).

7-8. Holotype. Slide 10557 A-2, coordinates $25.0 \times 119.6$.

9-10. Slide $10637 \mathrm{~A}-2$, coordinates $31.3 \times 117.4$.

11-12. Slide $10643 \mathrm{~A}-2$, coordinates $38.9 \times 128.0$.

13-14. Ericipites aff. $E$. ericius (p. 64).

Slide $10529 \mathrm{~A}-1$, coordinates $22.2 \times 114.0$.

15-18. Ericipites redbluffensis n. sp. (p. 65).

15. Holotype. Slide $10529 \mathrm{~A}-1$, coordinates $28.5 \times 126.1$.

16-17. Slide $10529 \mathrm{~A}-1$, coordinates $31.4 \times 113.0$.

18. Slide $10529 \mathrm{~A}-1$, coordinates $35.5 \times 122.0$. 

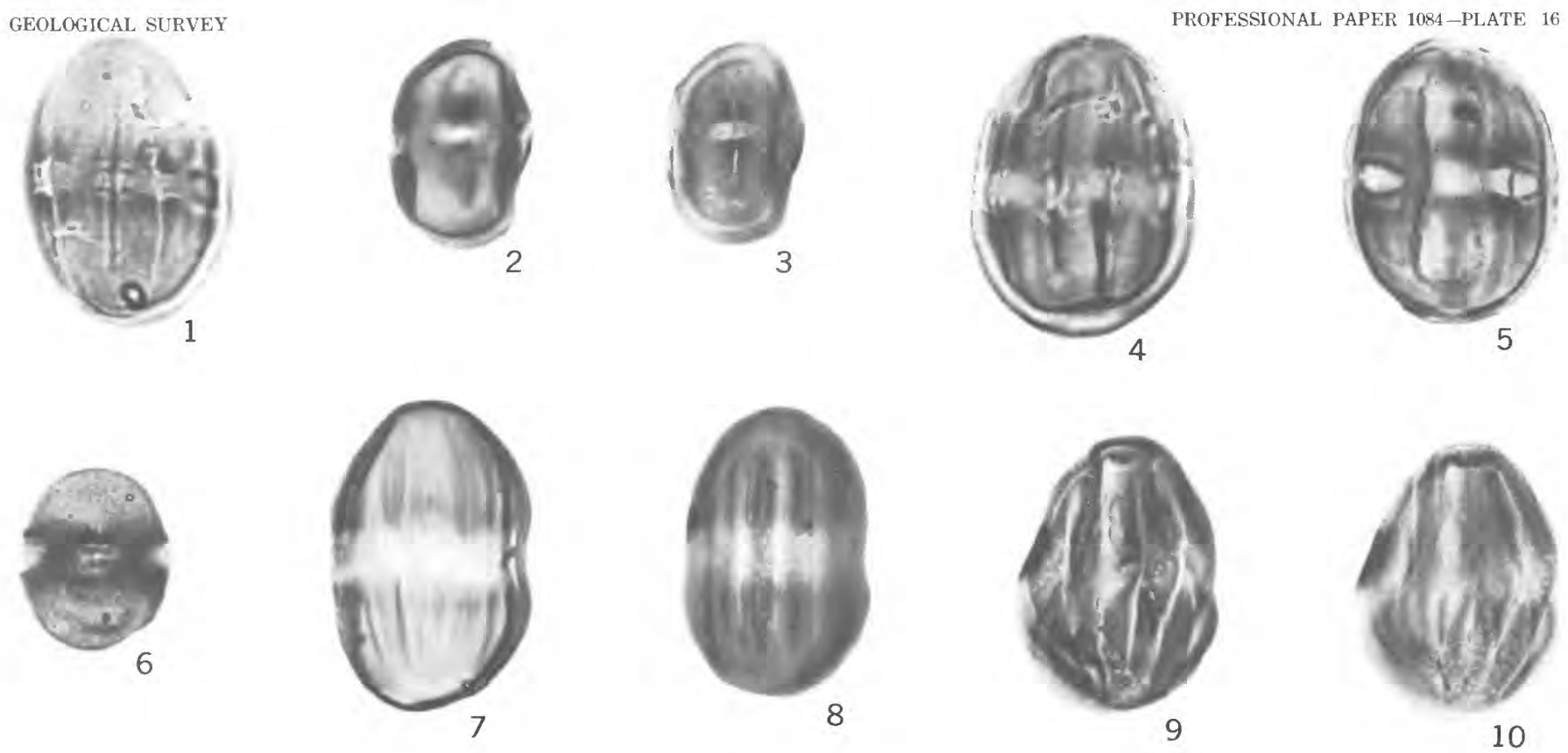

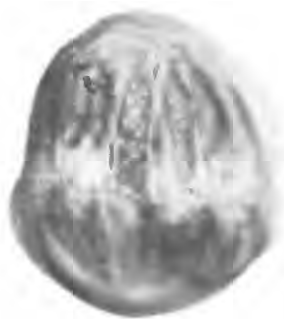

11

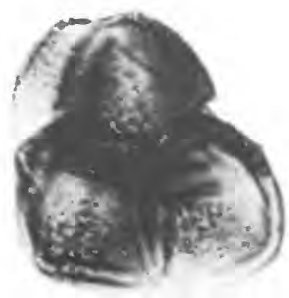

15
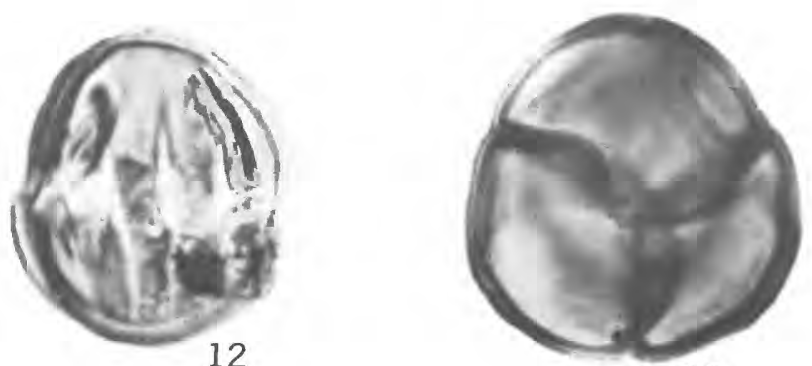

13

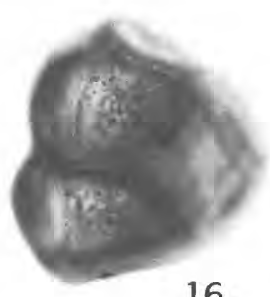

16

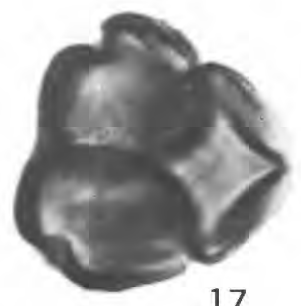

17

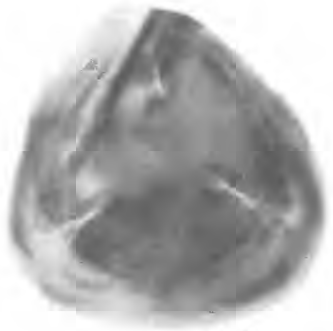

14

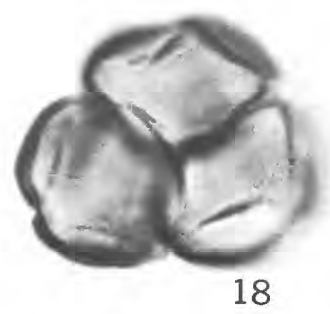

ANGIOSPERM POLLEN GRAINS 
